University of Rhode Island

DigitalCommons@URI

Open Access Dissertations

2016

\title{
Ecological Effects of Nutrient Enrichment on a Coastal Fringe Mangrove Forest
}

Brita Juliet Jessen

University of Rhode Island, brita.jessen@gmail.com

Follow this and additional works at: https://digitalcommons.uri.edu/oa_diss

\section{Recommended Citation}

Jessen, Brita Juliet, "Ecological Effects of Nutrient Enrichment on a Coastal Fringe Mangrove Forest" (2016). Open Access Dissertations. Paper 444.

https://digitalcommons.uri.edu/oa_diss/444

This Dissertation is brought to you for free and open access by DigitalCommons@URI. It has been accepted for inclusion in Open Access Dissertations by an authorized administrator of DigitalCommons@URI. For more information, please contact digitalcommons-group@uri.edu. 
ECOLOGICAL EFFECTS OF NUTRIENT ENRICHMENT ON A COASTAL FRINGE MANGROVE FOREST

BY

BRITA JULIET JESSEN

A DISSERTATION SUBMITTED IN PARTIAL FULFILLMENT OF THE

REQUIREMENTS FOR THE DEGREE OF

DOCTOR OF PHILOSOPHY

IN

OCEANOGRAPHY

UNIVERSITY OF RHODE ISLAND

2016 


\section{DOCTOR OF PHILOSOPHY DISSERTATION \\ OF}

BRITA JULIET JESSEN

\section{APPROVED:}

Dissertation Committee:

Major Professor Candace A. Oviatt

Arthur J. Gold

Charles Roman

Ariel E. Lugo

Serena Moseman-Valtierra

Nasser H. Zawia,

DEAN OF THE GRADUATE SCHOOL 


\begin{abstract}
Mangrove ecosystems are highly productive coastal wetlands that connect tropical terrestrial and marine systems. Increasing human populations and land use changes are enhancing nutrient loading to tropical coastlines, potentially leading to eutrophic conditions for marine systems. The carbon (C) cycle is critical for mangrove forest structure, function, and resilience under environmental change. Increasing trends of nutrient enrichment in tropical coastal waters may have an effect on organic C mineralization by alleviating nutrient limitation of the heterotrophic microbial community, which may lead to a loss of within-stand carbon sequestration. To better understand and predict the consequences of increased nutrient input, a fertilization study within a fringe mangrove system in southeast Puerto Rico was established to mimic highnitrogen agriculture runoff (N:P ratio of 50:1) or urban runoff with higher phosphorus ( $\mathrm{N}: \mathrm{P}$ ratio of $16: 1$ ) for an annual loading rate of $70 \mathrm{~g} \mathrm{~N} \mathrm{~m}^{-2} \mathrm{y}^{-1}$ and 3.1 or $9.7 \mathrm{~g} \mathrm{P} \mathrm{m}^{-2} \mathrm{y}^{-1}$. Bi-weekly pulses of fertilization began in October 2011 and continued for two years.

Chapter 1 investigates nutrient enrichment effect on organic carbon mineralization by sediment microbial respiration rates and above- and below-ground litter decomposition. Neither of the fertilization scenarios had an effect on any of the $\mathrm{C}$ mineralization processes compared with ambient conditions in this two-year study. Sediment respiration rates ranged from 0.54 to $2.63 \mu \mathrm{mol} \mathrm{CO}_{2} \mathrm{~m}^{-}{ }^{2} \mathrm{~s}^{-1}$. Above-ground litter was calculated to completely decompose within 38 to 220 days by microbial activity alone. This work agrees with previous studies of nutrient enrichment and organic C decomposition rates in mangrove systems, yet differences in the reported values of $\mathrm{C}$
\end{abstract}


mineralization between sites suggest that forest type, environmental conditions, and location may play a substantial role in mangrove C dynamics.

Chapter 2 evaluates above-ground production (tree biomass and litter production) in response to nutrient enrichment. Mangrove tree response was characterized by aboveground wood production and litterfall input. Basal area ranged from 17.1 to $32.7 \mathrm{~m}^{-2} \mathrm{~m}^{-2}$. Above-ground biomass (wood and foliage) ranged from 3.9 to $15.4 \mathrm{~kg}$ dry mass $\mathrm{m}^{-2}$. Mangrove above-ground growth was highly variable and was not affected by nutrient treatment. Litterfall was strongly seasonal, with higher rates associated with the start of the rainy season in late summer. Total litterfall for this fringe mangrove ranged from 1061 to $1217 \mathrm{~g}$ dry mass $\mathrm{m}^{-2} \mathrm{y}^{-1}$, which was on the higher range of neo-tropical fringe mangroves. Total litter production was not affected by nutrient treatment, but agriculture treatment (high $\mathrm{N}: \mathrm{P}$ ) enhanced leaf and stipule production $\left(\mathrm{p}=0.04\right.$ and $2.2 \mathrm{e}^{-06}$, respectively). These results suggest that two years of high $\mathrm{N}: \mathrm{P}$ nutrient addition results in a small positive effect for above-ground production within a fringe mangrove, and that litterfall may be a more sensitive response than above-ground biomass for a short-term (two years) assessment. Considering the different effects to mangrove production by the nutrient enrichment regimes (high vs. intermediate N:P loading), further work is needed to assess $\mathrm{N}$ and $\mathrm{P}$ interactions that may affect above-ground mangrove production.

In Chapter 3, a one-time spike of ${ }^{15} \mathrm{~N}$ stable isotope tracer was added to ambient (receiving local channel water) and chronically nutrient enriched (receiving $70 \mathrm{~g} \mathrm{~N} \mathrm{~m}^{-2} \mathrm{y}^{-}$ ${ }^{1}$ and $9.7 \mathrm{~g} \mathrm{P} \mathrm{m}^{-2} \mathrm{y}^{-1}$ for 21 to 24 months) sites within a coastal fringe mangrove forest in southeastern Puerto Rico to determine if nutrient enrichment was being retained in the mangrove ecosystem, and to identify mangrove $\mathrm{N}$ sinks. Measurements for ${ }^{15} \mathrm{~N}$ retention 
occurred at 1 month, 3 months, and 10 months after the initial spike. ${ }^{15} \mathrm{~N}$ tracer was recovered in all components (mangrove foliage, standing litter, surface sediment, and fine roots) within ambient and fertilized sites. The highest proportion of tracer retention (28 to $59 \%$ under ambient conditions and 14 to $28 \%$ under nutrient enriched conditions) occurred in the organic layer of the forest floor (standing litter, surface sediment, and surficial fine roots). ${ }^{15} \mathrm{~N}$ retention within the mangrove canopy represented the smallest $\mathrm{N}$ sink, although foliar $\delta^{15} \mathrm{~N}$ continued to increase throughout the measurement period. Tracer retention within the organic layer of the forest floor indicates strong recycling and retention of nutrients that supports a highly-productive system in an oligotrophic marine environment. Chronically nutrient enriched sites retained more ${ }^{15} \mathrm{~N}$ tracer than ambient sites, but a smaller proportion of the applied ${ }^{15} \mathrm{~N}$ fertilizer, suggesting the capacity of nutrient retention had been exceeded by the added nutrient load. The culmination of this work suggests resilience of mangrove ecosystem function within the first two years of nutrient enrichment. 


\section{ACKNOWLEDGMENTS}

This project was carried out with help from a devoted and generous team of scientists, managers, students, and friends and family members who were brave and curious enough to traverse the mangal.

Students, research assistants, and volunteers were invaluable members of the research team. I thank Jessica Foley, Ryan Rossi, Chelsea Duball, Ishamari Colon, Sandra Schleier, Laura Almodovar, Juan Alvarez Rosario, Johanna Nifosi, Laura Caicedo-Quiroga, David Johnson, Lindsey Fields, Amy Van Keuren, Carol Goranson, Vuarnelle Urena, Ryan Quinn, John Jessen, Adam O’Donnell, and Dr. Autumn Oczkowski for their fortitude and good humor in the field. Nicholas Koester and Alicia Kauffman helped with laboratory analysis in Rhode Island. Francesco Peri helped design and build sampling equipment.

The Jobos Bay National Estuarine Research Reserve was home base for our endeavors. I am grateful to Carmen Gonzalez Sifonte, Angel Dieppa, and the staff at the Reserve as well as Puerto Rico Department of Natural Resources for enabling our field and laboratory work, and providing us a home away from home.

Scientists at the International Institute of Tropical Forestry and the University of Puerto Rico were critical to the development and success of this work. I am grateful to Dr. Ariel Lugo, Dr. Ernesto Medina and Dr. Elvira Cuevas for their expert opinions throughout the development of this project. Maysaa Ittayem, Edwin Lopez, and Mary Sanchez assisted with reagent preparation and provided laboratory access and counsel.

When it was time to take a break from work, our time in Puerto Rico was enriched by wonderful personal connections. Dr. Juan Gonzalez Lagoa enhanced our knowledge 
of the natural history of Puerto Rico, and generously supported undergraduate students on this project. While our heads were focused on research, our hearts were fulfilled by caring for the satos who wandered into our world. Mary Eldergill and Dr. Hector Martínez were our guides for street dog rehabilitation and rescue, in exchange for some conversation on the current status of mangrove ecology.

I thank workers with the U.S. Environmental Protection Agency/Atlantic Ecology Division in Narragansett, RI for their expertise and accommodation. My proficiency in instrument use and data interpretation expanded under the guidance of Dr. Autumn Oczkowski, Alana Hanson, Dr. Richard McKinney, Dr. Cathleen Wigand, Dr. Elizabeth Watson, and Dr. Jason Greer.

My life-long gratitude goes to my two major professors and mentors, Scott Nixon and Candace Oviatt. Dr. Nixon picked the horse, and Dr. Oviatt saw her through. I am likewise thankful for my committee of brilliant teachers - Drs. Arthur Gold, Charles Roman, Ariel Lugo, and Serena Moseman-Valtierra.

I could fill another ten pages with names of family and friends who led me through this long stretch. Drs. Kiersten Curti, J. Stanley Cobb, and Megan O'Connor top the long, heartfelt list. The most generous and devoted friend has been Adam O'Donnell, who came with me to the north woods so I could complete this work and continue onward together.

This work was funded by grants from the U.S. Forest Service, the National Oceanic and Atmospheric Association - National Estuarine Research Reserve Graduate Fellowship, The Nature Conservancy Marine Initiative, Rhode Island and Puerto Rico Sea Grant programs, and the University of Rhode Island's Coastal Institute. 


\section{Dedication}

\section{I dedicate this work to my parents and mentor,}

H.N.S., J.M.J, and S.W.N.

All future work will be in honor of C.A.O. and the future he belongs to. 


\section{PREFACE}

This dissertation is written in the manuscript format specified by the University of Rhode Island Graduate School. The body of this dissertation has been divided into three chapters corresponding to three manuscripts, each formatted for a specific journal. Chapter 1 is written for Hydrobiologia with Candace Oviatt, Cathleen Wigand, David Johnson, Ryann Rossi, Chelsea Duball, and Scott Nixon as coauthors. Chapter 2 is written for Aquatic Botany with Candace Oviatt, Ariel Lugo, Ernesto Medina, Jessica Foley, Megan O’Connor, Susanne Hoeppner, and Scott Nixon as coauthors. Chapter 3 is written for the Journal of Experimental Marine Biology and Ecology with Arthur Gold, Autumn Oczkowski, Rick McKinney, Kenneth Miller, and Ryan Quinn as coauthors. These manuscripts will be submitted for peer review and publication upon completion of this dissertation. The supplement information provided in Appendix A includes additional data that may be referred to in the text. Appendix B contains original litterfall data. Appendix C contains original stable isotope and nutrient content data. At the end of the dissertation is a complete bibliography. 


\section{TABLE OF CONTENTS}

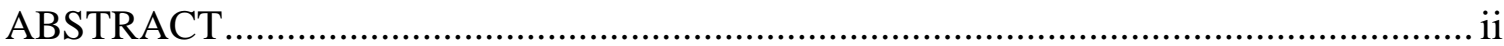

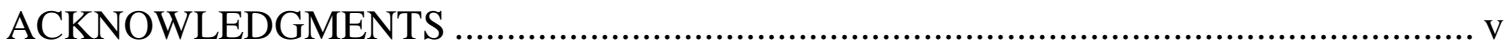

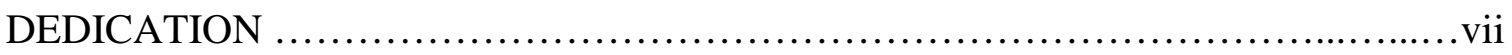

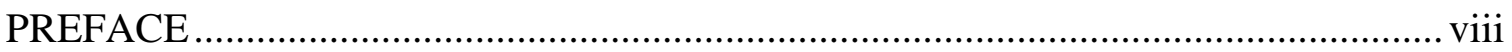

TABLE OF CONTENTS ................................................................................... ix

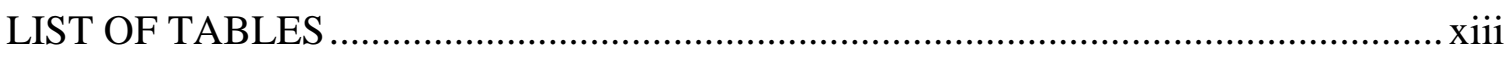

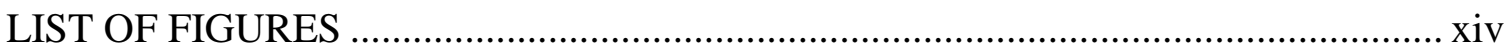

Chapter 1: BENTHIC RESPIRATION AND LEAF LITTER DEGRADATION UNDER NUTRIENT LOADING SCENARIOS IN A FRINGE RHIZOPHORA MANGLE

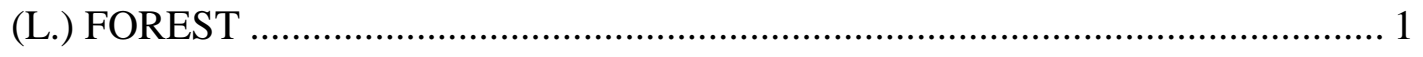

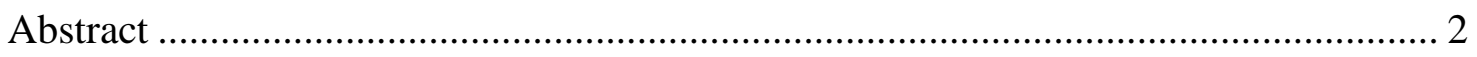

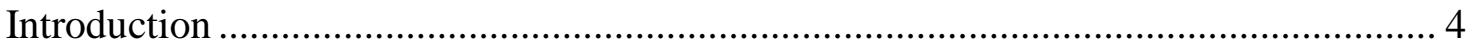

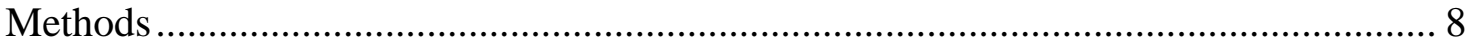

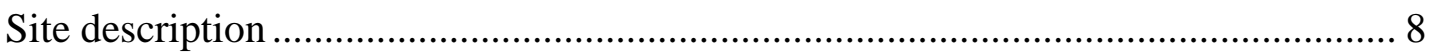

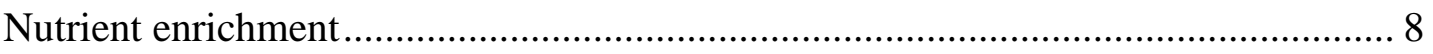

Sediment characterization ............................................................................. 9

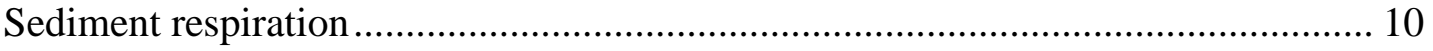

Above-ground Litter Decomposition .................................................................... 11

Below-ground leaf decomposition ......................................................................... 14

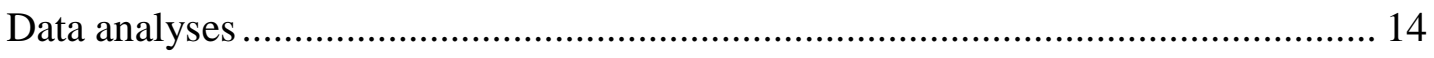




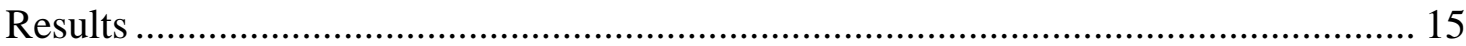

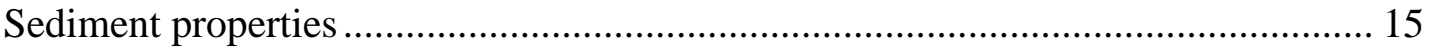

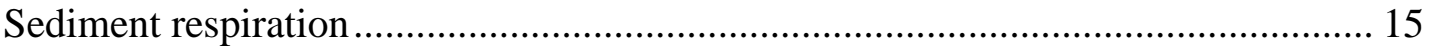

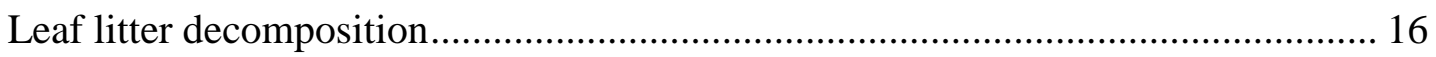

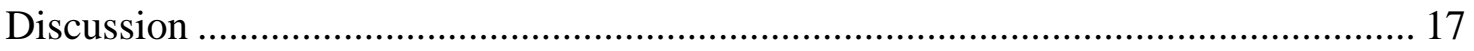

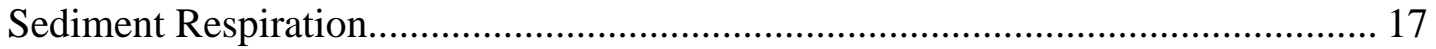

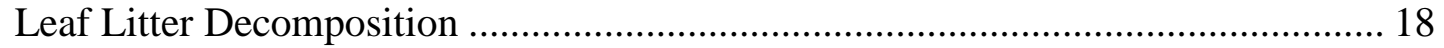

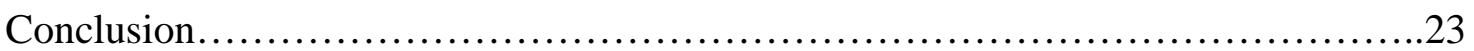

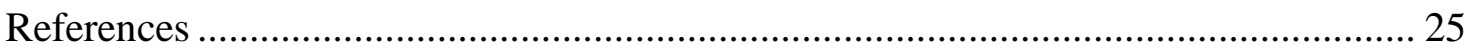

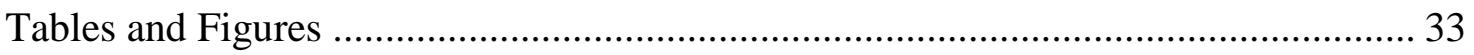

\section{Chapter 2: EFFECT OF NUTRIENT ENRICHMENT ON ABOVE-GROUND}

PRODUCTION IN A PUERTO RICAN MANGROVE FOREST ........................ 43

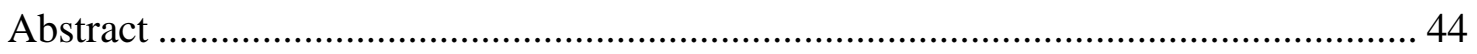

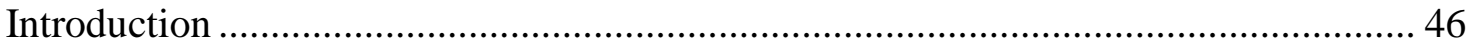

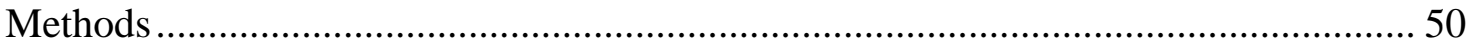

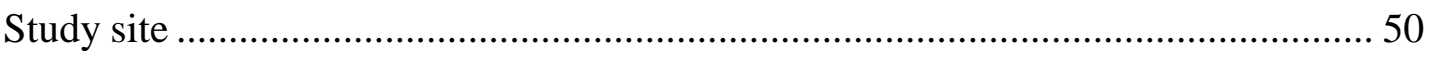

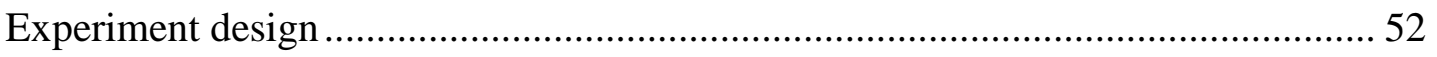

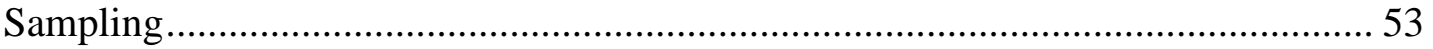

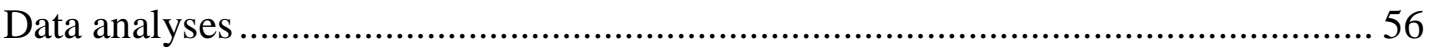

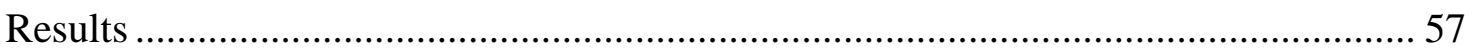


Discussion

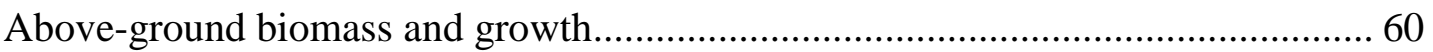

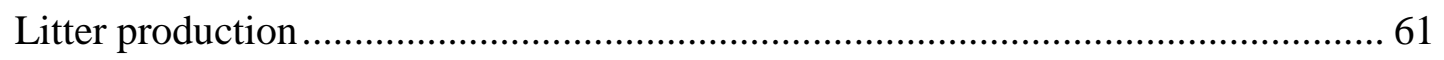

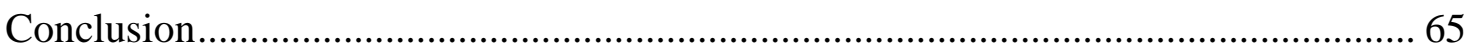

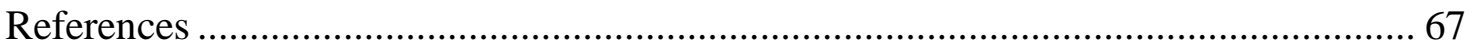

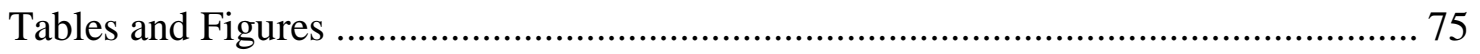

Chapter 3: NUTRIENT UPTAKE AND RETENTION WITHIN A FRINGE

MANGROVE STAND UNDER DIFFERENT NUTRIENT LOADS ................... 85

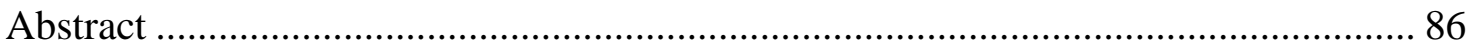

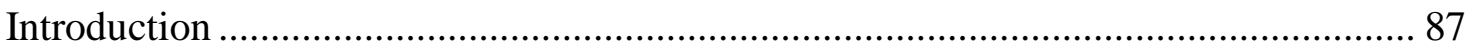

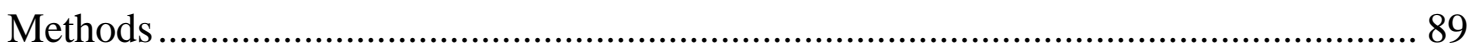

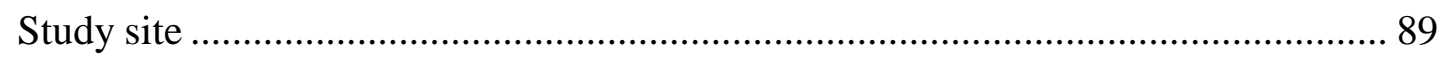

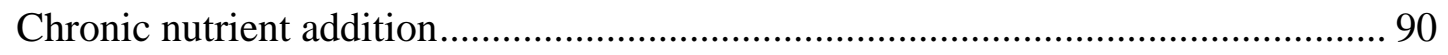

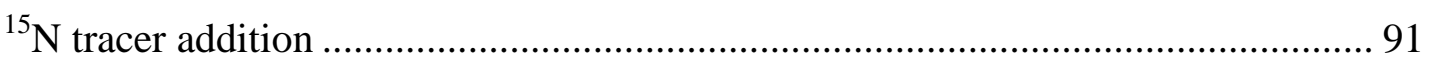

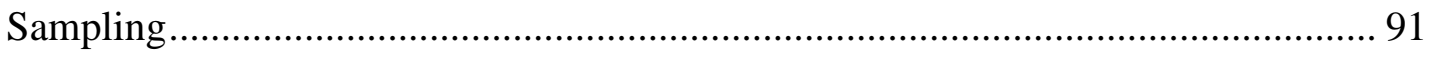

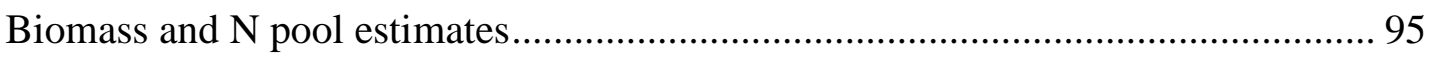

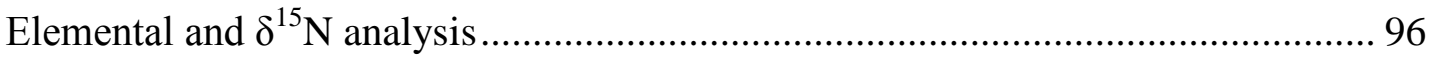

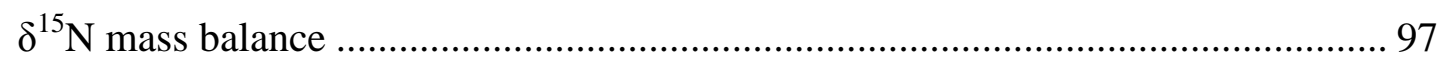

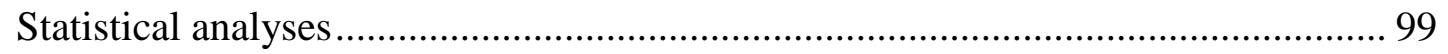

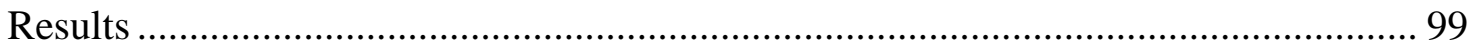




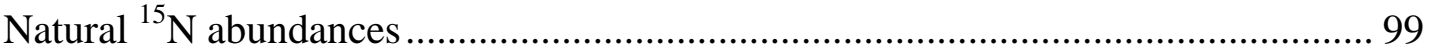

Ecosystem N pools .................................................................................... 100

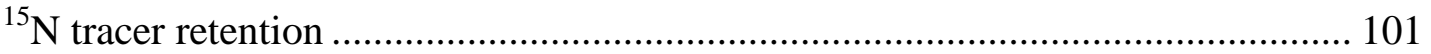

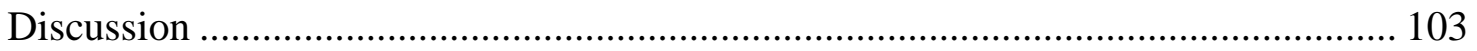

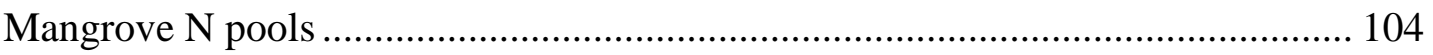

Effect of nutrient enrichment on $\mathrm{N}$ retention ..................................................... 105

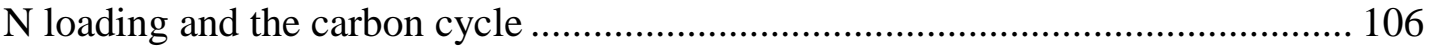

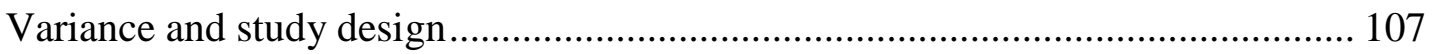

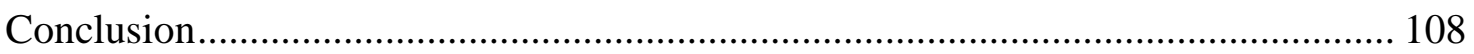

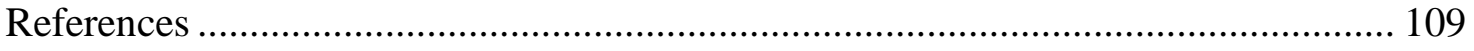

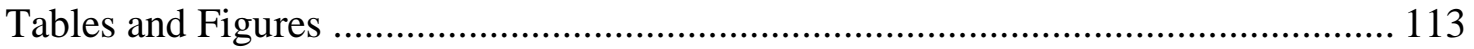

Appendix A: Supplemental tables and figures..................................................... 122

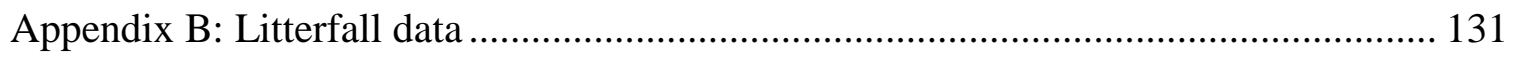

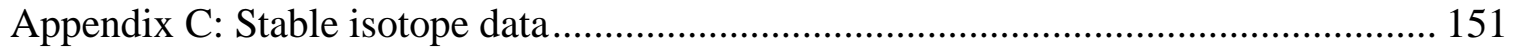

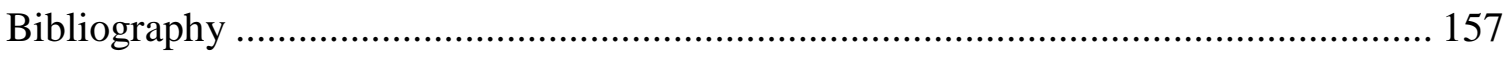




\section{LIST OF TABLES}

\section{Chapter 1}

Table 1-1. Edaphic characterization of experimental quadrats.................................... 34

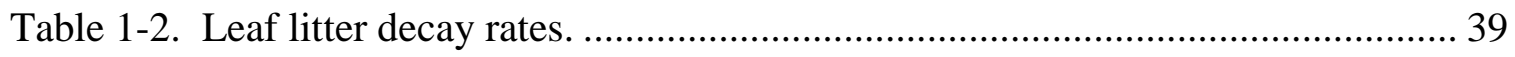

Table 1-3. Reported values of litter decomposition from mangrove systems across the

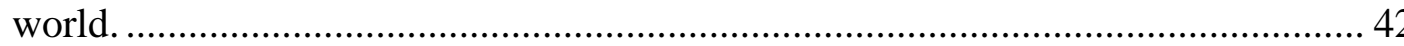

\section{Chapter 2}

Table 2-1. Stand characterization of the fringe mangrove site ................................... 76

Table 2-2. Tree characterization of the fringe mangrove site ..................................... 77

Table 2-3. Results of two-factor repeated measures analyses of variance. .................... 80

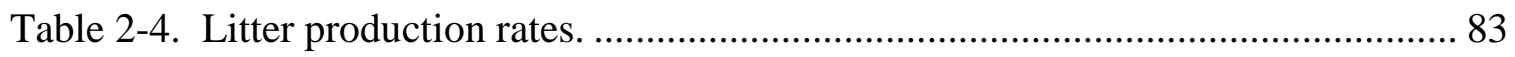

Table 2-5. Past field studies of experimental nutrient enrichment in mangroves............ 80

\section{Chapter 3}

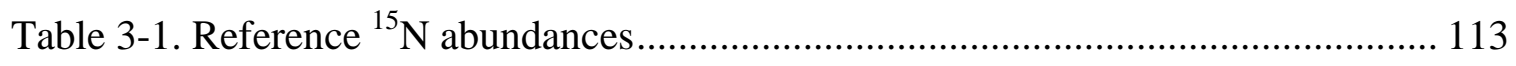

Table 3-2. Mass and N content of measured ecosystem components........................... 114

Table 3-3. Mass and N content of measured ecosystem components........................... 115

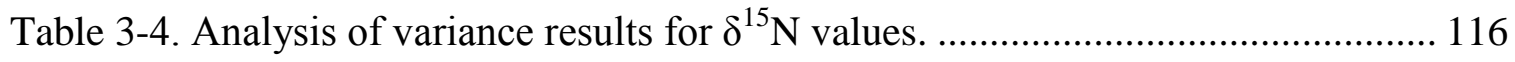

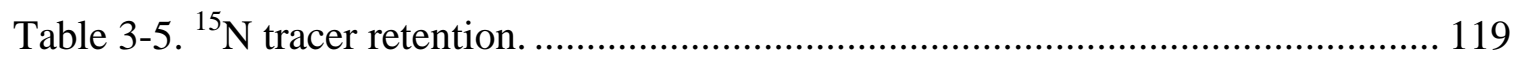

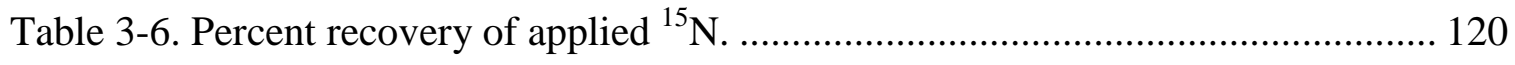




\section{LIST OF FIGURES}

\section{Chapter 1}

Figure 1-1. Satellite image of Jobos Bay, located in southeastern Puerto Rico. 33

Figure 1-2. Sediment bulk density and percent organic content.................................. 35

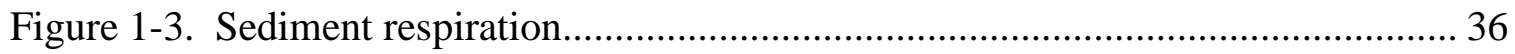

Figure 1-4. Percent mass remaining for below-ground mangrove leaf litter.................. 37

Figure 1-5. Leaf litter decomposition under three nutrient conditions .......................... 38

Figure 1-6. Molar C:N ratio of decaying leaf litter.................................................... 40

Figure 1-7. Percent mass remaining for below-ground mangrove leaf litter.................. 41

\section{Chapter 2}

Figure 2-1. Satellite image of Jobos Bay, located in southeastern Puerto Rico.. ........... 75

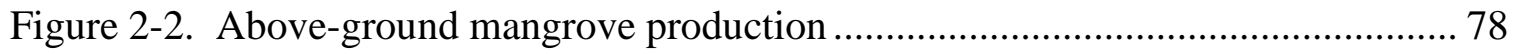

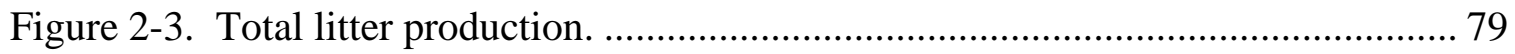

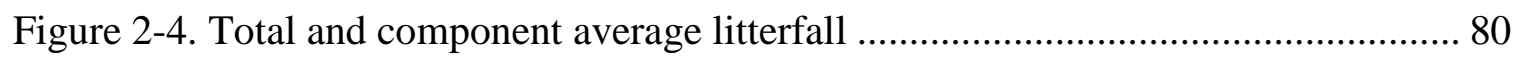

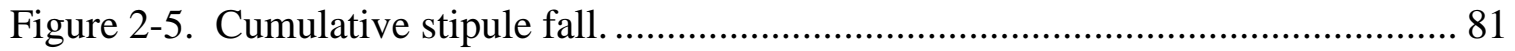

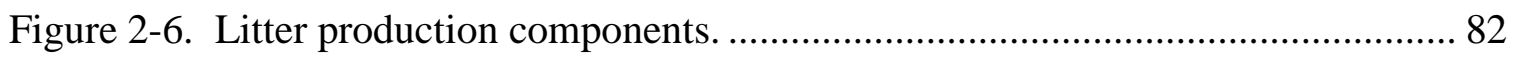

Chapter 3

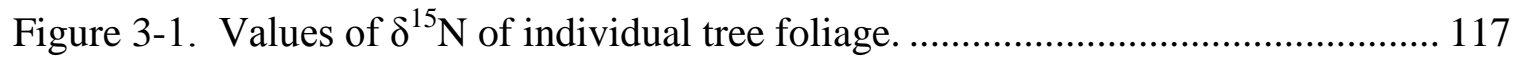

Figure 3-2. Frequency of $\delta^{15} \mathrm{~N}$ value categories from tree foliage. .............................. 118

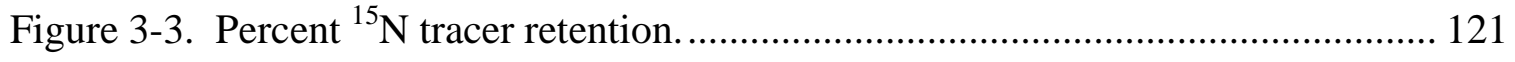




\section{Chapter 1}

\section{BENTHIC RESPIRATION AND LITTER DEGRADATION UNDER NUTRIENT LOADING SCENARIOS IN A FRINGE RHIZOPHORA MANGLE (L.) FOREST}

To be submitted to Hydrobiologia

Brita J. Jessen ${ }^{1}$, Candace Oviatt ${ }^{1}$, Cathleen Wigand ${ }^{2}$, Ryann Rossi ${ }^{3}$, Chelsea Duball ${ }^{4}$, David Johnson ${ }^{5}$, and Scott Nixon ${ }^{1 \dagger}$

1Graduate School of Oceanography; University of Rhode Island; 215 South Ferry Road; Narragansett, RI 02882 USA

${ }^{2}$ U. S. EPA Atlantic Ecology Division; 27 Tarzwell Drive; Narragansett, RI 02882

${ }^{3}$ Department of Applied Ecology; North Carolina State University; Raleigh, NC 27695

${ }^{4}$ Natural Resources Science; University of Rhode Island; Kingston, RI 02882

${ }^{5}$ Biological Sciences; Virginia Institute of Marine Science; 1208 Greate Rd, Gloucester Point, VA 23062

${ }^{\dagger}$ Deceased 


\title{
BENTHIC RESPIRATION AND LITTER DEGRADATION UNDER NUTRIENT LOADING SCENARIOS IN A FRINGE RHIZOPHORA MANGLE (L.) FOREST
}

\begin{abstract}
The carbon (C) cycle is critical for mangrove forest structure, function, and resilience under environmental change. Increasing trends of nutrient enrichment in tropical coastal waters may have an effect on organic $\mathrm{C}$ mineralization by alleviating nutrient limitation of the heterotrophic microbial community, which may lead to a loss of within-stand carbon sequestration. For this study, I enriched a coastal fringe Rhizophora mangle (L.) mangrove system for two years with two fertilizer regimes to mimic highnitrogen agriculture runoff (N:P ratio of 50:1) or urban runoff with higher phosphorus ( $\mathrm{N}: \mathrm{P}$ ratio of $16: 1$ ) for an annual loading rate of $70 \mathrm{~g} \mathrm{~N} \mathrm{~m}^{-2} \mathrm{y}^{-1}$ and 3.1 or $9.7 \mathrm{~g} \mathrm{P} \mathrm{m}^{-2} \mathrm{y}^{-1}$. Carbon mineralization was measured by sediment microbial respiration rates and aboveand below-ground litter decomposition. Neither of the fertilization scenarios had an effect on any of the $\mathrm{C}$ mineralization processes compared with ambient conditions in this two-year study. Sediment respiration rates ranged from 0.54 to $2.63 \mu \mathrm{mol} \mathrm{CO} \mathrm{CO}^{-2} \mathrm{~s}^{-1}$ and was consistent across measurement periods. Time to 50\% decay of above-ground leaf litter ranged from 61 to 110 days (average 79 days) by microbial activity alone. Below-ground leaf litter material was fully decomposed by 22 months after burial. Nutrient enrichment effects on organic C mineralization appear to be constrained by the highly refractory mangrove material. Slow C mineralization is an important mechanism of organic peat formation and nutrient conservation within the mangrove wetland. Differences in the reported values of $\mathrm{C}$ mineralization between sites suggest that forest
\end{abstract}


type, environmental conditions, and location may play a substantial role in mangrove C dynamics. 


\section{INTRODUCTION}

Mangrove ecosystems are often attributed for providing services such as storm buffering (Das \& Vincent, 2009), wastewater depuration (Corredor \& Morell, 1994), sea level rise resilience (McKee et al., 2007), enhancement of secondary production (Mumby et al., 2004), and carbon sequestration (Bouillon et al., 2008; Donato et al., 2011). Each of these processes is directly linked to organic matter production and turnover rates within the mangrove system; thus the mechanisms and driving factors of organic matter production, decomposition, and retention are necessary elements for understanding mangrove ecosystem services. The mangrove habitat - ranging from warm temperate to tropical coastlines - is subject to increasing anthropogenic nutrient (nitrogen, $\mathrm{N}$ and phosphorus, P) loading rates due to rising human populations, urban development, and changing land use practices (Corredor et al., 1999; Downing et al., 1999; Nixon et al., 2007). Globally, regions with the greatest increase of inorganic nutrient input to coastal waters (over $500 \mathrm{~kg}$ DIN km-2 y-1) include densely populated areas of the Indian Ocean, southwest Pacific, and to a smaller extent the Caribbean Sea (Deegan et al., 2012) where mangroves dominate the vegetated coastline. While temperate coastal systems are considered to be primarily $\mathrm{N}$-limited, tropical coastal ecosystems have been found to be either $\mathrm{N}$ and/or $\mathrm{P}$ limited depending on factors such as sediment delivery, $\mathrm{N}$-fixing microbial activity, and sediment cation exchange capacity (Corredor et al., 1999; Howarth \& Marino, 2006; Reef et al., 2010). The rapid anthropogenic enhancement of biologically-available inorganic nutrients (Howarth, 2008) combined with the central importance of the carbon cycle for coastal ecosystem function drives the need for an 
understanding of organic carbon processes under enriched nutrient conditions in mangrove systems.

The main source of new organic material within the mangrove habitat is high primary production rates of mangrove trees (Bouillon et al., 2008; Kristensen et al., 2008). The evolutionary effects of resource limitation and environmental regulation (sensu Twilley \& Rivera-Monroy, 2005) are physiological adaptations by the mangrove trees to conserve nutrients, limit herbivory, and maintain internal osmotic balance (Ball, 1988). These adaptations lead to low energetic quality of mangrove organic matter $(\mathrm{OM})$ : Nutrient (nitrogen, $\mathrm{N}$ and phosphorus, $\mathrm{P}$ ) concentrations of senescent leaves are low due to efficient resorption before leaf abscission (Feller et al., 1999); high tannin levels deter herbivory of live leaves (Feller, 1995); high leaf sclerophylly limits water loss from evapotranspiration (Ball, 1988). Given the poor nutritional quality of this recalcitrant material, it is assumed that higher trophic levels do not gain a great amount of energy from the direct consumption of mangrove OM. A prevailing theory of mangrove ecosystem energetics is the detrital pathway described by Odum \& Heald (1975), which postulates that mangrove OM quality is enhanced and made available for secondary trophic level use via microbial decomposition. Coincident with this pathway, microbial OM remineralization promotes nutrient recycling within the forest system for primary producer uptake (Holguin et al., 2001). Thus the rate of mangrove OM degradation is a bottleneck step for system-wide energy flow, with slow rates supporting within-stand nutrient conservation (Reef et al., 2010). Furthermore, any mangrove OM that is not directly consumed, decomposed, or physically exported becomes retained within the soil matrix (Cebrián et al., 1998). Mangrove systems with low decomposition rates and low 
flushing conditions develop deep structural platforms of peat and a biological capacity to maintain elevation relative to sea level rise (McKee et al., 2007). An enhancement of OM decomposition in coastal wetlands by nutrient enrichment may deter this ability to maintain structural peat (Deegan et al., 2012).

Increased nutrient availability within a system may directly or indirectly affect $\mathrm{OM}$ decomposition rates. Indirect effects of nutrient enrichment include changes to the substrate quality or input rate. Nutrient resorption before leaf senescence and abscission can be regulated by the local availability of the same nutrient (Vitousek,1984; Schlesinger et al., 1989; Killingbeck,1996). Feller et al. (1999; 2009) demonstrated a negative relationship between nutrient input and leaf nutrient resorption in fertilized mangrove systems, allowing more of the nutrient to be "lost" to the benthic community under enriched conditions. With regards to substrate quantity, Boto \& Wellington (1983) measured greater leaf production within the first year of fertilization of a north Queensland mangrove, presumably enhancing the amount of organic matter available to the decomposer community. Thus it is reasonable to predict greater rates of $\mathrm{OM}$ decomposition given a more favorable quality and availability of substrate under enriched nutrient conditions. An example of direct effect to OM decomposition by nutrient enrichment would be nutrient limitation relief for the microbial decomposer community by supplementing inorganic nutrients in place of organic substrate-derived nutrients (Debusk \& Reddy, 2005). However, there is evidence of negative control on recalcitrant OM by nutrient enrichment if the inorganic nutrient supply decreases the "need" for OM breakdown by the microbial community (Knorr et al., 2005; Craine et al., 2007). The 
overall effect of nutrient enrichment on OM decomposition continues to present as complex and variable.

Previous studies have demonstrated enhanced heterotrophic microbial activity under direct nutrient stimulus in freshwater systems (Robinson \& Gessner 1999), salt marshes (Wigand et al., 2009; Deegan et al, 2012), and subtropical wetlands (Corstanje et al., 2006; Debusk \& Reddy 2005). Mangrove studies, on the other hand, have presented mixed results of OM decomposition under enriched nutrient conditions. Tam et al. (1998) found no relationship between mangrove litter decay rates along a nutrient gradient extending from a sewage treatment plant at Shenzhen, China. Similarly, Feller et al. (1999) found no difference in decomposition rates of submerged leaves within a fertilized dwarf Rhizophora mangle at Twin Cays, Belize, although below-ground decomposition was enhanced with buried fertilizer cores. Keuskamp et al. (2015) used a multi-factorial design to differentiate source material enrichment versus direct nutrient enrichment of decomposing litter at sites in Belize and Florida. In a P-limited mangrove system, enhancement of litter quality with $\mathrm{P}$ fertilization stimulated $\mathrm{OM}$ decomposition rates; however, direct fertilization of the decomposition matrix without pre-enriched litter did not affect OM decomposition rates. From these works it appears that OM decomposition and retention are modulated via the indirect pathway of substrate quality and not necessarily by direct nutrient input.

This study examines organic carbon mineralization under direct nutrient application as well as sourced organic material from mangrove trees that have encountered nutrient enrichment. The objective of this study is to determine if two years of a surface-level pulse of nutrients would affect mangrove OM degradation. The degradation process was 
examined by three mechanisms: (1) sediment $\mathrm{OM}$ mineralization, (2) leaf litter decomposition, (3) below-ground OM decomposition. I anticipated that the "fast turnover" sediment microbial community would respond to nutrient enrichment more strongly and favorably than "slow turnover" mangrove tree production. I expected a positive response of sediment respiration under direct nutrient enrichment, whereas mangrove leaf decomposition would depend on initial substrate composition.

\section{METHODS}

\section{Site description}

This study was conducted in a fringe mangrove at the eastern edge of the mouth of Jobos Bay $\left(17^{\circ} 55.5^{\prime} \mathrm{N} 60^{\circ} 12.2^{\prime} \mathrm{W}\right)$ in southeastern Puerto Rico (Figure 1-1). Mean annual rainfall ranges $106-114 \mathrm{~cm}$, with a dry season from December through March and a rainy period from July through October (Capella, 2008; Appendix). Air temperature is relatively constant throughout the year, with a range of $16.5-35.7^{\circ} \mathrm{C}$ and an annual average of $26.4^{\circ} \mathrm{C}$ (Appendix). Several small rivers and intermittent streams empty into the bay, but no freshwater discharge reaches the mangrove cays at the mouth of the bay. The tidal profile is mixed diurnal microtidal $(17-36 \mathrm{~cm})$ with largest tides of the year occurring in October (Field 2008).

Site selection was determined by the least relative amount of anthropogenic nutrient input to the local environment, based on the following information: (i) Mangroves at the mouth of Jobos Bay receive overflowing tidal water from a channel that flows directly

from the Caribbean Sea into the bay; (ii) Stable isotope $\left({ }^{15} \mathrm{~N}\right)$ signatures suggest that rooted vegetation communities of Jobos Bay are disconnected from mainland-derived 
nutrient runoff (Bowen \& Valiela, 2008); (iii) Any potential input from the nearest residential community (Punta Pozuelo) would be buffered by a region of sand dunes and forest, and sewage from the community is discharged away from the bay; (iv) The closest Jobos Bay National Estuarine Research Reserve monitoring station (Station 20) has consistently lower ambient nutrient (DIN, DIP) levels compared with stations within the bay.

The experimental site is contained within a Rhizophora mangle (L.) dominated community, which extends from the shoreline 10 to $20 \mathrm{~m}$ and transitions into an Avicennia germinans (L.) forest. Floristic characterization of the site is presented in Chapter 2, and microtopographic measurements are presented in the Appendix.

\section{Nutrient enrichment}

A two-year nutrient enrichment protocol was conducted with three levels of nutrient enrichment: high $\mathrm{N}: \mathrm{P}$ (50N:1P), intermediate $\mathrm{N}: \mathrm{P}$ (16N:1P), and control (ambient channel water). High $\mathrm{N}: \mathrm{P}$ fertilizer represented nutrient input from agriculture sources (sugarcane watershed drainage N:P = 43.9; Faithful et al., 2007), and intermediate N:P fertilizer represented nutrient input from urban sources (urban drainage $\mathrm{N}: \mathrm{P}=12.6$; Hopkinson \& Day, 1980). The annual loading rates were $70 \mathrm{~g} \mathrm{~N} \mathrm{~m}^{-2} \mathrm{y}^{-1}$ and $3.1 \mathrm{~g} \mathrm{P} \mathrm{m}^{-2}$ $\mathrm{y}^{-1}$ (“agriculture” high $\mathrm{N}: \mathrm{P}$ fertilizer), $70 \mathrm{~g} \mathrm{~N} \mathrm{~m}^{-2} \mathrm{y}^{-1}$ and $9.7 \mathrm{~g} \mathrm{P} \mathrm{m}^{-2} \mathrm{y}^{-1}$ (“urban” intermediate $\mathrm{N}: \mathrm{P}$ fertilizer), or $1 \mathrm{~L}$ local channel water without fertilizer (“control”). With the assumption that the experimental area is submerged by $6 \mathrm{~cm}$ of tidal water for half of the year (approximate mean high water; Appendix), the total annual nutrient load is approximately 30 times the amount of DIN loading by tidal overflow (NERRS, 2015; Appendix). An estimate of P loading increase is difficult to make because channel water 
phosphate levels were below the detection limit over $80 \%$ of the experiment time period (NERRS, 2015).

The experiment design employed a randomized block method, where three blocks were spaced at least $100 \mathrm{~m}$ apart along the coastal edge (5 $\mathrm{m}$ from the shoreline). Within each block, three $4 \mathrm{~m}^{2}$ quadrats were established with at least $3.5 \mathrm{~m}$ spacing. Nutrients were added every-other week, coinciding with low tide as often as was feasible. For each quadrat, a stock solution of $\mathrm{NH}_{4} \mathrm{Cl}$ and $\mathrm{KH}_{2} \mathrm{PO}_{4}$ was prepared in $250 \mathrm{~mL}$ deionized water at the laboratory within one week of application, which was then mixed with1 L of local channel water immediately before application with a hand-pumped sprayer. Care was taken to keep the spray nozzle close to the forest floor to minimize volatilization, and to spray evenly throughout the quadrat. Workers stepped outside of the quadrat perimeter or balanced on sturdy prop roots so the forest floor was not disturbed.

\section{Sediment characterization}

At the end of the experiment (October 2013), surface layer (2 to $5 \mathrm{~cm}$ ) sediment cores were sampled to determine bulk density, percent organic content, and total $\mathrm{C}$ and N. For bulk density (g dry weight $/ \mathrm{cm}^{3}$ ), two cores of sediment were sampled using a commercial film canister $\left(30.4 \mathrm{~cm}^{3}\right)$, after fine roots were cut around the circumference to avoid compaction from a strong insertion force. The samples were dried at $45^{\circ} \mathrm{C}$ until a constant weight was reached. The same samples were used to calculate percent organic content by burning at $400^{\circ} \mathrm{C}$ for at least four hours to obtain an ash-free dry weight.

The organic layer of sediment ( 0 to $2 \mathrm{~cm}$ ) was sampled with a cut-off syringe $(2 \mathrm{~cm}$ diameter) at three locations within each quadrat. Mangrove roots with a diameter greater than $2 \mathrm{~mm}$ were sieved out, and the samples were ground with a mortar and pestle. 
Triplicate subsamples of the homogenized sediment were analyzed for total $\mathrm{C}$ and $\mathrm{N}$ on a Flash EA-112 CHNSO analyzer.

\section{Sediment respiration}

Carbon dioxide flux from the sediment surface under unflooded conditions was measured during the dry season (March 2013; 72 weeks from the start of nutrient enrichment) and wet season (October 2013; 104 weeks from the start of nutrient enrichment). All three experimental blocks were measured during daytime of March 2013, but due to the timing and magnitude of tidal flooding only block 1 was available for daytime measurement and block 3 for night-time measurement in October 2013. An additional measurement was made for all blocks during daytime in May, 2014, following 30 weeks of "recovery” from chronic nutrient enrichment pulsing.

For each measurement of $\mathrm{CO}_{2}$ efflux, three to five replicate areas within each quadrat were haphazardly selected to place sediment collars. The selection criteria were areas that did not have significant $\left(>5 \mathrm{~cm}^{2}\right)$ macroalgae cover, L. racemosa pneumatophores or $R$. mangle aerial roots, numerous $(>5)$ or large $(>1 \mathrm{~cm})$ crab burrows, and had not been previously disturbed by coring. If a large below-ground root blocked a complete collar insertion, a new location was selected. To maintain consistency between locations, any large pieces of recent litter fall (e.g., new leaf fall that had not become part of the sediment matrix) were carefully removed by hand and the area was left to rest for at least 30 minutes. PVC sediment collars $(5 \mathrm{~cm}$ wide, $10 \mathrm{~cm}$ diameter) were hand-pushed or gently hammered into the ground to at least $2 \mathrm{~cm}$ depth. Attention was given to minimally disturb sediment at the inner edge of the collar and to keep the collar horizontally aligned during insertion. The exposed collar height was 
measured at four points and the average value was used to calculate the final chamber volume. Pertinent features of the measurement area (crab burrow count and size, macroalgae area) were measured. A soil temperature probe was inserted $2 \mathrm{~cm}$ into the soil approximately $1 \mathrm{~cm}$ from the outer edge of the collar at the time of each measurement.

A Li-Cor 8100 Infra-Red Gas Analyzer (IRGA) chamber was placed over each soil collar, using foam rings to ensure an air-tight seal. Ambient $\mathrm{CO}_{2}$ concentration within the chamber was measured every two seconds for a total incubation of three and a half minutes. The initial 30-seconds of the incubation period was not included in this analysis to allow for gas flushing through the lines.

The values within an incubation period were plotted using the software package LI8100 Viewer and a linear regression was performed to calculate a rate of change in $\mathrm{CO}_{2}$ concentration over the incubation period. Flux values calculated for each incubation were averaged by treatment or by block prior to statistical analysis.

\section{Above-ground Litter Decomposition}

Decomposition of leaf material on the forest floor was measured with litter decomposition bags (Karberg et al., 2008) over a two-month period from July to October (2013). Locally-sourced senescent leaves that had recently fallen on the forest floor (identified as yellow to light-gold color) were collected within each experimental plot and kept cool during transport to the laboratory. It was assumed that leaves collected within each quadrat were sourced by trees that encountered nutrient treatment for that quadrat. The leaves were rinsed in distilled water and air-dried for 24 hours at room temperature. Four to five air-dried leaves were sealed within a $14 \mathrm{~cm} \mathrm{x} 14 \mathrm{~cm}$ fiberglass mesh litter bag with $1 \mathrm{~mm}^{2}$ pores to exclude macroinvertebrate shredders. Care was taken to ensure 
that the leaves lay flat and separated within the litter bags for consistent exposure to the forest surface.

Approximately 50 additional leaves were collected from the surrounding area of all experimental units for a fresh weight to dry weight conversion factor. The leaves were rinsed and air-dried for 24 hours, weighed ("fresh weight”), then dried at $45^{\circ} \mathrm{C}$ until a constant weight was reached (“dry weight”). A linear regression of fresh weight to dry weight was used to convert the fresh weight of the initial litterbag samples to dry weight for comparison with the oven-dry recovered leaf tissue (Appendix)

Immediately after preparation, five bags were deployed at each experimental plot (day 0). One litterbag was removed from each plot at 9, 32, 60, and 90 days and placed in a cooler for transport to the laboratory. At the laboratory, the contents of the bag were submerged in distilled water and cleaned to remove sediment. The litter bag samples were gently cleaned with a soft-bristled paintbrush. After cleaning, the contents of each bag were dried at $45^{\circ} \mathrm{C}$ until a constant weight was reached.

The amount of organic material lost over the decomposition period was expressed as a percentage of the initial mass:

Percent mass remaining $=[($ final dry weight $) /($ calculated initial dry weight $)] * 100$

Most of the decomposing litter displayed a linear decay trend within the study time; therefore, a linear regression was used to compare the mass loss among all of the decomposition time series with the Y-intercept set at 80\% (2012) or 100\% (2013). Based on similar mangrove litter decomposition studies (Tam et al., 1998: 10 weeks; AkeCastillo et al., 2006: 21.5 weeks; Keuskamp et al., 2015: 36 weeks), the degradation trends would likely follow an exponential decay if the incubation period were longer. To 
compare our decay rates $(k)$ with other studies that used an exponential decay model, we used the linear model to calculate the time to reach $50 \%$ decay $\left(t_{0.5}\right)$, which was then fit within the experimental decay model $X=X_{0} e^{-k t}$, where $X$ is the final sample weight, $X_{0}$ is the initial sample weight, $k$ is the decay rate, and $t$ is the time of decomposition in days. Thus $k$ is calculated by

$$
[\ln (0.5)] / t_{0.5}=k
$$

Collected litter samples were ground using a Wiley-grinding mill with a \#20 sieve. Triplicate subsamples were analyzed for C:N ratios using a Flash EA-112 CHNSO analyzer.

\section{Below-ground leaf decomposition}

In July 2012, locally-sourced recently fallen leaves were collected and processed using the same methods as described for above-ground litter bags. Three leaves were sealed in a $5 \mathrm{~cm} \times 10 \mathrm{~cm}$ fiberglass mesh bag with $1 \mathrm{~mm} 2$ pores. For each quadrat, an approximate $20 \mathrm{~cm}$ cut was made into the forest floor at three haphazardly-selected locations. One litter bag was buried within each slice with the long end vertical. The top of the bag was approximately $5 \mathrm{~cm}$ from the surface, with leaf material buried between 5$15 \mathrm{~cm}$. At each quadrat, one litter bag was collected at six months, one year, and 22 months after burial. Extraction of the litter bags often involved cutting mangrove root ingrowth; any mangrove roots inside the bag were separated from the decomposed leaf material as carefully as possible. The extracted litter was cleaned and dried as described for the 2013 above-ground litter bags, and initial to final weights were calculated as described above. 


\section{Data analyses}

A two-way ANOVA with interaction (treatment $\mathrm{x}$ time) and a randomized block effect was used to compare sediment respiration and litter decomposition rates. For decomposition (percent mass remaining) rates and sediment percent organic matter, the data were arcsine transformed. All tests were conducted with SAS version 9.3 with a significance level of 0.05 (“significant”) to 0.08 (“small significance”). If a significant effect was found, a post-hoc Tukey’s HSD pair-wise test for variance was performed to test for significant differences between treatments.

\section{RESULTS}

\section{Sediment properties}

The mangrove forest floor is highly heterogeneous, as demonstrated by the range of bulk density, organic matter content, and percent $\mathrm{C}$ and $\mathrm{N}$ within and between blocks of the mangrove forest (Table 1-1). Due to this variance, there was no significance of sediment C:N between blocks $(\mathrm{p}=0.4)$. There was a small treatment effect on sediment $\mathrm{C}: \mathrm{N}(\mathrm{p}=0.08)$, which was driven by a greater amount of total sediment $\mathrm{C}$ in the fertilized plots. Total C accounted for 25 to $49 \%$ of sediment organic matter content. No significant relationship was found between sediment organic content and sediment $\mathrm{C}: \mathrm{N}$ (data not shown).

Across all quadrats, sediment bulk density and OM content were negatively correlated ( $\mathrm{p}=0.01$; Figure 1-2). Block 1 had the highest bulk density and lowest organic matter content, likely owing to a greater trapping of mineral sediment on the forest floor compared with the more frequently flushed blocks 2 and 3 (Appendix). 
Block 3 had similar organic content as block 1 but a lower bulk density. The greatest difference in organic content was seen in block 2, which had the highest organic content and lowest bulk density in the top sediment layer.

\section{Sediment respiration}

Across all measurement periods (March, October 2013 and May 2014), sediment respiration rates ranged from 0.54 to $2.63 \mu \mathrm{mol} \mathrm{CO}_{2} \mathrm{~m}^{-2} \mathrm{~s}^{-1}$ during daytime measurements and 0.24 to $0.52 \mu \mathrm{mol} \mathrm{CO}_{2} \mathrm{~m}^{-2} \mathrm{~s}^{-1}$ during night time measurements (Figure 1-3). No significant difference of sediment respiration rates between treatments was found for any measurement period $(\mathrm{p}=0.4)$. A significant difference was found between the daytime measurement at block 1 and the night-time measurement at block 3 during October 2013 ( $p<0.001)$. No block effect was found for respiration rates during March 2013. A small block effect was observed during the recovery period, May 2014 (p $=0.07$ ) where sediment respiration rates measured within block 3 were lower compared with the other two blocks.

Linear regressions showed no relationship between sediment respiration rates and the number of crab burrows, surface sediment temperature, or sediment C: $\mathrm{N}$ values (data not shown). Sediment respiration rates after a 30-week recovery period without nutrient enrichment (May, 2013) were not significantly different from respiration rates measured during the nutrient enrichment period (March, 2013) within the same treatment.

\section{Leaf litter decomposition}

Incubation time was a significant factor in leaf litter mass loss $(\mathrm{p}<0.0001$; Figure 1-4). In the first month of incubation, 0 to $30 \%$ of leaf litter mass was lost under control and agriculture treatments, and 15 to $40 \%$ of litter mass was lost under urban treatment 
(Figure 1-5). The percent of litter mass remaining ranged from 19 to $45 \%$ by 90 days (Figure 1-5). Nutrient treatments had no significant effect on litter decomposition values across any time point $(p=0.5)$. The time to $50 \%$ mass decay $\left(t_{50}\right)$ ranged from 61 to 110 days, with an average of 79 days (Table 1-2). The decay constant (k) was $0.009 \mathrm{~d}^{-}$

${ }^{1}$ (range 0.006 to $0.011 \mathrm{~d}^{-1}$ ). As decomposition constant $(\mathrm{k})$ values are calculated from mass loss trends, there was also no significant effect of nutrient treatment on $\mathrm{k}$ values ( $\mathrm{p}$ $=0.7)$.

Incubation time was a significant factor for litter $\mathrm{C}: \mathrm{N}$ values $(\mathrm{p}<0.0001$; Figure 1 6). Nutrient treatment had a small effect on the relationship between litter decay and C:N content ( $(\mathrm{p}=0.07)$, with lower $\mathrm{C}: \mathrm{N}$ values for urban-enriched litter.

More than $80 \%$ of initial leaf material had decomposed within the first six months of below-ground incubation (Figure 1-7). There was little decomposition of the buried leaf material between six months and one year. At the final below-ground litter bag collection (22 months after burial), the remaining leaf material had disintegrated into small pieces $\left(<0.25 \mathrm{~cm}^{2}\right)$ and was completely integrated with the fine root matrix. Thus I determined all leaf material to be completely decomposed after 22 months of shallow burial for all quadrats. There was no significant effect of nutrient treatment on belowground decomposition for any of the incubation periods.

\section{DISCUSSION}

The purpose of this experiment was to determine if organic carbon mineralization rates on a mangrove forest floor would be modified under anthropogenic nutrient 
enrichment. Within a single mangrove stand, there was considerable variation in terms of edaphic structure (sediment bulk density, organic matter (OM) content) and environmental conditions (tidal inundation duration and frequency) along the coastal fringe. Yet considering the differences between experimental blocks, treatments, and time periods, rates of sediment respiration and $\mathrm{OM}$ decomposition were remarkably consistent.

\section{Sediment Respiration}

Given little temporal or treatment-driven difference between sediment respiration values, the grand average of daytime respiration across all units and measurement periods was $1.42 \pm 0.06 \mu \mathrm{mol} \mathrm{CO} 2 \mathrm{~m}^{-2} \mathrm{~s}^{-1}$, with a range of 0.54 to $2.63 \mu \mathrm{mol} \mathrm{CO} 2 \mathrm{~m}^{-2} \mathrm{~s}^{-1}$ (Figure 1-3). The high value of this range exceeds that reported by Kristensen et al. (2008) from extracted sediment cores of Tanzanian mangroves (maximum value of $0.69 \mu \mathrm{mol} \mathrm{CO} 2 \mathrm{~m}^{-}$ $\left.2 \mathrm{~s}^{-1}\right)$. A review of $\mathrm{CO}_{2}$ efflux measurements from exposed mangrove sediments also does not reach the high values found in this system $\left(0.80 \pm 0.09 \mu \mathrm{mol} C O 2 \mathrm{~m}^{-2} \mathrm{~s}^{-1}\right.$; Alongi, 2009). However, a survey of globally-distributed dwarf and fringe mangroves by Lovelock et al. (2008) found a range of mean sediment respiration from approximately 0.25 to $2.97 \mu \mathrm{mol} \mathrm{CO} 2 \mathrm{~m}^{-2} \mathrm{~s}^{-1}$, which contains the range of values presented here.

The greatest difference in sediment respiration values was observed in October 2013, when block $3 \mathrm{CO}_{2}$ flux was measured at night (Figure 1-3). This result contrasts with work by Kristensen et al. (2008), who found that $\mathrm{CO}_{2}$ flux measurements under light and dark conditions of extracted mangrove sediment cores were not strongly different. In this study, the strong difference of respiration values between blocks 1 and 3 was not observed during the other two measurement periods, which suggests a factor 
associated with day and night drives the difference. Microbial respiration activity is often temperature-dependent (Qiu et al., 2005), but sediment temperatures at this period were just under one degree apart from day to night $\left(27.4^{\circ} \mathrm{C}\right.$ vs. $26.5^{\circ} \mathrm{C}$, respectively). The average air temperature during this measurement period shifted from a daytime high of $30^{\circ} \mathrm{C}$ to a nighttime low of $25^{\circ} \mathrm{C}$ (NERRS 2015), which may have played a role in the lower nighttime value of benthic respiration. It would be useful to examine the contribution of mangrove roots to surface $\mathrm{CO}_{2}$ flux rates (Lovelock et al. 2006; Kuzyakov 2002), and whether a day/night difference in mangrove below-ground respiration contributes to this difference.

Regarding the lack of microbial response to nutrient enrichment, an appropriate concern is whether the benthic microbial heterotrophs encountered the additional $\mathrm{N}$ at a dose level or time interval that would lead to a measurable response. Work by Corredor \& Morrell (1994) and Whigham et al. (2009) show rapid enhanced denitrification rates in mangrove sediments in response to nitrate enrichment. Corredor \& Morrell (1994) measured denitrification rates in a mangrove forest along a nutrient gradient extending from a sewage treatment plant. Sediment denitrification rates decreased at greater distance from the sewage source, although potential denitrification rates (with available substrate) were maintained. Whigham et al. (2009) found higher rates of denitrification for several days after monthly doses of aqueous nitrate in a Florida stunted Avicennia germinans forest. Based on the rapid positive response by the denitrifier community under both scenarios, it may be possible the added nutrients were effectively removed, thereby preventing a long-term pool of available N. However, stable isotope analysis of ${ }^{15} \mathrm{~N}$ tracer (see Chapter 3) and enhanced efflux of DIN from the sediment to overlying 
tidal water (Appendix) demonstrate that added $\mathrm{N}$ was retained within the surface sediment and overlying organic layer for an extended time period (weeks to months).

The lack of a microbial response to nutrient enrichment is confirmed by previous work in mangrove systems. Lovelock (2008) notes that anthropogenic land use was not the primary driver of sediment respiration rates in a global survey of dwarf and fringe mangrove sites. Kristensen et al. (2011) likewise found no effect of nutrient enrichment on $\mathrm{OM}$ mineralization (except see below). One possible explanation of a lack of response to nutrient enrichment is the "nitrogen mining theory" (Craine et al., 2007), which postulates that $\mathrm{N}$-limited microbial communities break down recalcitrant $\mathrm{OM}$ to acquire nitrogenous compounds; when the $\mathrm{N}$ limitation is lifted, the microbes have less energetic incentive to continue the decomposition process. Thus $\mathrm{N}$ fertilization may actually inhibit microbial decay of highly refractory organic substrate, which constitutes the bulk of mangrove peat (Middleton \& McKee, 2001). In support of this concept for mangrove systems, Keuskamp et al. (2012) found that N enrichment alone had no effect on the rate of sediment $\mathrm{OM}$ mineralization in mangrove sites, but microbial activity spiked upon the co-introduction of labile C (glucose) and N enrichment. They concluded that sediment OM mineralization was energy limited due to the refractory OM matrix, which could be further inhibited by high tannin content (Robertson, 1988). Kristensen et al. (2011) found no effect of nutrient enrichment from a sewage site on mangrove microbial processes, but a greater input of labile organic C from an algae bloom "of anthropogenic origin” enhanced $\mathrm{CO}_{2}$ efflux in the intertidal zone. Thus, nutrient enrichment may affect sediment mineralization rates via a cascade effect, where nutrient 
enrichment enhances algae production, which delivers labile organic carbon to the mangrove sediments, which stimulates heterotrophic decomposition.

Based on these works, a broader examination of the nutrient mining theory for benthic mangrove response to nutrient enrichment is needed, especially with the consideration that labile organic substrate may be linked with nutrient enrichment via primary-treatment sewage and septic systems, agriculture practices that utilize urea or animal wastes, or enhanced organic material production in eutrophic coastal waters.

\section{Leaf Litter Decomposition}

While sediment $\mathrm{CO}_{2}$ flux measures heterotrophic microbial activity within the top layer of the mangrove peat platform, leaf litter decomposition values indicate microbial use of recently-fallen organic material that is in a constant state of flux into and out of the mangrove system. The rate of litter decomposition depends on the quality and availability of the substrate as well as several other factors including macroinvertebrate (shredder) activity, physical shearing forces (e.g., tidal submersion), temperature, oxidation state of the local environment, and resource limitations of the decomposer community such as nutrient availability (Benner \& Hodson, 1985; Mackey \& Smail, 1996; Twilley et al., 1997). Thus a comparison of litter decomposition rates between systems is somewhat difficult without all biological and environmental factors taken into consideration. However, the values presented in Table 1-3 demonstrate that litter decomposition rates from this study fit within previously reported decomposition values from other fringe mangrove systems, whether natural (Twilley et al., 1986; 1997; AkéCastillo et al., 2006) or provided with additional nutrients (Tam et al. 1998). These studies suggest that nutrient enrichment does not necessarily play a dominant role in 
mangrove litter decomposition, and the factors described above are important covariates to be considered for an accurate prediction of decomposition rates. For example, Keuskamp et al. (2015) reported that physical setting (Florida vs. Belieze) was a better predictor of litter decomposition rates than nutritional status, presumably due to other environmental factors.

The process of OM decomposition can be described in two phases: (1) an initial leaching stage, where soluble compounds and labile material are easily dissolved within the aqueous medium; (2) a colonization and slow decomposition stage, where refractory compounds such as lignins are chemically broken down (Chale, 1993; Davis et al., 2003). The curves of litter mass loss were generally linear throughout this study, suggesting that the decomposition stage had not fully matured to the slow process of refractory material decomposition. The time to reach 50\% decay ranged from 61 to 110 days, which is comparable to litter decomposition in a similar fringe mangrove studied by Aké-Castillo et al. (2006; Table 1-3). This $t_{50}$ range was faster than that reported by Twilley et al. (1986) in basin mangroves, which are less regularly flushed than fringe mangroves (Lugo and Snedaker 1974). The range of $t_{50}$ was much higher in Tam et al. (1998) compared with this study, but those decomposition rates under wastewater application were not significantly different than control sites (Tam et al. 1998). Tam et al. (1998) report rainfall levels an order of magnitude greater than received at Jobos Bay, which suggests that the freshwater input has a positive influence on above-ground litter decomposition.

Mangrove leaf litter became fully decomposed and integrated within the mangrove root complex within two years of burial. Middleton \& McKee (2001) reported 27 +/- 5\% mass remaining of buried leaves after 230 days of incubation, which was similar to the 
values at one year of incubation in this study. As I used fiberglass mesh litterbags, this rate precluded the effect of macroinvertebrate shredding, which would have enhanced the decomposition rate. The relatively fast break-down of buried mangrove leaves is an indication that mangrove leaf litter is not a primary component of mangrove peat material (Middleton \& McKee, 2001).

Under both ambient and fertilized treatments, mangrove litter C:N decreased as decomposition progressed (Figure 1-6). The main driver of this nutritional change is $\mathrm{N}$ immobilization by microbial colonization of the OM substrate. Microbial colonization and break-down of organic substrate is linked to exo-enzyme secretion (Keuskamp et al., 2015b) and nitrogen fixation (Holguin et al., 2001), which enrich the OM-microbial complex with nitrogenous compounds. Additionally, plant tannins may bind available N (Kraus et al., 2003), further immobilizing the $\mathrm{N}$ in the $\mathrm{OM}$ matrix. The similar C:N values of control and fertilized decomposing litter suggests that either the microbial community was not strongly limited by $\mathrm{N}$ or that the tannin content in fertilized leaves was reduced by $\mathrm{N}$ enrichment (Kraus et al., 2003), which allowed more of the available $\mathrm{N}$ to be leached from the leaf litter matrix.

\section{CONCLUSION}

Organic carbon cycling within the mangrove system is driven by highly refractory material. The slow process of $\mathrm{C}$ mineralization and strong $\mathrm{N}$ immobilization are critical factors for ecosystem function, including peat formation and carbon sequestration to nutrient conservation within the mangrove stand. Given the nutrient enrichment amount and duration of this experiment, it appears that the benthic decomposer community is not 
strongly limited by available $\mathrm{N}$ and/or $\mathrm{P}$. I recommend a future evaluation of mangrove litter decomposition with an emphasis on physical and environmental setting as well as nutrient availability. I also recommend more work to pursue the role of labile organic C in conjunction with nutrient enrichment for benthic respiration activity in a variety of mangrove environmental settings. 


\section{REFERENCES}

Aké-Castillo, J. A., G. Vázquez, \& J. López-Portillo, 2006. Litterfall and decomposition of Rhizophora mangle L. in a coastal lagoon in the southern Gulf of Mexico. Hydrobiologia 559:101-111.

Alongi, D. M., 2009. The Energetics of Mangrove Forests. Springer, New York.

Ball, M.C., 1988. Ecophysiology of mangroves. Trees 2: 129-142.

Benner, R. \& R. E. Hodson, 1985. Microbial degradation of the leachable and lignocellulosic components of leaves and wood from Rhizophora mangle in a tropical mangrove swamp. Marine Ecology Progress Series 23: 221-230.

Boto, K. G. \& J. T. Wellington, 1983. Phosphorus and nitrogen nutritional status of a northern Australian mangrove forest. Marine Ecology Progress Series 11: 63-69.

Bouillon, S., R. M. Connolly, \& S. Y. Lee, 2008. Organic matter exchange and cycling in mangrove ecosystems: Recent insights from stable isotope studies. Journal of Sea Research 59: 44-58.

Bowen, J. L. \& I. Valiela, 2008. Using $\delta^{15} \mathrm{~N}$ to assess coupling between watersheds and estuaries in temperate and tropical regions. Journal of Coastal Research 24: 804813.

Capella, J., 2008. Environmental setting. In Field, R. (ed.) Jobos Bay Estuarine Profile. Revised June 2008 by Angel Dieppa. Jobos Bay National Estuarine Research Reserve. https://coast.noaa.gov/data/docs/nerrs/Reserves_JOB_SiteProfile.pdf. Last accessed December, 2015.

Cebrián J., M. Williams, J. McClelland, \& I. Valiela, 1998. Ecology Letters 1: 165-170. 
Chale, F. M. M., 1993. Degradation of mangrove leaf litter under aerobic conditions. Hydrobiologia 257: 177-183.

Corredor, J. E. \& J. M. Morell, 1994. Nitrate depuration of secondary sewage effluents in mangrove sediments. Estuaries 17: 295-300.

Corredor, J. E., R. W. Howarth, R. R. Twilley, \& J. M. Morell, 1999. Nitrogen cycling and anthropogenic impact in the tropical interamerican seas. Biogeochemistry 46: 163-178.

Corstanje, R., Reddy, K.R., Portier, K.M., 2006. Typha latifolia and Cladium jamaicense litter decay in response to exogenous nutrient enrichment. Aquatic Botany, 84: 70-78.

Craine, J. M., C. Morrow, \& N. Fierer, 2007. Microbial nitrogen limitation increases decomposition. Ecology 88: 2105-2113.

Davis, S. E., C. Corronado-Molina, D. L. Childers, \& J. W. Day, 2003. Temporally dependent $\mathrm{C}, \mathrm{N}$, and $\mathrm{P}$ dynamics associated with the decay of Rhizophora mangle L. leaf litter in oligotrophic mangrove wetlands of the Southern Everglades. Aquatic Botany 75 199-215.

Das, S. \& J. R. Vincent, 2009. Mangroves protected villages and reduced death toll during Indian super cyclone. Proceedings of the National Academy of Sciences of the United States of America. 106: 7357-7360.

Debusk, W. F. \& K. R. Reddy, 2005. Litter decomposition and nutrient dynamics in a phosphorus enriched everglades marsh. Biogeochemistry 75: 217-240. 
Deegan, L. A., D. S. Johnson, R. S. Warren, B. J. Peterson, J. W. Fleeger, S. Fagherazzi, \& W. M. Wollheim, 2012. Coastal eutrophication as a driver of salt marsh loss. Nature 490: 388-392.

Donato, D. C., J. B. Kauffman, D. Murdiyarso, S. Kurnianto, M. Stidham, \& M. Kanninen, 2011. Mangroves among the most carbon-rich forests in the tropics. Nature Geoscience 4: 293-297.

Downing, J. A., M. McClain, R. Twilley, J. M. Melack, J. Elser, N. N. Rabalais, W.M. Lewis, R. E. Turner, J. Corredor, D. Soto, A. Yanez-Arancibia, J. A. Kopaska, \& R. W. Howarth,1999. The impact of accelerating land-use change on the N-cycle of tropical aquatic ecosystems: Current conditions and projected changes. Biogeochemistry 46: 109-148.

Ewel, J. J. \& J. L. Whitmore, 1973. The Ecological Life Zones of Puerto Rico and the U. S. Virgin Islands. Forest Service Research Paper ITF-18.

Faithful, J. W., J. Brodie, A. Hooper, P. Leahy, G. Henry, W. Finlayson \& D. Green, 2007. Plot-scale runoff of nutrients and sediment under varying management regimes on a banana and cane farm in the wet tropics, Queensland. Australian Centre for Tropical Freshwater Research, Report No. 07/10.

Field, R. M., Introduction and Summary. In In Field, R. (ed.) Jobos Bay Estuarine Profile. Revised June 2008 by Angel Dieppa. Jobos Bay National Estuarine Research Reserve. https://coast.noaa.gov/data/docs/nerrs/Reserves_JOB_SiteProfile.pdf. Last accessed December, 2015.

Feller, I. C., 1995. Effects of nutrient enrichment on growth and herbivory of dwarf red mangrove (Rhizophora mangle). Ecological Monographs 65: 477-505. 
Feller, I. C., D. F. Whigham, J. P. O’Neill, \& K. L. McKee,1999. Effects of Nutrient Enrichment on within-Stand Cycling in a Mangrove Forest. Ecology 80: 21932205.

Feller I. C., C. E. Lovelock, C. Piou, 2009. Growth and Nutrient Conservation in Rhizophora mangle in response to fertilization along latitudinal and tidal gradients. Smithsonian Contribution to the Marine Sciences. 38: 345-358.

Hopkinson, C. S. \& J. W. Day, 1980. Modeling the relationship between development and storm water and nutrient runoff. Environmental Management 4: 315-324.

Holguin, G., P. Vazquez, Y. Bashan, 2001. The role of sediment microorganisms in the productivity, conservation, and rehabilitation of mangrove ecosystems: an overview. Biology and Fertility of Soils 33: 265-278.

Howarth, R. W. 2008. Coastal nitrogen pollution: A review of sources and trends globally and regionally. Harmful Algae 8: 14-20.

Howarth, R. W. \& R. Marino, 2006. Nitrogen as the limiting nutrient for eutrophication in coastal marine ecosystems: Evolving views over three decades. Limnology and Oceanography 51: 364-376.

Karberg, N. J., N. A. Scott, \& C. P. Giardina, 2008. Methods for estimating litter decomposition. In Hoover, C. M. (ed.) Field Measurements for Forest Carbon Monitoring, Springer, New York: 103-111.

Keuskamp, J. A., H. Schmitt, H. J. Laanbroek, J. T. A. Verhoeven, \& M. M. Hefting, 2012. Nutrient amendment does not increase mineralisation of sequestered carbon during incubation of a nitrogen limited mangrove soil. Soil Biology \& Biochemistry 57: 822-829. 
Keuskamp, J. A., M. M. Hefting, B. J. J. Dingemans, J. T. A. Verhoeven, \& I. C. Feller, 2015(a). Effects of nutrient enrichment on mangrove leaf litter decomposition. Science of the Total Environment 508: 402-410.

Keuskamp, J. A., I. C. Feller, H. J. Laanbroek, J. T. A. Verhoeven, \& M. M. Hefting, 2015(b). Short- and long-term effects of nutrient enrichment on microbial exoenzyme activity in mangrove peat. Soil Biology \& Biochemistry 81: 38-47.

Killingbeck, K. T., 1996. Nutrients in senesced leaves: Keys to the search for potential resorption and resorption proficiency. Ecology 77: 1716-1727.

Knorr, M., S. D. Frey, \& P. S. Curtis, 2005. Nitrogen additions and litter decomposition: A meta-analysis. Ecology 86: 3252-3257.

Kraus et al., 2003. Tannins in nutrient dynamics of forest ecosystems - a review. Plant and Soil 256: 41-66.

Kristensen, E., S. Bouillon, T. Dittmar, \& C. Marchand, 2008. Organic carbon dynamics in mangrove ecosystems: A review. Aquatic Botany 89: 201-219.

Kristensen, E., Flindt, M.R., Ulomi, S., Borges, A.V., Abril, G., Bouillon, S., 2008. Emission of $\mathrm{CO}_{2}$ and $\mathrm{CH}_{4}$ to the atmosphere by sediments and open waters in two Tanzanian mangrove forests. Marine Ecology Progress Series, 370: 53-67.

Kristensen, E., Mangion, P., Tang, M., Flindt, M.R., Holmer, M. and Ulomi, S., 2011. Microbial carbon oxidation rates and pathways in sediments of two Tanzanian mangrove forests. Biogeochemistry, 103: 143-158.

Kuzyakov, Y., 2002. Separating microbial respiration of exudates from root respiration in non-sterile soils: a comparison of four methods. Soil Biology and Biochemistry, 34(11), pp.1621-1631. 
Lovelock, C.E., Ruess, R.W., Feller, I.C., 2006. Fine root respiration in the mangrove Rhizophora mangle over variation in forest stature and nutrient availability. Tree physiology, 26: 1601-1606.

Lovelock, C.E., 2008. Soil respiration and belowground carbon allocation in mangrove forests. Ecosystems, 11: 342-354.

Mackey, A. P., and G. Smail, 1996. The decomposition of mangrove litter in a subtropical mangrove forest. Hydrobiologia 332: 93-98.

McKee, K. L., D. R. Cahoon, \& I. C. Feller, 2007. Caribbean mangroves adjust to rising sea level through biotic controls on change in soil elevation. Global Ecology and Biogeography 1-12.

Middleton, B. A. \& K.L. McKee, 2001. Degradation of mangrove tissues and implications for peat formation in Belizean island forests. Journal of Ecology. 89: 818-828.

Mumby, P. J., A. J. Edwards, J. E. Arias-Gonzalez, K. C. Lindeman, P. G. Blackwell, A. Gall, M. I. Gorczynska, A. R. Harborne, C. L. Pescod, H. Renken, C. C. C. Wabnitz, G. Llewellyn, 2004. Mangroves enhance the biomass of coral reef fish communities in the Caribbean. Nature 427: 533-536.

Nixon, S. W., B. A. Buckley, S. L. Granger, M. Entsua-Mensah, O. Ansa-Asare, M. J. White, R. A. McKinney \& E. Mensah, 2007. Anthropogenic enrichment and nutrients in some tropical lagoons of Ghana, West Africa. Ecological Applications 17: S144-S164.

NERRS, 2015. NOAA National Estuarine Research Reserve System (NERRS). Systemwide Monitoring Program. Data accessed from the NOAA NERRS Centralized 
Data Management Office website: http://www.nerrsdata.org/;. Last accessed September, 2015.

NOAA-NERR, 2015. http://nerrs.noaa.gov/reserves/jobos-bay.html Last accessed March, 2016.

Odum, W. E. \& E. J. Heald, 1975. Mangrove forests and aquatic productivity. In Hasler, A. D. (ed.) Coupling of Land and Water Systems. Springer, New York: 129-136.

Qiu, S., A. J. McComb, R. W. Bell, J. A. Davis, 2005. Response of soil microbial activity to temperature, moisture, and litter leaching on a wetland transect during seasonal refilling. Wetlands Ecology and Management 13: 43-54.

Reef, R., I. C. Feller, \& C. E. Lovelock, 2010. Nutrition of mangroves. Tree Physiology 30: 1148-1160.

Robertson, A. I.,1988. Decomposition of mangrove leaf litter in tropical Australia. Journal of Experimental Marine Biology and Ecology 116: 235-247.

Robinson, C.T. \& Gessner, M.O., 2000. Nutrient addition accelerates leaf breakdown in an alpine springbrook. Oecologia, 122: 258-263.

Schlesinger, W. H., E. H. DeLucia, W. D. Billings, 1989. Nutrient-use efficiency of woody plants on contrasting soils in the Western Great Basin, Nevada. Ecology 70: 105-113.

Tam N. F. Y., Y. S. Wong, C. Y. Lan, \& L. N. Wang, 1998. Litter production and decomposition in a subtropical mangrove swamp receiving wastewater. Journal of Experimental Marine Biology and Ecology 226: 1-18. 
Twilley, R. R. \& Rivera-Monroy, V. H., 2005. Developing performance measures of mangrove wetlands using simulation models of hydrology, nutrient biogeochemistry, and community dynamics. Journal of Coastal Research 40: 79_ 93.

Twilley, R. R., A. E. Lugo, \& C. Patterson-Zucca, 1986. Litter production and turnover in basin mangrove forests in Southwest Florida. Ecology 67: 670-683.

Twilley, R. R., M. Pozo, V. H. Garcia, V. H. Rivera-Monroy, R. Zambrano \& A. Bodero,1997. Litter Dynamics in Riverine Mangrove Forests in the Guayas River Estuary, Ecuador. Oecologia 111: 109-122.

Vitousek, P. M.,1984. Litterfall, nutrient cycling, and nutrient limitation in tropical forests. Ecology, 65: 285-298.

Whigham, D. F., J. T. A. Verhoeven, V. Samarkin \& P. J. Megonigal, 2009. Responses of Avicennia germinans (black mangrove) and the soil microbial community to nitrogen addition in a Hypersaline Wetland. Estuaries and Coasts 32:926-936.

Wigand, C., P. Brennan, M. Stolt, M. Holt, \& S. Ryba, 2009. Soil respiration rates in coastal marshes subject to increasing watershed nitrogen loads in southern New England, USA. Wetlands 29: 952-963.

Zitello, A. G., D. R. Whitall, A. Dieppa, J. D. Christensen, M. E. Monaco, \& S. O. Rohmann, 2008. Characterizing Jobos Bay, Puerto Rico: A watershed modeling analysis and monitoring plan. NOAA Technical Memorandum NOS NCCOS 76. $81 \mathrm{pp}$. 


\section{TABLES AND FIGURES}

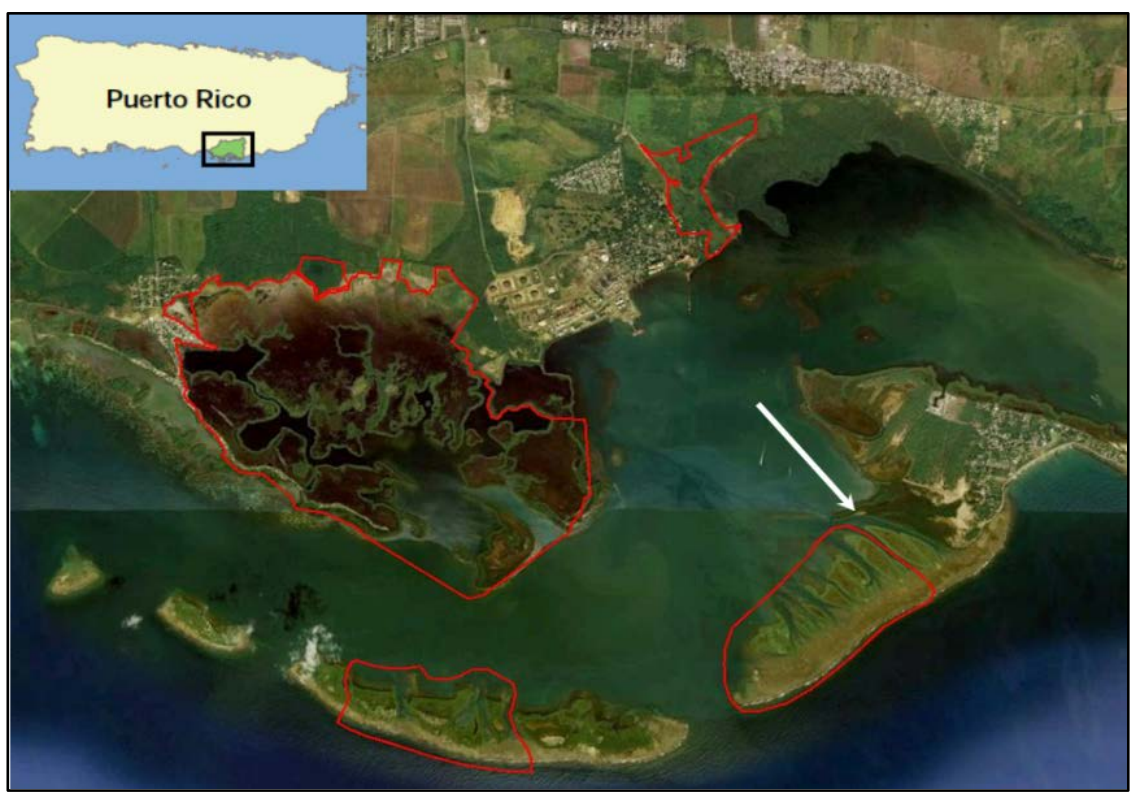

Figure 1-1. Satellite image of Jobos Bay, located in southeastern Puerto Rico. The boundaries of the Jobos Bay National Estuarine Research Reserve are outlined in red. A white arrow indicates the location of the nutrient enrichment experiment at offshore keys, approximately $3 \mathrm{~km}$ from the mainland (image credits: Zitello et al. 2008; NOAA-NERR 2015). 
Table 1-1. Edaphic characterization of experimental quadrats grouped within three blocks of a fringe mangrove forest. For each block, three quadrats were randomly assigned a nutrient regime of high (50:1) N:P fertilizer (“Agriculture”), intermediate (16:1) N:P fertilizer (“Urban”), or locally-sourced channel water (“Control”). Samples were collected after two years of nutrient enrichment (October, 2013). Values are mean +/- 1 S.E. "ND" indicates that the data are not available. There was no effect of nutrient treatment on bulk density or percent organic matter. There was a small treatment effect on molar $\mathrm{C}: \mathrm{N}(\mathrm{p}=0.08)$.

\begin{tabular}{|c|c|c|c|c|c|c|c|c|c|}
\hline \multirow[b]{3}{*}{$\begin{array}{l}\text { Bulk density (g/cm3) } \\
(\mathrm{n}=3)\end{array}$} & \multicolumn{3}{|c|}{ Block 1} & \multicolumn{3}{|c|}{ Block 2} & \multicolumn{3}{|c|}{ Block 3} \\
\hline & Control & Urban & Agriculture & Control & Urban & Agriculture & Control & Urban & Agriculture \\
\hline & $0.53(0.05)$ & $0.48(0.07)$ & $0.38(0.03)$ & $0.17(0.03)$ & $0.18(0.02)$ & $0.23(0.02)$ & $0.23(0.02)$ & 0.35 & $0.28(0.03)$ \\
\hline $\begin{array}{l}\text { Organic matter (\%) } \\
(\mathrm{n}=2)\end{array}$ & $12.9(1.4)$ & $15.4(2.5)$ & $26.8(14.4)$ & $47.6(14.9)$ & $45.4(5.1)$ & $36.3(0.6)$ & $18.2(4.7)$ & $22.4(7.2)$ & $24.0(2.1)$ \\
\hline $\begin{array}{l}\text { Total C (\% by weight) } \\
(\mathbf{n}=3)\end{array}$ & $3.34(0.60)$ & $5.46(0.79)$ & ND & $19.46(0.88)$ & 20.66 (1.85) & ND & $8.97(1.58)$ & $10.90(0.42)$ & ND \\
\hline $\begin{array}{l}\text { Total N (\% by weight) } \\
(\mathrm{n}=3)\end{array}$ & $0.13(0.03)$ & $0.19(0.03)$ & ND & $0.74(0.03)$ & $0.77(0.08)$ & ND & $0.34(0.05)$ & $0.34(0.02)$ & ND \\
\hline $\begin{array}{l}\text { Molar C:N } \\
(\mathrm{n}=3)\end{array}$ & $32.0(1.8)$ & $33.4(1.0)$ & ND & $30.6(0.4)$ & $31.4(1.2)$ & ND & 30.9 (1.7) & $37.6(3.5)$ & ND \\
\hline
\end{tabular}




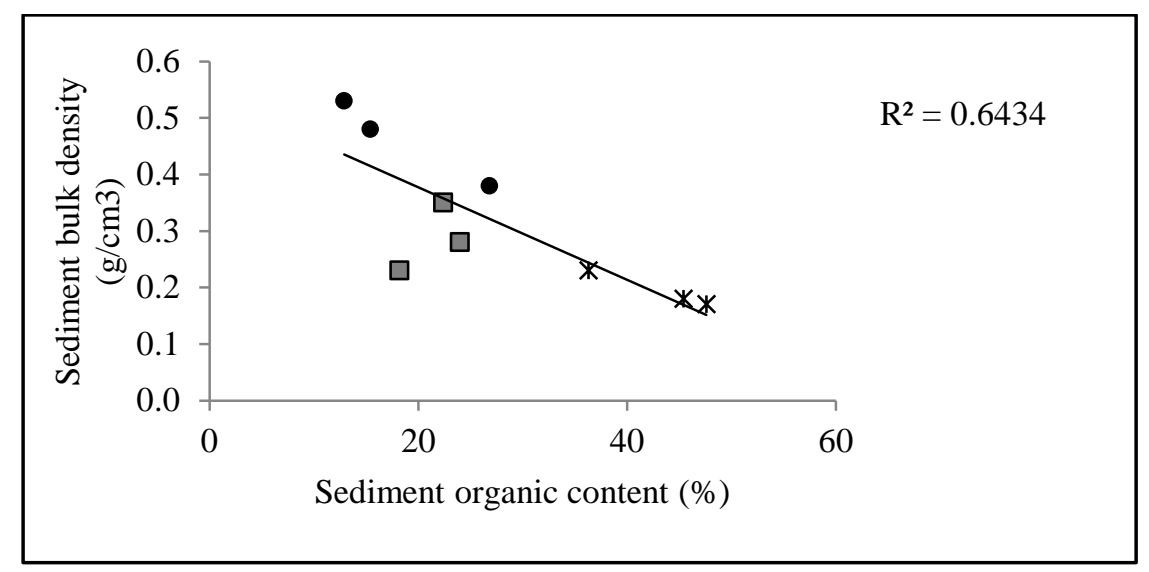

Figure 1-2. Sediment bulk density (dry mass by volume) and percent organic content (ash-free dry weight content) of the surface organic layer of the mangrove forest sediment $(0$ to $5 \mathrm{~cm}$ ) Data were averaged from collections in July 2011 and October 2013. Circles represent block 1, crossed lines represent block 2, squares represent block 3. Linear regression line for all nine quadrats. 


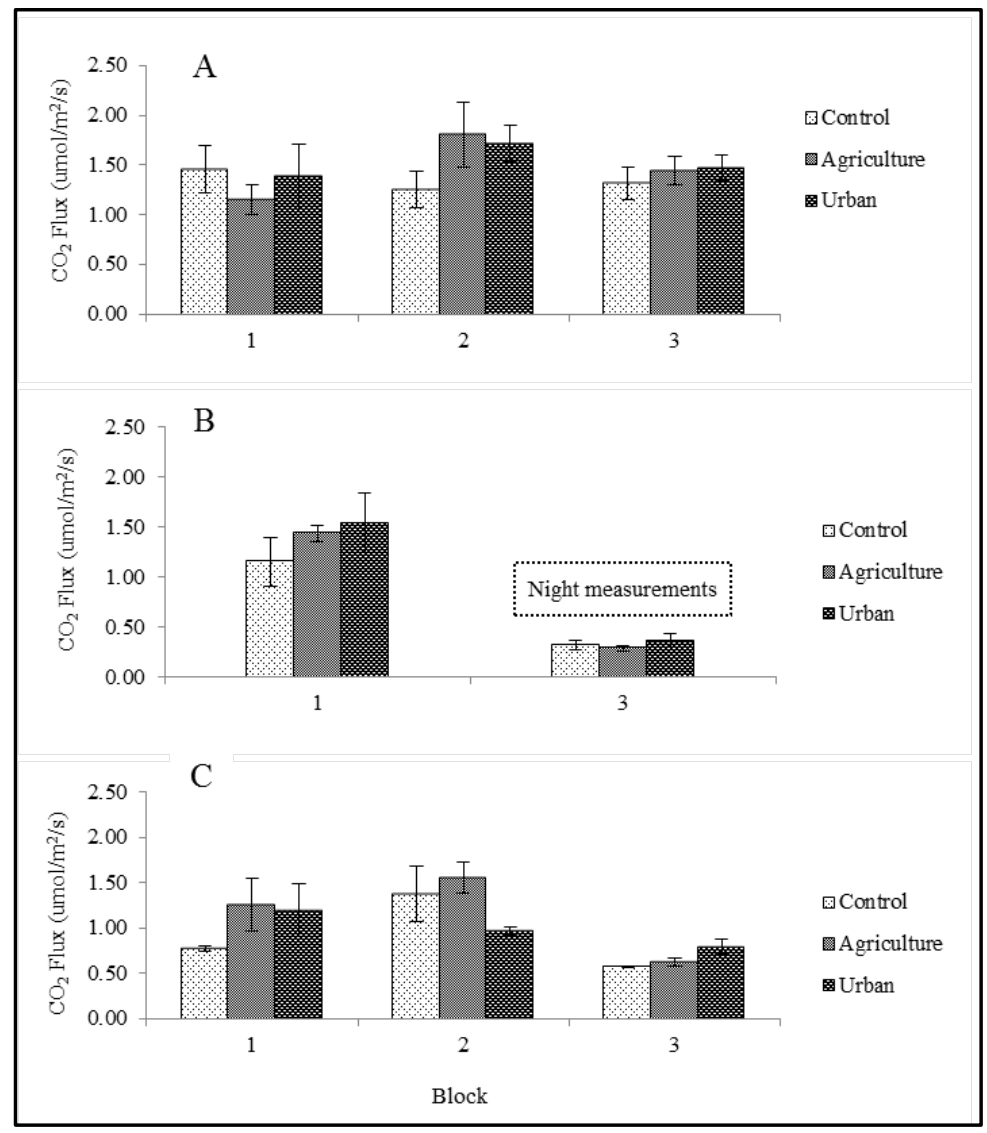

Figure 1-3. Sediment respiration measured by $\mathrm{CO}_{2}$ flux from the unflooded forest floor at three time periods: (A) March 2013, 72 weeks of nutrient enrichment; (B) October 2013, 104 weeks of nutrient enrichment; (C) May 2014, 30 weeks after nutrient enrichment ended. Values are means +/- 1 S.E. Blocks 2 and 3 was constantly flooded during the day for October 2013, so gas exchange could not be measured. 


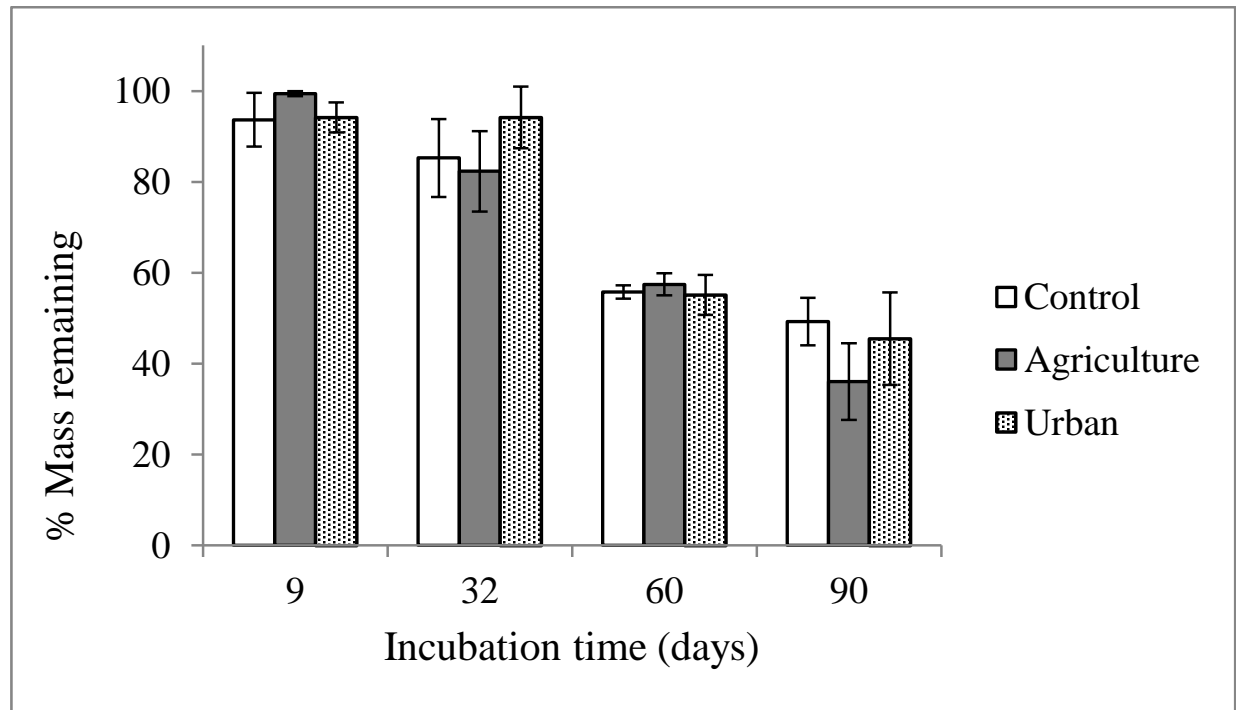

Figure 1-4. Percent mass remaining for below-ground mangrove leaf litter decomposition. The litter was buried at 5 to $15 \mathrm{~cm}$ depth in July 2012. Values are means across blocks $(n=3)$. Error bars indicate $+/-1$ S.E. Litter material recovered at 22 months past the burial date was integrated with fine root material and was considered fully degraded. 


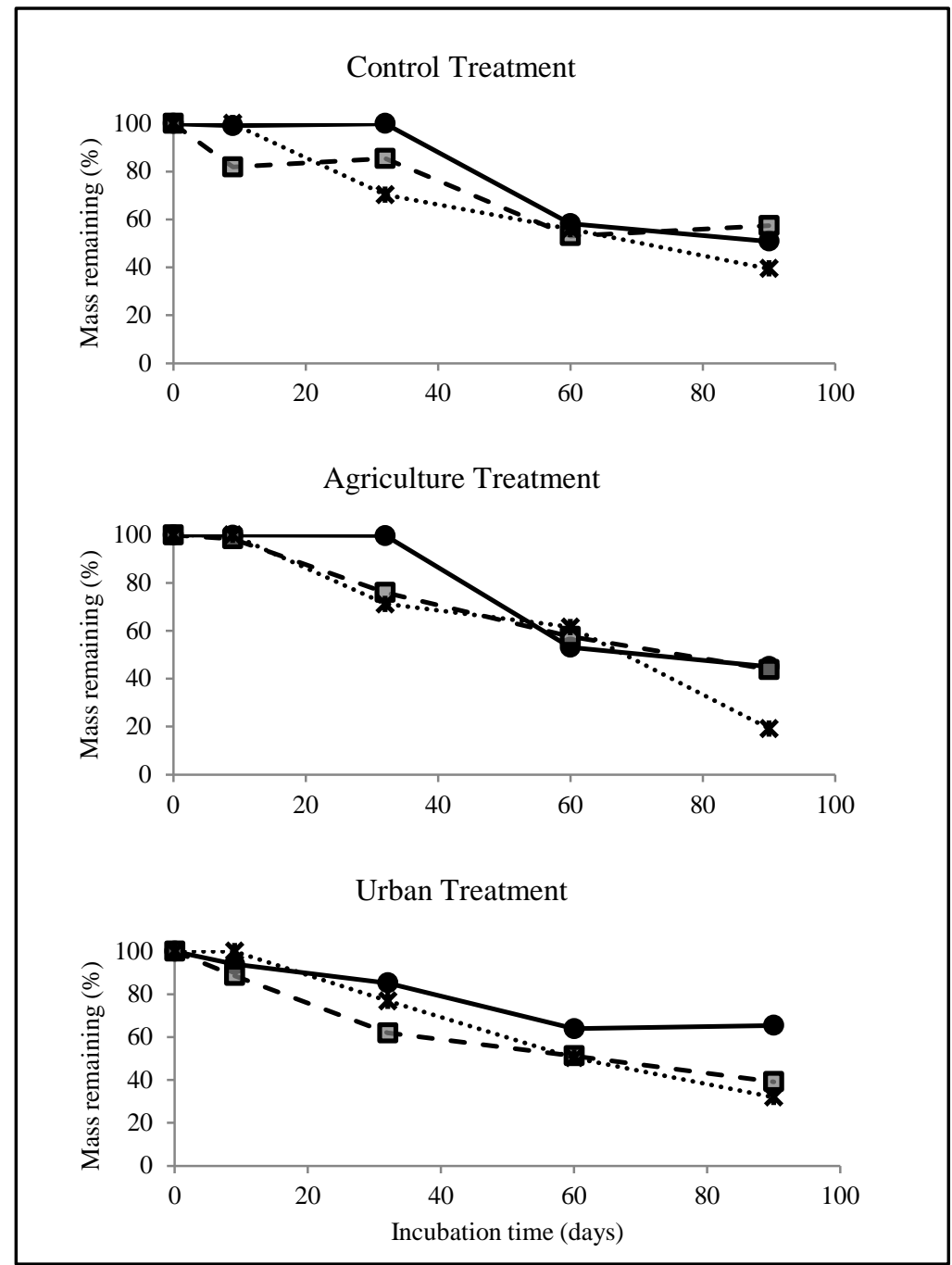

Figure 1-5. Leaf litter decomposition under three nutrient conditions (described in Methods) during July - October 2013. Leaf litter was incubated in mesh bags on the forest floor and subjected to tidal flow. Linear regression (not presented) was used to determine the number of days for $50 \%$ decay $\left(t_{50}\right)$. Circles represent block 1 , Squares represent block 2, Crosslines represent block 3. 
Table $1-2.50 \%$ decay rate $\left(t_{50}\right)$ as determined from a linear regression of litter decay (see Figure 1-4) and decay constant $(k)$ calculated from the exponential decay curve $X=X_{o} \mathrm{e}^{-}$ ${ }^{k t}$ with time $(t)$ set at the day that litter decay reached $50 \%$ of initial weight during the incubation period. There was no effect of nutrient treatment on $k$ values $(p=0.7)$.

\begin{tabular}{lcrl}
\hline Treatment & Block & $t_{50}$ & $k$ \\
\hline Control & 1 & 92 & 0.0075 \\
& 2 & 88 & 0.0079 \\
Agriculture & 1 & 71 & 0.0098 \\
& 2 & 82 & 0.0084 \\
& 3 & 76 & 0.0091 \\
Urban & 1 & 61 & 0.0114 \\
& 2 & 110 & 0.0063 \\
& 3 & 66 & 0.0105 \\
& 3 & 65 & 0.0107 \\
\hline
\end{tabular}




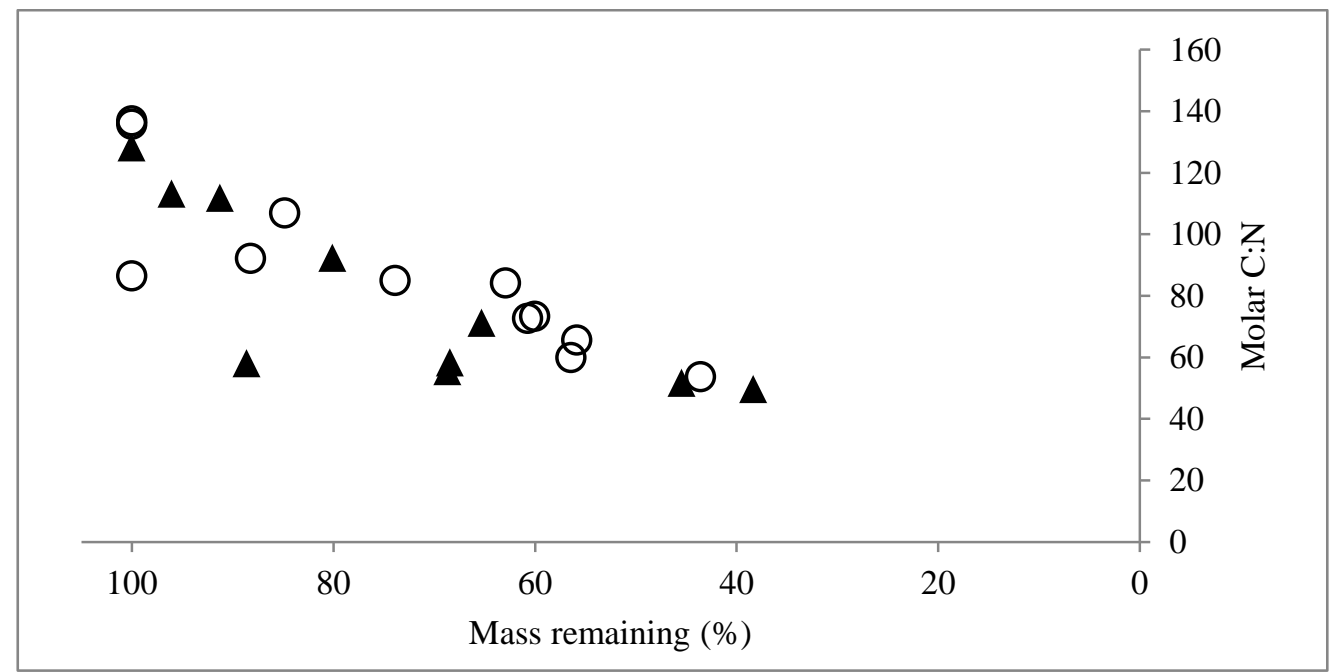

Figure 1-6. Molar C:N ratio of decaying leaf litter under the intermediate N:P fertilization treatment ("Urban," black triangles) and ambient conditions ("Control," open circles). Samples were collected from litter bags that had incubated on the forest floor from July to October 2013. Incubation time had a significant effect $(p<0.0001)$ on litter $\mathrm{C}: \mathrm{N}$ under both nutrient regimes. There was a small effect by nutrient treatment on litter $\mathrm{C}: \mathrm{N}(\mathrm{p}=0.07)$. 


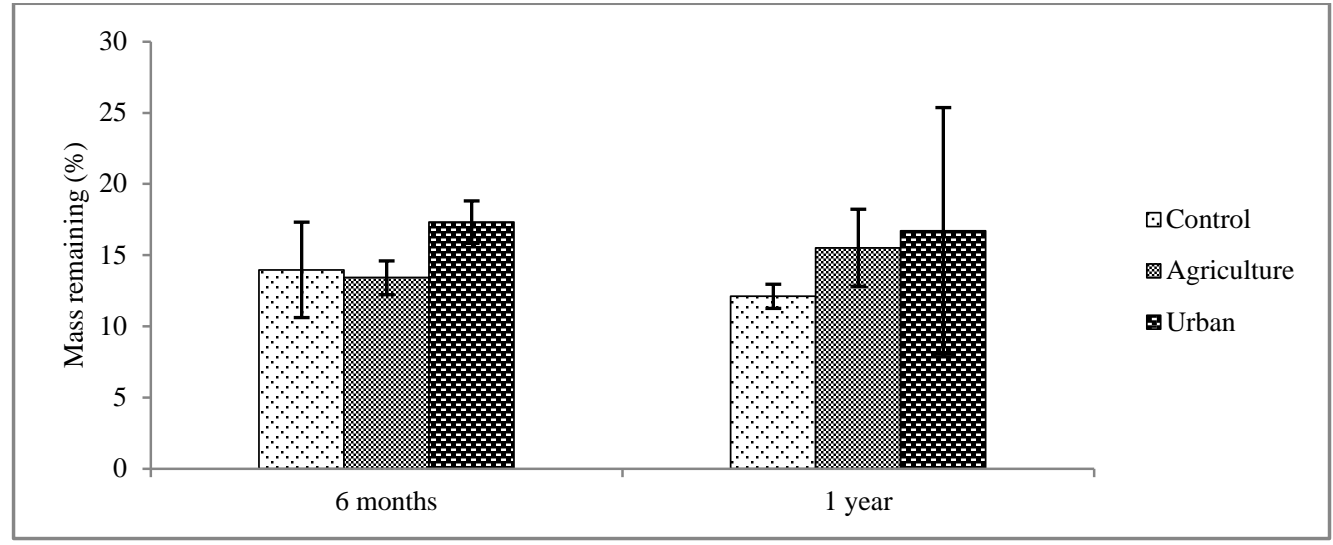

Figure 1-7. Percent mass remaining for below-ground mangrove leaf litter decomposition. The litter was buried at 5 to $15 \mathrm{~cm}$ depth in July 2012. Values are means across blocks $(n=3)$. Error bars indicate $+/-1$ S.E. Litter material recovered at 22 months past the burial date was integrated with fine root material and was considered fully degraded. 
Table 1-3. Reported values of litter decomposition (50\% decay rate $\left(t_{50}\right)$ and decay constant (k)) from mangrove systems across the world with classification (Lugo and Snedaker 1974). All studies used a form of the litter bag method to measure decomposition. If the decay constant $(k)$ was not reported in the study, I calculated it using the exponential decay curve $X=X_{o} \mathrm{e}^{-k t}$ with time $(t)$ set at the day that litter decay reached $50 \%$ of initial weight during the incubation period.

\begin{tabular}{|c|c|c|c|c|c|}
\hline $\begin{array}{c}\text { Study } \\
\text { location }\end{array}$ & $\begin{array}{l}\text { Mangrove } \\
\text { type/species }\end{array}$ & $\begin{array}{l}\text { Nutrients } \\
\text { added }\end{array}$ & $t_{50}$ & $\mathrm{k}\left(\right.$ day $\left.^{-1}\right)$ & Reference \\
\hline $\begin{array}{l}\text { Shenzhen, } \\
\text { China }\end{array}$ & Fringe: K. candel & Wastewater & 13 & 0.052 & Tam et al. (1998) \\
\hline & $\begin{array}{l}\text { Fringe: A. } \\
\text { corniculatum }\end{array}$ & Wastewater & $\begin{array}{l}48 \\
70 \text { to }\end{array}$ & $\begin{array}{l}0.015 \\
0.0048 \text { to }\end{array}$ & Aké-Castillo et al \\
\hline Mexico & $\begin{array}{l}\text { Fringe: } R \text {. mangle } \\
\text { Riverine: }\end{array}$ & None & $\begin{array}{l}144 \\
43 \text { to }\end{array}$ & 0.0084 & $\begin{array}{l}\text { (2006) } \\
\text { Twilley et al. }\end{array}$ \\
\hline Ecuador & Rhizophora spp. & None & $\begin{array}{l}231 \\
98 \text { to }\end{array}$ & $\begin{array}{l}0.003 \text { to } 0.016 \\
0.0042 \text { to }\end{array}$ & $\begin{array}{l}\text { (1997) } \\
\text { Twilley et al. }\end{array}$ \\
\hline Florida & Basin: R. mangle & $\begin{array}{l}\text { None } \\
\text { Spray }\end{array}$ & $\begin{array}{l}165 \\
61 \text { to }\end{array}$ & 0.0071 & (1986) \\
\hline Puerto Rico & Fringe: $R$. mangle & fertilizer & 110 & 0.006 to 0.011 & This study \\
\hline
\end{tabular}




\title{
Chapter 2
}

\section{EFFECT OF NUTRIENT ENRICHMENT ON ABOVE-GROUND PRODUCTION IN A PUERTO RICAN MANGROVE FOREST}

\author{
To be submitted to Aquatic Botany
}

\begin{abstract}
Brita J. Jessen ${ }^{\mathbf{1}}$, Ariel E. Lugo ${ }^{2}$, Ernesto Medina ${ }^{2}$, Candace Oviatt ${ }^{1}$, Jessica Foley ${ }^{3}$, Megan O’Connor ${ }^{4}$, Susanne Hoeppner, ${ }^{5,6}$, and Scott Nixon ${ }^{1 \dagger}$
\end{abstract}

1Graduate School of Oceanography; University of Rhode Island; 215 South Ferry Road; Narragansett, RI 02882

${ }^{2}$ International Institute of Tropical Forestry, U.S. Forest Service; San Juan, PR 00926

${ }^{3}$ University of Maryland Center for Environmental Science, Chesapeake Biological Laboratory, P.O. Box 38, Solomons, MD 20688

3

${ }^{5}$ Harvard Medical School; 25 Shattuck St.; Boston, MA 02115

${ }^{6}$ Department of Psychiatry, Massachusetts General Hospital, Boston, MA 02114

${ }^{\dagger}$ Deceased 


\title{
EFFECT OF NUTRIENT ENRICHMENT ON ABOVE-GROUND PRODUCTION IN A PUERTO RICAN MANGROVE FOREST
}

\begin{abstract}
Mangrove ecosystems are highly productive coastal wetlands that connect tropical terrestrial and marine systems. Increasing human populations and land use changes are enhancing nutrient loading to tropical coastlines, potentially leading to eutrophic conditions for marine systems. To better understand and predict the consequences of increased nutrient input, a fertilization study within a fringe mangrove system in southeast Puerto Rico was established to mimic high-nitrogen agriculture runoff (N:P ratio of 50:1) or urban runoff with higher phosphorus ( $\mathrm{N}: \mathrm{P}$ ratio of $16: 1)$ for an annual loading rate of $70 \mathrm{~g} \mathrm{~N} \mathrm{~m}^{-2} \mathrm{y}^{-1}$ and 3.1 or $9.7 \mathrm{~g} \mathrm{P} \mathrm{m}^{-2} \mathrm{y}^{-1}$. Bi-weekly pulses of fertilization began in October 2011 and continued for two years. Mangrove tree response was characterized by above-ground wood production and litterfall input. Basal area ranged from 17.1 to $32.7 \mathrm{~m}^{-2} \mathrm{~m}^{-2}$. Above-ground biomass (wood and foliage) ranged from 3.9 to $15.4 \mathrm{~kg}$ dry mass $\mathrm{m}^{-2}$. Mangrove above-ground growth was highly variable and was not affected by nutrient treatment. Litterfall was strongly seasonal, with higher rates associated with the start of the rainy season in late summer. Total litterfall for this fringe mangrove ranged from 1061 to $1217 \mathrm{~g}$ dry mass $\mathrm{m}^{-2} \mathrm{y}^{-1}$, which was on the higher range of neo-tropical fringe mangroves. Total litter production was not affected by nutrient treatment, but agriculture treatment (high $\mathrm{N}: \mathrm{P}$ ) enhanced leaf and stipule production ( $p=0.04$ and $2.2 \mathrm{e}^{-06}$, respectively). These results suggest that two years of high $\mathrm{N}: \mathrm{P}$ nutrient addition results in a small positive effect for above-ground production
\end{abstract}


within a fringe mangrove, and that litterfall may be a more sensitive response than aboveground biomass for a short-term (two years) assessment. Considering the different effects to mangrove production by the nutrient enrichment regimes (high vs. intermediate $\mathrm{N}: \mathrm{P}$ loading), further work is needed to assess $\mathrm{N}$ and $\mathrm{P}$ interactions that may affect aboveground mangrove production. 


\section{INTRODUCTION}

Mangrove forests are valuable coastal wetland habitats that provide ecosystem services on a local and global scale. Local benefits include shoreline stabilization, essential faunal habitat, organic material outwelling, nutrient and contaminant interception, and ecotourism (Alongi 2009). On a global scale, mangrove ecosystems are increasingly recognized as an important component of coastal carbon (C) sequestration via high rates of primary production and organic C retention (Donato et al. 2011; Kauffman et al. 2011; Bouillon 2011; Pendleton et al. 2012). Through these processes mangroves contribute a disproportionate amount of carbon capture per area: $12 \%$ of global coastal carbon burial is maintained by mangrove systems, which comprise just $0.5 \%$ of the world's coastal area (Alongi 2009). For a reciprocal perspective of mangrove C capture efficiency, Donato et al. (2011) calculate that the current global loss rates of mangrove habitat at $1-2 \%$ per year may be contributing 0.02 to $0.12 \mathrm{Pg} \mathrm{C} \mathrm{yr}^{-1}$ of carbon emissions. On either scale of local ecosystem services or global budgeting, mangrove system resiliency and function are dependent upon within-stand C cycling.

The amount of $\mathrm{C}$ stored within a coastal wetland system is based on ratios of production, decomposition, and belowground biomass allocation (and to a variable extent, C deposition and outwelling). Studies in temperate coastal wetlands have shown that cultural nutrient enrichment can alter these components of within-stand C cycling along bi-directional pathways: While above-ground production may be enhanced by added nutrients (Turner et al. 2009), other altered processes such as greater organic material decomposition and a reduction of below-ground biomass can lead to a destabilization of structural peat and eventual habitat loss (Turner et al. 2009; Deegan et 
al. 2012). Recently, tropical coastlines have been subject to accelerating cultural nutrient input (Downing et al. 1999; Corredor et al. 1999), with nitrogen (N) and phosphorus (P) promoting significant change in coastal ecosystems such as shifting community composition, increased hypoxic events, or changes in the productivity regime (Rabalais and Nixon 2002; Valiela 2006; Nixon and Fulweiler 2009) Strong trends of population growth in tropical urban regions (Martinuzzi et al. 2009) are associated with greater availability of nutrients via sewage effluent, impervious surface coverage, and nitrogenous combustion products (Ortiz-Zayas et al. 2006). Land-use change in tropical settings is exemplified by the amount of inorganic fertilizer consumption in Latin America and the Caribbean, which increased over 1500\% during the past five decades (IFIA 2015). Previous work on the effects of nutrient enrichment for temperate coastal wetlands (Valiela et al. 1976, Deegan et al. 2006, Darby and Turner 2008) are useful as a reference but not as a predictive model for tropical coastal system response to altered nutrient conditions. Complimentary studies are now needed to understand and predict ongoing change to the $\mathrm{C}$ cycle within tropical vegetated coastlines.

Autochthonous production is an important component of the mangrove $\mathrm{C}$ cycle, and can be the main source of below-ground C storage (Bouillon et al. 2003; Bouillon et al. 2008; Kristensen et al. 2008). A standard metric of mangrove productivity is litter production (Pool et al. 1975; Day et al. 1987; Twilley et al. 1986; Woodroffe et al. 1988), which also allows researchers to identify seasonal or inter-annual trends of mangrove leaf production and reproduction efforts. In addition to litter production, species-specific allometric equations that are typically based on stem diameter and/or tree height have been developed to estimate biomass components and growth rates (Sherman et al. 2003; 
Smith and Whelan 2006; Komiyama et al. 2008). The combination of litter production and allometrically-derived biomass estimates are useful methods for a non-destructive estimate of standing biomass, growth rates, and organic C flux estimates.

A standard method to investigate the effects of nutrient enrichment on ecosystem function is by experimental nutrient supplement within a relatively unencumbered (often described as pristine) ecosystem (salt marsh: Valiela et al. 1976, Deegan et al. 2007; seagrass: Short 1987; lake: Schindler et al. 1971). The majority of mangrove nutrient enrichment field studies have been conducted using buried fertilizer (Boto and Wellington 1983; Feller 1995; Feller et al. 2003; Lovelock et al. 2009). The benefit of this method is that fertilizer is not lost by tidal action or volatilization, but a limitation is that the added nutrients are not first encountered and modified by the microbial community or biogeochemical context on the surface of the forest floor (Whigham et al. 2009). Anthropogenic nutrients are often transported to coastal ecosystems via water channels (Howarth et al. 1996) and are likely to interact with components of the intertidal system differently compared with belowground cores of fertilizer (Deegan et al. 2007). Therefore, this study measures mangrove production response to surface-level aqueous nutrient application to more closely mimic current-day anthropogenic nutrient input.

The main purpose of this study is to report on mangrove above-ground production under two years of periodic nutrient enrichment with three scenarios of nutrient enrichment: high $\mathrm{N}: \mathrm{P}$ (50N:1P), intermediate $\mathrm{N}: \mathrm{P}$ (16N:1P), and control (ambient channel water). High $\mathrm{N}: \mathrm{P}$ fertilizer represents nutrient input from agriculture sources (sugarcane watershed drainage $\mathrm{N}: \mathrm{P}=43.9$; Faithful et al. 2007), and intermediate $\mathrm{N}: \mathrm{P}$ fertilizer represents nutrient input from urban sources (urban drainage $\mathrm{N}: \mathrm{P}=12.6$; 
Hopkinson and Day 1980). The rate of $\mathrm{N}$ addition is equivalent for both fertilization scenarios, with P addition altered for the appropriate ratio (see Methods). Fertilizer is applied on a plot-level $\left(4 \mathrm{~m}^{2}\right)$ scale every-other week to mimic pulsing events by aqueous flow. Two commonly-used measures of production are reported to assess mangrove production: litter production from the mangrove canopy, and estimates of standing biomass based on allometric relationships. The following questions are addressed by this study:

1. Do mangrove above-ground biomass growth rates change under different levels of cultural nutrient enrichment?

2. Is there a discernable change in quantity or composition of mangrove litter production under nutrient enrichment?

As fringe mangroves are primarily N-limited (Reef et al. 2010), I expected that mangrove trees would respond to agriculture and urban treatments with increases in above-ground production over the two-year enrichment period. Keeping in mind that the diametric growth of mangrove stems may not be observable within two years of nutrient enrichment, I anticipated that an increased trend of litter production (Boto and Wellington 1983; Feller 1995; Feller et al. 2003) would be more evident. 


\section{METHODS}

\section{Study site}

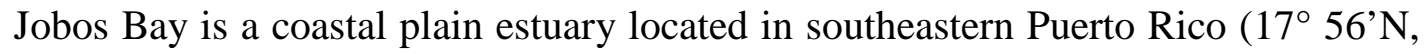
$\left.66^{\circ} 13^{\prime} \mathrm{W}\right)$. The mouth of the bay is mainly enclosed by mangrove-fringed limestone cays extending from a barrier coral reef. The local tidal cycle is mixed diurnal and ranges from 17 to $36 \mathrm{~cm}$, with the largest tides in October (Field 2008). The average residence time of the bay 5.5 days, with surface water entering through the cay channels, flowing north into a series of channels (Mar Negro) or clockwise through the northeast cove, and exiting as bottom water through the western opening of the bay (Capella 2008).

The region is classified as Subtropical Dry Forest Life Zone (Ewel and Whitmore, 1973), with an average annual temperature of $26^{\circ} \mathrm{C}$ (range $24.3^{\circ}$ to $27.5^{\circ}$ ) and average annual rainfall of $980 \mathrm{~mm}$. While there is no strong seasonal component for air temperature, precipitation exhibits a seasonal trend with a dry season from January to April and a rainy season from June to November (see Appendix). This seasonal trend drives intermittent freshwater flow to Jobos Bay via small rivers, but surface freshwater flow is considered negligible (Bowen and Valiela 2008). It is proposed that two sources of groundwater supply freshwater to the fringing mangrove forests: a shallow (3 to $23 \mathrm{~m}$ deep) mainland source, and a deeper source (24 to $42 \mathrm{~m}$ deep) that flows under the bay to the outer cays (Zitello et al. 2008; Capella 2008).

The Jobos Bay watershed is a mixed landscape of agriculture, low-density urban communities, and several industrial facilities including two electrical power production plants and a petroleum refinery (see Zitello et al. 2008). Historically, sugar cane plantations dominated the region from Spanish Colonial times to the mid-20th century. 
Much of the Jobos Bay coastline is now under protection status: the Jobos Bay National Estuarine Research Reserve (JBNERR) was established in 1981 and spans 1,133 ha of the northern coastline and much of the cays. The eastern coastline and two eastern-most cays are under the domain of the Aguirre State Forest (2,390 ha).

The location of this study is a fringe (sensu Lugo and Snedaker 1976) mangrove wetland positioned at the most southeastern channel of the bay (Figure 2-1), within the domain of the Aguirre State Forest. We selected this location as the least anthropogenically affected site for Jobos Bay, having the greatest distance from anthropogenic land use and constant seawater flow from the relatively low-nutrient Caribbean (NERRS 2015; Appendix). Additionally, stable isotope work by Bowen and Valiela (2008) has demonstrated that rooted vegetation at sites within Jobos Bay are largely disconnected from anthropogenic nitrogen sources due to low hydrologic connectivity.

The mangrove stand at our study site follows a typical neo-tropical zonation pattern: Rhizophora mangle (L.) dominates the coastal edge with intermittent white mangrove (Laguncularia racemosa (L.) c.f. Gaertn.) stems. A transition zone of thin, densely packed $R$. mangle leads to an Avicennia germinans monoculture stand upland. The $R$. mangle coastal edge zone of the extends approximately 10-15 m upland of the subtidal region. The average canopy height is $4.24 \mathrm{~m}$ (range 0.76 to $7.09 \mathrm{~m}$ ) and the average diameter at breast height (1.3 $\mathrm{m}$ above the forest floor) is $5.26 \mathrm{~cm}$ (maximum $21.7 \mathrm{~cm})$. 


\section{Experiment design}

Three replicate blocks were established within the mangrove forest with at least 100 $\mathrm{m}$ spacing. The blocks were positioned parallel to the coastline and $5 \mathrm{~m}$ inland from the coastal edge. Each block contained three $4 \mathrm{~m}^{2}$ quadrats (“experimental units”) with at least $3 \mathrm{~m}$ of buffer spacing between the units. Extensive personal observations concluded that flood water above the mangrove platform did not flow laterally between experimental units, but mainly flowed in a north-south (upland-channel) direction via tidal forcing. Dense canopy coverage also limited surface water mixing above the mangrove floor by deflecting wind.

The experimental units were randomly assigned a nutrient treatment (ambient; high nitrogen/low phosphorus fertilization; high nitrogen/moderate phosphorus fertilization) applied every-other week for two years beginning October 2011. The treatments were applied by hand with a pressurized sprayer, with care taken to ensure that the spray was applied evenly within the quadrat and positioned close to the forest floor to limit volatilization. When possible, treatments were scheduled to coincide with low tides. Ambient treatment was $1 \mathrm{~L}$ of offshore channel water collected at the time of fertilization. Fertilized treatment was $1 \mathrm{~L}$ of locally-collected channel water with dissolved ammonium chloride and potassium phosphate, for an annual fertilization of 70 $\mathrm{g} \mathrm{N} \mathrm{m}^{-2} \mathrm{y}^{-1}$ and $3.1 \mathrm{~g} \mathrm{P} \mathrm{m}^{-2} \mathrm{y}^{-1}$ (“agriculture” high $\mathrm{N}: \mathrm{P}$ fertilizer) or $70 \mathrm{~g} \mathrm{~N} \mathrm{~m}^{-2}$ and $9.7 \mathrm{~g}$ $\mathrm{P} \mathrm{m}^{-2}$ ("urban" intermediate N:P fertilizer). With an estimate that the experimental area is submerged by $10 \mathrm{~cm}$ of tidal water for half of the year (based on tidal inundation data, Appendix), the nutrient loading rate of this study is approximately 30 times the amount of DIN loading by tidal overflow (NERRS 2015; Appendix). An estimate of P loading 
increase is difficult to make because channel water phosphate levels were below the detection limit over 80\% of the experiment time period (NERRS 2015).

\section{Sampling}

Tree identification and measurement

Each mangrove tree with at least one aerial root or set of pneumatophores located on the edge or within one of the $4 \mathrm{~m}^{2}$ experimental units was tagged, characterized, and measured before the start of the experiment (July - October 2011) and at the end of the experiment (August - October 2013). Tags were securely placed on the main stem to mark the appropriate level for repeated measurements of each tree.

Basal area and stem density

Basal area $(b a)$ is defined as the amount of forest floor that is occupied by stem growth. To calculate a plot basal area, individual trees were measured for the diameter at breast height (DBH), which is $1.3 \mathrm{~m}$ above the forest floor. The $b a$ was calculated from the DBH assuming a cylindrical shape of the tree stem:

$$
b a=\pi(\mathrm{DBH} / 2)^{2}
$$

The stand basal area (stand $b a$ ) is the sum of individual stem basal areas divided by the total area measured (in this case, the experimental plot area, or $4 \mathrm{~m}^{2}$ ):

$$
\text { Stand } b a=\frac{\sum b a_{\mathrm{i}}}{\mathrm{A}}
$$

Where $b a_{\mathrm{i}}$ is the basal area of each tree within the plot, and $\mathrm{A}$ is the plot area.

Due to the serpentine-like structure or multiple branching of the mangrove trees, the classical DBH measurement was adjusted in the following ways: 
- Four of the 78 trees measured had multiple stems that branched at the tree base. Following Clough et al. (1997), each stem was treated as an individual tree for biomass estimates only.

- If a fork, unusual growth, or termite nest occurred at $1.3 \mathrm{~m}$, a measurement was made adjacent to the irregularity at a point that best represented the typical diameter of the stem.

Stem density (number of trees $/ \mathrm{m}^{2}$ ) was determined by the number of live trees with main stems that were contained (or had at least $50 \%$ of the basal area) within an experimental unit perimeter.

The assumption was made that each experimental block had the same basal area and stem density; thus, the calculated basal area and stem densities for each experimental unit within a block was averaged $(n=3)$ for a whole-block value.

\section{Above-ground biomass}

Several allometric relationships have been developed to estimate mangrove biomass for above- and below-ground components of different species (Sherman et al. 2003; Smith and Whelan 2006; Komiyama et al. 2008). I selected the relationship by Smith and Whelan (2006) developed in southern Florida because of the close geographical area, a similar range of main stem diameter, and the sole use of $\mathrm{DBH}$ rather than $\mathrm{DBH}$ plus tree height, which is difficult to accurately measure without felling. Using Smith and Whelan (2006), above-ground dry biomass was calculated using the following allometric relationship of dry biomass and $\mathrm{DBH}$ of $R$. mangle and L. racemosa:

$$
\log _{10} \mathrm{y}=\mathrm{a} \log _{10}(\mathrm{DBH})+\mathrm{b}
$$

where $\mathrm{y}=$ aboveground dry biomass in $\mathrm{kg}$ and $\mathrm{DBH}$ is in $\mathrm{cm}$ 
The following constants were used with the above equations (Smith and Whelan 2006):

\begin{tabular}{lcc}
\multicolumn{1}{c}{ Species } & Slope constant (a) & Interept constant (b) \\
\hline R. mangle & 1.731 & -0.112 \\
L. racemosa & 1.930 & -0.441
\end{tabular}

I assumed a constant growth rate during the experimental period; therefore, above ground biomass differences between 2011 and 2013 were divided by 2 years for an annual growth rate. The mean annual change in above-ground biomass within an experimental unit (g dry weight stem ${ }^{-1}$ year $^{-1}$ ) was multiplied by the stem density of the corresponding block (stem count $\mathrm{m}^{-2}$ ) for an area-based value.

\section{Tree height}

The height of individual trees was measured using a graduated telescoping pole and three sets of eyes (two people directly under the tree and one at a distance away). The total height of each tree was determined as the linear distance from the forest floor to the highest point of the tree canopy.

\section{Litter production}

Two $0.25 \mathrm{~m}^{2}$ litter collection baskets were established for each experimental unit, one located in the center of the quadrat, and one sited under tagged trees with canopies that extended beyond the quadrat perimeter. The baskets were constructed with fiberglass window screen mesh and wire framing and mounted on PVC poles at approximately $50 \mathrm{~cm}$ above the forest floor (above the highest tide level). Mangrove material captured by the baskets was collected every-other week. The samples were placed in plastic bags and kept cool until they were brought to the laboratory, then transferred to paper bags and placed in a drying oven at the $65^{\circ} \mathrm{C}$ for at least one week. 
The dried samples sorted by category (leaves, stipules, flowers, propagules, wood, unidentified material) and re-dried to a constant weight for dry mass measurement. Stipules, propagules, and R. mangle flowers were counted as well as weighed.

Litter material collected by duplicate litter collection baskets were averaged by experimental unit, scaled from $0.25 \mathrm{~m}^{2}$ to $1 \mathrm{~m}^{2}$, and divided by the number of days elapsed between each collection for a daily litterfall rate.

Stipule fall is a sensitive indicator of leaf production (Boto and Wellington 1983). Following the work by Boto and Wellington (1983), stipule fall count for the experimental period was summed for each collection basket and averaged (2 replicates) per experimental unit. A linear regression (stipule count by days of experimental nutrient enrichment) was performed for each unit. As there was only one replicate per treatment level within blocks, it was assumed that a block effect was insignificant.

\section{Data analyses}

Mangrove annual above-ground growth was evaluated with a two-factor analysis of co-variance (ancova) with blocking effect and initial (2011) above-ground biomass as a cofactor. To test whether nutrient treatment affects the rate of stipule fall over the experimental period, a one-factor analysis of variance (anova) was used. For this test, it was assumed that blocking had no effect (see above). Mangrove litter production (total litter and leaves, stipules, and reproductive components) was evaluated using a two-factor repeated measures analyses of variance (anova) with blocking and treatment*year interaction for total and component annual litterfall. The reproductive structure (propagules and flowers) component presented high variance that skewed the residual homogeneity of variance; therefore a log-transformation was performed on the data for 
analysis. As the total and component litterfall production rates are related, a family-wise adjustment of error rates is typically performed; however, with few replicates (6 baskets per treatment per year), the design power is too low to detect significant results with this transformation. Therefore p-values were maintained at 0.05. For all analyses, when significant differences were presented a post-hoc Tukey honest significant test was used to evaluate pair-wise differences between factors.

Cumulative stipule analysis was conducted in R (v 3.1.1) with the "Stats" package. All other analyses were conducted with SAS (v. 9.3).

\section{RESULTS}

Differences in mangrove tree characterization between the three blocks demonstrate the variation of forest structure within a continuous mangrove stand. Stem density was lowest at block $2\left(0.9\right.$ stems $\left.\mathrm{m}^{-2}\right)$ and highest at block $3\left(1.2\right.$ stems $\left.\mathrm{m}^{-2}\right)$. Basal area increased slightly over the two-year observation period across all blocks (Table 2-1). Block 2 had the lowest basal area (17.1 to $17.9 \mathrm{~m}^{-2} \mathrm{~m}^{-2}$ ) and block 3 had the highest basal area (31.6 to $32.7 \mathrm{~m}^{-2} \mathrm{~m}^{-2}$ ). Tree height ranged from 3 to $5 \mathrm{~m}$, and the average stem diameter was between 3 and $6 \mathrm{~cm}$ (Table 2-2). Above-ground biomass varied several fold between quadrats within blocks, ranging from 3.9 to $14.7 \mathrm{~kg} \mathrm{DW} \mathrm{m}^{-2}$ in 2011 and 4.8 to $15.4 \mathrm{~kg} \mathrm{DW} \mathrm{m}^{-2}$ in 2013 (Table 2-2). Annual above-ground biomass production rate of was highly variable between and within and between blocks of the mangrove stand (Figure 2-2). There was no significant effect of nutrient treatment on above-ground biomass change $(p=0.4)$ : quadrats that presented the lowest $\left(0.2 \mathrm{~kg} \mathrm{~m}^{-2} \mathrm{y}^{-1}\right)$ and highest $\left(0.6 \mathrm{~kg} \mathrm{~m}^{-2} \mathrm{y}^{-1}\right)$ average biomass growth were both under agriculture nutrient enrichment. 
Average annual litterfall across the two observation years was $1061 \mathrm{~g} \mathrm{~m}^{-2} \mathrm{y}^{-1}$ under control treatment; $1217 \mathrm{~g} \mathrm{~m}^{-2} \mathrm{y}^{-1}$ under agriculture treatment, and $1167 \mathrm{~g} \mathrm{~m}^{-2} \mathrm{y}^{-1}$ under urban nutrient treatment. Total litterfall was strongly seasonal (Figure 2-3); however, the timing of litter production peaks and troughs was different between observation year 1 (Oct. 2011 to Oct. 2012) and observation year 2 (Oct. 2012 to Oct. 2013). For observation year 1, the lowest litter production rate occurred between December and April, with a peak in June through August. Low production rates in year 2 occurred around the same time as year 1 (November to April), but the litter peaks were delayed until late July.

There was no overall treatment effect for total litterfall production rates $(\mathrm{p}=0.6)$ and no treatment effect in observation year $1(\mathrm{p}=0.3)$; however, there was a slight difference in treatments for observation year 2, with production under agriculture treatment (3.31 $\mathrm{g}$ dry mass $\mathrm{m}^{-2} \mathrm{~d}^{-1}$ ) different than urban and control production rates (2.44 to 2.47 g dry mass $\mathrm{m}^{-2} \mathrm{~d}^{-1} ; \mathrm{p}=0.06$ and 0.07 , respectively; Figure 2-4A and Table 2-3). Neither agriculture nor control treatment effects on total litter production were strongly different between observation years, but litter production under urban nutrient enrichment was significantly different between observation years $(p=0.04)$, due to the high propagule and flower production in observation year 1 (Figure 2-4C).

There was an overall treatment effect on the leaf component of litterfall rate $(\mathrm{p}=$ 0.04; Table 2-3) with higher leaf production under agriculture nutrient enrichment compared with control (year $1 \mathrm{p}=0.03$; year $2 \mathrm{p}=0.05$ ) and slightly higher leaf production compared with urban nutrient enrichment (year $1 \mathrm{p}=0.05$; year $2 \mathrm{p}=0.1$ ). Leaf production under urban nutrient enrichment was not significantly different from 
control in either observation year $(p=0.6$ to 0.8$)$. There was no significant difference in leaf production rates between observation years 1 and 2 under any nutrient condition (Figure 2-4B).

The reproductive component of litterfall (propagules and flowers) showed strong variation between observation years (Figure 2-4C). Reproductive components were highest under urban nutrient enrichment in year 1, but the highest reproductive component production switched to agriculture nutrient enrichment in year 2 (treatment*year interation $\mathrm{p}=0.002$; Table 2-3). There was a slight overall treatment difference in flower and propagule production for observation year 1 only ( $p=0.07$ ), with a significant difference between agriculture and urban treatments $(\mathrm{p}=0.03)$.

Nutrient treatment significantly impacted stipule production rate $(\mathrm{p}=0.03)$, with a slight treatment*year effect ( $p=0.06$; Figure 2-4D and Table 2-3). In observation year 1 , stipule production under agriculture nutrient enrichment was different compared with control $(p=0.009)$ and urban nutrient treatment $(p=0.005)$. In observation year 2 , there was a smaller difference stipule production between agriculture and control treatments (p $=0.05$ ), and no significant difference of stipule production between agriculture and urban enrichment treatments $(p=0.3)$. Stipule production rates under urban and control were not significantly different for either observation year $(p=0.3)$. Cumulative stipule fall across the study period was significantly enhanced by agriculture nutrient treatment $(\mathrm{p}=$ $2.19 \mathrm{e}^{-06}$ ), while urban nutrient enrichment had no difference compared with production under control conditions (Figure 2-5).

A comparison of all litter components demonstrates the dominance of leaves and reproductive parts (propagules and flowers) across all treatments and seasons (Figures 2- 
4 and 2-6). Twigs and unidentified organic matter constituted a small and intermittent proportion of the litter input. Leaves were the major factor of litter production at $70 \%$ or greater of the dry weight for the majority of the two-year measurement period (Figure 26). The period of greatest reproductive effort typically coincided with peak litter production periods (late summer into early fall).

\section{DISCUSSION}

\section{Above-ground biomass and growth}

On a global scale, mangrove biomass is inversely related with latitude (Saenger and Snedaker 1993). At the latitude of this study site $\left(18^{\circ} \mathrm{N}\right)$, biomass range is reported to be 5 to $63 \mathrm{~kg}$ dry mass $\mathrm{m}^{-2}$ (Alongi 2009). Biomass estimates from this study range from 4.2 to $15.4 \mathrm{~kg}$ dry mass $\mathrm{m}^{-2}$ (Table $2-2$ ), which is on the lowest end of the global range. These values reflect the importance of local environmental conditions such as freshwater input, nutrient availability, and tidal flow within the global reference frame. On a protected fringe mangrove site at the Mar Negro lagoon in northern Jobos Bay, Lugo et al. (2007) measured canopy height up to $9 \mathrm{~m}$ compared with a maximum average height of $5.5 \mathrm{~m}$ at this study site in the southern cays. Environmental differences between these sites include sources of groundwater and river input (low to negligible at the cay site of this study) and wind exposure (higher at the cay site), which are likely to affect aboveground production and structure. There is also a strong difference of inorganic nutrient levels between Mar Negro and the southern cays; ammonium levels in Mar Negro waters are approximately 12 to $15 \mu \mathrm{M}$, compared with 2 to $6 \mu \mathrm{M}$ DIN concentration for channel water at the cay site (Appendix). In contrast to a two-year nutrient enrichment 
experiment, the high nutrient levels at Mar Negro have existed for decades as a result of local septic systems, large-scale agriculture, and slow turnover of the lagoon (Lugo et al. 2007, Zitello et al. 2008). While a comparison of these two sites within Jobos Bay is made difficult given a several different environmental and resource conditions between the sites, it is a recommended next step to better understand mangrove production within long-term nutrient gradients.

There was no effect of nutrient enrichment on annual above-ground standing biomass change within any of the blocks, due in part to high variability of initial standing mass. I suspect DBH-based allometric measurements for mangrove biomass may be affected by changes in seasonal water uptake (Vandegehuchte et al. 2014) or small differences in readings by multiple field workers. However, it is likely that two years is not an appropriate period to observe a measurable difference in slow-turnover components such as above-ground woody biomass. Mangrove leaf turnover rates range from 6 months to 1 year (Pool et al. 1975), therefore litter production is likely to be a more sensitive indicator of nutrient uptake and use.

\section{Litter production}

In contrast to the relatively low standing biomass values, the range of annual average litter production measured for this study (1061 to $1217 \mathrm{~g}$ dry mass $\mathrm{m}^{-2} \mathrm{y}^{-1}$ ) was on the high range for fringe mangroves in the Caribbean and Latin America (480 to 1690 g dry mass $\mathrm{m}^{-2} \mathrm{y}^{-1}$; Table 2-4) and close to the median of global mangrove litter production (130 to $1870 \mathrm{~g} \mathrm{DW} \mathrm{m}^{-2} \mathrm{y}^{-1}$; Saenger and Snedaker 1993). Mangrove litter production is related to forest structure classification (Lugo and Snedaker 1974), latitude (Saenger and Snedaker), and environmental conditions such as temperature, rainfall, and 
interstitial salinity (Day et al. 1996). Lugo et al. (2007) reported a higher litterfall rate (1690 g dry mass $\left.\mathrm{m}^{-2} \mathrm{y}^{-1}\right)$ at a fringe mangrove site in the Mar Negro lagoon of northern Jobos Bay. As described for above-ground biomass, higher litter production of the Mar Negro mangroves may be related to greater amounts of freshwater delivery via groundwater and river discharge.

The strong seasonal pattern of the total litter production (Figure 2-3) agrees with previous work (Twilley et al. 1986; Tam et al. 1998; Lugo et al. 2007). Twilley et al. (1986) measured greater litter production in a basin mangrove during the same period as found in this study (August to October), which they link with soil salinity levels. This explanation is unlikely for a fringe system that is regularly flushed by tides and therefore maintains a consistent interstitial salinity. Tam et al. (1998) report peak litter fall during the summer rainy season, and Lugo et al. (2007) reported a spike in litter production after a significant rainfall event. It is possible that increased energy associated with storms would enhance the litter fall. Peak litter fall in this study corresponded with the rainy season; however, there was no relationship between monthly litter production and total monthly rainfall (data not shown).

In addition to seasonal variation, inter-annual differences of litter production were observed, particularly for reproductive components (propagules and flowers; Figure 2-4). Inter-annual fluctuations of litter reproductive components has also been previously observed: Steinke and Ward (1988; as reported by Tam et al. 1998) measured rates of high propagule production followed by a drop in production within Avicennia marina stand. Woodroffe (1982) also reported significant variation in propagule production. 
These works demonstrate the importance of multi-year studies for stand-level dynamics that may be missed by short-term observations.

The stand canopy of this fringe mangrove is dense and interwoven, with canopies from mangroves located outside of the experimental unit extending over the study sites. Therefore litter collection baskets were receiving litter from the targeted trees as well as outside trees. My attempt to mitigate this confounding factor was to place one litter basket in the center of the experimental unit and one basket outside the unit but strategically placed to receive litter from experimental trees. Work by Feller and colleagues $(2003,2007)$ employed a more sensitive technique to observe mangrove tree response to nutrient enrichment by examining stem branching and apical bud production. Although some signal of enhanced litter production was detected through the litter catch, it may have been diluted by neighboring trees.

Mangrove production response to nutrient enrichment scenarios is evidently sitespecific (Table 2-5), which may be due to within-system interactions of biotic (e.g., mangrove species, herbivore pressure, benthic microbial activity) and environmental (e.g., salinity, benthic redox status, background nutrient availability) factors (Twilley and Rivera-Monroy 2005; Reef et al. 2010). N limitation relief appeared to enhance aboveground production within a fringe mangrove in northern Australia (Boto and Wellington 1983), and within fringe and dwarf mangrove stands in Florida (Feller et al. 2003; Whigham et al. 2009). However, by stimulating a reduction of below-ground root structure (which limited water uptake), $\mathrm{N}$ enrichment enhanced mortality rates of a drought-stricken scrub forest (Lovelock et al. 2009). For studies that applied distinct scenarios of $\mathrm{N}$ or $\mathrm{P}$ enrichment, the two nutrients appeared to function in reciprocal 
patterns at the site level: where $\mathrm{N}$ enrichment stimulated production or mortality, $\mathrm{P}$ enrichment had no effect (Boto and Wellington 1983; Feller et al. 2003; Lovelock et al. 2009). Correspondingly, sites that responded to P limitation relief showed no effect with N enrichment (Boto and Wellington 1983; Feller 1995). The previous only study that applied both $\mathrm{N}$ and $\mathrm{P}$ on a plot scale (versus individual tree targeting) by wastewater discharge found no effect on litter production (Tam et al. 1998).

In contrast, this study found enhanced stipule and leaf production under agriculture (high N:P) but not urban (intermediate N:P) nutrient enrichment (Figures 2-4 and 2-5). As previous work has demonstrated that fringe mangroves are primarily $\mathrm{N}$-limited (works above and Reef et al. 2010), it is surprising that the two nutrient treatments with the same amount of $\mathrm{N}$ enrichment had different effects. These results suggest an interaction of $\mathrm{N}$ and P (either directly or indirectly) that affects mangrove production. Further investigation into foliar nutrient concentrations and nutrient use efficiencies is currently ongoing and may provide more insight into the effect of $\mathrm{N}: \mathrm{P}$ ratio on mangrove productivity.

Results of ecosystem-based manipulative studies are conditioned on the duration of the experiment as well as the scale of the modified area. The goal of this study was to simulate nutrient delivery by enriched tidal waters that overflow an area of mangrove forest rather than a targeted nutrient addition for individual trees (Feller et al. 2003, Whigham et al. 2009). However, this delivery method may require a long-term enrichment for measurable results within slow-turnover biomass. Floodwater application of nutrient enrichment in a temperate salt marsh had a lag period of at least 2 years before system-wide effects were observed (Deegan et al. 2007) Additionally, a wider coverage 
area may be required for an observable effect by the mangrove trees. While all trees considered by this study had at least one above-ground root or pneumatophore within the $4 \mathrm{~m}^{2}$ experimental plot, nearly all of the studied trees had multiple above-ground roots extending outside of the experiment unit, which may reduce the strength of the nutrient enrichment.

\section{CONCLUSION}

The results from this study suggest that within a short encounter (two years) of nutrient enrichment, high N:P fertilization can enhance litter production. However, fertilizer with the same amount of $\mathrm{N}$ but greater $\mathrm{P}$ appeared to have little overall effect on litter production, though a one-year spike in reproductive components was observed. This differential effect of N:P input requires further examination to understand the mechanisms involved. In contrast, above-ground biomass composed of wood and foliage did not respond to nutrient enrichment within two years. It is possible that this slowturnover biomass component requires a longer duration of nutrient amendment before a measurable response is found.

Mangrove system response to nutrient enrichment can depend on geographic location, environmental setting (riverine, fringe, scrub), nutritional status of the mangrove (N- or P-limited), and other environmental factors (e.g., soil salinity). Much of our current knowledge on mangroves and added nutrients is based on work that focused on stunted mangrove trees, which are likely to be strongly nutrient limited and/or saltstressed (Lovelock et al. 2009) and may have a more profound or rapid respond to nutrient treatment. For a more complete understanding of a rapid and continuing trend in 
tropical coastal wetlands, I recommend additional field-based manipulation studies of nutrient enrichment in mangrove systems within different ecosystem settings on a multiyear time scale, as well as research on mangrove production along a nutrient gradient (e.g., southern to northern Jobos Bay).

\section{ACKNOWLEDGEMENTS}

This project was successful due to the support by scientists and managers at the Jobos Bay National Estuarine Research Reserve and the International Institute of Tropical Forestry. Our industrious team members were Laura Almodovar, Juan Pablo Alvarez Rosario, Laura Caicedo-Quiroga, Chelsea Duball, Ishamari Colon, David Johnson, Sandra Schleier Ryan Quinn, and Vuarnelle Urena. I would like to thank Dr. Kiersten Curti for her assistance with statistical analyses. This work was funded by a grant from the U.S. Forest Service/International Institute of Tropical Forestry (agreement no. 10-CA-11120101-026), The Nature Conservancy Global Marine Initiative, the National Oceanic and Atmospheric Administration's (NOAA) Puerto Rico Sea Grant, Rhode Island Sea Grant, and the NOAA - National Estuarine Research Reserve graduate fellowship (award no. NA11NOS4200090). The statements, findings, conclusions, and recommendations are those of the author and do not necessarily reflect the views of the

U.S. Forest Service, the U.S. Agriculture Department, The Nature Conservancy, NOAA, or the Department of Commerce. 


\section{REFERENCES}

Adame, M.F., Zaldívar-Jimenez, A., Teutli, C., Caamal, J.P., Andueza, M.T., LópezAdame, H., Cano, R., Hernández-Arana, H.A., Torres-Lara, R., Herrera-Silveira, J.A., 2013. Drivers of mangrove litterfall within a karstic region affected by frequent hurricanes. Biotropica, 45:147-154.

Aké-Castillo, J.A., Vázquez, G. Lopez-Portillo, J., 2006. Litterfall and decomposition of Rhizophora mangle L. in a coastal lagoon in the southern Gulf of Mexico. Hydrobiologia, 559: 101-111.

Alongi, D. M., 2009. The Energetics of Mangrove Forests. Springer, New York.

Arreola-Lizárraga, J.A., Flores-Verdugo, F.J. and Ortega-Rubio, A., 2004. Structure and litterfall of an arid mangrove stand on the Gulf of California, Mexico. Aquatic Botany, 79:137-143.

Boto, K. G. \& Wellington, J. T., 1983. Phosphorus and nitrogen nutritional status of a northern Australian mangrove forest. Marine Ecology Progress Series 11: 63-69.

Bouillon, S., 2011. Storage beneath mangroves. Nature Geoscience, 4: 282-283

Bouillon, S., Dahdouh-Guebas, F., Rao, A. V. V. S., Koedam, N., Dehairs, F., 2003;

Sources of organic carbon in mangrove sediments: variability and possible ecological implications. Hydrobiologia, 495: 33-39.

Bouillon, S., Connolly, R. M., Lee, S. Y., 2008. Organic matter exchange and cycling in mangrove ecosystems: Recent insights from stable isotope studies. Journal of Sea Research, 59: 44-58. 
Bowen, J. L., Valiela, I., 2008. Using $\delta^{15} \mathrm{~N}$ to assess coupling between watersheds and estuaries in temperate and tropical regions. Journal of Coastal Research, 24: 804813.

Capella, J., 2008. Environmental setting. In: Field, R. (ed.) Jobos Bay Estuarine Profile. Revised June 2008 by Angel Dieppa. Jobos Bay National Estuarine Research Reserve. https://coast.noaa.gov/data/docs/nerrs/Reserves_JOB_SiteProfile.pdf. Last accessed December, 2015.

Clough, B.F., Dixon, P., Dalhaus, O., 1997. Allometric relationships for estimating biomass in multi-stemmed mangrove trees. Australian Journal of Botany, 45: 1023-1031.

Corredor, J. E., Howarth, R. W., Twilley, R. R., Morell, J. M., 1999. Nitrogen cycling and anthropogenic impact in the tropical interamerican seas. Biogeochemistry, 46: 163-178.

Darby, F.A. Turner, R. E., 2008. Below- and aboveground biomass of Spartina alterniflora: response to nutrient addition in a Louisiana salt marsh. Estuaries and Coasts, 31: 326-334

Day, J.W., Conner, W.H., Ley-Lou, F., Day, R.H., Navarro, A.M., 1987. The productivity and composition of mangrove forests, Laguna de Terminos, Mexico. Aquatic Botany, 27, 267-284.

Day, J.W., Coronado-Molina, C., Vera-Herrera, F.R., Twilley, R., Rivera-Monroy, V.H., Alvarez-Guillen, H., Day, R., Conner, W., 1996. A 7 year record of above-ground net primary production in a southeastern Mexican mangrove forest. Aquatic Botany, 55: 39-60. 
Deegan, L.A., Bowen, J.L., Drake, D., Fleeger, J.W., Friedrichs, C.T., Galvan, K.A., Hobbie, J.E., Hopkinson, C., Johnson, D.S., Johnson, J.M., LeMay, L.E., 2007. Susceptibility of salt marshes to nutrient enrichment and predator removal. Ecological Applications, 17, S42-S63.

Deegan, L. A., Johnson, D. S., Warren, R. S., Peterson, B. J., Fleeger, J. W., Fagherazzi, S., Wollheim, W. M., 2012. Coastal eutrophication as a driver of salt marsh loss. Nature, 490: 388-392.

Donato, D. C., Kauffman, J. B., Murdiyarso, D., Kurnianto, S., Stidham, M., Kanninen, M., 2011. Mangroves among the most carbon-rich forests in the tropics. Nature Geoscience, 4: 293-297.

Downing, J. A., McClain, M., Twilley, R., Melack, J. M., Elser, J., Rabalais, N. N., Lewis, W.M., Turner, R. E., Corredor, J., Soto, D., Yanez-Arancibia, A., Kopaska, J. A., Howarth, R. W., 1999. The impact of accelerating land-use change on the $\mathrm{N}$-cycle of tropical aquatic ecosystems: Current conditions and projected changes. Biogeochemistry, 46: 109-148.

Ewel, J. J., Whitmore, J. L., 1973. The Ecological Life Zones of Puerto Rico and the U. S. Virgin Islands. Forest Service Research Paper ITF-18.

Feller, I. C., 1995. Effects of nutrient enrichment on growth and herbivory of dwarf red mangrove (Rhizophora mangle). Ecological Monographs, 65: 477-505.

Feller, I. C., Whigham, D. F., McKee, K. L., Lovelock, C. E., 2003. Nitrogen limitation of growth and nutrient dynamics in a disturbed mangrove forest, Indian River Lagoon, Florida. Oecologia, 134: 405-414. 
Field, R. M., 2008. Introduction and Summary. In: Field, R. (ed.) Jobos Bay Estuarine Profile. Revised June 2008 by Angel Dieppa. Jobos Bay National Estuarine Research

Reserve. https://coast.noaa.gov/data/docs/nerrs/Reserves_JOB_SiteProfile.pdf. Last accessed December, 2015.

Hopkinson, C. S., Day, J. W., 1980. Modeling the relationship between development and storm water and nutrient runoff. Environmental Management, 4: 315-324.

Howarth, R.W., Billen, G., Swaney, D., Townsend, A., Jaworski, N., Lajtha, K., Downing, J.A., Elmgren, R., Caraco, N., Jordan, T., Berendse, F., 1996. Regional nitrogen budgets and riverine N \& P fluxes for the drainages to the North Atlantic Ocean: Natural and human influences. In: Howarth, R. W. (ed.) Nitrogen Cycling in the North Atlantic Ocean and its Watersheds (pp. 75-139). Springer Netherlands.

IFIA 2015. International Fertilizer Industry Association. http://ifadata.fertilizer.org/ucSearch.aspx Last accessed: September 2015.

Kauffman, J. B., Heider, C., Cole, T. G., Dwire, K. A., Donato, D. C., 2011. Ecosystem carbon stocks of Micronesian mangrove forests. Wetlands, 31: 343-352.

Komiyama, A., Ong, J. E., Poungparn, S., 2008. Allometry, biomass, and productivity of mangrove forests: A review. Aquatic Botany, 89: 128-137.

Kristensen, E., Bouillon, S., Dittmar, T., Marchand, C., 2008. Organic carbon dynamics in mangrove ecosystems: A review. Aquatic Botany, 89: 201-219. 
Lovelock, C.E., Feller, I.C., Ball, M.C., Engelbrecht, B.M., Ewe, M.L., 2006. Differences in plant function in phosphorus-and nitrogen-limited mangrove ecosystems. New Phytologist, 172, 514-522.

Lovelock, C. E., Ball, M. C., Martin, K. C., Feller, I., C., 2009. Nutrient enrichment increases mortality of mangroves. PLoS ONE 4, e5600. doi:10.1371/journal.pone.0005600.

Lugo, A. E., Snedaker, S. C., 1976. The ecology of mangroves. Annual Review of Ecology and Systematics, 39-64.

Martinuzzi, S., Gould, W. A., Lugo, A. E., Medina, E., 2009. Conversion and recovery of Puerto Rican mangroves: 200 years of change. Forest Ecology and Management, 257: 75-84.

NERRS, 2015. NOAA National Estuarine Research Reserve System (NERRS). Systemwide Monitoring Program. Data accessed from the NOAA NERRS Centralized Data Management Office website: http://www.nerrsdata.org/. Last accessed September, 2015.

Nixon, S.W. and Fulweiler, R. W., 2009. Nutrient pollution, eutrophication, and the degradation of coastal marine systems. In: Duarte, C.M. (ed). Global Loss of Coastal Habitats. Fundacion BBVA, Bilbao, Spain. 175 pp.

Onuf, C. P., Teal, J. M., Valiela, I.,1977. Interactions of nutrients, plant growth and herbivory in a mangrove ecosystem. Ecology, 58: 514-526.

Ortiz-Zayas, J. R., Cuevas, E., Mayol-Bracero, O. L., Donoso, L., Trebs, I., FigueroaNieves, D., McDowell, W. H., 2006. Urban influences on the nitrogen cycle in Puerto Rico. Biogeochemistry, 79: 109-133. 
Pendleton, L., Donato, D.C., Murray, B.C., Crooks, S., Jenkins, W.A., Sifleet, S., Craft, C., Fourqurean, J.W., Kauffman, J.B., Marbà, N. and Megonigal, P., 2012. Estimating global "blue carbon” emissions from conversion and degradation of vegetated coastal ecosystems. PloS one, 7, e43542. DOI:

10.1371/journal.pone.0043542

Pool, D. J., Lugo, A. E., Snedaker, S. C., 1975. Litter production in mangrove forests of southern Florida and Puerto Rico. In: Walsh, G. E., Snedaker, S. C., and Teas, H. J. (ed.) Proceedings of the International Symposium on Biology and Management of Mangroves. Institute of Food and Agricultural Sciences, University of Florida, Gainesville, Florida, USA. p. 213-237.

Rabalais, N.N., Nixon, S. W., eds. (2002). Dedicated Issue, Nutrient Over-enrichment in Coastal Waters: Global Patterns of Cause and Effect. Estuaries, 25.

Reef, R., Feller, I. C., Lovelock, C. E., 2010. Nutrition of mangroves. Tree Physiology, 30: $1148-1160$.

Schindler et al. 1971. Eutrophication of lake 227, experimental lakes area, northwestern Ontario, by addition of phosphate and nitrate. Journal of the Fisheries Research Board of Canada 28, 1763-1782.

Saenger, P. and Snedaker, S.C., 1993. Pantropical trends in mangrove above-ground biomass and annual litterfall. Oecologia, 96, 293-299.

Sherman, R. E., Fahey, T. J., Martinez, P., 2003. Spatial Patterns of Biomass and Aboveground Net Primary Productivity in a Mangrove Ecosystem in the Dominican Republic. Ecosystems, 6: 384-398. 
Short, F.T., 1987. Effects of sediment nutrients on seagrasses: literature review and mesocosm experiment. Aquatic Botany, 27: 41-57.

Smith, T. J., Whelan, K. R. T., 2006. Development of allometric relations for three mangrove species in South Florida for use in the Greater Everglades Ecosystem restoration. Wetlands Ecology and Management, 14: 409-419.

Steinke, T.D. and Ward, C.J., 1988. Litter production by mangroves. II. St Lucia and Richards Bay. South African Journal of Botany, 54: 445-454.

Tam N. F. Y., Wong, Y. S., Lan, C. Y., Wang, L. N., 1998. Litter production and decomposition in a subtropical mangrove swamp receiving wastewater. Journal of Experimental Marine Biology and Ecology, 226: 1-18.

Turner, R.E., Howes, B.L., Teal, J.M., Milan, C.S., Swenson, E.M., Goehringer-Toner, D.D., 2009. Salt marshes and eutrophication: An unsustainable outcome. Limnology and Oceanography, 54: $1634-1642$.

Twilley, R. R., Rivera-Monroy, V. H., 2005. Developing performance measures of mangrove wetlands using simulation models of hydrology, nutrient biogeochemistry, and community dynamics. Journal of Coastal Research, 40: 7993.

Twilley, R. R., Lugo, A. E., Patterson-Zucca, C., 1986. Litter production and turnover in basin mangrove forests in Southwest Florida. Ecology, 67: 670-683.

Twilley, R.R., Pozo, M., Garcia, V.H., Rivera-Monroy, V.H., Zambrano, R., Bodero, A., 1997. Litter dynamics in riverine mangrove forests in the Guayas River estuary, Ecuador. Oecologia, 111: 109-122.

Valiela, I. (2006). Global Coastal Change. Blackwell Publishing, Malden, MA. 368 p. 
Valiela, I., Teal, J. M., Persson, N. Y. (1976). Production and dynamics of experimentally enriched salt marsh vegetation: Belowground biomass. Limnology and Oceanography, 21: 245-252

Vandegehuchte, M. W., Guyot, A., Hubau, M., DeGroote, S. R. E., De Baerdemaeker, N. J. J., Hayes, M., Welti, N., Lovelock, C. E., Lockington, D. A., \& Steppe, K., 2014. Long-term versus daily stem diameter variation in co-occurring mangrove species: Environmental versus ecophysiological drivers. Agricultural and Forest Meterology, 192-193: 51-58.

Whigham, D. F., Verhoeven, J. T. A., Samarkin, V., Megonigal, P. J., 2009. Responses of Avicennia germinans (black mangrove) and the soil microbial community to nitrogen addition in a Hypersaline Wetland. Estuaries and Coasts, 32:926-936.

Woodroffe, C.D., 1982. Litter production and decomposition in the New Zealand mangrove, Avicennia marina var. resinifera. New Zealand Journal of Marine and Freshwater Research, 16: 179-188.

Woodroffe, C.D., Bardsley, K.N., Ward, P.J. and Hanley, J.R., 1988. Production of mangrove litter in a macrotidal embayment, Darwin Harbour, NT, Australia. Estuarine, coastal and shelf science, 26: 581-598.

Zitello, A. G., Whitall, D. R., Dieppa, A., Christensen, J. D., Monaco, M. E., Rohmann, S. O., 2008. Characterizing Jobos Bay, Puerto Rico: A watershed modeling analysis and monitoring plan. NOAA Technical Memorandum NOS NCCOS 76. $81 \mathrm{pp}$. 


\section{TABLES AND FIGURES}

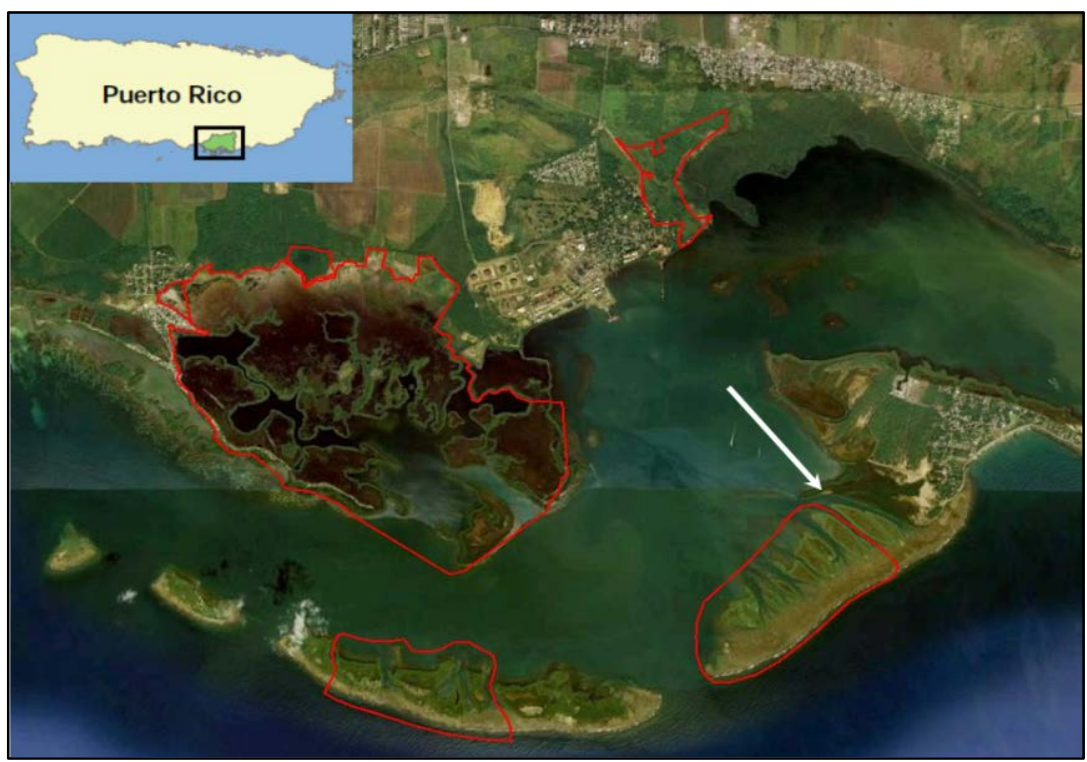

Figure 2-1. Satellite image of Jobos Bay, located in southeastern Puerto Rico. The boundaries of the Jobos Bay National Estuarine Research Reserve are outlined in red. A white arrow indicates the location of the nutrient enrichment experiment at offshore keys, approximately $3 \mathrm{~km}$ from the mainland (image credits: Zitello et al. 2008; NOAA-NERR 2015). 
Table 2-1. Stand characterization of the fringe mangrove site in this study measured at the start (October, 2011) and end (October, 2013) of the experiment. There was no change of stem density for mature trees. Three blocks were established within the stand, at least $100 \mathrm{~m}$ apart, for a complete randomized block design with three levels of nutrient treatment. Edaphic characterization of each block is presented in Chapter 1.

\begin{tabular}{|c|c|c|c|}
\hline \multirow[t]{2}{*}{ Block } & \multirow{2}{*}{$\begin{array}{c}\text { Stem density (count } \mathrm{m}^{-2} \text { ) } \\
\text { 2011-2013 } \\
\end{array}$} & \multicolumn{2}{|c|}{ Basal area $\left(\mathrm{m}^{-2} \mathrm{~m}^{-2}\right)$} \\
\hline & & 2011 & 2013 \\
\hline 1 & 1.1 & 31.6 & 32.7 \\
\hline 2 & 0.9 & 17.1 & 17.9 \\
\hline 3 & 1.2 & 19.7 & 23.0 \\
\hline
\end{tabular}


Table 2-2. Tree characterization (height, stem diameter at $1.3 \mathrm{~m}$, above-ground dry biomass) of the fringe mangrove site in this study measured at the start (October, 2011) and end (October, 2013) of the experiment. Above-ground biomass was calculated from species-specific allometric relationships based on stem diameter (Smith and Whelan 2006). There was no effect of nutrient treatment nor year on above-ground biomass values $(\mathrm{p}=0.5)$. No statistical test of tree height was performed.

\begin{tabular}{|c|c|c|c|c|c|c|c|}
\hline \multirow[t]{2}{*}{ Treatment } & \multirow[t]{2}{*}{ Block } & \multicolumn{2}{|c|}{ Tree height (m) } & \multicolumn{2}{|c|}{ Stem diameter $\left(\mathrm{cm}^{2}\right)$} & \multicolumn{2}{|c|}{ Biomass (kg DW m ${ }^{-2}$ ) } \\
\hline & & 2011 & 2013 & 2011 & 2013 & 2011 & 2013 \\
\hline \multirow[t]{3}{*}{ Control } & 1 & $4.8(0.3)$ & $5.1(0.4)$ & $6.1(0.6)$ & $6.2(0.6)$ & $14.7(3.6)$ & $15.4(3.5)$ \\
\hline & 2 & $5.4(0.5)$ & $5.1(0.3)$ & $4.7(0.5)$ & $4.8(0.6)$ & $6.6(1.6)$ & $7.0(1.7)$ \\
\hline & 3 & $3.3(0.5)$ & $3.1(0.6)$ & $3.5(0.7)$ & $3.7(0.7)$ & $5.2(3.4)$ & $5.9(3.7)$ \\
\hline \multirow[t]{3}{*}{ Agriculture } & 1 & $3.9(0.5)$ & $4.2(0.5)$ & $5.2(0.8)$ & $5.4(0.8)$ & $6.9(1.5)$ & $7.4(1.5)$ \\
\hline & 2 & $4.3(0.2)$ & $4.4(0.2)$ & $3.7(0.4)$ & $3.8(0.5)$ & $4.2(1.2)$ & $4.5(1.3)$ \\
\hline & 3 & $3.1(0.6)$ & $3.2(0.7)$ & $4.7(1.2)$ & $5.0(1.2)$ & $13.1(6.8)$ & $14.4(7.0)$ \\
\hline \multirow[t]{3}{*}{ Urban } & 1 & $5.1(0.9)$ & $5.0(1.0)$ & $5.2(0.6)$ & $5.4(0.7)$ & $8.3(1.8)$ & $9.8(2.1)$ \\
\hline & 2 & $5.5(0.4)$ & $4.7(0.3)$ & $5.1(0.6)$ & $5.3(0.6)$ & $8.3(2.1)$ & $9.1(2.4)$ \\
\hline & 3 & $3.6(0.6)$ & $3.8(0.6)$ & $3.4(0.6)$ & $3.7(0.6)$ & $3.9(6.9)$ & $4.8(4.5)$ \\
\hline
\end{tabular}




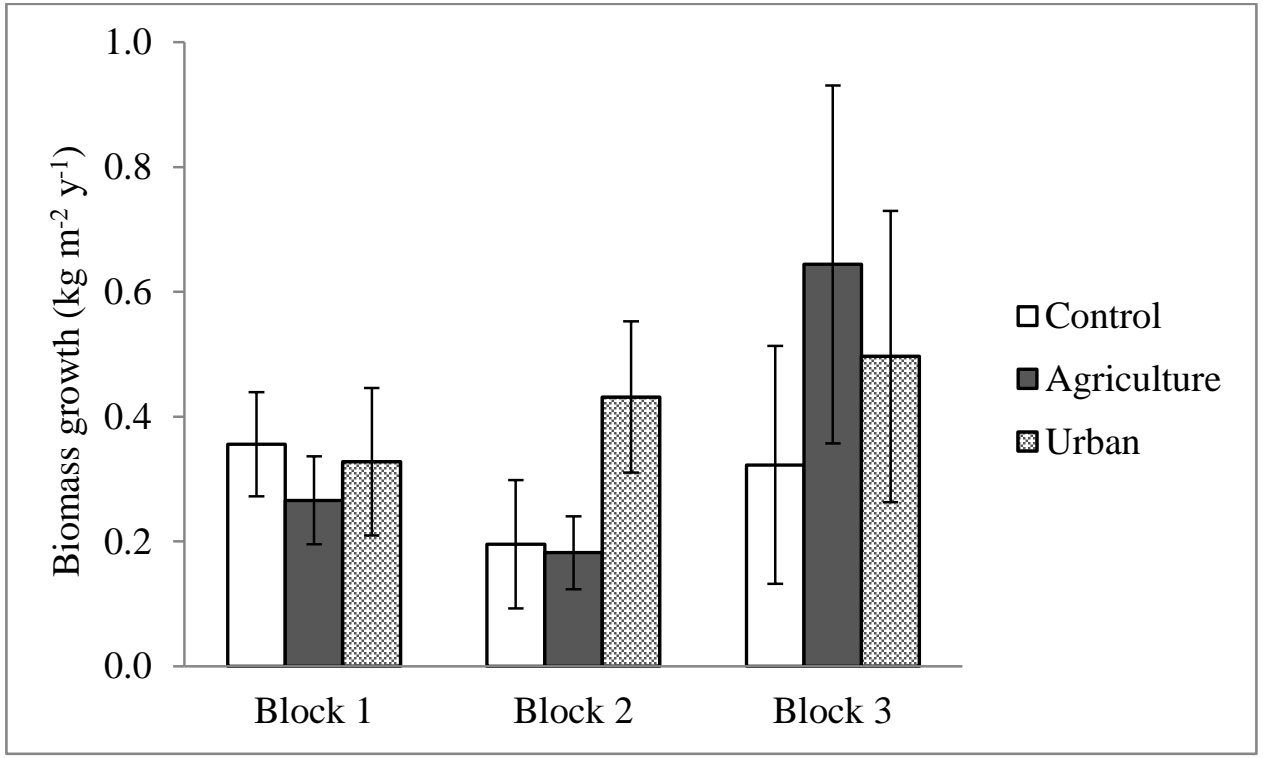

Figure 2-2. Above-ground mangrove production (wood and leaves; kg dry weight $\mathrm{m}^{-1}$ $\mathrm{y}^{-1}$ ) under three nutrient enrichment scenarios within three experimental blocks of a fringe forest. Production rate was calculated using an allometric equation for $R$. mangle or $L$. racemosa based on stem diameter at $1.3 \mathrm{~m}$ above the floor. There was no significant difference of biomass growth among nutrient treatment levels $(p=0.4)$. An assumption was made that the growth rate was constant during the two-year enrichment experiment (October 2011 to October 2013). Error bars are +/- 1 S.E. 


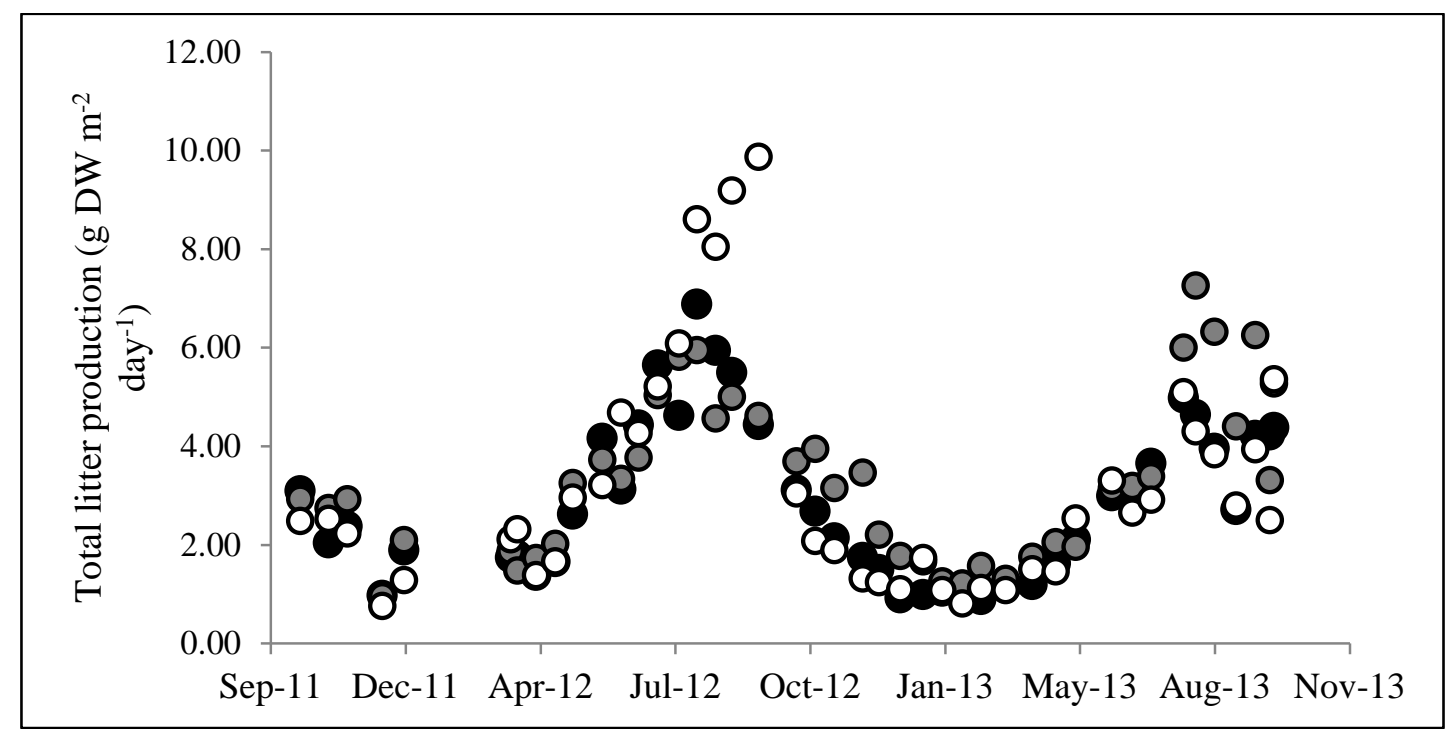

Figure 2-3. Total litter production in a fringe mangrove over two years of nutrient enrichment (Oct. 2011 to Oct. 2013) averaged across three blocks for three nutrient treatments: Control (closed black circles), Agriculture/high N:P (closed grey circles), Urban/intermediate N:P (open circles). 
$\mathbf{A}$
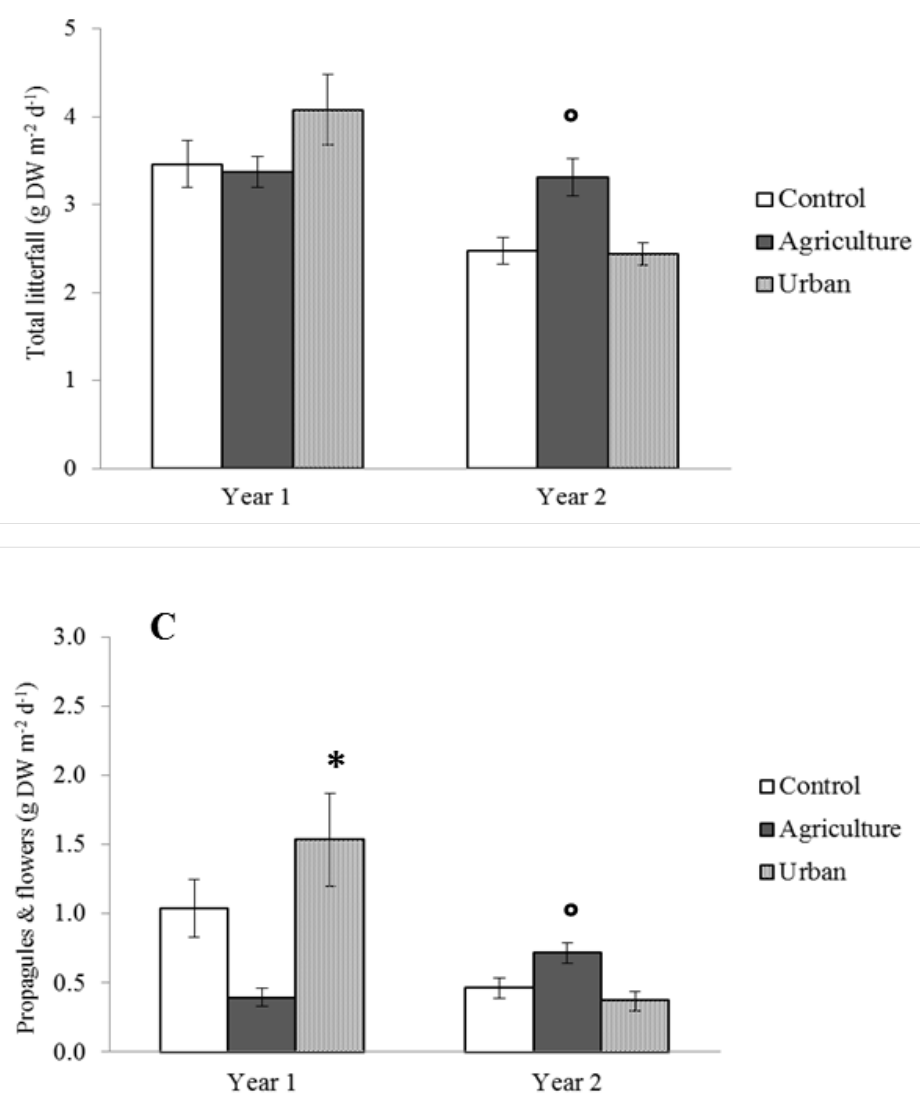
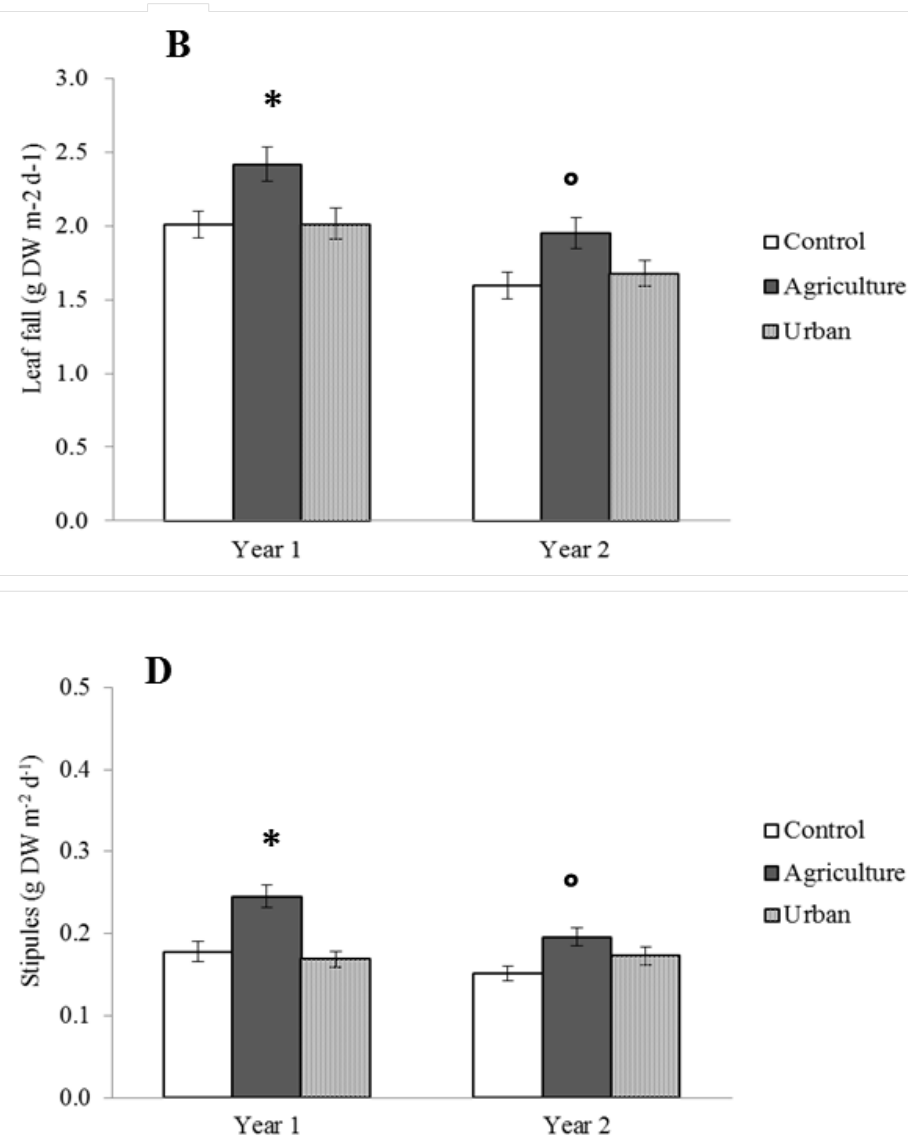

* Significant differences ( $\mathrm{p}<0.5)$; 。 Slight differences $(\mathrm{p} \leq 0.7)$

Figure 2-4. Total and component average litterfall (g dry weight m-2 day-1) by study year (year 1 = Oct. 2011 to Sept 2012 ; year 2 = Oct. 2011 to Sept. 2013). A = total litterfall; B = leaf fall; C = propagule and flower fall; $\mathrm{D}=$ stipule fall. Litterfall was collected every two weeks during the experimental period in duplicate $0.25 \mathrm{~m} 2$ baskets per unit (see Methods). Averages are across all 3 blocks by nutrient treatment. Note different $\mathrm{y}$-axis val* Significant differences $(\mathrm{p}<0.5)$; ${ }^{\circ}$ Slight differences $(\mathrm{p}<0.7)$ ues. Error bars are $+/-1 \mathrm{~S}$. E. 
Table 2-3. Results of two-factor repeated measures analyses of variance with blocking and interaction for total and component annual litterfall. Treatments are control (local channel water), agriculture (N:P ratio 50:1) and urban (N:P ratio 16:1). Litterfall was collected every-other week for two years in duplicate $0.25 \mathrm{~m}^{2}$ baskets per experimental unit (3 units within 3 blocks). Total and component litterfall values have been averaged over an experimental year (Oct. 2011 to Sept. 2012/Oct. 2012 to Sept. 2013). $n=36$.

\begin{tabular}{llrrrl}
\hline Litterfall component & Factor & Model $d f$ & Error $d f$ & \multicolumn{1}{l}{$F$} & $P$ \\
\hline Total litterfall & Treatment & 2 & 26 & 0.55 & 0.5836 \\
& Year & 1 & 2 & 0.69 & 0.4949 \\
& Treatment*year & 2 & 26 & 6.92 & $0.0039 * *$ \\
& & & & & \\
Leaves & Treatment & 2 & 26 & 3.57 & $0.0426^{*}$ \\
& Year & 1 & 2 & 1.68 & 0.3239 \\
& Treatment*year & 2 & 26 & 0.13 & 0.8747 \\
Stipules & & & & & \\
& Treatment & 2 & 26 & 4.16 & $0.0271^{*}$ \\
& Year & 1 & 2 & 0.11 & 0.7741 \\
& Treatment*year & 2 & 26 & 3.18 & $0.0581^{\circ}$ \\
& & & & & \\
Propagules \& flowers & Treatment & 2 & 26 & 0.32 & 0.7319 \\
& Year & 1 & 2 & 0.24 & 0.6748 \\
& Treatment*year & 2 & 26 & 7.85 & $0.0021^{* *}$ \\
\hline
\end{tabular}




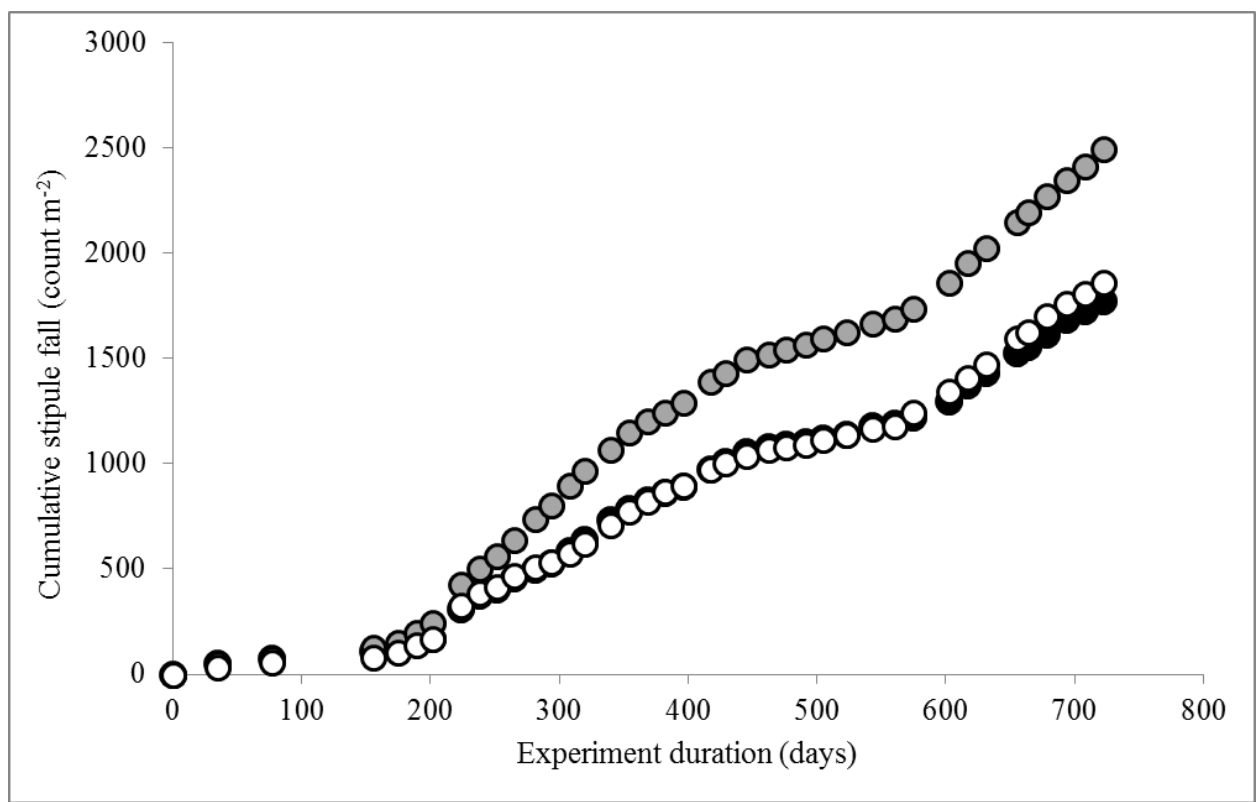

Figure 2-5. Cumulative stipule fall (count m-2) measured over two years of nutrient enrichment (Oct. 2011 to Oct. 2013) at three levels: Control (closed black circles), Agriculture/50:1 N:P (closed grey circles), Urban/16:1 N:P (open circles). Stipule fall was averaged across three blocks within the forest. The rate of stipule fall under agriculture treatment was significantly different than control $(p=0.00002)$ and urban $(p$ $=3.3 \mathrm{E}-05)$ treatments. No significant difference of stipule fall rate was found between urban and control treatments $(\mathrm{p}=1.0)$. 


\section{(A) Control}

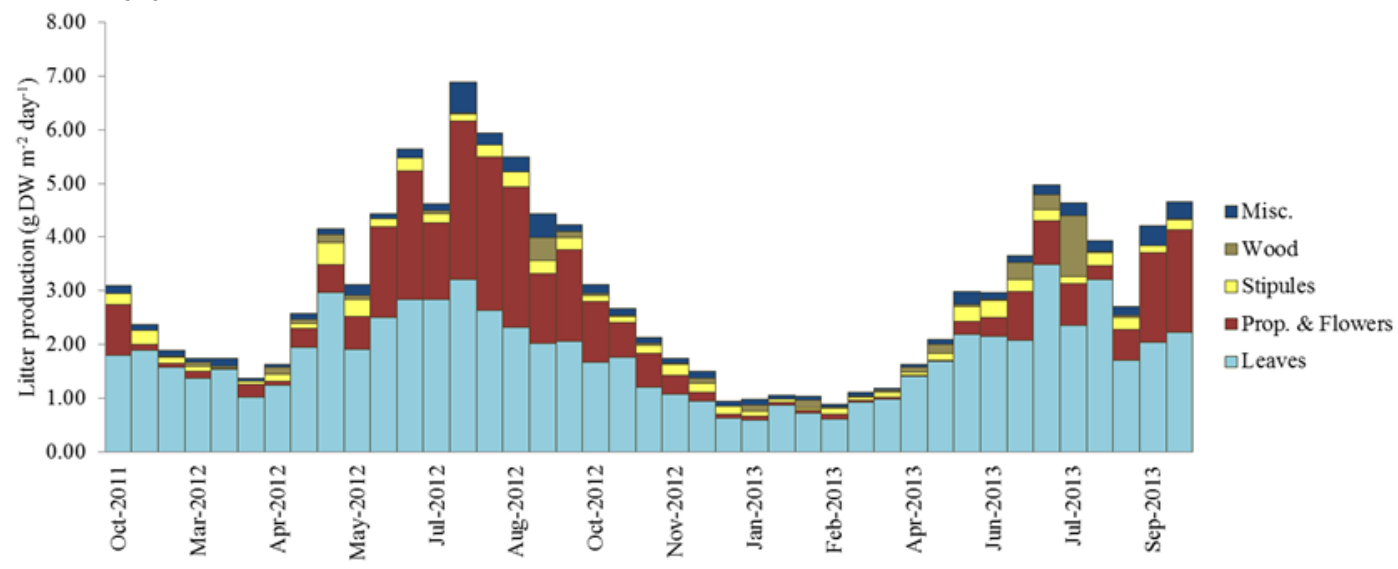

(B) Agriculture
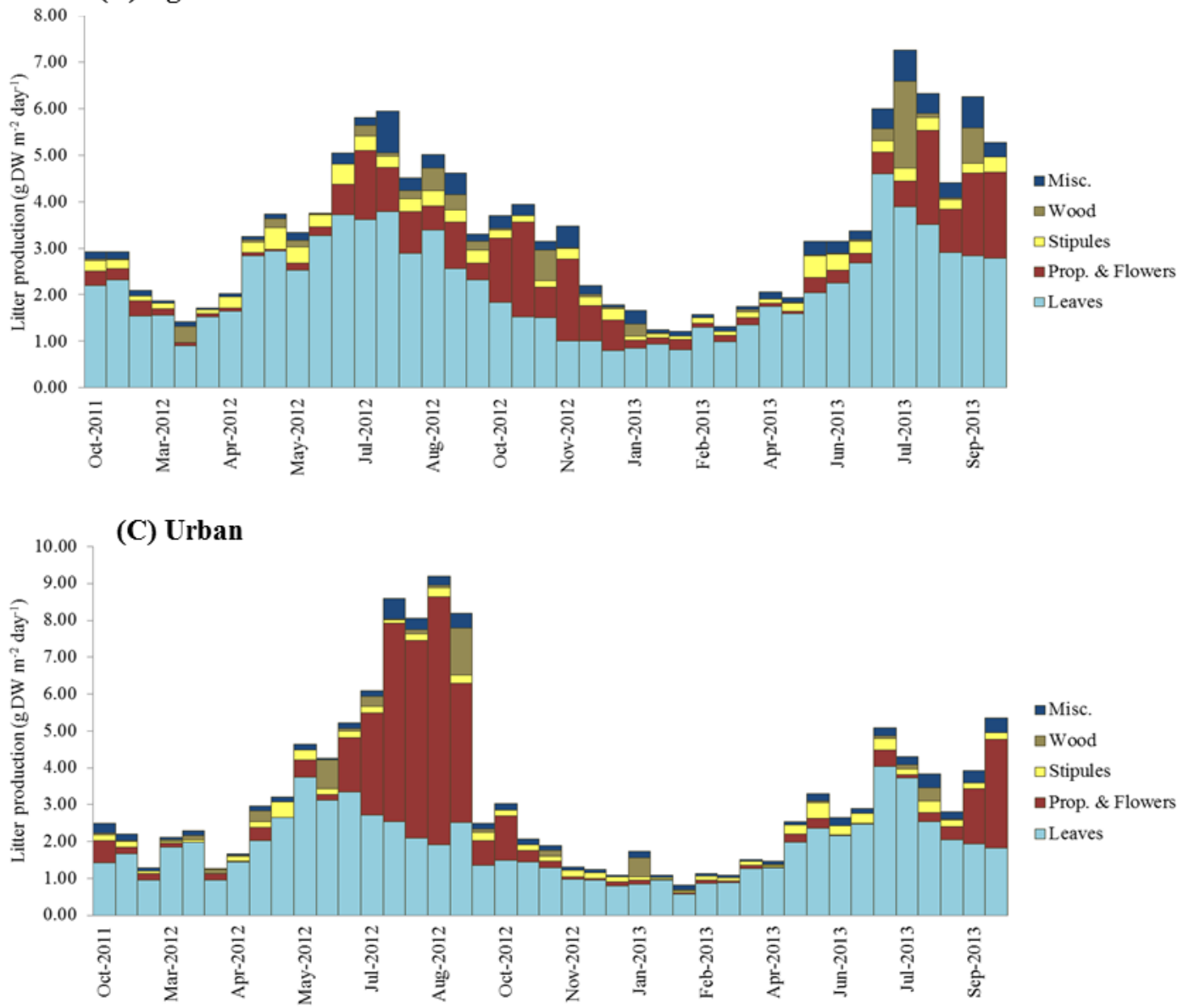

Figure 2-6. Litter production components over the two-year nutrient enrichment experiment (Oct. 2011 to Oct. 2013) averaged across three blocks for three nutrient treatments: (A) Control; (B) Agriculture/high N:P; (C) Urban/intermediate N:P. Litter components are: R. mangle and L. racemosa leaves (light blue); propagules and flowers (red); stipules (yellow); wood (tan); unidentified material (dark blue). Litter production was collected and measured every-other week. 
Table 2-4. Litter production rates (g dry mass $\mathrm{m}^{-2} \mathrm{y}^{-1}$ ) from studies conducted in Neotropical mangrove systems (Caribbean, Latin America, and northern South America). Forest type is based on Lugo and Snedaker (1974) classification.

\begin{tabular}{|c|c|c|c|c|}
\hline Location & Forest type & Species composition & Litter production (g DW m-2 y-1) & Reference \\
\hline Northeast Mexico & Dwarf & A. germinans & 175 & Arreola-Lizárraga et al. 2004 \\
\hline Southwest Florida & Basin & R. mangle, A. germinans, L. racemosa & 810 & Twilley et al. 1986 \\
\hline Southwest Florida & Basin & A. germinans & 444 & Twilley et al. 1986 \\
\hline Southwest Puerto Rico & Fringe & R. mangle & 480 & Golley et al. 1962 \\
\hline South Florida & Fringe & R. mangle, A. germinans, L. racemosa & 758 & Pool et al. 1975 \\
\hline Southeast Mexico & Fringe & R. mangle, L. racemosa & 835 & Day et al. 1987 \\
\hline Southeast Mexico & Fringe & R. mangle, A. germinans, L. racemosa & 1116 & Aké-Castillo et al. 2006 \\
\hline Southeast Puerto Rico & Fringe & R. mangle & 1690 & Lugo et al. 2007 \\
\hline Southeast Mexico & Fringe & R. mangle, A. germinans, L. racemosa & 880 & Adame et al. 2012 \\
\hline Southeast Puerto Rico & Fringe & R. mangle, L. racemosa & 1061 to 1217 & This study \\
\hline South Florida & Overwash & R. mangle, L. racemosa & 786 & Pool et al. 1975 \\
\hline South Florida & Riverine & R. mangle, A. germinans, L. racemosa & 818 to 918 & Pool et al. 1975 \\
\hline Southeast Mexico & Riverine & R. mangle, A. germinans, L. racemosa & 1252 & Day et al. 1987 \\
\hline Southern Ecuador & Riverine & Rhizophora spp. & 647 to 1064 & Twilley et al. 1997 \\
\hline
\end{tabular}


Table 2-5. Past field studies of experimental nutrient enrichment in mangroves. Mangrove responses to fertilizer input related to production (biomass change, litter production, photosynthesis rate, mortality rate) are briefly described.

\begin{tabular}{|c|c|c|c|c|c|c|c|c|c|}
\hline Location & Species/forest type & Nutrients applied & Fertilizer type & $\begin{array}{l}\text { Fertilization rate* } \\
\left(\mathrm{mol} \mathrm{m}^{-2} \mathrm{y}^{-1}\right)\end{array}$ & Duration & N-only & $\begin{array}{l}\text { Effects } \\
\text { P-only }\end{array}$ & $N \& P$ & Reference \\
\hline $\begin{array}{l}\text { Hitchinbrook Island, } \\
\text { Australia }\end{array}$ & $\begin{array}{l}\text { Rhizophoracae } \\
\text { family, } \\
\text { fringe/overwash }\end{array}$ & $\mathrm{NH}_{4} ; \mathrm{P}_{2} \mathrm{O}_{5}$ & $\begin{array}{l}\text { P buried (solid); } \\
\text { N subsurface } \\
\text { injection (liquid) }\end{array}$ & $0.7(\mathrm{~N}) ; 0.3(\mathrm{P})$ & 1 year & $\begin{array}{l}\text { Enhanced stipule } \\
\text { production (edge site) }\end{array}$ & $\begin{array}{l}\text { No effect at edge; } \\
\text { Enhanced stipule } \\
\text { production (interior } \\
\text { site) }\end{array}$ & -- & Boto and Wellington 1983 \\
\hline China & $\begin{array}{c}\text { Aegiceras } \\
\text { corniculatum; } \\
\text { Kandelia candel }\end{array}$ & $\begin{array}{l}\mathrm{N} \text { and } \mathrm{P} \text {; ionic } \\
\text { state unknown }\end{array}$ & Wastewater & $19.6(\mathrm{~N}) ; 0.9(\mathrm{P})$ & 2 years & -- & -- & $\begin{array}{l}\text { No effect on litter } \\
\text { production }\end{array}$ & Tam et al. 1998 \\
\hline Twin Cays, Belize & R. mangle, dwarf & $\begin{array}{l}\mathrm{NH}_{4} ; \mathrm{P}_{2} \mathrm{O}_{5} ; \\
\mathrm{N} \& \mathrm{P}\end{array}$ & Buried (solid) & $\begin{array}{c}15.0 \text { (N only); } \\
1.9 \text { (P only); } \\
3.3 \text { (N) \& } 0.6 \text { (P) }\end{array}$ & 2 years & No effect observed & $\begin{array}{l}\text { Greater tree height, } \\
\text { stem elongation, leaf } \\
\text { production; Lower leaf } \\
\text { sclerophylly }\end{array}$ & Same results as P-only & Feller 1995 \\
\hline $\begin{array}{l}\text { Indian River Lagoon, } \\
\text { Florida }\end{array}$ & $\begin{array}{l}\text { R. mangle, fringe; } \\
\text { A. germinans, } \\
\text { transition/dwarf }\end{array}$ & $\begin{array}{c}\mathrm{CH}_{4} \mathrm{~N}_{2} \mathrm{O} \\
\mathrm{P}_{2} \mathrm{O}_{5}\end{array}$ & Buried (solid) & $9.0(\mathrm{~N}) ; 1.9(\mathrm{P})$ & 2 years & $\begin{array}{l}\text { Greater leaf production } \\
\text { and stem elongation; } \\
\text { Enhanced } \\
\text { photosynthesis rate }\end{array}$ & No effect observed & -- & Feller et al. 2003 \\
\hline $\begin{array}{l}\text { Indian River Lagoon, } \\
\text { Florida }\end{array}$ & A. germinans, dwarf & $\mathrm{NO}_{3}$ & Monthly spray (liquid) & $0.7(\mathrm{~N})$ & 2 years & $\begin{array}{l}\text { Enhanced branching; } \\
\text { no effect on shoot } \\
\text { growth or leaf } \\
\text { production }\end{array}$ & -- & -- & Whigham et al. 2009 \\
\hline $\begin{array}{l}\text { Multiple sites within } \\
\text { Caribbean and Indo- } \\
\text { Pacific regions }\end{array}$ & Multiple, fringe/scrub & $\begin{array}{c}\mathrm{CH}_{4} \mathrm{~N}_{2} \mathrm{O} \\
\mathrm{P}_{2} \mathrm{O}_{5}\end{array}$ & Buried (solid) & $\begin{array}{c}9.0 \text { to } 15.0(\mathrm{~N}) \\
1.9(\mathrm{P})^{\dagger}\end{array}$ & 3 to 12 years & $\begin{array}{l}\text { Scrub: Increased } \\
\text { mortality under } \\
\text { drought conditions; } \\
\text { Fringe: no effect on } \\
\text { mortality }\end{array}$ & No effect on mortality & -- & Lovelock et al. 2009 \\
\hline $\begin{array}{l}\text { Jobos Bay, } \\
\text { Puerto Rico }\end{array}$ & Fringe & $\mathrm{NH}_{4} ; \mathrm{KH}_{2} \mathrm{PO}_{4}$ & 3i-weekly spray (liquid & $\begin{array}{l}5.0(\mathrm{~N}) \& 3.1(\mathrm{P}) \\
5.0(\mathrm{~N}) \& 9.7(\mathrm{P})\end{array}$ & 2 years & -- & -- & $\begin{array}{l}\text { Higher leaf and stipule } \\
\text { production (high N:P } \\
\text { only); no effect on } \\
\text { standing biomass }\end{array}$ & This study \\
\hline
\end{tabular}

*I assume buried fertilizer broadcast area is $1 \mathrm{~m}^{2}$

tUncertain from literature 


\title{
Chapter 3
}

\author{
NUTRIENT UPTAKE AND RETENTION WITHIN A FRINGE \\ MANGROVE STAND UNDER DIFFERENT NUTRIENT LOADS
}

To be submitted to the Journal of Experimental Marine Biology and Ecology

\begin{abstract}
Brita J. Jessen ${ }^{1}$, Candace Oviatt ${ }^{1}$, Arthur J. Gold ${ }^{2}$, Autumn J. Oczkowski $^{3}$, Richard McKinney ${ }^{3}$, Kenneth Miller ${ }^{4}$, Ryan Quinn ${ }^{2}$
\end{abstract}

1Graduate School of Oceanography; University of Rhode Island; 215 South Ferry Road; Narragansett, RI 02882 USA

${ }^{2}$ Dep. of Natural Resources Science; University of Rhode Island; One Greenhouse Road, Kingston, RI 02881

${ }^{3}$ U.S. EPA Atlantic Ecology Division; 27 Tarzwell Drive; Narragansett, RI 02882

${ }^{4}$ CSC, 6361 Walker Lane, Suite 300, Alexandria, VA 22310

${ }^{\dagger}$ Deceased 


\title{
NUTRIENT UPTAKE AND RETENTION WITHIN A FRINGE MANGROVE STAND UNDER DIFFERENT NUTRIENT LOADS
}

\begin{abstract}
A one-time spike of ${ }^{15} \mathrm{~N}$ stable isotope tracer was added to ambient (receiving local channel water) and chronically nutrient enriched (receiving $70 \mathrm{~g} \mathrm{~N} \mathrm{~m}^{-2} \mathrm{y}^{-1}$ and $9.7 \mathrm{~g} \mathrm{P} \mathrm{m}^{-}$ ${ }^{2} \mathrm{y}^{-1}$ for 21 to 24 months) sites within a coastal fringe mangrove forest in southeastern Puerto Rico to determine if nutrient enrichment was being retained in the mangrove ecosystem, and to identify mangrove $\mathrm{N}$ sinks. Measurements for ${ }^{15} \mathrm{~N}$ retention occurred at 1 month, 3 months, and 10 months after the initial spike. ${ }^{15} \mathrm{~N}$ tracer was recovered in all components (mangrove foliage, standing litter, surface sediment, and fine roots) within ambient and fertilized sites. The highest proportion of tracer retention (28 to 59\% under ambient conditions and 14 to $28 \%$ under nutrient enriched conditions) occurred in the organic layer of the forest floor (standing litter, surface sediment, and surficial fine roots). ${ }^{15} \mathrm{~N}$ retention within the mangrove canopy represented the smallest $\mathrm{N}$ sink, although foliar $\delta^{15} \mathrm{~N}$ continued to increase throughout the measurement period. Tracer retention within the organic layer of the forest floor indicates strong recycling and retention of nutrients that supports a highly-productive system in an oligotrophic marine environment. Chronically nutrient enriched sites retained more ${ }^{15} \mathrm{~N}$ tracer than ambient sites, but a smaller proportion of the applied ${ }^{15} \mathrm{~N}$ fertilizer, suggesting the capacity of nutrient retention had been exceeded by the added nutrient load.
\end{abstract}




\section{INTRODUCTION}

Coastal mangrove wetlands are encountering an unprecedented input of cultural nutrient enrichment to tropical coastlines (Corredor et al. 1999; Deegan et al. 2012), which may alter nutrient cycling and related functions within the mangrove stand and material exchange with other systems. Several studies have examined the effect of targeted nutrient addition (nitrogen, $\mathrm{N}$ and phosphorus, $\mathrm{P}$ ) on mangrove tree production and physiology (Feller et al. 1999, 2003, Whigham et al. 2009). Functional changes by mangroves under nutrient enrichment include higher production rates (Boto and Wellington 1983; Feller 1995; Chen and Twilley 1999), a decrease in the nutrient retranslocation efficiency (Feller et al. 2003) and a reduction of above-ground (shoot) to below-ground (root) biomass ratios (Naidoo 2009), which can increase mortality under drought conditions (Lovelock et al. 2009). However, other studies have found no strong link between nutrient enrichment and mangrove production (Whigham et al. 2009, Tam et al. 1998), which suggests these results depend upon environmental, floristic, and experimental design contexts.

Changes to mangrove production and nutrient use under chronic nutrient enrichment conditions has the potential to affect ecosystem services such as carbon (C) sequestration (Donato et al. 2011) and/or nutrient retention or exchange with adjacent marine systems (Rivera-Monroy and Twilley 1996; Valiela and Cole 2002). Nutrient enrichment may promote atmospheric $\mathrm{C}$ capture if the enhanced ecosystem component has a large C: $\mathrm{N}$ ratio, such as mangrove trees (C:N 200; Alongi 2009). Therefore a more clear understanding of the fate of nutrient enrichment will allow better prediction and management of mangroves as C sinks. Additionally, mangrove nutrient retention or 
exchange with adjacent marine systems may be influenced by chronic nutrient enrichment if the capacity to retain added nutrients has reached a threshold level (Verhoeven et al. 2006). The magnitude of this proposed threshold level (nutrient loading rates and duration), as well as influencing factors, are currently unknown.

In previous work (Chapters 1 and 2), I examined mangrove above-ground production and benthic $\mathrm{C}$ remineralization within a fringe mangrove system under experimental nutrient loading. At 18 months of fertilization, there was no observable effect on benthic $\mathrm{C}$ remineralization rates (sediment respiration and organic material decomposition), and a small increase of mangrove litter production under enriched conditions. These results encouraged the following questions concerning fate of the added $\mathrm{N}$ and implications for the $\mathrm{C}$ cycle:

1) For mangrove sites that have received chronic nutrient loading, are added nutrients continually taken up by the mangrove system? If so, what is the relative sink strength between main ecosystem components (mangrove foliage, standing litter, surface sediment, and fine roots)?

2) Does the amount of $\mathrm{N}$ addition affect the distribution of $\mathrm{N}$ retention into the ecosystem components?

3) Is there a threshold of $\mathrm{N}$ uptake capacity?

4) Will added $\mathrm{N}$ be retained within the system for months after enrichment?

In this work, I attempt to address these questions with the use of ${ }^{15} \mathrm{~N}$ stable isotope tracer, an effective tool to observe and quantify $\mathrm{N}$ movement and retention between main organic and inorganic pools of an ecosystem (Nadelhoffer et al. 1999; Drake et al. 2009). A one-time spike of ${ }^{15} \mathrm{~N}$-ammonium sulfate was applied to ambient and nutrient enriched 
fringe mangrove sites in southeastern Puerto Rico that had received pulsing aqueous nutrient enrichment or ambient channel water for 21 months prior to the ${ }^{15} \mathrm{~N}$ spike and continued for 3 more months. Main biomass pools (mangrove leaves, standing litter, top sediment, below-ground fine roots) were measured for ${ }^{15} \mathrm{~N}$ retention at repeated intervals (1, 3, 10 months) following ${ }^{15} \mathrm{~N}$ tracer addition to estimate nutrient enrichment uptake and retention within these ecosystem $\mathrm{N}$ pools.

\section{METHODS}

\section{Study site}

Jobos Bay is a coastal plain estuary located in southeastern Puerto Rico $\left(17^{\circ} 56^{\prime} \mathrm{N}\right.$, $\left.66^{\circ} 13^{\prime} \mathrm{W}\right)$. The mouth of the bay is mainly enclosed by mangrove-fringed limestone cays extending from a barrier coral reef. Caribbean surface seawater flows northward into the bay through channels between the cays. The local tidal cycle is mixed diurnal and ranges from 17 to $36 \mathrm{~cm}$, with the largest tides in October (Field 2008).

The location of this study is a fringe (sensu Lugo and Snedaker 1976) mangrove wetland positioned at the most southeastern channel of the bay, within the domain of the Aguirre State Forest. We selected this location as the least anthropogenically affected site within Jobos Bay, having the greatest distance from the bay-area residential, commercial, and agricultural land uses, and the mangrove-lined seawater channel flows from the low-nutrient Caribbean Sea to the bay. Additionally, stable isotope work by Bowen and Valiela (2008) has demonstrated that rooted vegetation at sites within Jobos Bay are disconnected from anthropogenic nitrogen sources. The coastal edge zone of the fringe mangrove forest (within 10-15 m upland of the coastline) is predominantly 
composed of red mangrove (Rhizophora mangle L.) with intermittent white mangrove (Laguncularia racemosa (L.) c.f. Gaertn.). The average canopy height is $4.24 \mathrm{~m}$ (range 0.76 to $7.09 \mathrm{~m}$ ) and the average diameter at breast height ( $1.3 \mathrm{~m}$ above the forest floor) is $5.26 \mathrm{~cm}$ (maximum $21.7 \mathrm{~cm}$ ). Greater detail of the experimental site forest structure is presented in Chapter 2.

\section{Chronic nutrient addition}

Three replicate blocks were established within the mangrove forest with at least 100 $\mathrm{m}$ spacing. The blocks were positioned parallel to the coastline and $5 \mathrm{~m}$ inland from the coastal edge. Each block contained three $4 \mathrm{~m}^{2}$ quadrats (“experimental units”) with at least $3 \mathrm{~m}$ of buffer space between the units. The experimental units were randomly assigned a nutrient treatment (ambient; high nitrogen/low phosphorus fertilization; high nitrogen/moderate phosphorus fertilization) which was applied every-other week for two years beginning October 2011. While the complete block is considered for biomass estimates (described below), for the purpose of this stable isotope study, only the ambient and high nitrogen/moderate phosphorus treatments will be considered (herein referred to as "ambient" and "fertilized," respectively). The treatments were applied by hand with a pressurized sprayer, with care taken to ensure that the spray was applied evenly within the quadrat and positioned close to the forest floor to limit volatilization. When possible, treatments were scheduled to coincide with low tides. Ambient treatment was $1 \mathrm{~L}$ of offshore channel water collected at the time of fertilization. Fertilized treatment was $1 \mathrm{~L}$ of locally-collected channel water with dissolved ammonium chloride and potassium phosphate (44.6 $\mathrm{g} \mathrm{NH}_{4} \mathrm{Cl}$ and $7 \mathrm{~g} \mathrm{KH}_{2} \mathrm{PO}_{4}$ per dose within the $4 \mathrm{~m}^{2}$ unit), for an annual fertilization of $70 \mathrm{~g} \mathrm{~N} \mathrm{~m}^{-2}$ and $9.7 \mathrm{~g} \mathrm{P} \mathrm{m}^{-2}$. 


\section{${ }^{15} \mathrm{~N}$ tracer addition}

In August 2013 (21 months after the start of the experiment) ${ }^{15} \mathrm{~N}$-ammonium sulfate (95.2\% isotope enrichment) was applied as a one-time spike divided over two concurrent days. The ${ }^{15} \mathrm{~N}$-enriched application followed the fertilization procedure described above, with designated hand sprayers to prevent subsequent isotopic contamination. For the fertilized sites, we applied the standard amount of $\mathrm{N}$ and $\mathrm{P}$ with $80 \%$ of the $\mathrm{N}$ in the form of $\left({ }^{15} \mathrm{NH}_{4}\right)_{2} \mathrm{SO}_{4}$ and $20 \%$ as un-enriched $\mathrm{NH}_{4} \mathrm{Cl}$. To calculate ${ }^{15} \mathrm{~N}$ input for ambient sites, we assumed a $15 \mathrm{~cm}$ water depth over the $4 \mathrm{~m}^{2}$ plot for a total of $600 \mathrm{~L}$ overflowing (tidal) water and increased the background level to $100 \mu \mathrm{M} \mathrm{N}$ in the form of $\left({ }^{15} \mathrm{NH}_{4}\right)_{2} \mathrm{SO}_{4}$. Our purpose of increasing the ambient $\mathrm{N}$ concentration above the background level (2 to $14 \mu \mathrm{M}$ channel water DIN) was to make certain that the ${ }^{15} \mathrm{~N}-\mathrm{NH}_{4}$ dominated the isotopic signal of new $\mathrm{N}$ input for this one-time addition. Our assumption is that the $\mathrm{N}$ spike did not significantly fertilize the ambient units to produce noticeable biochemical or physiological changes over the time period (weeks to months) of this

study. The total amount of $\mathrm{N}$ and $\mathrm{P}\left(\right.$ mols $\mathrm{m}^{-2}$ ) added to fertilized and ambient sites in early August 2013 is listed below.

\begin{tabular}{cccc} 
& \multicolumn{3}{c}{ Nutrient load $\left(\mathrm{g} \mathrm{m}^{-2}\right)$} \\
\cline { 2 - 4 } Fertilized & Total $\mathrm{N}$ & ${ }^{15} \mathrm{~N}$ & $\mathrm{P}$ \\
Ambient & 3.08 & 2.38 & 0.41 \\
& 0.45 & 0.43 & --
\end{tabular}

\section{Sampling}

Ecosystem component pools within the fringe mangrove system were separated into the following categories: living mature mangrove leaves; standing leaf litter forming the 
organic layer of the forest floor surface; surface sediment $(0$ to $2 \mathrm{~cm})$; fine to small below-ground roots and decomposed organic material at 0-15 cm depth. It was assumed that external organic C input was minimal in this micro-tidal, semi-arid system, and that these components represent much of the major organic C pools in this system, although above-ground woody biomass and large roots were not sampled.

\section{Foliage}

Each mangrove tree with at least one aerial root or set of pneumatophores located within an experimental unit was considered part of the experiment and assigned an ID. These trees were periodically measured for diameter at breast height (DBH; $1.3 \mathrm{~m}$ above the forest floor) and canopy height. The measurements were then used to determine above-ground biomass using allometric relationships (described below).

Leaf collection was performed just before ${ }^{15} \mathrm{~N}$ enrichment (July 2013), and at three intervals after ${ }^{15} \mathrm{~N}$ enrichment: late August 2013, mid-October 2013, and late May, 2014 (1, 2.5, and 6 months after the ${ }^{15} \mathrm{~N}$ enrichment event). All leaves were collected by hand in the lower part of the canopy; thus, only shade leaves were collected. Mature green leaves and senescent leaves still attached to the branch were collected and labeled with a permanent marker. Some experimental units did not contain trees with attached senescent leaves and some trees had leaves that were impossible to reach by climbing, particularly in block 2. When possible, 3 green or senescent leaves were collected for each tree. The collected leaves were stored in a dark cooler for transport from the field to the laboratory.

Leaves were rinsed with distilled water and air-dried overnight before weighing ("fresh weight"). Leaves were then dried at $45^{\circ} \mathrm{C}$ until a constant weight was reached 
(“dry weight”). Replicate leaves collected for the same tree were combined for elemental and isotopic analyses. To minimize confounding factors such as leaf size and age, midribs were removed from each leaf before analyses were conducted. The dried leaf tissue was ground using a Wiley-Mill with a \#20 sieve and stored at room temperature with a desiccant until laboratory analysis.

Leaves collected in July 2013 were immediately pressed and copied at 100\% aspect ratio. The images were uploaded to an image processing program (Image-J, v. 1.46, NIH Image, http://imagej.nih.gov/ij/), which was used to determine the surface area of each leaf without the petiole area. A hand-drawn $1 \mathrm{~cm}^{2}$ square was used to calibrate each measurement. Specific leaf area (area/dry weight) was calculated and averaged by block for biomass estimates.

\section{Standing litter}

The litter decomposition bag method (Karberg et al. 2008) was used to analyze $\mathrm{N}$ uptake and processing within the standing litter pool. Fiberglass mesh litter bags $\left(1 \mathrm{~mm}^{2}\right.$ pore size) containing locally-sourced newly fallen senescent leaves (5 per bag, approximately 3 g fresh weight) were deployed in July 2013 and collected periodically through a three-month period at 9, 32, 60, and 90 days. The litterbag method is described in greater detail in Chapter 1. Additional fallen leaves were collected within a $1 \mathrm{~m}$ perimeter of each block to obtain a fresh weight to dry weight conversion ratio for whole senescent leaves. The contents of the recovered litter bags were submerged in distilled water and carefully cleaned with a soft-bristled paintbrush to remove sediment. The contents were dried at $45^{\circ} \mathrm{C}$ until a constant weight was reached. The dry material was ground, stored, and analyzed by the same method as the collected mangrove leaves. 


\section{Sediment}

Surface sediment cores were collected for each experimental unit at the same time intervals as mangrove leaf collection (pre-enriched; $1,2.5$, and 6 months after the ${ }^{15} \mathrm{~N}$ enrichment event). Core locations were haphazardly selected with consideration to avoid benthic macro-algae cover, crab burrows, large surface roots or pneumatophores, or a location with a previous coring event. Any recent standing litter that had not become integrated with the sediment matrix was carefully removed before coring. Three $2.5 \mathrm{~cm}$ diameter replicate cores were collected from the top $2 \mathrm{~cm}$ of the sediment. The cores were segregated by depth $(0-1 \mathrm{~cm}, 1-2 \mathrm{~cm})$ and replicates within each unit were combined. The core sections were dried at $45^{\circ} \mathrm{C}$, ground with a mortar and pestle, and sieved through a $(200 \mu \mathrm{m})$ mesh to remove fine roots.

Using the same siting criteria, duplicate cores were collected with a commercial film canister $\left(4.6 \mathrm{~cm}\right.$ depth, $35.3 \mathrm{~cm}^{3}$ ). The cores were immediately weighed ("wet weight”) and then dried at $45^{\circ} \mathrm{C}$ until a constant weight was reached (“dry weight”). The ratio of dry weight to volume is the bulk density of the sediment and small root matrix. Roots were then sieved and the dry core was re-weighed for the bulk density of the sediment without the root volume.

\section{Below-ground fine roots}

For each experimental unit, one below-ground leaf litter bag $(5 \mathrm{~cm}$ x $10 \mathrm{~cm}, 3$ leaves per bag) that had incubated for 22 months was collected May 2014, 6 months after

the end of fertilization and 10 months after the ${ }^{15} \mathrm{~N}$ spike. The components of the belowground decomposition bag had fully integrated with ingrown roots. There were some 
small $(\leq 0.5 \mathrm{~cm})$ pieces of leaf material, but these were inseparable from the mat of fine roots. Thus these samples were considered below-ground fine root material.

\section{Biomass and $\mathbf{N}$ pool estimates}

The mass of ecosystem pool components (mangrove foliage, standing litter, sediment) was estimated by direct measurement, biometric-based allometry, or published literature values derived from a comparable mangrove system. For all components, the N pool was determined by elemental measurement of $\mathrm{N}$ (described below) and scaled to the ecosystem component mass.

Above-ground dry biomass was calculated using the following allometric relationship of dry biomass and DBH of $R$. mangle and L. racemosa provided in Smith and Wheland (2006):

$$
\log _{10} \mathrm{y}=\mathrm{a} \log _{10}(\mathrm{DBH})+\mathrm{b}
$$

where $\mathrm{y}=$ aboveground dry biomass in $\mathrm{kg}$ and $\mathrm{DBH}$ is in $\mathrm{cm}$

The following constants were used with the above equations (Smith and Whelan 2006):

\begin{tabular}{lcc}
\multicolumn{1}{c}{ Species } & Slope constant (a) & Interept constant (b) \\
\hline$R$. mangle & 1.731 & -0.112 \\
L. racemosa & 1.930 & -0.441
\end{tabular}

The calculated above-ground biomass was summed and divided by the total area of the experimental unit for an estimation of total stand biomass for each experimental block.

Mangrove leaf biomass was estimated from average DBH per experimental unit using equations in Smith and Whelan (2006). Leaf area and dry weight of at least 10 leaves per experimental unit were measured for a specific leaf weight $\left(\mathrm{g} / \mathrm{cm}^{2}\right)$. The 
specific leaf weight was used with the calculated canopy biomass for an estimate of total leaf area. The canopy leaf area was normalized by stem density (\# trees $\mathrm{m}^{-2}$ ) to obtain the leaf area index (LAI; leaf area $\left(\mathrm{m}^{2}\right) /$ plot area $\left.\left(\mathrm{m}^{2}\right)\right)$.

Standing litter on the forest floor was estimated from the average annual litter production measured by litter catch baskets (two $0.25 \mathrm{~m}^{2}$ per experimental unit, collected bi-weekly) and a turnover rate of $1.5 \mathrm{y}^{-1}$ reported for a Florida fringe mangrove system (Pool et al. 1975).

The sediment bulk density of each experimental unit was multiplied by $2 \mathrm{~cm}$ (the assumed depth of ${ }^{15} \mathrm{~N}$ tracer penetration) and scaled for a value of g DW $\mathrm{m}^{-2}$. Belowground fine root mass was estimated as $40 \%$ of the sediment bulk density (Corredor and Morell 1994).

\section{Elemental and $\delta^{15} \mathrm{~N}$ analysis}

Nomenclature and equations

Nitrogen isotopic composition was expressed using delta notation $\left(\delta^{15} \mathrm{~N}\right)$, which is parts per thousand $(\% 0)$ deviation from the ${ }^{15} \mathrm{~N}:{ }^{14} \mathrm{~N}$ molar ratio of the atmospheric standard $\left(\mathrm{R}_{\text {standard }}\right)$ as expressed in the following equation:

$$
\delta^{15} \mathrm{~N}=\left[\left(\mathrm{R}_{\text {sample }}-\mathrm{R}_{\text {standard }}\right) / \mathrm{R}_{\text {standard }}\right] \times 1000
$$

Where $\mathrm{R}$ is the molar ratio of ${ }^{15} \mathrm{~N}:{ }^{14} \mathrm{~N}$ and $\mathrm{R}_{\text {standard }}=0.0036765$.

For calculating percent retention (described below), $\delta^{15} \mathrm{~N}$ notation was converted to atom percent using the following equation (Fry 2006):

$$
\text { Atom percent (AP) of }{ }^{15} \mathrm{~N}=\left[100 *\left(\delta^{15} \mathrm{~N}+1000\right)\right] /\left[\delta^{15} \mathrm{~N}+1000+\left(1000 / \mathrm{R}_{\text {standard }}\right)\right]
$$

Laboratory analysis 
To determine isotopic composition and elemental content, approximately 5-7 mg of dry leaf sample or 12-15 mg of dry and sieved sediment sample were weighed into tin vials and measured with an Isoprime 100 Isotope Ratio Mass Spectrometer interfaced with a Micro Vario Elemental Analyzer (Elementar Americas, Mt. Laurel, NJ). The sample weights were recorded to the nearest microgram. The majority of the samples were run in duplicate to check for instrument precision. Only duplicate samples with $\leq$ $20 \%$ isotopic discrepancy were accepted and averaged for a final value.

Initial runs indicated a possible "carry-over effect" for samples with low $\delta^{15} \mathrm{~N}$ enrichment immediately following samples with a high $\delta^{15} \mathrm{~N}$ enrichment value. Samples that were identified as potentially affected by carry-over were re-run without highlyenriched $\delta^{15} \mathrm{~N}$ samples, and the lowest consistent $\delta^{15} \mathrm{~N}$ value was considered true. Subsequent runs were structured so that potentially low-enriched $\delta^{15} \mathrm{~N}$ samples were run first within a set, with increasing likelihood of $\delta^{15} \mathrm{~N}$ enrichment presenting later in the sample set. Samples with natural abundance ${ }^{15} \mathrm{~N}$ content (i.e., samples collected before ${ }^{15} \mathrm{~N}$ enrichment) were run in a separate group.

Laboratory standards were periodically used throughout each run (approximately every 24 samples) to identify potential instrument drift and to correct for measurement offset error. Elemental content (\%N or $\% \mathrm{C})$ was calculated by comparing the peak area of each unknown sample to a standard curve of peak area vs. known \%N content

\section{$\delta^{15} \mathrm{~N}$ mass balance}

${ }^{15} \mathrm{~N}$ tracer uptake within the ecosystem component pools was calculated from the $\mathrm{N}$ pool mass estimates and the difference in ${ }^{15} \mathrm{~N}$ concentration within each ecosystem 
components following the tracer addition, and was described as a proportion of the total ${ }^{15} \mathrm{~N}$ tracer applied for a retention value (Nadelhoffer et al. 1999):

$$
{ }^{15} \mathrm{~N}_{\text {recovered }}=\left[m_{\text {pool }}\left(\mathrm{AP}{ }^{15} \mathrm{~N}_{\text {pool }}-\mathrm{AP}{ }^{15} \mathrm{~N}_{\text {reference }}\right)\right] /\left(\mathrm{AP}{ }^{15} \mathrm{~N}_{\text {tracer }}-\mathrm{AP}{ }^{15} \mathrm{~N}_{\text {reference }}\right)
$$

where ${ }^{15} \mathrm{~N}_{\text {recovered }}$ is the mass of ${ }^{15} \mathrm{~N}$ tracer contained in the labeled $\mathrm{N}$ pool (g N m$\left.{ }^{-2}\right) ; m_{\text {pool }}$ is the total $\mathrm{N}$ mass of the component pool $\left(\mathrm{g} \mathrm{N} \mathrm{m}^{-2}\right)$; $A P{ }^{15} \mathrm{~N}_{\text {pool }}$ is the ${ }^{15} \mathrm{~N}$ atom percent of the labeled (enriched) component; $A P{ }^{15} \mathrm{~N}_{\text {reference }}$ is the natural abundance ${ }^{15} \mathrm{~N}$ atom percent of the component pool (sampled before labelling or from an adjacent unlabeled plot); AP ${ }^{15} \mathrm{~N}_{\text {tracer }}$ is the ${ }^{15} \mathrm{~N}$ atom percent of the ${ }^{15} \mathrm{~N}$-enriched fertilizer.

It was assumed that the ${ }^{15} \mathrm{~N}$ was processed through the $\mathrm{N}$ pools at the same rate as ${ }^{14} \mathrm{~N}$, and that fractionation effects, which are typically on the order of 2 to $3 \%$ (Fry and Cormier 2011), were negligible compared with the ${ }^{15} \mathrm{~N}$ tracer signal added. To estimate the percent of tracer recovery and its associated variability in each ecosystem component (green leaves, standing litter, fine roots and sediment), the following assumptions were made: (1) The mass of the $\mathrm{N}$ pools remained constant through the study period; (2) Reference (pre-labeled or non-labeled) ${ }^{15} \mathrm{~N}$ values do not change during the study period. Therefore any change in ${ }^{15} \mathrm{~N}$ values of sampled material after recovery is assumed to be a result of ${ }^{15} \mathrm{~N}$ tracer uptake.

Values of mangrove leaf $\delta^{15} \mathrm{~N}$ within reference pools that had been sampled in adjacent sites following ${ }^{15} \mathrm{~N}$ tracer addition ranged from 0.5 to $83 \%$, which presented a higher upper limit than was expected based on previous isotopic studies conducted in the mangroves of Jobos Bay. Demopolous et al. (2007) and Bowen and Valiela (2008) reported natural abundance ranges of 1 to 7 and -6 to $2 \%$, respectively. Based on these 
previous works, reference samples with d15N values higher than 20 \%o were considered contaminated by ${ }^{15} \mathrm{~N}$ tracer and were not included in the reference pool $\delta^{15} \mathrm{~N}$ value for tracer retention calculations.

\section{Statistical analyses}

A two-factor ANOVA with a blocking term was used to evaluate differences in $\mathrm{N}$ mass pools of each ecosystem component under ambient or enriched nutrient treatments. $\mathrm{C}: \mathrm{N}$ ratios of foliage, standing litter, and surface sediment were evaluated with a threefactor ANOVA with interaction term (treatment, time, treatment*time) and block effect. The same test was used for $\delta^{15} \mathrm{~N}$ analyses of each ecosystem component. To account for high variability, all $\delta^{15} \mathrm{~N}$ values were $\log _{10}$ transformed. Although other studies have arcsine transformed C:N ratios (e.g., Twilley et al. 1997), I did not alter the data as residuals were normally distributed. All tests included confirmation of variance homogeneity (Levene's test) and normality of the residuals (Shapiro-Wilk). A post-hoc Tukey’s test was performed for pair-wise analysis for variables that were significantly different from each other.

\section{RESULTS}

\section{Natural ${ }^{15} \mathrm{~N}$ abundances}

The upper limit of reference pool $\delta^{15} \mathrm{~N}$ values sampled from nearby (non- ${ }^{15} \mathrm{~N}$ enriched) sites following ${ }^{15} \mathrm{~N}$ tracer addition suggested tracer contamination (foliage, 0.5 to $146 \%$; litter, 2 to $127 \%$; sediment, 0 to 24\%o; Table $3-1$ ) . For tracer retention calculations, all reference samples with $\delta^{15} \mathrm{~N}$ values greater than $20 \%$ o were discarded. The discarded samples represented $18 \%$ of the total reference sample pool for foliage ( $n$ $=30), 50 \%$ of standing litter $(n=12)$, and $13 \%$ of the sediment samples $(n=8)$. The 
highest value of discarded $\delta^{15} \mathrm{~N}$ reference material represented less than $2 \%$ retention of ambient (low concentration) ${ }^{15} \mathrm{~N}$ tracer addition; thus the contamination effect was not strong. A 20\%o cut-off value is higher than natural $\delta^{15} \mathrm{~N}$ abundances reported for Jobos Bay vegetation (1 to $7 \%$, Demopoulos et al., 2007; -6 to $2 \%$, Bowen and Valiela, 2008) and has the potential to underestimate the amount of ${ }^{15} \mathrm{~N}$ tracer uptake by the labeled pools, but the majority of labeled component $\delta^{15} \mathrm{~N}$ values were orders of magnitude greater than this cut-off value.

In contrast, $\delta^{15} \mathrm{~N}$ of reference fine root samples collected before tracer addition ranged from -0.2 to $7 \%$.

\section{Ecosystem N pools}

A sum across components gives the total $\mathrm{N}$ pool range from 64 to $115 \mathrm{~g} \mathrm{~m}-2$ under ambient treatment and 60 to $108 \mathrm{~g} \mathrm{m-2}$ under enriched treatment (Tables 3-2 and 3-3). Fine roots constituted the greatest proportion of total $\mathrm{N}$ mass at 10 months after tracer addition (ambient: 41 to $74 \mathrm{~g} \mathrm{~m}$-2; enriched: 33 to $61 \mathrm{~g} \mathrm{~m}-2$ ), followed in descending order by surface sediment ambient: 12 to $23 \mathrm{~g} \mathrm{~m}-2$; enriched: 16 to $30 \mathrm{~g} \mathrm{~m}-2$, green leaves (ambient: 9 to $13 \mathrm{~g} \mathrm{~m}$-2; enriched: 9 to $12 \mathrm{~g} \mathrm{~m}$-2), and standing litter (ambient: 2 to $4 \mathrm{~g}$ m-2; enriched: 2 to $5 \mathrm{~g} \mathrm{~m}$-2). Nutrient enrichment treatment enhanced foliar $\mathrm{N}$ mass $(p=0.01)$, but did not affect standing litter nor sediment $\mathrm{N}$ mass $(\mathrm{p}=0.8$ and 0.2 , respectively).

Initial standing litter had the highest C:N content (ambient: 107 to 136; enriched: 112 to 128; Tables 3-2 and 3-3), which declined by 50 to $60 \%$ within three months of incubation on the forest floor, as time was a significant factor for litter C:N values $(\mathrm{p}<$ 0.001). Nutrient enrichment had a significant effect on foliar C:N values $(\mathrm{p}=0.05)$, and 
a small significant effect on standing litter $\mathrm{C}: \mathrm{N}(\mathrm{p}=0.07)$ but no significant effect on the $\mathrm{C}: \mathrm{N}$ values of surface sediment $(\mathrm{p}=0.2)$. Of the components measured, $\mathrm{C}: \mathrm{N}$ values decreased along the following pattern: initial standing litter $<$ fine roots $<$ standing litter, three months < green foliage $<$ sediment. This pattern differs from component $\mathrm{N}$ pool size ranking (described above), demonstrating that total mass and C:N values present different proportions for the component $\mathrm{N}$ pool quantity.

\section{${ }^{15} \mathrm{~N}$ tracer retention}

${ }^{15} \mathrm{~N}$ tracer was recovered in all measured ecosystem components at each observation point (1, 3, and 10 months following tracer addition). There were large ranges of $\delta^{15} \mathrm{~N}$ values for all components (Tables 3-2 and 3-3), with foliar values spanning three orders of magnitude. Standing leaf litter presented the highest $\delta^{15} \mathrm{~N}$ value under both ambient and nutrient enriched conditions by an order of magnitude above the other ecosystem components at early (1 month) measurements. Fine roots represented the next highest average $\delta^{15} \mathrm{~N}$ values, although the upper range of foliar $\delta^{15} \mathrm{~N}$ matched or exceeded these values. Nutrient conditions had a significant effect on sediment and mangrove foliage $\delta^{15} \mathrm{~N}$, but there was no nutrient effect on standing litter ${ }^{15} \mathrm{~N}$ (Table 3-4).

Mangrove foliage presented large $\delta^{15} \mathrm{~N}$ variation within experimental units (Tables 3-2 and 3-3) and between sampling time periods of individual trees (Figure 3-1). For individual trees, there was no clear pattern of $\delta^{15} \mathrm{~N}$ change with time following tracer addition; however, the majority of these trees exhibited higher $\delta^{15} \mathrm{~N}$ values 10 months after tracer addition compared with initial (1 month after tracer addition) samples. Time since tracer addition had a significant effect on foliar $\delta^{15} \mathrm{~N}$ (Table 3-4). The distribution of foliar $\delta^{15} \mathrm{~N}$ under ambient and enriched conditions shifted toward higher values during 
the 10-month observation period (Figure 3-2). For ambient treatment, the majority of foliar $\delta^{15} \mathrm{~N}$ values at 3 months after tracer addition was below 100\%, with a maximum range of 500\%. Under the same conditions at 10 months, the majority of foliar $\delta^{15} \mathrm{~N}$ values fell between 100 and 500\%, with one sample above 1000\%. Similarly, the distribution of foliar $\delta^{15} \mathrm{~N}$ values consistently shifted higher with time since tracer application in sites that had received chronic nutrient enrichment. All foliar $\delta^{15} \mathrm{~N}$ values were above $100 \%$ at 10 months after the tracer application, with the largest proportion of $\delta^{15} \mathrm{~N}$ values above $1000 \%$ at the enriched site.

This experiment applied different amounts of ${ }^{15} \mathrm{~N}$ tracer to ambient $\left(0.43 \mathrm{~g} \mathrm{~m}^{-2}\right)$ and nutrient enriched $\left(2.38 \mathrm{~g} \mathrm{~m}^{-2}\right)$ sites; therefore treatment-wise comparisons of absolute tracer retention as well as proportional retention is needed. Total ${ }^{15} \mathrm{~N}$ retention within nutrient enriched sites was 2 to 3 times greater than ${ }^{15} \mathrm{~N}$ retention under ambient conditions (Table 3-5). For all measurement periods, contribution of foliar ${ }^{15} \mathrm{~N}$ was greater for nutrient enriched sites (12 to $72 \mathrm{mg}{ }^{15} \mathrm{~N} \mathrm{~m}^{-2}$ ) compared with ambient sites (1 to $23 \mathrm{mg}{ }^{15} \mathrm{~N} \mathrm{~m}^{-2}$ ). For both treatments, the lowest foliar ${ }^{15} \mathrm{~N}$ retention relative to total ${ }^{15} \mathrm{~N}$ retention occurred 3 months after tracer addition. The highest foliar ${ }^{15} \mathrm{~N}$ contribution under ambient conditions (16 +/- $7 \mathrm{mg}$ mg ${ }^{15} \mathrm{~N} \mathrm{~m}^{-2}$ ) occurred 1 month after tracer addition, whereas the highest foliar ${ }^{15} \mathrm{~N}$ retention under enriched conditions (58.1 +/- $13.5 \mathrm{mg}^{15} \mathrm{~N} \mathrm{~m}^{-2}$ ) was measured 10 months after tracer addition. Average values of standing leaf litter accounted for 57 to $61 \%$ of total average ${ }^{15} \mathrm{~N}$ retention under ambient conditions and 49 to $61 \%$ of ${ }^{15} \mathrm{~N}$ retention under enriched conditions within 1 to 3 months after tracer addition. Factoring in fine root ${ }^{15} \mathrm{~N}$ retention at 10 months following tracer application (with the assumption that standing litter ${ }^{15} \mathrm{~N}$ retention was conserved), the 
organic layer of the forest floor (standing litter, top sediment, and surficial fine roots) accounted for $92 \%$ of ${ }^{15} \mathrm{~N}$ retention under ambient conditions and $77 \%$ of ${ }^{15} \mathrm{~N}$ retention under nutrient enriched conditions.

The proportional retention of applied ${ }^{15} \mathrm{~N}$ tracer was higher under ambient treatment (low tracer addition) compared with nutrient enrichment treatment (high tracer addition) for all ecosystem components across all sampling periods (Table 3-6; Figure 33). With the assumption that the fine root value is the same measured at 10 months after tracer addition, the sum of all component (foliage, standing litter, sediment, fine roots) proportional ${ }^{15} \mathrm{~N}$ retention was calculated to be 28 to 59\% (ambient) and 14 to 28\% (nutrient enriched) at 3 months after tracer addition. The fine roots component was equal to or greater than the sum of all other components. While a greater proportion of total tracer addition was retained by ambient sites, mangrove foliage ${ }^{15} \mathrm{~N}$ retention displayed a reverse pattern: foliar ${ }^{15} \mathrm{~N}$ uptake was greater under nutrient enrichment conditions $(0.7$ to $3 \%$ of high tracer addition) compared with ambient conditions ( 0.2 to $5 \%$ of low tracer addition).

\section{DISCUSSION}

The purpose of this study was to determine (1) if nutrient addition in a fringe mangrove forest was retained within some of the main ecosystem $\mathrm{N}$ pools (mangrove leaves, standing litter, sediment, and fine roots); (2) whether chronic enrichment affects the uptake capacity or distribution of additional nutrients within the system; (3) the fate of added $\mathrm{N}$ over a 10-month period following application. Following a one-time spike

\footnotetext{
,${ }^{15} \mathrm{~N}$ tracer was recovered within all measured ecosystem components of both chronically
} 
fertilized and ambient sites throughout the 10 month observation period. The locations and quantity of tracer recovery enables preliminary insight for the above questions.

\section{Mangrove $\mathbf{N}$ pools}

The largest pools of ${ }^{15} \mathrm{~N}$ retention were contained within the organic layer (measured as the upper $2 \mathrm{~cm}$ ) of the forest floor, which is a matrix of standing litter, sediment, and fine roots (Table 3-6 and Figure 3-3). Nutrient immobilization and re-use within the sediment matrix are considered to be important mechanisms of nutrient retention in the mangrove systems (Alongi 2009; Reef et al., 2010). Previous work has described rapid turnover (hours to days) of mineralized $\mathrm{N}$ within the mangrove sediment matrix, mainly due to high rates of ammonification and subsequent biological uptake of $\mathrm{NH}_{4}{ }^{+}$(Nedwell et al. 1994, Morell and Corredor 1993). Alongi et al. (1992) described efficient uptake of $\mathrm{N}$ solute at the soil-water interface as well as fast $\mathrm{N}$ turnover in the sediment in a north Queensland mangrove. They determined that the capacity to rapidly capture and recycle $\mathrm{N}$ inputs accounted for the high productivity of the mangroves, which would not be sustained by water-borne $\mathrm{N}$ input alone.

While foliar ${ }^{15} \mathrm{~N}$ retention was low compared with the sediment matrix, the proportion of foliar ${ }^{15} \mathrm{~N}$ retention increased during the observation period (1 to 10 months) in nutrient enriched plots (Figure 3-3B). This small but relatively greater importance of foliage as an $\mathrm{N}$ sink for nutrient enriched compared with ambient conditions may be explained by the lower $\mathrm{C}: \mathrm{N}$ ratio of leaves from nutrient enriched sites compared with ambient sites (Tables 3-2 and 3-3). Previous work has demonstrated that nutrient limitation relief in mangrove systems will decrease foliar nutrient use efficiency and nutrient reabsorption before leaf abscission (Feller et al. 2009, Reef et al. 2010). It 
may be more energetically favorable for mangrove trees to take up a greater quantity of $\mathrm{N}$ from the surrounding environment rather than reabsorb the nutrient before leaf senescence. Lastly, it is possible that the enhanced $\mathrm{N}$ availability reduced "competition" for nutrients between mangrove trees, the sediment microbial community, and sediment sorption of ionic $\mathrm{N}$.

As the purpose of this study was not focused on a complete $\mathrm{N}$ budget, there are significant unknown fates of the ${ }^{15} \mathrm{~N}$ tracer. Several $\mathrm{N}$ pools were not sampled, including above-ground roots and stems, coarse below-ground root material, and deeper (mineral) sediment cores. It is possible a significant portion of the "lost" ${ }^{15} \mathrm{~N}$ tracer could be recovered in these $\mathrm{N}$ sinks. A small contamination of nearby (at least $3 \mathrm{~m}$ away) "reference" sites suggests that some horizontal mixing of the surface layer occurs, although further work would be needed to determine if the exchange occurred naturally, or was enabled by our actions in the field. Other forms of $\mathrm{N}$ loss may include dissolved or particulate exchange via tidal flow, burial, denitrification, and $\mathrm{NH}_{4}{ }^{+}$volatilization (Alongi et al. 1992), which can vary according to the environmental conditions of a mangrove site (Alongi 2009).

\section{Effect of nutrient enrichment on $\mathrm{N}$ retention}

Chronically nutrient enriched treatment sites retained greater ${ }^{15} \mathrm{~N}$ tracer than ambient sites, but a lower proportion of the original ${ }^{15} \mathrm{~N}$ tracer amount (Tables 3-5 and 36). There does not appear to be a strong difference of $\mathrm{N}$ pools between the treatments (assuming that the unmeasured $\mathrm{N}$ pools were equally proportioned within ambient and enriched sites), so the lower proportional retention suggests a difference in uptake capacity or efficiency. One possibility is that first-order kinetics plays a factor, where the 
chance for encounter and uptake of the less concentrated ${ }^{15} \mathrm{~N}$ tracer before loss via tidal flushing or sorption to sediment particles was a constraint under ambient treatment. For nutrient enriched sites, lower proportional ${ }^{15} \mathrm{~N}$ tracer uptake but higher ${ }^{15} \mathrm{~N}$ retention values suggests that there was no encounter constraint and that ${ }^{15} \mathrm{~N}$ supply exceeded the system uptake capacity. This effect was also found by Drake et al. (2008) for a nutrient enriched salt marsh, with the conclusion that $\mathrm{N}$ loading exceeded uptake capacity by the marsh system.

The apparent threshold of $\mathrm{N}$ retention capacity by chronically nutrient enriched coastal wetlands may affect ecosystem service valuation and management. Mangroves and salt marshes have been suggested as sites of nutrient depuration and mitigation of eutrophic conditions that could otherwise promote negative effects for coral reefs and seagrass systems (e.g., Tam and Wong 1995; Corredor and Morell 1994; Valiela and Cole 2002). However, a "nutrient threshold" may define the potential of mangrove systems to effectively retain chronic nutrient input through hydrologic channels to the coastal marine ecosystem. This work demonstrates that the $\mathrm{N}$ retention threshold of a fringe mangrove is between 9.7 and $70 \mathrm{~g} \mathrm{~N} \mathrm{~m}^{-2} \mathrm{y}^{-1}$, but further work will be needed to refine this wide range.

The high recovery of ${ }^{15} \mathrm{~N}$ tracer within the fine root pool at 10 months past tracer application demonstrates long-term $\mathrm{N}$ recycling and storage mechanisms by the mangrove system. The long-term trend of ecosystem-scale turnover rates for recycled nutrients and final fate of added nutrients is still unknown. A periodic return to these sites for ${ }^{15} \mathrm{~N}$ sampling of the ecosystem components is highly recommended.

\section{$\mathrm{N}$ loading and the carbon cycle}


Greater retention of $\mathrm{N}$ within the mangrove system may enhance the ecosystem value as a $\mathrm{C}$ sink. $\mathrm{N}$ retention within sinks that have a high $\mathrm{C}: \mathrm{N}$ ratio would also conserve C. However, this study demonstrates the majority of mangrove $\mathrm{N}$ retention is dominated by the surface sediment components (standing litter, soil, and fine roots), which have a much lower $\mathrm{C}: \mathrm{N}$ value (30 to 100; Appendix) compared with mangrove tissue ( 200; Alongi 2009). Thus the capacity for mangrove $C$ sequestration would be greater if the mangrove trees were the major sinks of $\mathrm{N}$ rather than the surface sediment matrix. However, chronic nutrient enrichment has resulted in enhanced above-ground mangrove production (Chapter 2), and a long-term analysis of mangrove tree growth under enriched nutrient conditions is recommended.

\section{Variance and study design}

Tracer retention estimates were confounded by large variations of biomass estimates and $\delta^{15} \mathrm{~N}$ values for each $\mathrm{N}$ pool component within experimental units and between experimental blocks. High variability implicates the heterogeneity and spatial complexity within a stand dominated by red and white mangrove trees. The topography of the forest floor, determined in part by a tangle of above-ground roots, pneumatophores, and crab burrows, is likely an important factor in variations of sediment bulk density, standing litter turnover rates, and fine root growth.

For mangrove trees, large spatial distribution of above- and below-ground roots further complicates a field enrichment study. This study design was based on $4 \mathrm{~m}^{2}$ quadrats that do not fully encompass the spatial reach of each tree studied, and it was impossible to normalize for the proportion of each mangrove tree that encountered nutrient enrichment (especially if there were horizontal flow of added nutrients). This 
may account for some of the high variability of foliar $\delta^{15} \mathrm{~N}$. Ideally, a future stable isotope tracer in a mangrove setting would encompass wider study areas.

\section{CONCLUSION}

While chronic nutrient loading results in greater $\mathrm{N}$ uptake within some of the main ecosystem $\mathrm{N}$ pools (foliage, standing litter, sediment, fine roots), the proportional loss of ${ }^{15} \mathrm{~N}$ tracer compared with ambient treatment retention suggests that the capacity for $\mathrm{N}$ retention has been exceeded by this loading rate $\left(70 \mathrm{~g} \mathrm{~N} \mathrm{~m}^{-2} \mathrm{y}^{-1}\right)$. The recovery of ${ }^{15} \mathrm{~N}$ tracer within all ecosystem pools at 10 months following a one-time spike indicates efficient nutrient recycling between mangrove trees and the sediment matrix. A longterm (decadal) study of these sites may elucidate the longevity of added nutrient retention and cycling, and may be able to assess the terminal fate of added $\mathrm{N}$. 


\section{REFERENCES}

Alongi D.M., Boto K.G., \& Robertson A.I., 1992. Nitrogen and phosphorus cycles. In: Robertson A.I. \& Alongi D.M. (eds) Tropical mangrove ecosystems, American Geophysical Union, Washington, DC

Alongi, D., 2009. The energetics of mangrove forests. Springer Science \& Business Media.

Boto, K. G. \& J. T. Wellington, 1983. Phosphorus and nitrogen nutritional status of a northern Australian mangrove forest. Marine Ecology Progress Series 11: 63-69.

Bowen, J. L., \& Valiela, I., 2008. Using $\delta 15 \mathrm{~N}$ to assess coupling between watersheds and estuaries in temperate and tropical regions. Journal of Coastal Research 24: 804-813.

Chen, R., \& Twilley, R. R., 1999. Patterns of mangrove forest structure and soil nutrient dynamics along the Shark River estuary, Florida. Estuaries, 22: 955-970.

Corredor, J. E., \& Morell, J. M., 1994. Nitrate depuration of secondary sewage effluents in mangrove sediments. Estuaries, 17: 295-300.

Corredor, J. E., Howarth, R. W., Twilley, R. R., \& Morell, J. M., 1999. Nitrogen cycling and anthropogenic impact in the tropical interamerican seas. Biogeochemistry, 46: 163-178.

Deegan, L. A., Johnson, D. S., Warren, R. S., Peterson, B. J., Fleeger, J. W., Fagherazzi, S., \& Wollheim, W. M., 2012. Coastal eutrophication as a driver of salt marsh loss. Nature, 490: 388-392.

Donato, D. C., Kauffman, J. B., Murdiyarso, D., Kurnianto, S., Stidham, M., \& Kanninen, M., 2011. Mangroves among the most carbon-rich forests in the tropics. Nature Geoscience, 4: 293-297. 
Drake, D. C., Peterson, B. J., Deegan, L. A., Harris, L. A., Miller, E. E., \& Warren, R. S., 2008. Plant nitrogen dynamics in fertilized and natural New England salt marshes: a paired 15N tracer study. Marine Ecology Progress Series 354: 35-46.

Feller, I. C., 1995. Effects of nutrient enrichment on growth and herbivory of dwarf red mangrove (Rhizophora mangle). Ecological Monographs 65: 477-505.

Feller, I. C., Whigham, D. F., O'Neill, J. P., \& McKee, K. L., 1999. Effects of nutrient enrichment on within-stand cycling in a mangrove forest. Ecology, 80: 2193-2205.

Feller, I. C., McKee, K. L., Whigham, D. F., \& O'neill, J. P., 2003. Nitrogen vs. phosphorus limitation across an ecotonal gradient in a mangrove forest. Biogeochemistry, 62:145-175.

Field, R. M., 2008. Introduction and Summary. In: Field, R. (ed.) Jobos Bay Estuarine Profile. Revised June 2008 by Angel Dieppa. Jobos Bay National Estuarine Research

Reserve. https://coast.noaa.gov/data/docs/nerrs/Reserves_JOB_SiteProfile.pdf. Last accessed December, 2015.

Karberg, N. J., N. A. Scott, \& C. P. Giardina, 2008. Methods for estimating litter decomposition. In Hoover, C. M. (ed.) Field Measurements for Forest Carbon Monitoring, Springer, New York: 103-111.

Lovelock, C. E., Ball, M. C., Martin, K. C., Feller, I., C., 2009. Nutrient enrichment increases mortality of mangroves. PLoS ONE, 4 e5600. doi:10.1371/journal.pone.0005600.

Lugo, A. E., Snedaker, S. C., 1976. The ecology of mangroves. Annual Review of Ecology and Systematics, 39-64. 
Morell, J. M., \& Corredor, J. E., 1993. Sediment nitrogen trapping in a mangrove lagoon. Estuarine, Coastal and Shelf Science, 37: 203-212.

Naidoo, G. (2009). Differential effects of nitrogen and phosphorus enrichment on growth of dwarf Avicennia marina mangroves. Aquatic Botany, 90: 184-190.

Nadelhoffer, K. J., Downs, M. R., \& Fry, B., 1999. Sinks for 15N-enriched additions to an oak forest and a red pine plantation. Ecological Applications, 9: 72-86.

Nedwell, D. B., Blackburn, T.H., \& Wiebe, W.J., 1994. Dynamic nature of the turnover of organic carbon, nitrogen and sulphur in the sediments of a Jamaican mangrove forest. Marine Ecology Progress Series, 110: 223-231.

Pool, D. J., Lugo, A. E., Snedaker, S. C., 1975. Litter production in mangrove forests of southern Florida and Puerto Rico. In: Walsh, G. E., Snedaker, S. C., and Teas, H. J. (ed.) Proceedings of the International Symposium on Biology and Management of Mangroves. Institute of Food and Agricultural Sciences, University of Florida, Gainesville, Florida, USA. p. 213-237.

Reef, R., Feller, I. C., \& Lovelock, C. E., 2010. Nutrition of mangroves. Tree Physiology, 30: $1148-1160$.

Rivera-Monroy, V. H., \& Twilley, R. R., 1996. The relative role of denitrification and immobilization in the fate of inorganic nitrogen in mangrove sediments (Terminos Lagoon, Mexico). Limnology and Oceanography, 41: 284-296.

Smith, T. J., Whelan, K. R. T., 2006. Development of allometric relations for three mangrove species in South Florida for use in the Greater Everglades Ecosystem restoration. Wetlands Ecology and Management, 14: 409-419. 
Sprent, P., 1993. Applied Nonparametric Statistical Methods. Chapman \& Hall, London.

Tam, N. F. Y., \& Wong, Y. S., 1995. Mangrove soils as sinks for wastewater-borne pollutants. Hydrobiologia, 295: 231-241.

Tam, N. F. Y., Wong, Y. S., Lan, C. Y., \& Wang, L. N., 1998. Litter production and decomposition in a subtropical mangrove swamp receiving wastewater. Journal of Experimental Marine Biology and Ecology, 226: 1-18.

Valiela, I., \& Cole, M. L., 2002. Comparative evidence that salt marshes and mangroves may protect seagrass meadows from land-derived nitrogen loads. Ecosystems, 5: 92-102.

Verhoeven, J. T., Arheimer, B., Yin, C., \& Hefting, M. M., 2006. Regional and global concerns over wetlands and water quality. Trends in Ecology \& Evolution, 21: 96103.

Whigham, D. F., Verhoeven, J. T., Samarkin, V., \& Megonigal, P. J., 2009. Responses of Avicennia germinans (Black Mangrove) and the soil microbial community to nitrogen addition in a hypersaline wetland. Estuaries and Coasts, 32: 926-936. 


\section{TABLES AND FIGURES}

Table 3-1. Reference ${ }^{15} \mathrm{~N}$ abundances (means +/- 1 S.E.) in mangrove leaves, standing litter on the forest floor, surface sediment ( 0 to $2 \mathrm{~cm}$ ), and fine roots. Root samples were collected prior to the ${ }^{15} \mathrm{~N}$ tracer experiment; all other components were measured after the tracer addition, but in nearby plots that were not enriched with tracer. $\delta^{15} \mathrm{~N}$ values are expressed as deviation from the atmospheric standard $\left(0.3663\right.$ atom $\left.\%{ }^{15} \mathrm{~N}\right) . \delta^{15} \mathrm{~N}$ values greater than 20\%o were discarded (see Methods).

\begin{tabular}{lccc}
\hline Ecosystem pool & $\delta^{15} \mathrm{~N}(\%)$ & S.E. & $n$ \\
\hline Green leaves & 4.5 & 0.7 & 23 \\
Standing litter & 7.7 & 2.8 & 6 \\
Surface sediment $(0-2 \mathrm{~cm})$ & 11.5 & 3.0 & 4 \\
Fine roots & 0.5 & 0.3 & 7 \\
\hline
\end{tabular}


Table 3-2. Mass and $\mathrm{N}$ content of measured ecosystem components in fringe mangrove plots receiving ambient treatment $(1 \mathrm{~L}$ local channel water every-other week for 21 months), with one dose of $\left({ }^{15} \mathrm{NH}_{4}\right)_{2} \mathrm{SO}_{4}$ tracer $\left(0.057\right.$ moles $\left.{ }^{15} \mathrm{~N} \mathrm{~m}^{-2}\right)$ at the beginning of August, 2013. Low mass/fast turnover and high mass/slow turnover estimates were based on literature data (see Methods). Mass and $\mathrm{C}: \mathrm{N}$ values are means (+/-1 S.E.).

\begin{tabular}{|c|c|c|c|c|c|c|c|c|}
\hline & & & Ambier & at Treatment & & & & \\
\hline Component & $n$ & $\begin{array}{c}\text { Post tracer } \\
\text { (months) }\end{array}$ & Mass (kg DW m²) & Molar C:N & $\mathrm{N}$ mass $\left(\mathrm{g} \mathrm{m}^{-2}\right)$ & & $\delta^{15} \mathrm{~N}$ & \\
\hline & & & & & & $\min$ & $\max$ & mean \\
\hline Green leaves & 6 & 1 & $1.24(0.196)$ & $58.8(2.9)$ & 10.9 (1.9) & 7.2 & 1296 & 507 \\
\hline & 14 & 3 & $1.27(0.121)$ & 64.7 (3.4) & $10.4(1.3)$ & 3.7 & 394 & 55.1 \\
\hline & 8 & 10 & $1.27(0.171)$ & $56.5(1.3)$ & $11.0(1.5)$ & 18.4 & 1152 & 337 \\
\hline Standing litter & 3 & 1 week & $0.43(0.014)$ & 126.6 (9.8) & $1.8(0.2)$ & 1107 & 14156 & 6519 \\
\hline & 3 & 1 & $0.43(0.014)$ & $88.0(2.2)$ & $2.6(0.04)$ & 1021 & 11348 & 4918 \\
\hline & 3 & 3 & $0.43(0.014)$ & $64.1(5.5)$ & $3.9(0.1)$ & 1033 & 5794 & 4013 \\
\hline Sediment & 3 & 1 & $6.39(1.53)$ & $31.8(1.2)$ & $14.5(2.6)$ & 30.8 & 1246 & 520 \\
\hline & 3 & 3 & $5.59(1.23)$ & $30.5(0.8)$ & $22.1(1.2)$ & 81.2 & 1077 & 504 \\
\hline Fine roots & 3 & 10 & $8.53(2.67)$ & $74.1(3.4)$ & 57.7 (16.6) & 263 & 554 & 392 \\
\hline Range of total me & & & 11.7 to 21.0 & & 64 to 115 & & & \\
\hline
\end{tabular}


Table 3-3. Mass and N content of measured ecosystem components in fringe mangrove plots receiving nutrient enrichment treatment (1 L local channel water with 0.209 moles $\mathrm{NH}_{4} \mathrm{Cl}$ every-other week for 21 months), with one dose of $\left({ }^{15} \mathrm{NH}_{4}\right)_{2} \mathrm{SO}_{4}$ tracer $(0.159$ moles ${ }^{15} \mathrm{~N} \mathrm{~m}^{-2}$ ) at the beginning of August, 2013. Low mass/fast turnover and high mass/slow turnover estimates were based on literature data (see Methods). The $\delta^{15} \mathrm{~N}$ values hold for either mass estimate. Mass and C:N values are means (1 S.E.).

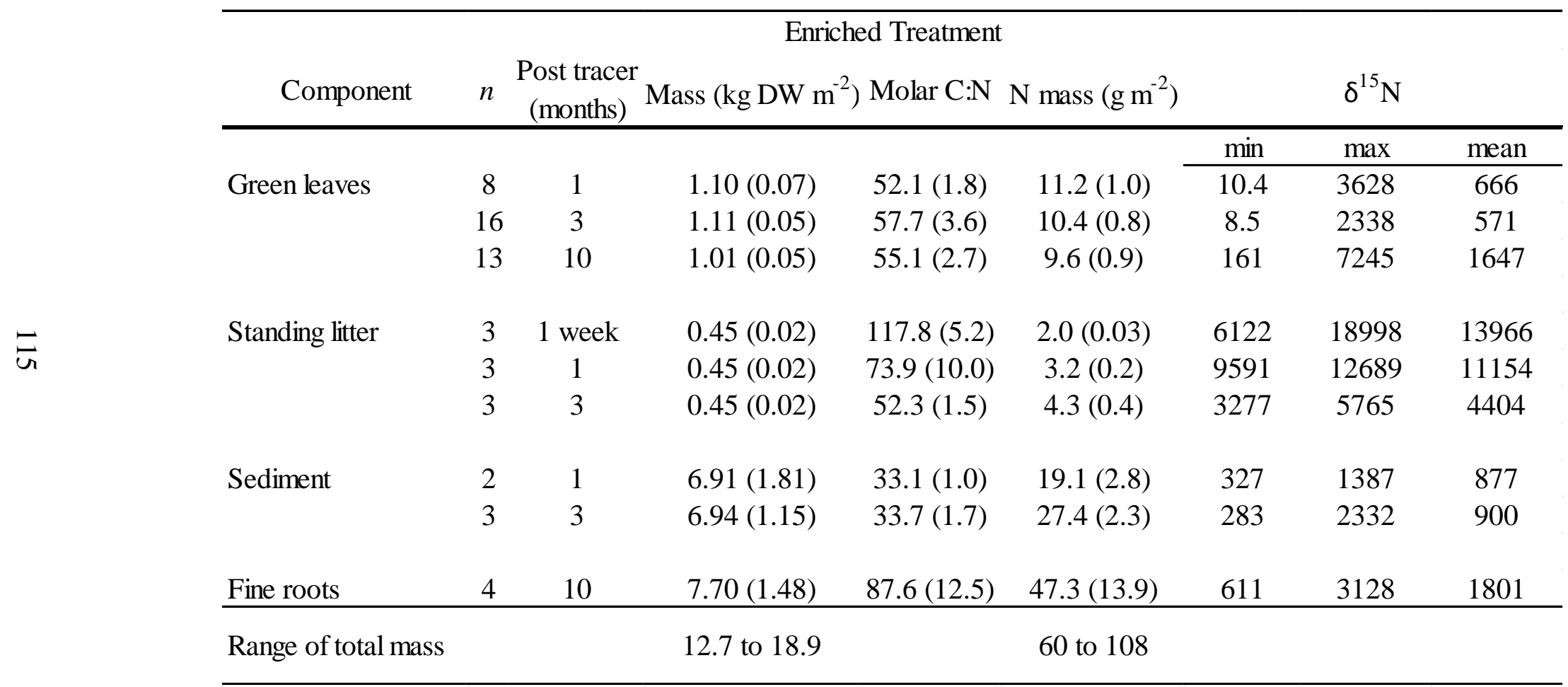


Table 3-4. Analysis of variance results for $\delta^{15} \mathrm{~N}$ values in measured main $\mathrm{N}$ pools of a fringe mangrove. Factors are nutrient treatment (ambient, fertilized) and time since ${ }^{15} \mathrm{~N}$ tracer was added (foliage and sediment: 1, 3, 10 months; standing litter: 1 week, 1 month, 3 months), with a randomized blocking effect. Fine roots were only sampled at 10 months following tracer addition. $\delta^{15} \mathrm{~N}$ were $\log _{10}$-transformed to account for high variability of $\delta^{15} \mathrm{~N}$ values.

\begin{tabular}{|c|c|c|c|c|c|c|c|}
\hline $\mathrm{N}$ pool component & Factor & $d f$ & & Sum Sq. & Mean Sq. & $F$ & $P$ \\
\hline \multirow[t]{3}{*}{ Foliage } & Treatment & & & 4.605 & 4.605 & 10.08 & $0.0024 * *$ \\
\hline & Time & & ? & 7.417 & 3.709 & 8.12 & $0.0008 * * *$ \\
\hline & Treatment*Time & & & 1.611 & 0.805 & 1.76 & 0.1808 \\
\hline \multirow[t]{3}{*}{ Standing litter } & Treatment & & 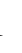 & 0.427 & 0.427 & 4.02 & 0.0680 \\
\hline & Time & & + & 0.517 & 0.129 & 1.22 & 0.3535 \\
\hline & Treatment*Time & & & 0.131 & 0.044 & 0.41 & 0.7478 \\
\hline \multirow[t]{3}{*}{ Sediment } & Treatment & & 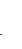 & 0.905 & 0.905 & 7.36 & $0.0134 *$ \\
\hline & Time & & ? & 0.031 & 0.016 & 0.13 & 0.8814 \\
\hline & Treatment*Time & & & 0.253 & 0.127 & 1.03 & 0.3756 \\
\hline Fine roots & Treatment & & 1 & 0.652 & 0.652 & 10.18 & $0.0242 *$ \\
\hline
\end{tabular}

* $P<0.05$; ** $P<0.01$; *** $P<0.001$ 


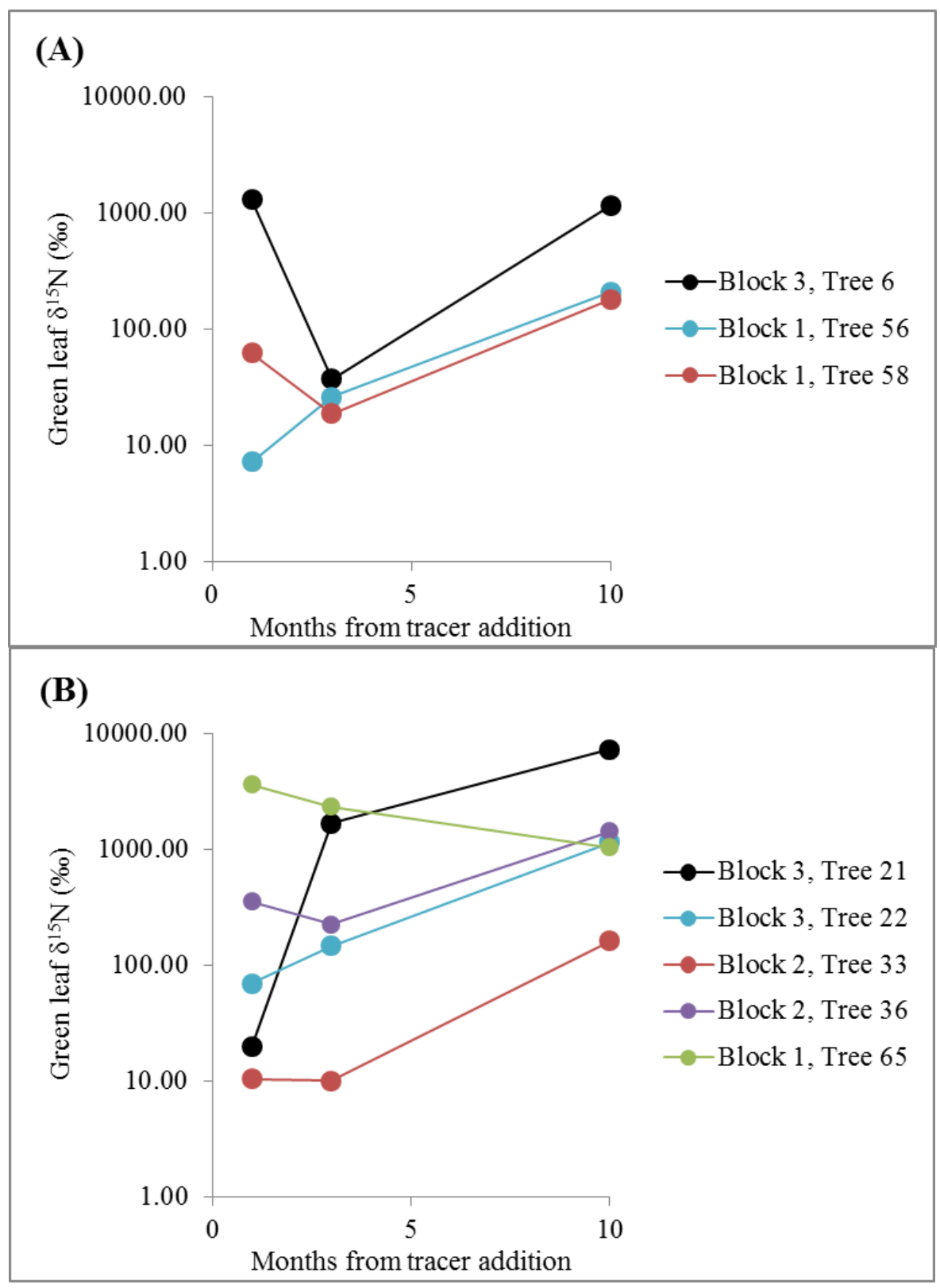

Figure 3-1. Values of $\delta^{15} \mathrm{~N}$ of individual tree foliage at three sampling intervals after ${ }^{15} \mathrm{~N}$ tracer was applied. (A) Ambient nutrient conditions, receiving $1 \mathrm{~L}$ channel water everyother week for 21 months before ${ }^{15} \mathrm{~N}$ tracer; (B) Chronically enriched nutrient conditions, receiving $1 \mathrm{~L}$ channel water with $\mathrm{NH} 4 \mathrm{Cl}$ fertilizer (loading rate $70 \mathrm{~g} \mathrm{~N} \mathrm{~m}^{-2}$ ) before ${ }^{15} \mathrm{~N}$ tracer. Individual trees were located within experimental blocks separated at least $100 \mathrm{~m}$ apart. Note log scale of y-axis. 

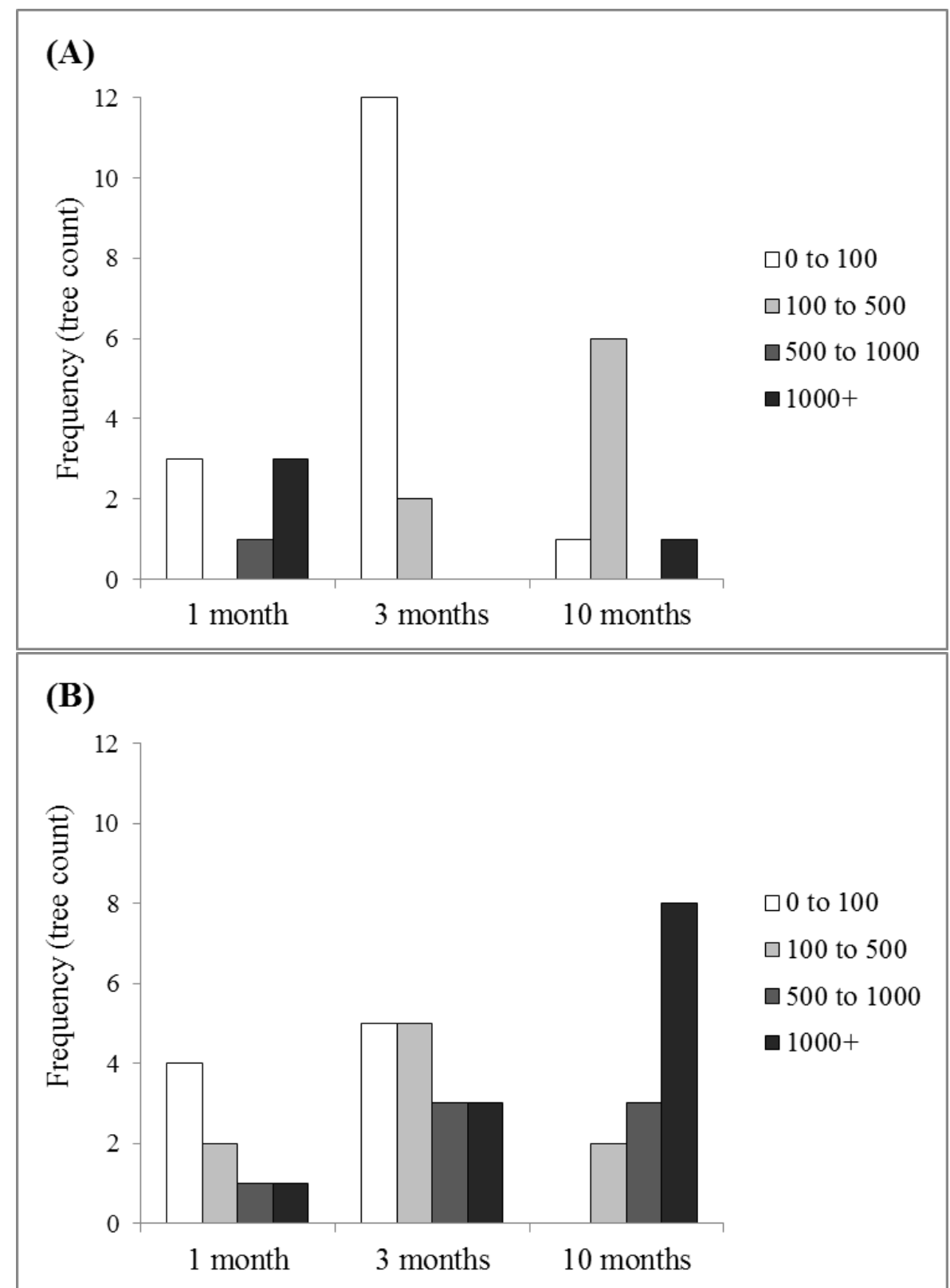

Figure 3-2. Frequency of $\delta^{15} \mathrm{~N}$ value categories from tree foliage at three sampling intervals after ${ }^{15} \mathrm{~N}$ tracer was applied. (A) Ambient nutrient conditions, receiving $1 \mathrm{~L}$ channel water every-other week for 21 months before ${ }^{15} \mathrm{~N}$ tracer; (B) Chronically enriched nutrient conditions, receiving $1 \mathrm{~L}$ channel water with $\mathrm{NH} 4 \mathrm{Cl}$ fertilizer (loading rate $70 \mathrm{~g} \mathrm{~N} \mathrm{~m}^{-2}$ ) before ${ }^{15} \mathrm{~N}$ tracer. Experimental blocks were combined by treatment. 
Table 3-5. ${ }^{15} \mathrm{~N}$ tracer retention $\left(\mathrm{mg} \mathrm{m}^{-2}\right.$ ) within measured ecosystem components in fringe mangrove plots receiving ambient treatment (1 L local channel water) or nutrient enrichment (1 L local channel water with 0.209 moles $\mathrm{NH}_{4} \mathrm{Cl}$ ) every-other week for 21 to 24 months, with one dose of $\left({ }^{15} \mathrm{NH}_{4}\right)_{2} \mathrm{SO}_{4}$ tracer (ambient: $0.43 \mathrm{~g}{ }^{15} \mathrm{~N} \mathrm{~m}^{-2}$; enriched: $2.38 \mathrm{~g}{ }^{15} \mathrm{~N} \mathrm{~m}^{-2}$ ) at the beginning of August, 2013. Nutrient enrichment ended October 2013. Recovery values are means (+/-1 S.E.). The sum of components for May 2014 (italicized) assumed standing litter and top sediment ${ }^{15} \mathrm{~N}$ recovery was equivalent to samples from October 2013.

\begin{tabular}{|c|c|c|c|c|c|c|}
\hline \multirow[b]{2}{*}{ Ecosystem component } & \multicolumn{2}{|c|}{ Aug. 2013} & $\begin{array}{r}\text { Oc } \\
3 \text { months } p\end{array}$ & $\begin{array}{l}013 \\
{ }^{5} \mathrm{~N} \text { addition }\end{array}$ & $\begin{array}{r}\text { May } \\
10 \text { months } p\end{array}$ & $\begin{array}{l}014 \\
{ }^{15} \mathrm{~N} \text { additon }\end{array}$ \\
\hline & Ambient & Enriched & Ambient & Enriched & Ambient & Enriched \\
\hline Green leaves & $16.0(6.7)$ & 39.4 (27.9) & $1.3(0.5)$ & $27.8(11.1)$ & $11.4(3.4)$ & $58.1(13.5)$ \\
\hline Standing litter & $46.7(30.1)$ & $151.4(12.6)$ & $59.5(22.5)$ & $80.2(13.6)$ & ND & ND \\
\hline Top sediment $(0-2 \mathrm{~cm})$ & $19.9(6.7)$ & 71.5 (27.2) & $38.5(9.1)$ & $102.0(35.5)$ & ND & ND \\
\hline Fine roots & ND & ND & ND & ND & $20.4(8.1)$ & $12.1(1.8)$ \\
\hline Sum of components & $82.6(43.5)$ & $262.3(67.7)$ & $99.3(32.1)$ & $210.0(60.2)$ & $129.8(43.1)$ & $252.4(64.4)$ \\
\hline
\end{tabular}


Table 3-6. Percent recovery of applied ${ }^{15} \mathrm{~N}$ within measured ecosystem components in fringe mangrove plots receiving ambient treatment (1 L local channel water) or nutrient enrichment (1 L local channel water with 0.209 moles $\mathrm{NH}_{4} \mathrm{Cl}$ ) every-other week for 21 to 24 months, with one dose of $\left({ }^{15} \mathrm{NH}_{4}\right)_{2} \mathrm{SO}_{4}$ tracer (ambient: $0.43 \mathrm{~g}^{15} \mathrm{~N} \mathrm{~m}^{-2}$; enriched: $2.38 \mathrm{~g}^{15} \mathrm{~N} \mathrm{~m}^{-2}$ ) at the beginning of August, 2013. Nutrient enrichment ended October 2013. Recovery values are means (+/-1 S.E.). The sum of components for May 2014 (italicized) assumed standing litter and top sediment ${ }^{15} \mathrm{~N}$ recovery was equivalent to samples from October 2013.

\begin{tabular}{|c|c|c|c|c|c|c|}
\hline \multirow[b]{2}{*}{ Ecosystem component } & \multicolumn{2}{|c|}{1 month post ${ }^{15} \mathrm{~N}$ addition } & \multicolumn{2}{|c|}{3 months post ${ }^{15} \mathrm{~N}$ addition } & \multicolumn{2}{|c|}{10 months post ${ }^{15} \mathrm{~N}$ additon } \\
\hline & Control & Fertilized & Control & Fertilized & Control & Fertilized \\
\hline Green leaves & $3.7(1.6)$ & $1.7(1.2)$ & $0.3(0.1)$ & $1.2(0.5)$ & $2.7(0.8)$ & $2.4(0.6)$ \\
\hline Standing litter & $10.9(7.0)$ & $6.4(0.5)$ & $13.8(5.2)$ & $3.4(0.5)$ & ND & ND \\
\hline Top sediment $(0-2 \mathrm{~cm})$ & $4.6(1.6)$ & $3.0(1.1)$ & $8.9(2.1)$ & $4.3(1.5)$ & ND & ND \\
\hline Fine roots & ND & ND & ND & ND & $20.4(8.1)$ & $12.1(1.8)$ \\
\hline Sum of components & $19.2(10.2)$ & $11.1(2.8)$ & $23.0(7.4)$ & $8.9(2.5)$ & $45.8(16.2)$ & $22.2(4.4)$ \\
\hline
\end{tabular}



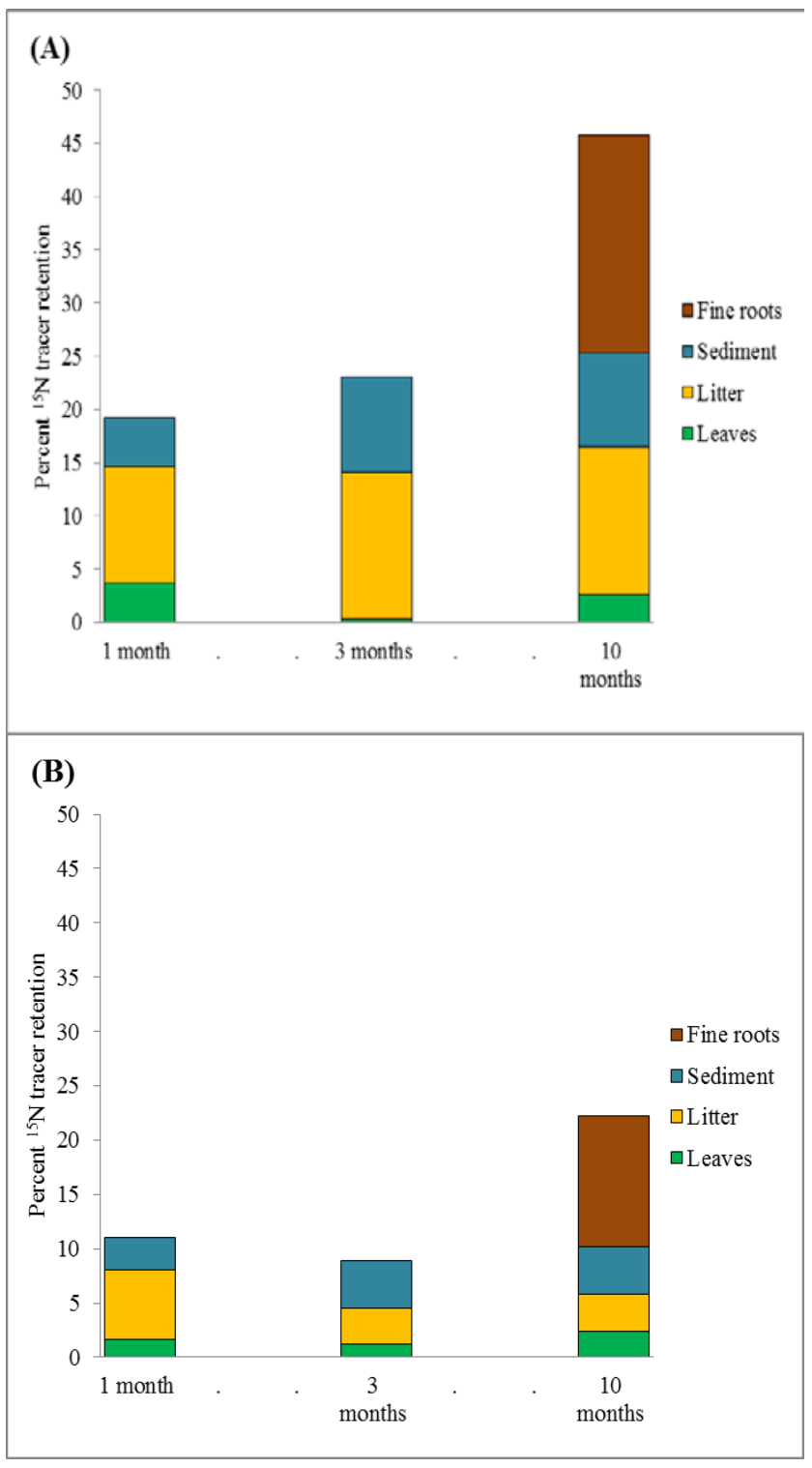

Figure 3-3. Percent ${ }^{15} \mathrm{~N}$ tracer retention at 1,3 , and 10 month time points after ${ }^{15} \mathrm{~N}$ tracer addition. (A) Ambient nutrient conditions, receiving $1 \mathrm{~L}$ channel water every-other week for 21 months before ${ }^{15} \mathrm{~N}$ tracer; (B) Chronically enriched nutrient conditions, receiving 1 $\mathrm{L}$ channel water with $\mathrm{NH}_{4} \mathrm{Cl}$ fertilizer (loading rate $70 \mathrm{~g} \mathrm{~N} \mathrm{~m}^{-2}$ ) before ${ }^{15} \mathrm{~N}$ tracer. Fine roots were only measured at 10 months following ${ }^{15} \mathrm{~N}$ tracer addition. Standing litter and top sediment were not measured at the 10 month sampling point; the values from the 3 month period was used for comparison among all components. 


\section{Appendix A: Supplemental tables and figures}

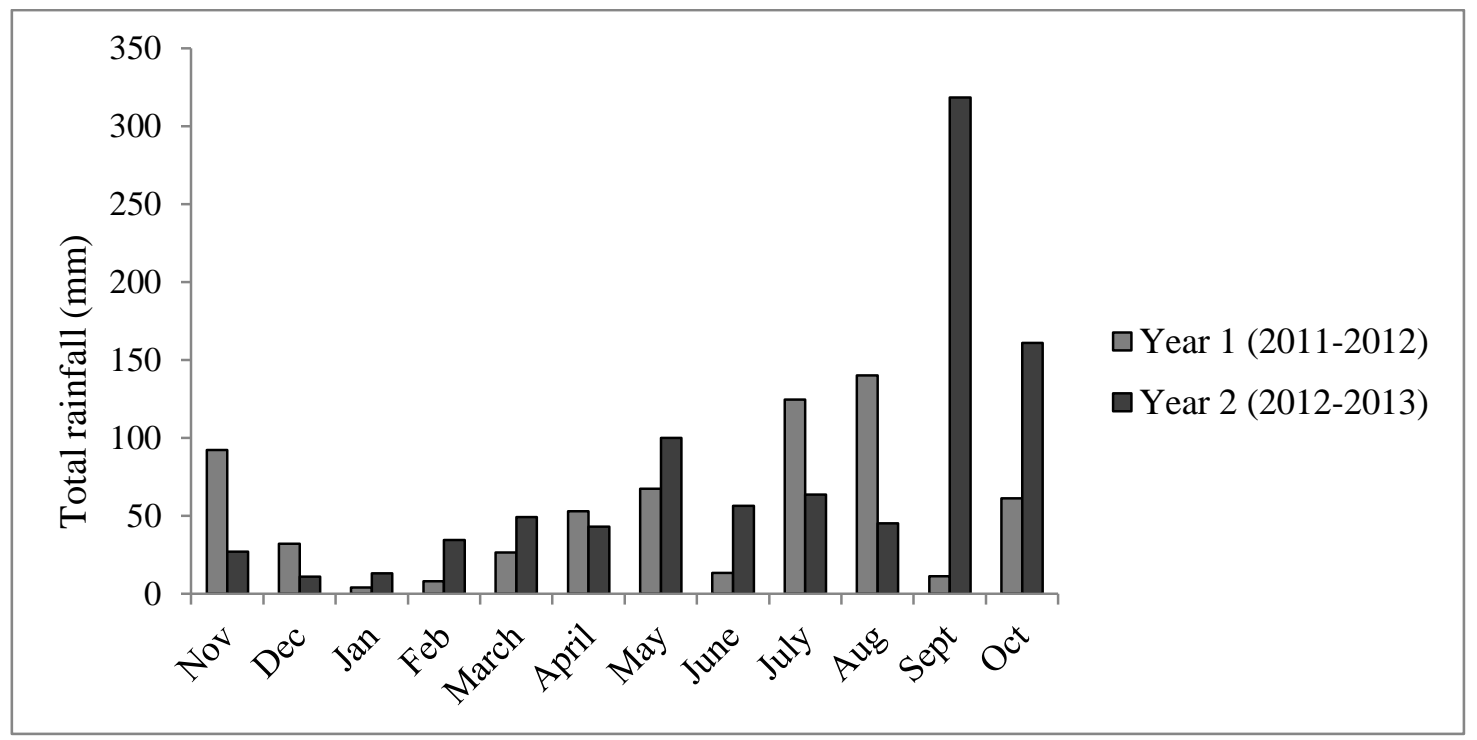

Figure A.1 Monthly total precipitation ( $\mathrm{mm}$ ) during the experimental time period (October 2011 to 2013). Source: Jobos Bay National Estuarine Research Reserve; NOAA Centralized Data Management Office; http://cdmo.baruch.sc.edu 


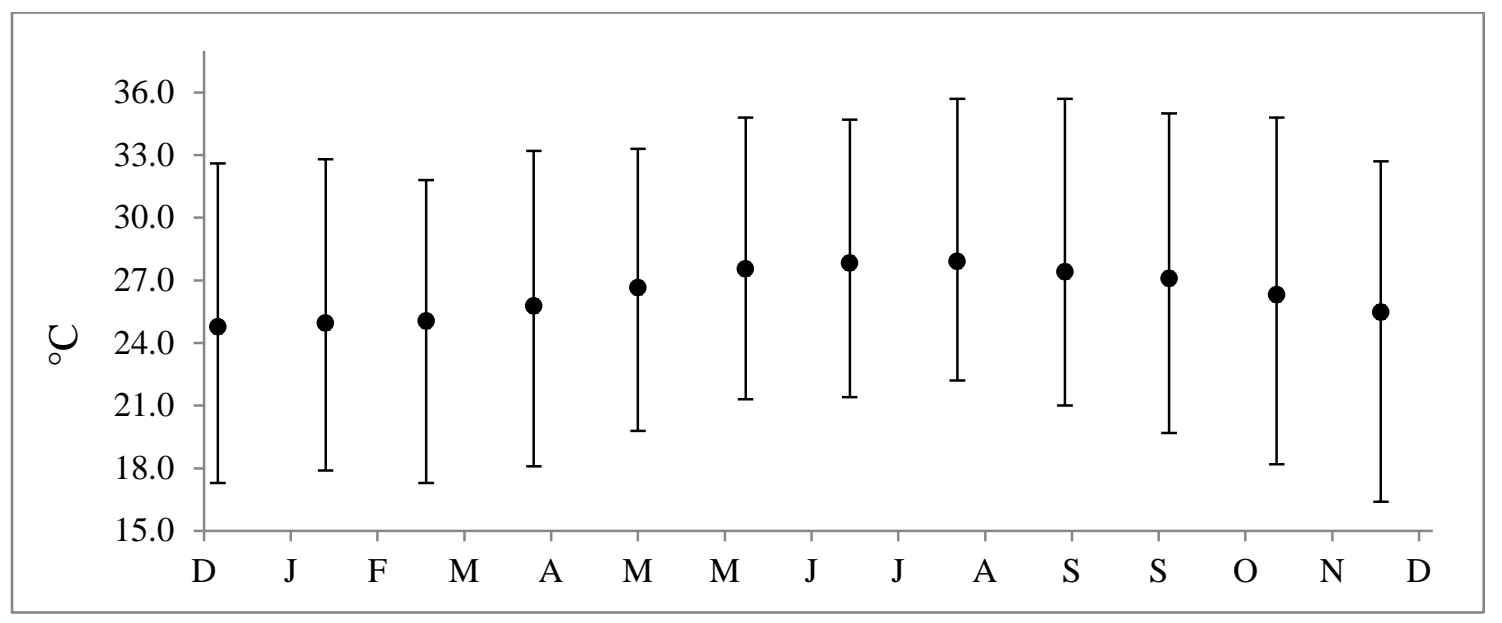

Figure A.2 Monthly average temperature (average, minimum, and maximum) at the Jobos Bay National Estuarine Research Reserve from 2007 to 2014. Data source: NOAA-NERR Centralized Data Management Office; http://cdmo.baruch.sc.edu 

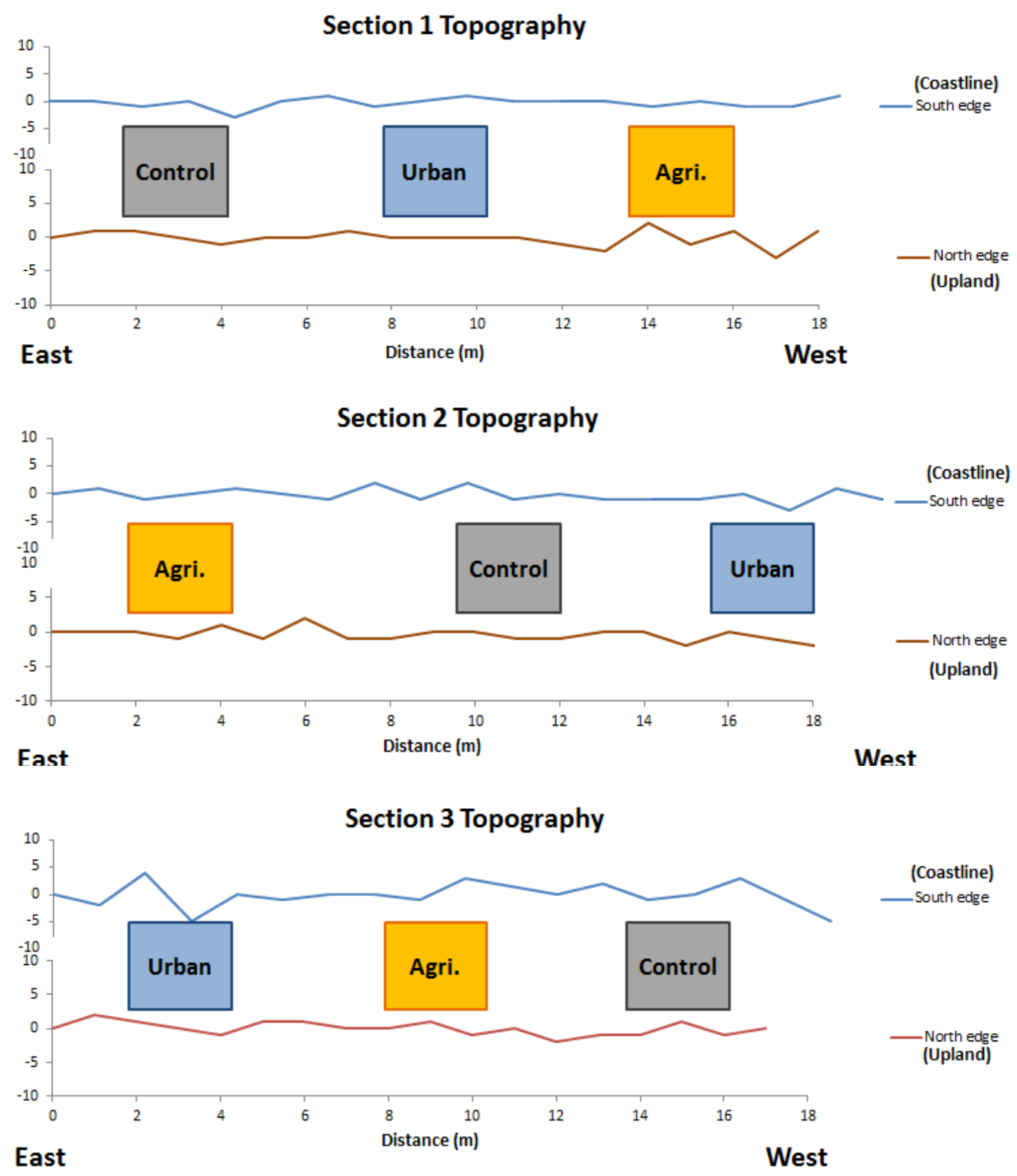

Figure A.3 Topography measurements for sections 1, 2, and 3, with experimental unit locations within each section. Two east-west transects were measured along the southern and northern boundaries of each section using two graduated poles and a hand level. Note that " 0 " is a relative point within a section (the starting height of the first pole location) and not necessarily the same absolute height between sections. The sections were located parallel to the coastline, approximately $5 \mathrm{~m}$ inland. 

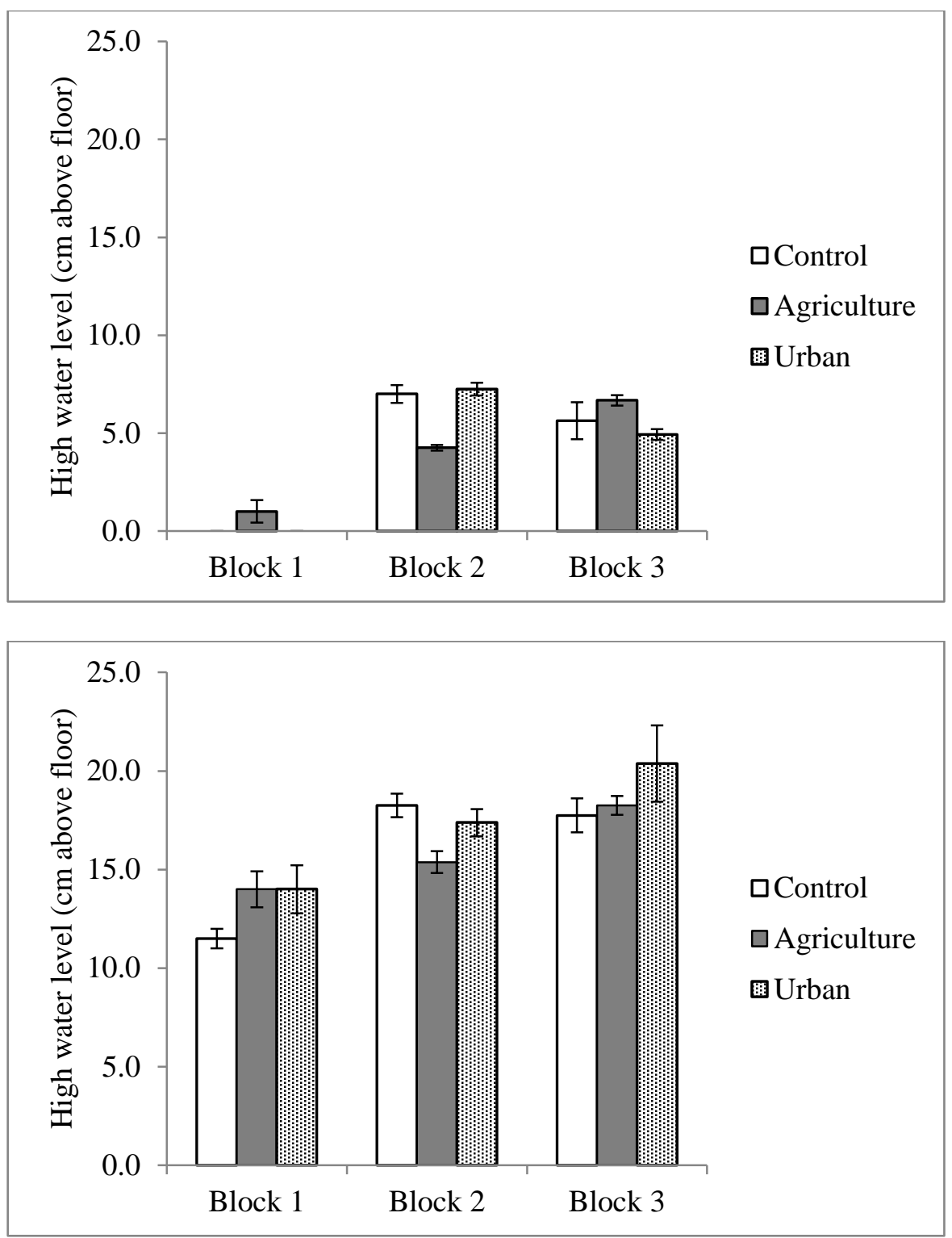

Figure A.4 Average high water levels of each quadrat in (A) March and (B) October, 2012, which represent the lowest and highest tidal ranges within a year (Field, 2008). High water levels were measured using water-based dye and glue and graduated poles. 


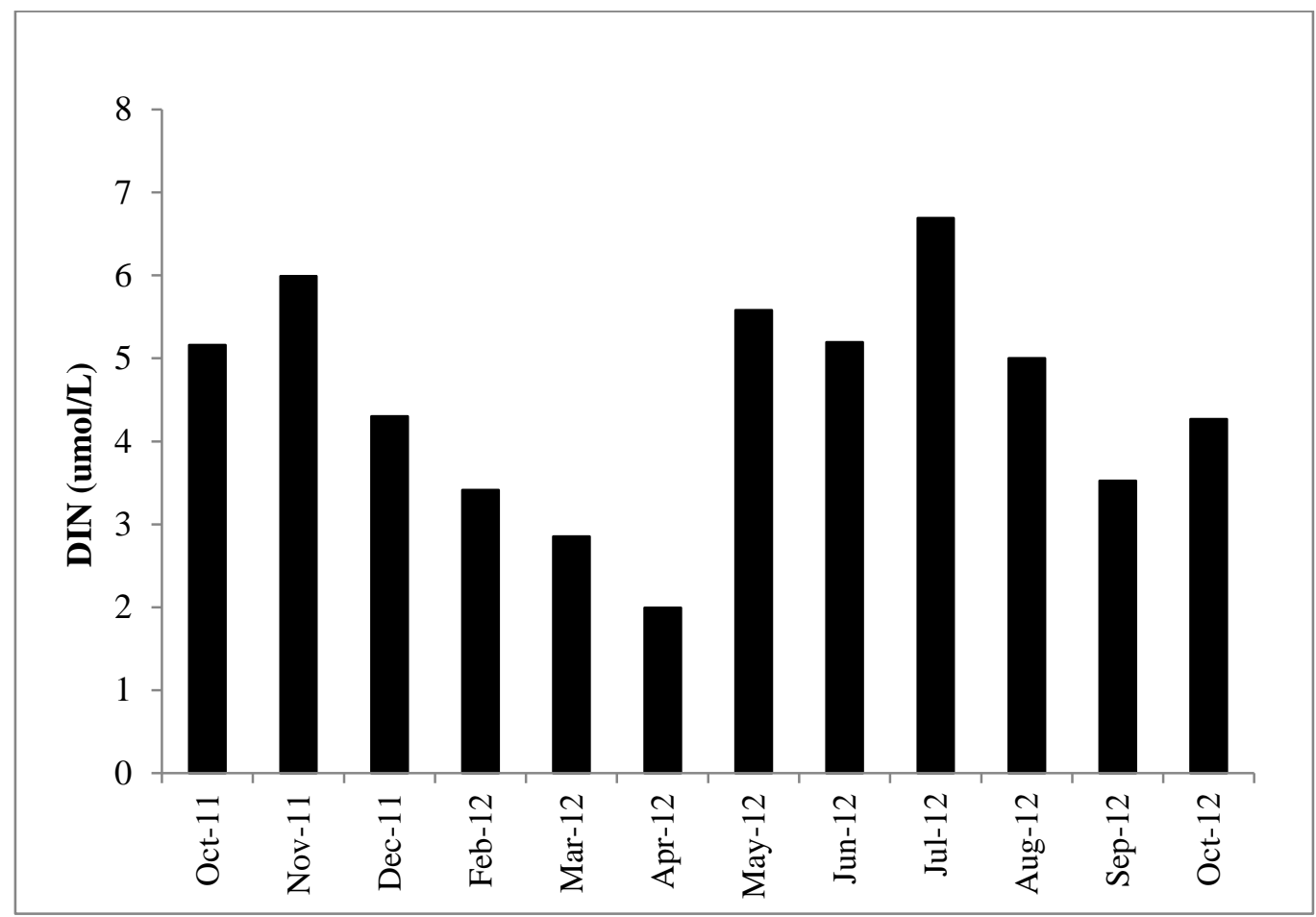

Figure A.5 Average monthly DIN concentrations during the first year of the experiment (October 2011 to October 2012) at Station 20, located at the southeastern mouth of Jobos Bay and upstream of the mangrove nutrient enrichment sites. Data source: NOAA Centralized Data Management Office; http://cdmo.baruch.sc.edu 


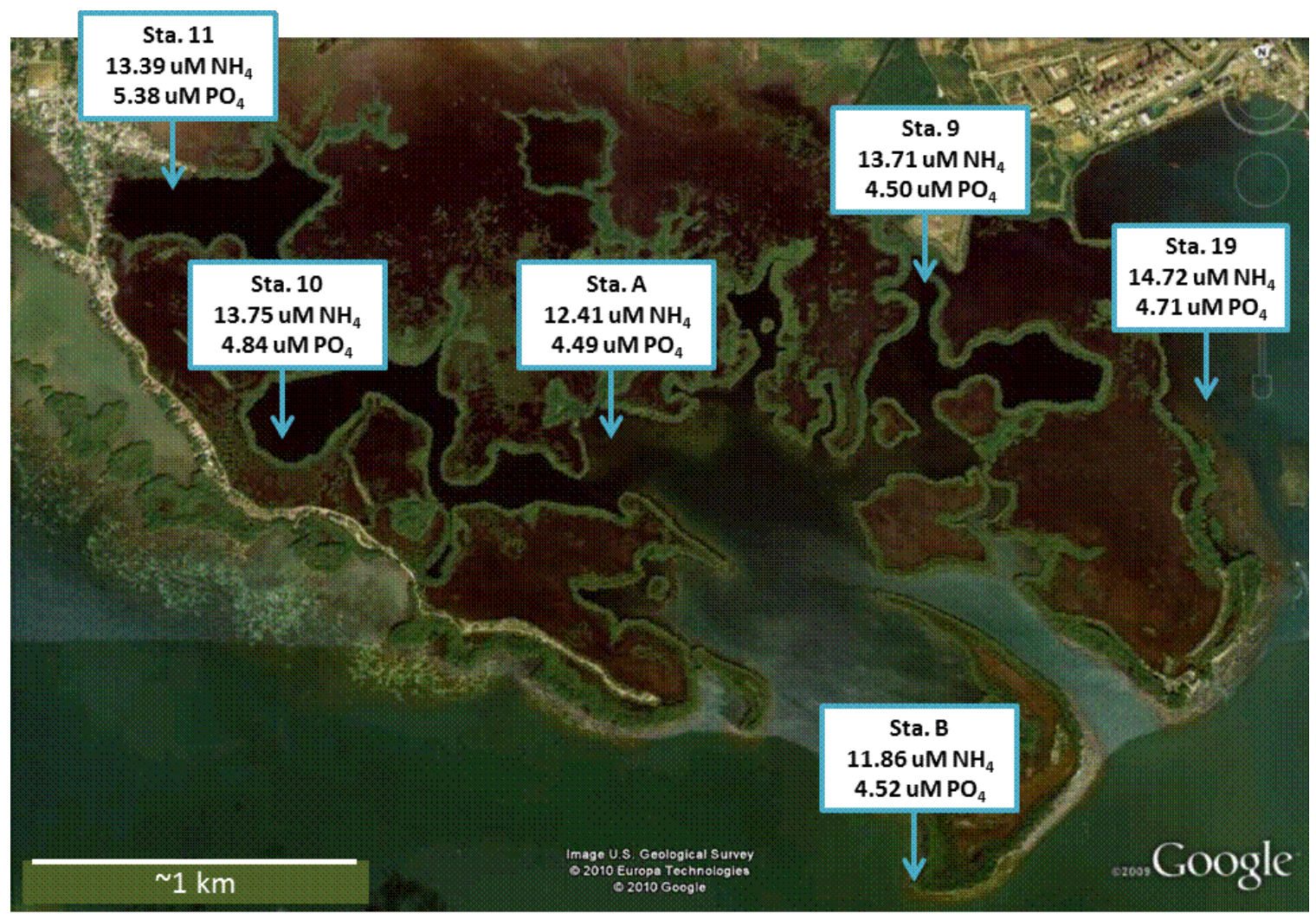

Figure A.6 Inorganic nutrient measurements from samples collected at Jobos Bay National Estuarine Research Reserve monitoring stations in January, 2013. Samples were collected in acid-washed opaque bottles and immediately frozen until analysis. 


\begin{tabular}{llccccc}
\hline \multicolumn{1}{c}{ Treatment } & Sample & $\mathrm{NH}_{4}{ }^{+}$ & $\mathrm{NO}_{2} \& \mathrm{NO}_{3}$ & Total DIN & Ortho-PO & $\mathrm{N}: \mathrm{P}$ \\
\hline Control & 1 & 6.42 & 3.85 & 10.27 & 2.86 & 3.59 \\
& 2 & 7.22 & 3.03 & 10.25 & 4.45 & 2.30 \\
& 3 & 9.02 & 1.08 & 10.10 & 4.79 & 2.11 \\
Average (S.E.) & & $7.55(0.77)$ & $2.65(0.82)$ & $10.21(0.05)$ & $4.03(0.59)$ & $2.67(0.47)$ \\
Urban & 1 & 15.60 & 3.52 & 19.12 & 15.60 & 1.23 \\
& 2 & 11.61 & 2.91 & 14.52 & 11.61 & 1.25 \\
& 3 & 18.40 & 1.27 & 19.67 & 18.40 & 1.07 \\
Average (S.E.) & & $15.20(1.97)$ & $2.57(0.67)$ & $17.77(1.63)$ & $15.20(1.97)$ & $1.18(0.06)$ \\
\hline
\end{tabular}

Figure A.7 Inorganic nutrient concentrations in flood waters that are overlying the control and urban nutrient enriched quadrats at block 2. These samples were taken at slack high tide in January, 2012, 14 days after the previous nutrient spray. Samples were frozen until analyzed. 


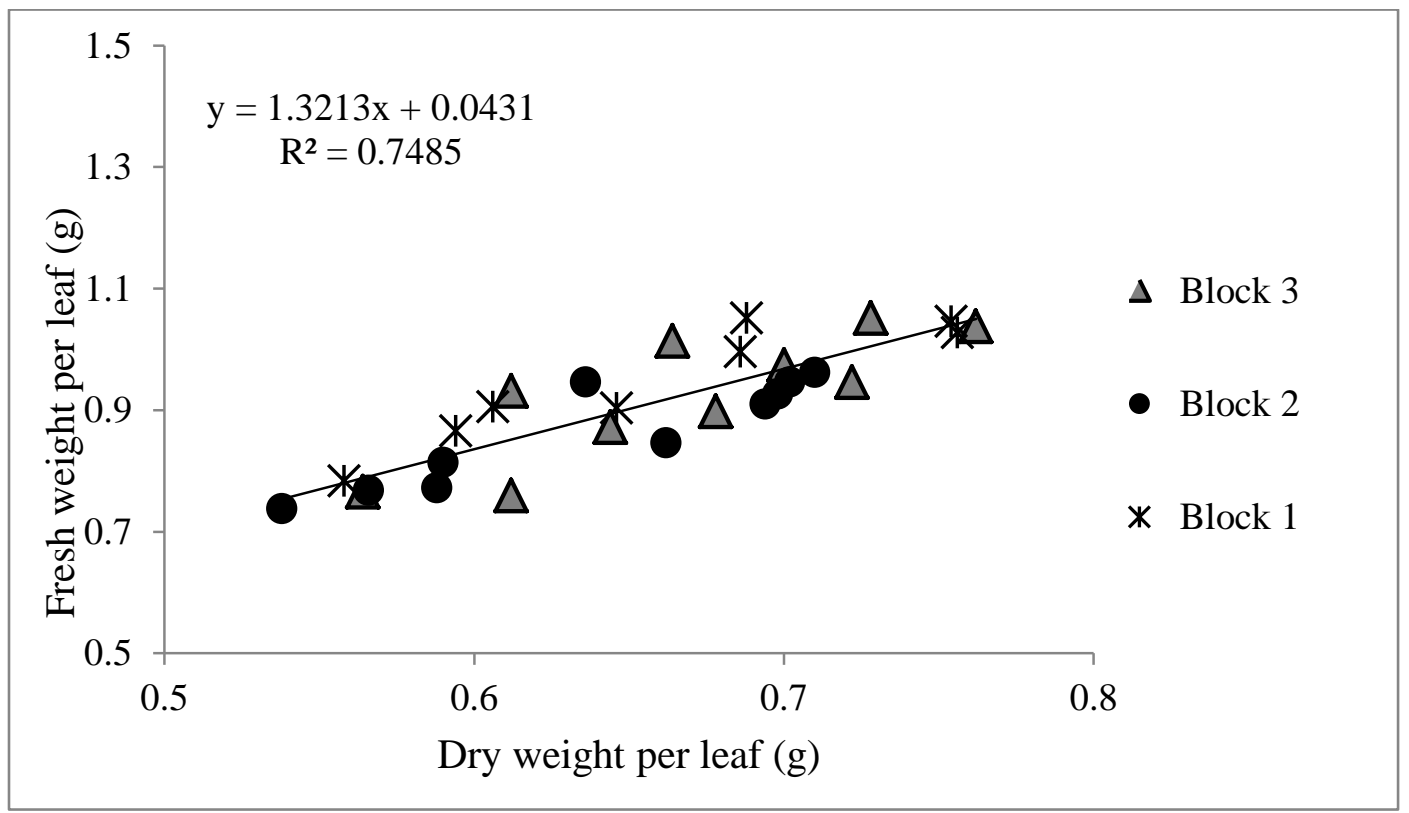

Figure A.8 Fresh-to-dry weight ratios of standing leaf litter collected in areas closely surrounding the experimental sites. Approximately 50 leaves were collected per block, rinsed with distilled water, air dried, and weighed ("fresh weight") before drying at $45 \mathrm{C}^{\circ}$ for a final "dry weight." A linear regression was used to determine the fresh-to-dry ratio for calculating final dry mass of collected decomposed litter into fresh weight for a comparison with initial mass (See Ch. 1, Methods). 

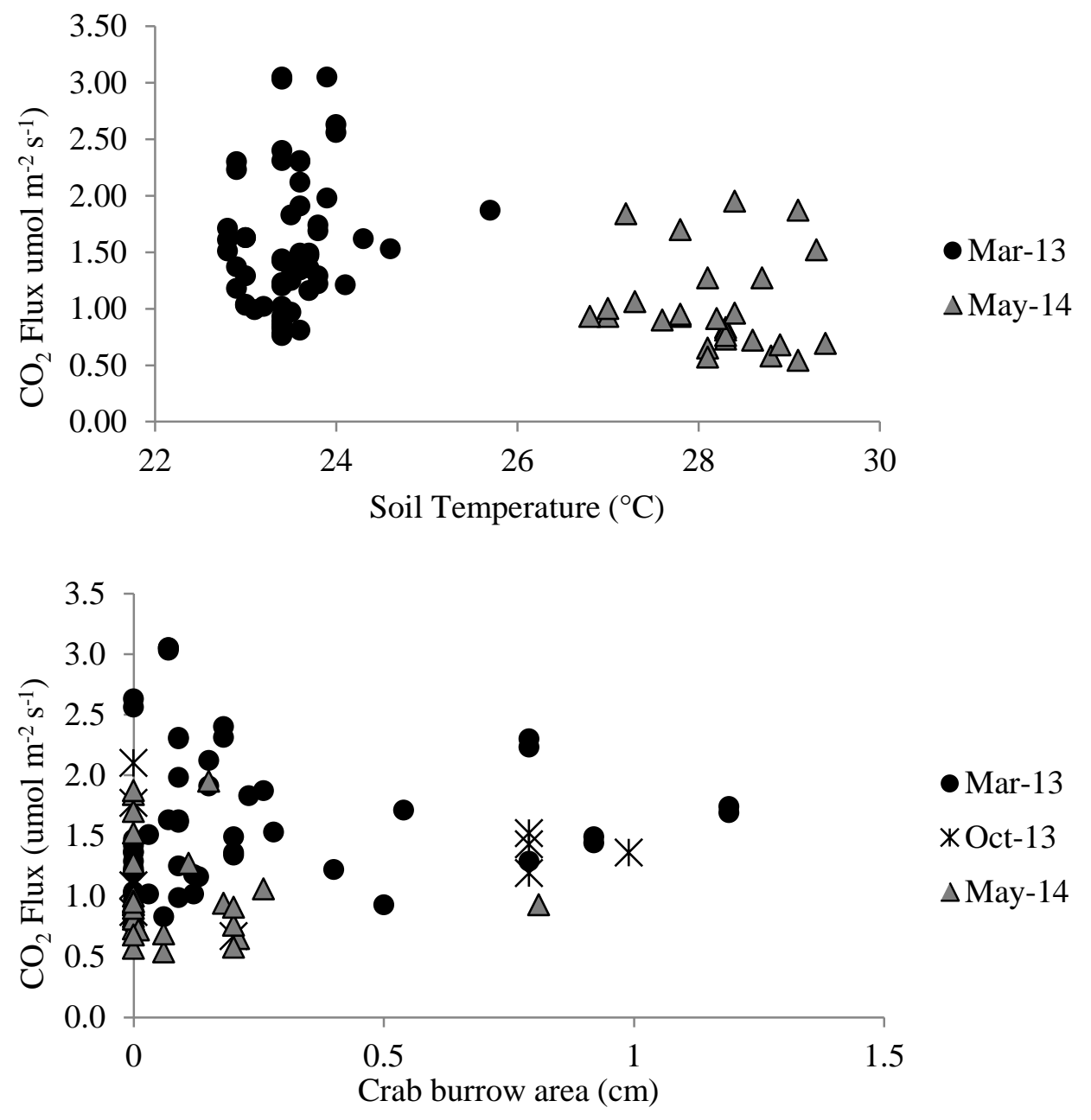

Figure A.9 Sediment respiration rates ( $\mu$ mol $\mathrm{CO}_{2} \mathrm{~m}^{-2} \mathrm{~s}^{-1}$ ) compared with (A) surface sediment (1 to $2 \mathrm{~cm}$ ) temperature and (B) crab burrow area of the quadrat. Sediment respiration was measured with an infra-red gas analyzer. Soil temperature was measured with a temperature probe. Crab burrows were measured by counting and measuring the diameter of all crab burrows within a 20x20 cm quadrat, and scaling to the quadrat area $\left(4 \mathrm{~m}^{2}\right)$. 


\section{Appendix B: Litterfall data}

Litterfall collection and processing is described in the Methods section of Chapter

2. Briefly, two litter collection baskets $\left(0.25 \mathrm{~m}^{2}\right)$ per quadrat were harvested every-other week during the study period. Recovered litter was sorted into components (leaves, propagules and flowers, stipules, wood, miscellaneous), dried, and weighed. All values reported here are g dry mass $\mathrm{m}^{-2} \mathrm{~d}^{-1}$. 
Propagules \&

Date Block Treatment Basket Leaves

10/6/2011 1 Agriculture $\quad 1 \quad 1.44$

10/6/2011 1 Agriculture $2 \quad 1.00$

10/6/2011 2 Agriculture 1101.49

10/6/2011 2 Agriculture $2 \quad 1.84$

10/6/2011 3 Agriculture 113.09

10/6/2011 3 Agriculture $\quad 2 \quad 4.30$

10/6/2011 1 Control $\quad 1 \quad 1.58$

10/6/2011 1 Control $\quad 2 \quad 1.44$

10/6/2011 2 Control $\quad 1 \quad 1.95$

10/6/2011 2 Control $\quad 2 \quad 1.80$

10/6/2011 3 Control $\quad 1 \quad 2.53$

10/6/2011 3 Control $\quad 2 \quad 1.50$

10/6/2011 1 Urban $\quad 1 \quad 1.68$

$\begin{array}{lllll}10 / 6 / 2011 & 1 & \text { Urban } & 2 & 0.16\end{array}$

10/6/2011 2 Urban $\quad 1 \quad 1.15$

10/6/2011 2 Urban $\quad 2 \quad 1.69$

$\begin{array}{lllll}10 / 6 / 2011 & 3 & \text { Urban } & 1 & 2.02\end{array}$

10/6/2011 3 Urban $\quad 2 \quad 1.89$

10/27/2011 1 Agriculture

10/27/2011 1 Agriculture

10/27/2011 2 Agriculture

10/27/2011 2 Agriculture

10/27/2011 3 Agriculture

10/27/2011 3 Agriculture

10/27/2011 1 Control

10/27/2011 1 Control 2

10/27/2011 2 Control 1

10/27/2011 2 Control

10/27/2011 3 Control

10/27/2011 3 Control

10/27/2011 1 Urban

10/27/2011 1 Urban

10/27/2011 2 Urban

10/27/2011 2 Urban

10/27/2011 3 Urban

10/27/2011 3 Urban

11/10/2011 1 Agriculture

11/10/2011 1 Agriculture

11/10/2011 2 Agriculture

11/10/2011 2 Agriculture

11/10/2011 3 Agriculture
Flowers

0.31

0.17

0.16

0.29

0.00

0.93

0.18

0.00

0.44

0.27

1.51

3.23

0.96

0.18

0.49

0.52

0.45

1.01

0.06

0.19

0.17

1.51

1.55

2.11

1.84

0.49

0.32

0.32

2.23

1.20

1.23

0.12

0.09

0.17

0.14

0.55

0.44

0.08

0.19

1.04

0.00

0.04

0.05

0.11
Stipules Wood Misc

$\begin{array}{lll}0.24 & 0.00 & 0.32\end{array}$

$\begin{array}{lll}0.46 & 0.00 & 0.38\end{array}$

$\begin{array}{lll}0.28 & 0.00 & 0.11\end{array}$

$\begin{array}{lll}0.20 & 0.00 & 0.15\end{array}$

$\begin{array}{lll}0.00 & 0.00 & 0.00\end{array}$

$\begin{array}{lll}0.22 & 0.16 & 0.07\end{array}$

$\begin{array}{lll}0.26 & 0.00 & 0.08\end{array}$

$\begin{array}{lll}0.14 & 0.00 & 0.00\end{array}$

$\begin{array}{llll}0.25 & 0.00 & 0.26\end{array}$

$\begin{array}{lll}0.23 & 0.00 & 0.24\end{array}$

$\begin{array}{llll}0.21 & 0.00 & 0.07\end{array}$

0.23

$\begin{array}{ll}0.00 & 0.14\end{array}$

$0.27 \quad 0.10$

$0.00 \quad 0.16$

$0.00 \quad 0.20$

$0.00 \quad 0.70$

$\begin{array}{ll}0.00 & 0.22\end{array}$

$\begin{array}{ll}0.00 & 0.23\end{array}$

$0.00 \quad 0.15$

$\begin{array}{ll}0.07 & 0.07\end{array}$

$0.00 \quad 0.12$

0.10

0.28

0.24

$\begin{array}{ll}0.00 & 0.12\end{array}$

$\begin{array}{ll}0.29 & 0.27\end{array}$

$\begin{array}{lll}0.13 & 0.00 & 0.04\end{array}$

Total

litterfall

2.31

2.01

2.03

2.48

3.09

5.67

2.10

1.59

2.90

2.54

4.31

5.10

3.09

0.50

2.07

3.12

2.75

3.38

3.73

2.42

1.89

2.44

3.24

2.33

$\begin{array}{lll}0.11 & 0.00 & 0.13\end{array}$

2.58

$\begin{array}{lll}0.21 & 0.00 & 0.06\end{array}$

1.56

$\begin{array}{lll}0.17 & 0.00 & 0.10\end{array}$

1.68

$\begin{array}{llll}0.27 & 0.03 & 0.16 & 1.94\end{array}$

$\begin{array}{llll}0.14 & 0.00 & 0.27 & 2.60\end{array}$

$\begin{array}{lll}0.14 & 0.00 & 0.26\end{array}$

2.30

$\begin{array}{llll}0.10 & 1.20 & 0.08 & 3.00\end{array}$

$\begin{array}{llll}0.19 & 1.13 & 0.12 & 2.79\end{array}$

$\begin{array}{lll}0.29 & 0.00 & 0.14\end{array}$

6.03

$\begin{array}{lll}0.27 & 0.00 & 0.03\end{array}$

2.15

$\begin{array}{lll}0.08 & 0.04 & 0.04\end{array}$

1.22

$\begin{array}{lll}0.19 & 0.00 & 0.16\end{array}$

2.15

$\begin{array}{llll}0.23 & 0.00 & 0.19 & 2.35\end{array}$ 
Propagules \&

Total

Date Block Treatment Basket Leaves

11/10/2011 3 Agriculture $\quad 2 \quad 2.86$

11/10/2011 1 Control $\quad 1 \quad 1.63$

11/10/2011 1 Control $\quad 2 \quad 1.79$

11/10/2011 2 Control

11/10/2011 2 Control

11/10/2011 3 Control

11/10/2011 3 Control

11/10/2011 1 Urban

11/10/2011 1 Urban

$11 / 10 / 2011 \quad 2$ Urban

$11 / 10 / 2011 \quad 2$ Urban

11/10/2011 3 Urban

11/10/2011 3 Urban

12/6/2011 1 Agriculture

12/6/2011 1 Agriculture

12/6/2011 2 Agriculture

12/6/2011 2 Agriculture

12/6/2011 3 Agriculture

12/6/2011 3 Agriculture

12/6/2011 1 Control

12/6/2011 1 Control

12/6/2011 2 Control

12/6/2011 2 Control

12/6/2011 3 Control

12/6/2011 3 Control

12/6/2011 1 Urban

12/6/2011 1 Urban

$12 / 6 / 2011 \quad 2$ Urban

12/6/2011 2 Urban

12/6/2011 3 Urban

$12 / 6 / 2011 \quad 3$ Urban

12/22/2011 1 Agriculture

$12 / 22 / 2011 \quad 1 \quad$ Agriculture

12/22/2011 2 Agriculture

$12 / 22 / 2011 \quad 2$ Agriculture 2

12/22/2011 3 Agriculture

12/22/2011 3 Agriculture

12/22/2011 1 Control

12/22/2011 1 Control 2

12/22/2011 2 Control
Flowers

$$
0.21
$$

0.04

0.21

$2 \quad 1.15$

12.86

$2 \quad 2.03$

1

$2 \quad 1.23$

$1 \quad 1.47$

21.62

$1 \quad 2.53$

$2 \quad 1.51$

10.59

$2 \quad 0.33$

$1 \quad 0.31$

$2 \quad 0.40$

$1 \quad 1.33$

21.31

1.06

$2 \quad 0.49$

10.85

20.53

$1 \quad 0.69$

$2 \quad 0.63$

$1 \quad 0.41$

$2 \quad 0.41$

$1 \quad 0.87$

20.38

$1 \quad 0.51$

$2 \quad 0.28$

$1 \quad 1.59$

$2 \quad 1.21$

$1 \quad 1.12$

2

$1 \quad 1.58$

$2 \quad 2.22$

10.56

2

$1 \quad 1.96$

$$
0.10
$$

0.03

0.21

0.07

0.43

0.47

0.00

0.04

0.09

0.02

0.00

0.10

0.08

0.07

0.01

0.04

0.15

0.18

0.00

0.02

0.00

0.02

0.05

0.06

0.12

0.06

0.15

0.00

0.14

0.46

0.88

0.00
0.10

Stipules Wood Misc

$\begin{array}{lll}0.17 & 0.00 & 0.38\end{array}$

$\begin{array}{lll}0.26 & 0.00 & 0.07\end{array}$

$\begin{array}{lll}0.42 & 0.02 & 0.10\end{array}$

3.62

1.99

2.54

$\begin{array}{llll}0.17 & 0.00 & 0.14 & 1.56\end{array}$

$\begin{array}{llll}0.04 & 0.00 & 0.02 & 2.94\end{array}$

$\begin{array}{llll}0.36 & 0.02 & 0.23 & 2.85\end{array}$

$\begin{array}{llll}0.24 & 0.03 & 0.09 & 1.66\end{array}$

$\begin{array}{lll}0.10 & 0.03 & 0.18\end{array}$

2.20

$\begin{array}{lll}0.10 & 0.00 & 0.33\end{array}$

2.52

$\begin{array}{llll}0.15 & 0.00 & 0.24 & 2.91\end{array}$

$\begin{array}{llll}0.24 & 0.00 & 0.07 & 1.86\end{array}$

$\begin{array}{llll}0.12 & 0.00 & 0.07 & 0.88\end{array}$

$\begin{array}{llll}0.04 & 0.00 & 0.05 & 0.45\end{array}$

$\begin{array}{lll}0.10 & 0.00 & 0.01\end{array}$

0.42

$\begin{array}{lll}0.08 & 0.00 & 0.05\end{array}$

0.62

$\begin{array}{lll}0.12 & 0.00 & 0.13\end{array}$

1.66

0.13

$0.00 \quad 0.16$

1.68

0.06

$0.00 \quad 0.05$

1.17

0.05

$\begin{array}{ll}0.00 & 0.04\end{array}$

0.63

0.08

$\begin{array}{ll}0.00 & 0.33\end{array}$

1.40

$\begin{array}{lll}0.11 & 0.00 & 0.14\end{array}$

0.96

0.05

$\begin{array}{ll}0.00 & 0.03\end{array}$

0.77

0.16

$\begin{array}{ll}0.00 & 0.07\end{array}$

0.88

0.18

$\begin{array}{ll}0.00 & 0.07\end{array}$

0.66

$\begin{array}{lll}0.09 & 0.02 & 0.07\end{array}$

0.60

0.13

$\begin{array}{ll}0.00 & 0.12\end{array}$

1.17

0.10

$\begin{array}{ll}0.00 & 0.11\end{array}$

0.64

$\begin{array}{lll}0.03 & 0.18 & 0.07\end{array}$

0.91

0.13

$0.03 \quad 0.04$

0.54

0.13

$\begin{array}{ll}0.00 & 0.12\end{array}$

1.98

$\begin{array}{llll}0.02 & 0.01 & 0.12 & 1.36\end{array}$

0.14

$0.00 \quad 0.04$

1.44

$\begin{array}{llll}0.12 & 0.01 & 0.16 & 2.33\end{array}$

$\begin{array}{llll}0.12 & 0.00 & 0.15 & 3.37\end{array}$

$\begin{array}{llll}0.13 & 0.06 & 0.05 & 0.80\end{array}$

$\begin{array}{lll}0.08 & 0.02 & 0.08\end{array}$

2.24 
Propagules \&

Date Block Treatment Basket Leaves

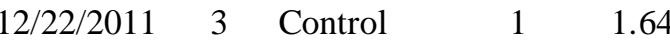

12/22/2011 3 Control $\quad 2 \quad 1.94$

12/22/2011 1 Urban $\quad 1 \quad 0.85$

$12 / 22 / 2011 \quad 1 \quad$ Urban $\quad 2 \quad 1.03$

$\begin{array}{lllll}12 / 22 / 2011 & 2 & \text { Urban } & 1 & 1.39\end{array}$

$\begin{array}{lllll}12 / 22 / 2011 & 2 & \text { Urban } & 2 & 0.83\end{array}$

12/22/2011 3 Urban $\quad 1 \quad 0.33$

$12 / 22 / 2011 \quad 3 \quad$ Urban $\quad 2 \quad 1.31$

3/10/2012 1 Agriculture 110.58

3/10/2012 1 Agriculture $\quad 2 \quad 2.70$

$\begin{array}{lllll}3 / 10 / 2012 & 2 & \text { Agriculture } & 1 & 0.97\end{array}$

3/10/2012 2 Agriculture $2 \quad 1.06$

3/10/2012 3 Agriculture $\begin{array}{lll}1 & 2.20\end{array}$

3/10/2012 3 Agriculture $2 \quad 1.80$

3/10/2012 1 Control $\quad 1 \quad 1.35$

3/10/2012 1 Control $\quad 2 \quad 0.89$

3/10/2012 2 Control $\quad 1 \quad 1.24$

3/10/2012 2 Control 221.06

3/10/2012 3 Control $\quad 1 \quad 2.13$

3/10/2012 3 Control $\quad 2 \quad 1.57$

$\begin{array}{lllll}3 / 10 / 2012 & 1 & \text { Urban } & 1 & 2.05\end{array}$

3/10/2012 1 Urban $\quad 2 \quad 1.99$

3/10/2012 2 Urban $\quad 114$

$\begin{array}{lllll}3 / 10 / 2012 & 2 & \text { Urban } & 2 & 1.44\end{array}$

3/10/2012 3 Urban $\quad 1 \quad 3.23$

$\begin{array}{lllll}3 / 10 / 2012 & 3 & \text { Urban } & 2 & 1.26\end{array}$

3/15/2012 1 Agriculture 110.66

3/15/2012 1 Agriculture 20.92

$\begin{array}{lllll}3 / 15 / 2012 & 2 & \text { Agriculture } & 1 & 0.62\end{array}$

$\begin{array}{lllll}3 / 15 / 2012 & 2 & \text { Agriculture } & 2 & 0.31\end{array}$

3/15/2012 3 Agriculture 1101.48

3/15/2012 3 Agriculture $\quad 2 \quad 1.40$

$\begin{array}{lllll}3 / 15 / 2012 & 1 & \text { Control } & 1 & 2.72\end{array}$

3/15/2012 1 Control $\quad 2 \quad 1.46$

$\begin{array}{lllll}3 / 15 / 2012 & 2 & \text { Control } & 1 & 1.14\end{array}$

$\begin{array}{lllll}3 / 15 / 2012 & 2 & \text { Control } & 2 & 2.14\end{array}$

$\begin{array}{lllll}3 / 15 / 2012 & 3 & \text { Control } & 1 & 0.91\end{array}$

$\begin{array}{lllll}3 / 15 / 2012 & 3 & \text { Control } & 2 & 0.88\end{array}$

$\begin{array}{lllll}3 / 15 / 2012 & 1 & \text { Urban } & 1 & 0.26\end{array}$

$\begin{array}{lllll}3 / 15 / 2012 & 1 & \text { Urban } & 2 & 1.99\end{array}$
Flowers

0.11

0.00

0.21

0.26

0.14

0.05

0.33

0.00

0.23

0.00

0.14

0.50

0.02

0.17

0.03

0.02

0.06

0.19

0.00

0.47

0.06

0.00

0.00

0.06

0.37

0.02

0.18

0.07

0.00

0.00

0.00

0.25

0.08

0.00

0.10

0.00

0.00

0.00

0.00

0.00

0.00
Stipules Wood Misc

0.06

0.16

0.08

0.14

0.15

0.12

0.02

0.02

0.04

0.13

0.20

0.13

0.11

0.20

0.01

0.22

0.21

0.06

0.00

0.04

0.01

0.11

0.06

0.03

0.06

0.07

0.03

0.09

0.10

0.06

0.03

0.06

0.00

0.00

0.00

0.00

0.14

0.00

0.09

0.00

0.15 $\begin{array}{ll}0.00 & 0.07\end{array}$

$0.08 \quad 0.14$

$\begin{array}{ll}0.00 & 0.17\end{array}$

$0.00 \quad 0.14$

$\begin{array}{ll}0.00 & 0.13\end{array}$

$\begin{array}{ll}0.00 & 0.02\end{array}$

$0.00 \quad 0.10$

$0.00 \quad 0.06$

$\begin{array}{ll}0.00 & 0.03\end{array}$

$0.00 \quad 0.00$

$0.00 \quad 0.11$

$0.00 \quad 0.05$

$0.00 \quad 0.05$

$0.00 \quad 0.08$

$0.00 \quad 0.03$

$\begin{array}{ll}0.01 & 0.02\end{array}$

$0.34 \quad 0.12$

$0.00 \quad 0.11$

$0.00 \quad 0.00$

$\begin{array}{ll}0.15 & 0.07\end{array}$

$0.00 \quad 0.04$

$0.04 \quad 0.03$

$0.00 \quad 0.04$

$0.19 \quad 0.07$

$0.01 \quad 0.10$

$0.05 \quad 0.04$

$0.00 \quad 0.01$

$0.02 \quad 0.08$

$0.00 \quad 0.22$

$0.00 \quad 0.03$

$2.03 \quad 0.13$

$0.00 \quad 0.06$

$0.00 \quad 0.16$

$0.00 \quad 0.02$

$0.04 \quad 0.10$

$0.00 \quad 0.41$

$\begin{array}{ll}0.00 & 0.24\end{array}$

$\begin{array}{ll}0.00 & 0.07\end{array}$

$0.23 \quad 0.00$

$0.01 \quad 0.12$

$0.66 \quad 0.10$
Total

litterfall

2.03

2.01

2.39

1.40

1.45

1.58

1.27

0.40

1.60

0.71

3.15

1.65

1.23

2.64

1.87

1.61

1.61

1.60

1.06

2.85

1.68

2.23

2.09

1.50

1.98

3.42

1.48

0.93

1.24

0.71

2.50

1.85

1.64

2.74

1.70

1.54

2.51

0.98

1.20

0.39

2.90 
Propagules \&

Date Block Treatment Basket Leaves

3/15/2012 2 Urban

3/15/2012 3 Urban

3/15/2012 3 Urban

3/29/2012 1 Agriculture

3/29/2012 1 Agriculture

3/29/2012 2 Agriculture

3/29/2012 2 Agriculture

$3 / 29 / 20123$ Agriculture

3/29/2012 3 Agriculture

3/29/2012 1 Control

3/29/2012 1 Control

3/29/2012 2 Control

3/29/2012 2 Control

3/29/2012 3 Control

3/29/2012 3 Control

3/29/2012 1 Urban

3/29/2012 1 Urban

3/29/2012 2 Urban

3/29/2012 2 Urban

$3 / 29 / 2012 \quad 3$ Urban

3/29/2012 3 Urban

4/12/2012 1 Agriculture

4/12/2012 1 Agriculture

4/12/2012 2 Agriculture

4/12/2012 2 Agriculture

4/12/2012 3 Agriculture

4/12/2012 3 Agriculture

4/12/2012 1 Control

4/12/2012 1 Control

4/12/2012 2 Control

4/12/2012 2 Control

4/12/2012 3 Control

4/12/2012 3 Control

4/12/2012 1 Urban

4/12/2012 1 Urban

4/12/2012 2 Urban

4/12/2012 2 Urban

$4 / 12 / 2012 \quad 3 \quad$ Urban

4/12/2012 3 Urban

4/25/2012 1 Agriculture

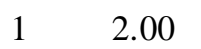

Flowers

0.00

0.00

0.00

0.00

0.09

0.17

0.01

0.00

0.01

0.14

0.44

0.11

0.04

0.45

0.00

0.42

0.05

0.03

0.00

0.00

0.95

0.02

0.31

0.09

0.00

0.00

0.00

0.00

0.03

0.02

0.00

0.27

0.00

0.07

0.01

0.00

0.00

0.06

0.00

0.00

0.04
Stipules Wood Misc

$\begin{array}{lll}0.21 & 0.00 & 0.05\end{array}$

$\begin{array}{lll}0.17 & 0.00 & 0.34\end{array}$

$\begin{array}{lll}0.00 & 0.00 & 0.02\end{array}$

$\begin{array}{lll}0.12 & 0.00 & 0.10\end{array}$

$\begin{array}{lll}0.20 & 0.00 & 0.03\end{array}$

$\begin{array}{lll}0.04 & 0.00 & 0.05\end{array}$

$\begin{array}{llll}0.09 & 0.00 & 0.01\end{array}$

$\begin{array}{lll}0.05 & 0.00 & 0.00\end{array}$

$\begin{array}{lll}0.04 & 0.00 & 0.04\end{array}$

$\begin{array}{lll}0.23 & 0.00 & 0.00\end{array}$

$\begin{array}{lll}0.00 & 0.00 & 0.05\end{array}$

$\begin{array}{lll}0.02 & 0.00 & 0.07\end{array}$

$\begin{array}{llll}0.04 & 0.00 & 0.03\end{array}$

$\begin{array}{llll}0.09 & 0.00 & 0.01\end{array}$

$\begin{array}{lll}0.16 & 0.00 & 0.11\end{array}$

$\begin{array}{llll}0.05 & 0.00 & 0.09\end{array}$

$\begin{array}{lll}0.09 & 0.66 & 0.04\end{array}$

$\begin{array}{lll}0.06 & 0.01 & 0.00\end{array}$

$\begin{array}{llll}0.09 & 0.00 & 0.00\end{array}$

$\begin{array}{llll}0.07 & 0.00 & 0.02\end{array}$

$\begin{array}{lll}0.08 & 0.00 & 0.08\end{array}$

$\begin{array}{llll}0.15 & 0.00 & 0.00\end{array}$

$\begin{array}{lll}0.27 & 0.01 & 0.02\end{array}$

$\begin{array}{lll}0.07 & 0.00 & 0.19\end{array}$

$\begin{array}{lll}0.12 & 0.00 & 0.00\end{array}$

$\begin{array}{llll}0.34 & 0.00 & 0.00\end{array}$

$\begin{array}{lll}0.24 & 0.00 & 0.09\end{array}$

0.40

0.01

$0.00 \quad 0.09$

$0.00 \quad 0.00$

$\begin{array}{lll}0.05 & 0.01 & 0.00\end{array}$

0.07

$0.78 \quad 0.00$

$\begin{array}{lll}0.11 & 0.00 & 0.07\end{array}$

$\begin{array}{lll}0.33 & 0.03 & 0.01\end{array}$

0.22

$\begin{array}{ll}0.01 & 0.22\end{array}$

0.13

$0.00 \quad 0.02$

$0.00 \quad 0.00$

0.07

0.15

$0.00 \quad 0.02$

0.26

$0.00 \quad 0.05$

$\begin{array}{lll}0.13 & 0.07 & 0.10\end{array}$

0.16

$0.00 \quad 0.04$

$\begin{array}{lll}0.21 & 0.00 & 0.03\end{array}$
Total

litterfall

2.26

3.69

3.42

1.21

1.51

1.87

0.54

0.83

3.10

2.50

0.97

1.17

1.75

1.62

0.84

1.92

1.87

1.63

0.90

1.04

1.65

1.23

2.25

1.73

1.52

1.58

1.13

3.91

0.81

0.73

2.44

2.96

1.33

1.64

2.84

1.76

1.24

1.80

1.43

0.88

2.86 
Propagules \&

Date Block Treatment Basket Leaves

4/25/2012 1 Agriculture $\quad 2 \quad 2.81$

4/25/2012 2 Agriculture 12.51

4/25/2012 2 Agriculture 220.76

4/25/2012 3 Agriculture 113.38

4/25/2012 3 Agriculture $2 \quad 2.95$

4/25/2012 1 Control $\quad 1 \quad 1.25$

4/25/2012 11 Control $\quad 2 \quad 2.34$

4/25/2012 2 Control $\quad 1 \quad 2.01$

4/25/2012 2 Control 23.53

4/25/2012 3 Control $\quad 1 \quad 1.49$

$\begin{array}{lllll}4 / 25 / 2012 & 3 & \text { Control } & 2 & 1.30\end{array}$

4/25/2012 1 Urban $\quad 1 \quad 1.43$

4/25/2012 1 Urban $\quad 2 \quad 1.22$

4/25/2012 2 Urban $\quad 1 \quad 2.54$

$4 / 25 / 2012 \quad 2 \quad$ Urban $\quad 2 \quad 1.30$

4/25/2012 3 Urban $\quad 1 \quad 3.83$

$\begin{array}{lllll}4 / 25 / 2012 & 3 & \text { Urban } & 2 & 1.75\end{array}$

5/17/2012 1 Agriculture 113.43

5/17/2012 1 Agriculture $2 \quad 2.22$

5/17/2012 2 Agriculture 112.51

5/17/2012 2 Agriculture $2 \quad 2.32$

5/17/2012 3 Agriculture $\quad 1 \quad 4.78$

5/17/2012 3 Agriculture $\quad 2 \quad 2.39$

5/17/2012 1 Control $\quad 1 \quad 1.86$

$\begin{array}{lllll}5 / 17 / 2012 & 1 & \text { Control } & 2 & 3.14\end{array}$

$\begin{array}{lllll}5 / 17 / 2012 & 2 & \text { Control } & 1 & 2.97\end{array}$

5/17/2012 2 Control $\quad 2 \quad 4.06$

5/17/2012 3 Control $\quad 1 \quad 2.92$

$\begin{array}{lllll}5 / 17 / 2012 & 3 & \text { Control } & 2 & 2.83\end{array}$

$\begin{array}{lllll}5 / 17 / 2012 & 1 & \text { Urban } & 1 & 2.11\end{array}$

$\begin{array}{lllll}5 / 17 / 2012 & 1 & \text { Urban } & 2 & 2.22\end{array}$

$\begin{array}{lllll}5 / 17 / 2012 & 2 & \text { Urban } & 1 & 2.24\end{array}$

5/17/2012 2 Urban $\quad 2 \quad 2.09$

$\begin{array}{lllll}5 / 17 / 2012 & 3 & \text { Urban } & 1 & 4.47\end{array}$

5/17/2012 3 Urban $\quad 2 \quad 2.72$

5/31/2012 1 Agriculture 112.79

5/31/2012 1 Agriculture $2 \quad 3.00$

5/31/2012 2 Agriculture 1101.50

5/31/2012 2 Agriculture $2 \quad 1.81$

5/31/2012 3 Agriculture $\quad 1 \quad 3.26$

$\begin{array}{lllll}5 / 31 / 2012 & 3 & \text { Agriculture } & 2 & 2.80\end{array}$
Flowers

$$
0.00
$$

0.00

0.07

0.24

0.03

0.02

0.00

0.91

0.02

0.00

1.26

0.96

0.00

0.03

1.16

0.00

0.00

0.00

0.00

0.00

0.04

0.03

0.09

0.00

0.05

2.29

0.00

0.25

0.55

0.00

0.00

0.02

0.06

0.00

0.01

0.03

0.02

0.40

0.00

0.28

0.17
Stipules Wood Misc

$\begin{array}{lll}0.19 & 0.33 & 0.03\end{array}$

$\begin{array}{lll}0.30 & 0.00 & 0.04\end{array}$

$\begin{array}{lll}0.11 & 0.00 & 0.11\end{array}$

$\begin{array}{lll}0.27 & 0.00 & 0.10\end{array}$

$\begin{array}{lll}0.32 & 0.00 & 0.10\end{array}$

$\begin{array}{lll}0.04 & 0.00 & 0.05\end{array}$

$\begin{array}{lll}0.00 & 0.03 & 0.02\end{array}$

$\begin{array}{lll}0.08 & 0.50 & 0.15\end{array}$

$\begin{array}{lll}0.20 & 0.00 & 0.09\end{array}$

$\begin{array}{llll}0.08 & 0.00 & 0.07\end{array}$

$\begin{array}{lll}0.05 & 0.00 & 0.23\end{array}$

$\begin{array}{lll}0.06 & 0.03 & 0.08\end{array}$

0.24

0.20

$0.00 \quad 0.05$

$\begin{array}{ll}0.00 & 0.17\end{array}$

0.22

$1.61 \quad 0.10$

$0.10 \quad 0.34$

$\begin{array}{ll}0.00 & 0.09\end{array}$

0.13

0.65

$0.00 \quad 0.11$

$0.95 \quad 0.13$

0.34

0.33

$0.00 \quad 0.04$

$0.00 \quad 0.11$

$0.08 \quad 0.17$

$\begin{array}{ll}0.07 & 0.04\end{array}$

$\begin{array}{ll}0.00 & 0.05\end{array}$

$\begin{array}{ll}0.83 & 0.07\end{array}$

$\begin{array}{ll}0.11 & 0.21\end{array}$

$\begin{array}{ll}0.00 & 0.07\end{array}$

$0.00 \quad 0.04$

$0.00 \quad 0.16$

$0.00 \quad 0.12$

$0.00 \quad 0.14$

$0.00 \quad 0.14$

$0.00 \quad 0.25$

$0.07 \quad 0.09$

$\begin{array}{ll}0.00 & 0.08\end{array}$

$0.16 \quad 0.04$

$0.00 \quad 0.10$

$0.00 \quad 0.12$

$0.63 \quad 0.10$

$0.02 \quad 0.38$

$0.06 \quad 0.29$
Total

litterfall

3.36

2.84

3.06

3.99

3.41

1.36

2.39

3.65

3.83

1.64

2.84

2.57

1.51

2.94

4.39

4.36

1.97

4.19

3.64

2.88

3.01

5.69

2.96

2.56

4.60

6.01

4.35

3.48

3.92

2.57

2.79

2.95

2.87

4.88

3.20

3.38

3.26

2.34

2.85

4.38

3.81 
Propagules \&

Date Block Treatment Basket Leaves

$\begin{array}{lllll}\text { 5/31/2012 } & 1 & \text { Control } & 1 & 0.75\end{array}$

$2 \quad 1.81$

5/31/2012 2 Control $\quad 1 \quad 3.25$

5/31/2012 2 Control $\quad 2 \quad 2.04$

5/31/2012 3 Control $\quad 1 \quad 1.88$

$\begin{array}{lllll}5 / 31 / 2012 & 3 & \text { Control } & 2 & 1.79\end{array}$

5/31/2012 1 Urban $\quad 1 \quad 2.73$

5/31/2012 1 Urban $\quad 2 \quad 3.66$

5/31/2012 2 Urban $\quad 1 \quad 1.72$

$5 / 31 / 2012 \quad 2 \quad$ Urban $\quad 2 \quad 3.49$

$\begin{array}{lllll}5 / 31 / 2012 & 3 & \text { Urban } & 1 & 7.31\end{array}$

5/31/2012 3 Urban $\quad 2 \quad 3.85$

6/13/2012 1 Agriculture 114.90

6/13/2012 1 Agriculture $2 \quad 2.92$

6/13/2012 2 Agriculture 113.16

6/13/2012 2 Agriculture $2 \quad 1.94$

6/13/2012 3 Agriculture 1

6/13/2012 3 Agriculture

6/13/2012 1 Control

6/13/2012 1 Control

6/13/2012 2 Control

6/13/2012 2 Control

6/13/2012 3 Control

6/13/2012 3 Control

6/13/2012 1 Urban

6/13/2012 1 Urban

6/13/2012 2 Urban

6/13/2012 2 Urban

6/13/2012 3 Urban

6/13/2012 3 Urban

6/27/2012 1 Agriculture

6/27/2012 1 Agriculture

6/27/2012 2 Agriculture

6/27/2012 2 Agriculture

6/27/2012 3 Agriculture

6/27/2012 3 Agriculture

6/27/2012 1 Control

6/27/2012 1 Control

6/27/2012 2 Control

6/27/2012 2 Control

6/27/2012 3 Control
Flowers

$$
0.00
$$

2.22

1.03

0.01

0.43

0.00

0.00

2.76

0.00

0.01

0.02

0.05

0.95

0.00

0.00

0.00

3.39

1.79

1.86

3.66

3.63

1.86

2.21

2.78

2.91

$1 \quad 2.18$

$2 \quad 2.02$

$1 \quad 5.37$

$2 \quad 3.42$

14.20

24.41

12.63

23.13

$1 \quad 2.80$

$2 \quad 5.15$

$1 \quad 1.94$

$2 \quad 3.97$

$1 \quad 2.31$

$2 \quad 2.58$

$1 \quad 2.71$

0.17

0.00

1.55

7.75

0.00

0.00

0.86

0.81

0.07

0.00

0.04

0.00

0.03

0.80

0.00

0.43

2.00

0.18

0.55

0.00

0.03

11.87

2.14

0.00
Stipules Wood Misc $\begin{array}{lll}0.53 & 0.00 & 0.05\end{array}$

$\begin{array}{lll}0.49 & 0.19 & 0.10\end{array}$

$\begin{array}{lll}0.31 & 0.00 & 0.47\end{array}$

$\begin{array}{lll}0.16 & 0.00 & 0.23\end{array}$

$\begin{array}{lll}0.14 & 0.26 & 0.25\end{array}$

$\begin{array}{lll}0.26 & 0.00 & 0.13\end{array}$

$\begin{array}{lll}0.23 & 0.00 & 0.08\end{array}$

$\begin{array}{lll}0.25 & 0.00 & 0.13\end{array}$

$\begin{array}{lll}0.30 & 0.00 & 0.05\end{array}$

$\begin{array}{lll}0.37 & 0.00 & 0.07\end{array}$

$\begin{array}{lll}0.17 & 0.00 & 0.39\end{array}$

$\begin{array}{lll}0.27 & 0.00 & 0.18\end{array}$

$\begin{array}{lll}0.18 & 0.00 & 0.05\end{array}$

$\begin{array}{lll}0.23 & 0.00 & 0.05\end{array}$

$\begin{array}{lll}0.14 & 0.00 & 0.00\end{array}$

$\begin{array}{lll}0.32 & 0.04 & 0.00\end{array}$

Total

litterfall

1.33

4.81

5.07

2.43

2.95

2.18

3.04

6.79

2.07

3.95

7.90

4.35

6.08

3.20

3.30

2.30

$\begin{array}{llll}0.42 & 0.00 & 0.00 & 3.98\end{array}$

$\begin{array}{lll}0.00 & 0.00 & 0.00\end{array}$

1.79

$\begin{array}{lll}0.15 & 0.00 & 0.06\end{array}$

3.62

$\begin{array}{lll}0.15 & 0.09 & 0.18\end{array}$

11.83

$\begin{array}{lll}0.13 & 0.00 & 0.05\end{array}$

3.82

$\begin{array}{lll}0.12 & 0.00 & 0.19\end{array}$

2.17

$\begin{array}{lll}0.27 & 0.00 & 0.00\end{array}$

3.34

0.21

$0.00 \quad 0.09$

3.89

0.22

$\begin{array}{ll}0.00 & 0.00\end{array}$

3.20

0.10

$\begin{array}{ll}0.05 & 0.11\end{array}$

2.45

0.18

$0.00 \quad 0.08$

2.32

$\begin{array}{lll}0.02 & 4.62 & 0.00\end{array}$

10.01

$\begin{array}{lll}0.21 & 0.04 & 0.02\end{array}$

3.72

$\begin{array}{lll}0.54 & 0.00 & 0.25\end{array}$

5.79

$\begin{array}{lll}0.33 & 0.03 & 0.40\end{array}$

5.17

$\begin{array}{lll}0.33 & 0.00 & 0.03\end{array}$

3.43

0.53

$0.00 \quad 0.04$

5.70

$\begin{array}{lll}0.31 & 0.00 & 0.30\end{array}$

3.60

$\begin{array}{lll}0.51 & 0.00 & 0.35\end{array}$

6.55

0.26

$0.00 \quad 0.05$

2.25

0.28

$\begin{array}{ll}0.02 & 0.12\end{array}$

4.42

0.09

$0.00 \quad 0.52$

14.79

0.11

$\begin{array}{ll}0.00 & 0.27\end{array}$

5.09

0.35

$\begin{array}{ll}0.01 & 0.03\end{array}$ 
Propagules \&

Total

Date Block Treatment Basket Leaves

Flowers

Stipules Wood Misc

litterfall

\begin{tabular}{|c|c|c|c|c|c|c|c|c|c|}
\hline 6/27/2012 & 3 & Control & 2 & 3.50 & 0.38 & 0.28 & 0.00 & 0.04 & 4.20 \\
\hline 6/27/2012 & 1 & Urban & 1 & 2.97 & 0.93 & 0.18 & 0.27 & 0.15 & 4.50 \\
\hline 6/27/2012 & 1 & Urban & 2 & 3.32 & 2.67 & 0.19 & 0.02 & 0.15 & 6.35 \\
\hline 6/27/2012 & 2 & Urban & 1 & 2.81 & 1.73 & 0.20 & 0.01 & 0.04 & 4.79 \\
\hline 6/27/2012 & 2 & Urban & 2 & 3.36 & 2.67 & 0.28 & 0.00 & 0.11 & 6.41 \\
\hline 6/27/2012 & 3 & Urban & 1 & 4.65 & 0.73 & 0.10 & 0.03 & 0.16 & 5.66 \\
\hline 6/27/2012 & 3 & Urban & 2 & 2.99 & 0.03 & 0.24 & 0.00 & 0.29 & 3.54 \\
\hline 7/13/2012 & 1 & Agriculture & 1 & 4.66 & 0.27 & 0.40 & 0.06 & 0.21 & 5.59 \\
\hline 7/13/2012 & 1 & Agriculture & 2 & 5.18 & 0.03 & 0.14 & 0.00 & 0.12 & 5.46 \\
\hline 7/13/2012 & 2 & Agriculture & 1 & 3.37 & 2.31 & 0.40 & 0.06 & 0.02 & 6.15 \\
\hline 7/13/2012 & 2 & Agriculture & 2 & 3.52 & 3.51 & 0.33 & 0.00 & 0.11 & 7.47 \\
\hline 7/13/2012 & 3 & Agriculture & 1 & 2.91 & 1.30 & 0.32 & 1.23 & 0.33 & 6.09 \\
\hline 7/13/2012 & 3 & Agriculture & 2 & 2.09 & 1.43 & 0.37 & 0.00 & 0.25 & 4.13 \\
\hline 7/13/2012 & 1 & Control & 1 & 2.28 & 0.00 & 0.17 & 0.00 & 0.04 & 2.49 \\
\hline 7/13/2012 & 1 & Control & 2 & 4.29 & 0.48 & 0.21 & 0.02 & 0.19 & 5.18 \\
\hline 7/13/2012 & 2 & Control & 1 & 2.84 & 5.70 & 0.23 & 0.26 & 0.25 & 9.27 \\
\hline 7/13/2012 & 2 & Control & 2 & 4.24 & 0.89 & 0.19 & 0.00 & 0.08 & 5.39 \\
\hline 7/13/2012 & 3 & Control & 1 & 0.57 & 0.09 & 0.05 & 0.00 & 0.07 & 0.78 \\
\hline 7/13/2012 & 3 & Control & 2 & & & & & & \\
\hline 7/13/2012 & 1 & Urban & 1 & & & & & & \\
\hline 7/13/2012 & 1 & Urban & 2 & 3.99 & 6.05 & 0.17 & 1.26 & 0.16 & 11.63 \\
\hline 7/13/2012 & 2 & Urban & 1 & 2.63 & 1.31 & 0.13 & 0.00 & 0.27 & 4.34 \\
\hline 7/13/2012 & 2 & Urban & 2 & 2.30 & 3.59 & 0.18 & 0.00 & 0.12 & 6.19 \\
\hline 7/13/2012 & 3 & Urban & 1 & 2.49 & 0.03 & 0.09 & 0.06 & 0.06 & 2.72 \\
\hline 7/13/2012 & 3 & Urban & 2 & 2.15 & 2.92 & 0.31 & 0.00 & 0.16 & 5.53 \\
\hline 7/26/2012 & 1 & Agriculture & 1 & 4.11 & 0.39 & 0.25 & 0.00 & 0.72 & 5.47 \\
\hline 7/26/2012 & 1 & Agriculture & 2 & 4.86 & 0.00 & 0.36 & 0.06 & 0.56 & 5.84 \\
\hline 7/26/2012 & 2 & Agriculture & 1 & 1.85 & 0.54 & 0.21 & 0.00 & 0.33 & 2.92 \\
\hline 7/26/2012 & 2 & Agriculture & 2 & 3.34 & 0.43 & 0.19 & 0.00 & 0.62 & 4.58 \\
\hline $7 / 26 / 2012$ & 3 & Agriculture & 1 & 3.23 & 0.35 & 0.28 & 0.30 & 0.69 & 4.85 \\
\hline 7/26/2012 & 3 & Agriculture & 2 & 5.31 & 4.05 & 0.15 & 0.00 & 2.51 & 12.02 \\
\hline 7/26/2012 & 1 & Control & 1 & 1.70 & 0.76 & 0.06 & 0.00 & 0.57 & 3.10 \\
\hline 7/26/2012 & 1 & Control & 2 & 5.07 & 1.33 & 0.15 & 0.00 & 0.75 & 7.30 \\
\hline 7/26/2012 & 2 & Control & 1 & 3.63 & 6.30 & 0.05 & 0.10 & 0.97 & 11.06 \\
\hline 7/26/2012 & 2 & Control & 2 & 2.06 & 5.18 & 0.14 & 0.00 & 0.31 & 7.69 \\
\hline 7/26/2012 & 3 & Control & 1 & 2.46 & 2.92 & 0.18 & 0.00 & 0.26 & 5.84 \\
\hline $7 / 26 / 2012$ & 3 & Control & 2 & 4.37 & 1.13 & 0.21 & 0.00 & 0.59 & 6.29 \\
\hline 7/26/2012 & 1 & Urban & 1 & 2.80 & 6.83 & 0.07 & 0.00 & 0.44 & 10.14 \\
\hline 7/26/2012 & 1 & Urban & 2 & 2.64 & 3.42 & 0.07 & 0.00 & 0.68 & 6.81 \\
\hline 7/26/2012 & 2 & Urban & 1 & 1.78 & 6.06 & 0.06 & 0.10 & 0.34 & 8.33 \\
\hline 7/26/2012 & 2 & Urban & 2 & 3.13 & 15.78 & 0.07 & 0.00 & 0.73 & 19.71 \\
\hline
\end{tabular}


Propagules \&

Date Block Treatment Basket Leaves

\begin{tabular}{|c|c|c|c|c|c|c|c|c|c|}
\hline 7/26/2012 & 3 & Urban & 1 & 1.34 & 0.25 & 0.23 & 0.00 & 0.54 & 2.36 \\
\hline 7/26/2012 & 3 & Urban & 2 & 3.52 & 0.03 & 0.03 & 0.00 & 0.67 & 4.25 \\
\hline 8/9/2012 & 1 & Agriculture & 1 & 2.99 & 0.42 & 0.31 & 0.00 & 0.31 & 4.03 \\
\hline 8/9/2012 & 1 & Agriculture & 2 & 3.83 & 0.12 & 0.22 & 0.00 & 0.18 & 4.36 \\
\hline 8/9/2012 & 2 & Agriculture & 1 & 2.09 & 0.33 & 0.28 & 0.73 & 0.10 & 3.53 \\
\hline 8/9/2012 & 2 & Agriculture & 2 & 1.71 & 2.56 & 0.21 & 0.00 & 0.08 & 4.57 \\
\hline 8/9/2012 & 3 & Agriculture & 1 & 2.83 & 1.23 & 0.50 & 0.15 & 0.18 & 4.88 \\
\hline 8/9/2012 & 3 & Agriculture & 2 & 3.87 & 0.74 & 0.50 & 0.15 & 0.75 & 6.00 \\
\hline 8/9/2012 & 1 & Control & 1 & 3.65 & 0.05 & 0.45 & 0.00 & 0.11 & 4.26 \\
\hline 8/9/2012 & 1 & Control & 2 & 3.51 & 1.42 & 0.19 & 0.00 & 0.31 & 5.44 \\
\hline 8/9/2012 & 2 & Control & 1 & 2.57 & 12.50 & 0.24 & 0.00 & 0.55 & 15.85 \\
\hline 8/9/2012 & 2 & Control & 2 & 2.40 & 2.22 & 0.21 & 0.00 & 0.17 & 5.00 \\
\hline 8/9/2012 & 3 & Control & 1 & 0.37 & 0.19 & 0.15 & 0.00 & 0.11 & 0.82 \\
\hline 8/9/2012 & 3 & Control & 2 & 3.29 & 0.74 & 0.11 & 0.00 & 0.15 & 4.29 \\
\hline 8/9/2012 & 1 & Urban & 1 & 2.27 & 0.96 & 0.17 & 0.00 & 0.14 & 3.53 \\
\hline 8/9/2012 & 1 & Urban & 2 & 2.59 & 4.70 & 0.16 & 0.00 & 0.18 & 7.63 \\
\hline 8/9/2012 & 2 & Urban & 1 & 3.12 & 14.24 & 0.16 & 0.37 & 0.55 & 18.44 \\
\hline 8/9/2012 & 2 & Urban & 2 & 1.72 & 12.01 & 0.22 & 0.00 & 0.54 & 14.49 \\
\hline 8/9/2012 & 3 & Urban & 1 & 1.59 & 0.02 & 0.12 & 0.00 & 0.12 & 1.86 \\
\hline 8/9/2012 & 3 & Urban & 2 & 1.31 & 0.23 & 0.15 & 0.43 & 0.22 & 2.33 \\
\hline 8/21/2012 & 1 & Agriculture & 1 & 4.10 & 0.41 & 0.19 & 0.00 & 0.29 & 4.98 \\
\hline 8/21/2012 & 1 & Agriculture & 2 & 4.85 & 0.16 & 0.29 & 0.00 & 0.14 & 5.44 \\
\hline 8/21/2012 & 2 & Agriculture & 1 & 2.21 & 0.11 & 0.22 & 0.00 & 0.11 & 2.65 \\
\hline 8/21/2012 & 2 & Agriculture & 2 & 3.33 & 0.61 & 0.28 & 2.82 & 0.11 & 7.15 \\
\hline 8/21/2012 & 3 & Agriculture & 1 & 2.99 & 0.56 & 0.64 & 0.00 & 0.15 & 4.35 \\
\hline $8 / 21 / 2012$ & 3 & Agriculture & 2 & 2.90 & 1.21 & 0.39 & 0.00 & 0.95 & 5.45 \\
\hline 8/21/2012 & 1 & Control & 1 & 3.27 & 3.63 & 0.40 & 0.00 & 0.04 & 7.33 \\
\hline 8/21/2012 & 1 & Control & 2 & 2.04 & 2.01 & 0.17 & 0.06 & 0.39 & 4.66 \\
\hline 8/21/2012 & 2 & Control & 1 & 2.92 & 9.64 & 0.29 & 0.00 & 0.70 & 13.55 \\
\hline $8 / 21 / 2012$ & 2 & Control & 2 & 2.36 & 0.04 & 0.25 & 0.00 & 0.17 & 2.82 \\
\hline 8/21/2012 & 3 & Control & 1 & 1.36 & 0.10 & 0.20 & 0.00 & 0.12 & 1.79 \\
\hline 8/21/2012 & 3 & Control & 2 & 1.97 & 0.29 & 0.32 & 0.00 & 0.22 & 2.81 \\
\hline $8 / 21 / 2012$ & 1 & Urban & 1 & 1.83 & 0.88 & 0.20 & 0.39 & 0.25 & 3.54 \\
\hline 8/21/2012 & 1 & Urban & 2 & 1.21 & 3.01 & 0.18 & 0.00 & 0.14 & 4.53 \\
\hline 8/21/2012 & 2 & Urban & 1 & 2.31 & 16.92 & 0.19 & 0.00 & 0.35 & 19.77 \\
\hline 8/21/2012 & 2 & Urban & 2 & 2.47 & 19.30 & 0.18 & 0.00 & 0.48 & 22.42 \\
\hline 8/21/2012 & 3 & Urban & 1 & 1.54 & 0.02 & 0.12 & 0.04 & 0.15 & 1.86 \\
\hline 8/21/2012 & 3 & Urban & 2 & 2.07 & 0.31 & 0.50 & 0.00 & 0.12 & 3.01 \\
\hline 9/10/2012 & 1 & Agriculture & 1 & 3.48 & 3.47 & 0.17 & 0.99 & 0.56 & 8.67 \\
\hline 9/10/2012 & 1 & Agriculture & 2 & 3.84 & 0.22 & 0.32 & 0.87 & 0.40 & 5.64 \\
\hline 9/10/2012 & 2 & Agriculture & 1 & 1.50 & 0.35 & 0.28 & 0.12 & 0.40 & 2.66 \\
\hline
\end{tabular}

Total

itterfall

03

53

57

00

26

5.85

82

29

7.63

18.44

86

33

44

.65

35

.45

66

3.55

79

.81

53

9.77

86

01

64

2.66 
Propagules \&

Date Block Treatment Basket Leaves

9/10/2012 3 Agriculture 11.94

9/10/2012 3 Agriculture 232.52

$\begin{array}{rrrrr}9 / 10 / 2012 & 1 & \text { Control } & 1 & 1.74\end{array}$

9/10/2012 1 Control $\quad 2 \quad 2.75$

$\begin{array}{lllll}9 / 10 / 2012 & 2 & \text { Control } & 1 & 2.19\end{array}$

9/10/2012 2 Control $\quad 2 \quad 2.33$

9/10/2012 3 Control $\quad 1 \quad 1.64$

9/10/2012 3 Control $\quad 2 \quad 1.46$

9/10/2012 1 Urban $\quad 1 \quad 2.22$

9/10/2012 1 Urban $\quad 2 \quad 2.46$

9/10/2012 2 Urban $\quad 1 \quad 3.49$

$\begin{array}{lllll}9 / 10 / 2012 & 2 & \text { Urban } & 2 & 2.58\end{array}$

$\begin{array}{lllll}9 / 10 / 2012 & 3 & \text { Urban } & 1 & 1.48\end{array}$

9/10/2012 3 Urban $\quad 2 \quad 2.89$

9/24/2012 1 Agriculture 113.30

9/24/2012 1 Agriculture $2 \quad 1.91$

9/24/2012 2 Agriculture 1101

9/24/2012 2 Agriculture $2 \quad 2.74$

9/24/2012 3 Agriculture 112.62

9/24/2012 3 Agriculture $2 \quad 2.36$

$\begin{array}{lllll}9 / 24 / 2012 & 1 & \text { Control } & 1 & 1.71\end{array}$

9/24/2012 1 Control $\quad 2 \quad 1.65$

9/24/2012 2 Control $\quad 1 \quad 3.53$

$\begin{array}{lllll}9 / 24 / 2012 & 2 & \text { Control } & 2 & 2.44\end{array}$

9/24/2012 3 Control $\quad 1 \quad 1.35$

9/24/2012 3 Control $\quad 2 \quad 1.65$

9/24/2012 1 Urban $\quad 1 \quad 0.79$

9/24/2012 1 Urban $\quad 2 \quad 1.65$

9/24/2012 2 Urban $\quad 11.16$

9/24/2012 2 Urban $\quad 2 \quad 2.11$

$\begin{array}{lllll}9 / 24 / 2012 & 3 & \text { Urban } & 1 & 1.13\end{array}$

9/24/2012 3 Urban $\quad 2 \quad 1.33$

10/8/2012 1 Agriculture 113.03

10/8/2012 1 Agriculture $2 \quad 1.90$

10/8/2012 2 Agriculture $\quad 1 \quad 1.81$

10/8/2012 2 Agriculture $2 \quad 1.19$

10/8/2012 3 Agriculture 1101.49

10/8/2012 3 Agriculture $2 \quad 1.56$

10/8/2012 1 Control $\quad 1 \quad 1.89$

10/8/2012 1 Control $\quad 2 \quad 1.78$
Flowers

0.26

0.41

1.31

0.15

0.60

5.92

0.91

0.13

0.15

10.51

0.04

10.28

11.59

0.11

0.15

0.66

0.07

0.49

0.27

0.32

0.33

0.78

4.44

3.85

0.50

0.07

0.68

0.39

0.06

2.21

1.10

0.00

0.21

6.06

0.21

0.42

0.28

0.65

0.71

3.49

3.00
Stipules Wood Misc

0.29

0.15

0.29

0.27

0.16

0.29

0.28

0.14

0.29

0.25

0.23

0.27

0.19

0.15

0.26

0.24

0.13

0.30

0.36

0.23

0.39

0.32

0.37

0.08

0.21

0.07

0.29

0.26

0.23

0.23

0.40

0.07

0.20

0.25

0.11

0.24

0.16

0.09

0.20

0.07

0.12 $\begin{array}{ll}0.00 & 0.38\end{array}$

$\begin{array}{ll}0.02 & 0.34\end{array}$

$0.00 \quad 0.68$

$\begin{array}{ll}0.00 & 0.29\end{array}$

$0.45 \quad 0.57$

$0.21 \quad 0.63$

$\begin{array}{ll}0.07 & 0.28\end{array}$

$0.00 \quad 0.26$

$1.81 \quad 0.66$

$1.01 \quad 0.34$

$\begin{array}{ll}0.26 & 0.43\end{array}$

$\begin{array}{ll}0.00 & 0.47\end{array}$

$2.92 \quad 0.45$

$0.03 \quad 0.35$

$3.40 \quad 0.41$

$\begin{array}{ll}1.13 & 0.35\end{array}$

$0.00 \quad 0.11$

$0.00 \quad 0.14$

$0.00 \quad 0.11$

$0.00 \quad 0.15$

$0.00 \quad 0.15$

$0.00 \quad 0.10$

$0.62 \quad 0.23$

$\begin{array}{ll}0.00 & 0.02\end{array}$

$0.00 \quad 0.11$

$\begin{array}{ll}0.00 & 0.07\end{array}$

$0.00 \quad 0.19$

$\begin{array}{ll}0.00 & 0.12\end{array}$

$0.00 \quad 0.17$

$0.00 \quad 0.12$

$0.00 \quad 0.11$

$0.56 \quad 0.18$

$0.00 \quad 0.20$

$0.13 \quad 0.54$

$\begin{array}{ll}0.00 & 0.28\end{array}$

$0.00 \quad 0.13$

$\begin{array}{ll}0.00 & 0.21\end{array}$

$\begin{array}{ll}0.00 & 0.23\end{array}$

$0.00 \quad 0.25$

$0.00 \quad 0.16$

$0.22 \quad 0.52$
Total

litterfall

3.04

2.86

4.81

2.45

4.53

9.24

3.87

2.16

4.37

14.33

3.42

14.51

17.73

2.12

7.11

5.67

2.23

1.93

3.49

3.32

3.22

2.92

7.31

7.48

3.26

1.56

2.80

1.55

2.11

3.72

3.73

1.93

1.94

10.02

2.50

2.61

1.84

2.46

2.73

5.62

5.63 
Propagules \&

Date Block Treatment Basket Leaves

10/8/2012 2 Control

10/8/2012 3 Control

10/8/2012 3 Control

10/8/2012 1 Urban

10/8/2012 1 Urban

10/8/2012 2 Urban

10/8/2012 2 Urban

10/8/2012 3 Urban

10/8/2012 3 Urban

10/22/2012 1 Agriculture

10/22/2012 1 Agriculture

10/22/2012 2 Agriculture

10/22/2012 2 Agriculture

10/22/2012 3 Agriculture

10/22/2012 3 Agriculture

10/22/2012 1 Control

10/22/2012 1 Control

10/22/2012 2 Control

10/22/2012 2 Control

10/22/2012 3 Control

10/22/2012 3 Control

10/22/2012 1 Urban

10/22/2012 1 Urban

10/22/2012 2 Urban

10/22/2012 2 Urban

10/22/2012 3 Urban

10/22/2012 3 Urban

11/5/2012 1 Agriculture

11/5/2012 1 Agriculture

11/5/2012 2 Agriculture

11/5/2012 2 Agriculture

11/5/2012 3 Agriculture

11/5/2012 3 Agriculture

11/5/2012 1 Control

11/5/2012 1 Control

11/5/2012 2 Control

11/5/2012 2 Control

11/5/2012 3 Control

11/5/2012 3 Control

Flowers

$\begin{array}{ll}1 & 1.23 \\ 2 & 2.05 \\ 1 & 0.86 \\ 2 & 2.15\end{array}$

$$
0.00
$$

0.09

0.08

0.23

1.84

0.18

4.31

0.63

0.00

0.22

4.78

4.72

0.29

0.24

1.09

1.11

0.31

3.28

0.05

0.09

0.00

0.15

1.44

0.09

0.01

0.05

0.10

0.14

0.76

0.16

0.28

0.12

1.82

0.77

1.77

1.33

0.05

0.32

0.03

0.27

0.30
Stipules Wood Misc

$\begin{array}{lll}0.18 & 0.00 & 0.04\end{array}$

$\begin{array}{lll}0.18 & 0.00 & 0.14\end{array}$

$\begin{array}{lll}0.00 & 0.00 & 0.00\end{array}$

$\begin{array}{lll}0.13 & 0.00 & 0.07\end{array}$

$\begin{array}{lll}0.36 & 0.00 & 0.28\end{array}$

$\begin{array}{lll}0.21 & 0.00 & 0.06\end{array}$

$\begin{array}{lll}0.06 & 0.00 & 0.33\end{array}$

$\begin{array}{lll}0.20 & 0.00 & 0.17\end{array}$

$\begin{array}{lll}0.04 & 0.00 & 0.15\end{array}$

$\begin{array}{lll}0.09 & 0.00 & 0.19\end{array}$

$\begin{array}{lll}0.27 & 0.00 & 0.55\end{array}$

$\begin{array}{lll}0.00 & 0.06 & 0.13\end{array}$

$\begin{array}{lll}0.06 & 0.00 & 0.11\end{array}$

$\begin{array}{lll}0.11 & 0.00 & 0.12\end{array}$

$\begin{array}{lll}0.23 & 0.00 & 0.26\end{array}$

$\begin{array}{lll}0.09 & 0.00 & 0.28\end{array}$

$\begin{array}{lll}0.07 & 0.00 & 0.13\end{array}$

$\begin{array}{lll}0.14 & 0.11 & 0.29\end{array}$

$\begin{array}{lll}0.20 & 0.00 & 0.07\end{array}$

$\begin{array}{lll}0.11 & 0.00 & 0.05\end{array}$

$\begin{array}{lll}0.04 & 0.00 & 0.09\end{array}$

$\begin{array}{lll}0.14 & 0.00 & 0.19\end{array}$

$\begin{array}{lll}0.17 & 0.00 & 0.19\end{array}$

$\begin{array}{lll}0.20 & 0.00 & 0.20\end{array}$

$\begin{array}{lll}0.30 & 0.00 & 0.07\end{array}$

$\begin{array}{lll}0.13 & 0.00 & 0.10\end{array}$

$\begin{array}{lll}0.04 & 0.00 & 0.25\end{array}$

$\begin{array}{lll}0.12 & 0.00 & 0.10\end{array}$

$\begin{array}{lll}0.12 & 0.49 & 0.30\end{array}$

$\begin{array}{lll}0.11 & 0.00 & 0.04\end{array}$

$\begin{array}{lll}0.13 & 0.00 & 0.14\end{array}$

$\begin{array}{lll}0.22 & 0.00 & 0.08\end{array}$

$\begin{array}{lll}0.15 & 0.00 & 0.17\end{array}$

$\begin{array}{lll}0.19 & 3.37 & 0.49\end{array}$

$\begin{array}{lll}0.13 & 0.00 & 0.24\end{array}$

$\begin{array}{lll}0.16 & 0.17 & 0.28\end{array}$

$\begin{array}{lll}0.17 & 0.00 & 0.05\end{array}$

$\begin{array}{lll}0.19 & 0.00 & 0.01\end{array}$

$\begin{array}{lll}0.03 & 0.00 & 0.03\end{array}$

$\begin{array}{lll}0.18 & 0.03 & 0.08\end{array}$

$\begin{array}{lll}0.21 & 0.00 & 0.18\end{array}$
Total

litterfall

1.45

2.45

0.94

2.57

3.97

1.40

6.03

2.69

1.85

2.29

7.23

5.94

2.77

1.11

3.12

3.48

1.87

6.13

1.32

2.74

1.52

2.49

3.84

1.63

1.68

1.13

2.27

1.89

3.91

1.19

1.52

1.42

3.57

7.32

2.94

2.57

2.35

1.83

1.15

1.98

1.52 
Propagules \&

Date Block Treatment Basket Leaves

$\begin{array}{lllll}11 / 5 / 2012 & 2 & \text { Urban } & 2 & 1.71\end{array}$

$\begin{array}{lllll}11 / 5 / 2012 & 3 & \text { Urban } & 1 & 1.86\end{array}$

$\begin{array}{lllll}11 / 5 / 2012 & 3 & \text { Urban } & 2 & 1.47\end{array}$

11/26/2012 1 Agriculture 111.25

11/26/2012 1 Agriculture $\quad 2 \quad 0.68$

11/26/2012 2 Agriculture 1101.34

11/26/2012 2 Agriculture

11/26/2012 3 Agriculture

11/26/2012 3 Agriculture

11/26/2012 11 Control

11/26/2012 2 Control

11/26/2012 2 Control

11/26/2012 3 Control

11/26/2012 3 Control

11/26/2012 1 Urban

11/26/2012 1 Urban

$11 / 26 / 2012 \quad 2$ Urban

$11 / 26 / 2012 \quad 2$ Urban

$11 / 26 / 2012 \quad 3$ Urban

11/26/2012 3 Urban

12/8/2012 1 Agriculture

12/8/2012 1 Agriculture

12/8/2012 2 Agriculture

12/8/2012 2 Agriculture

12/8/2012 3 Agriculture

12/8/2012 3 Agriculture

12/8/2012 1 Control

12/8/2012 1 Control

12/8/2012 2 Control

12/8/2012 2 Control

12/8/2012 3 Control

12/8/2012 3 Control

$12 / 8 / 2012 \quad 1 \quad$ Urban

12/8/2012 1 Urban

$12 / 8 / 2012 \quad 2$ Urban

12/8/2012 2 Urban

12/8/2012 3 Urban

12/8/2012 3 Urban

Flowers

$$
0.36
$$

0.00

0.33

0.11

0.06

2.03

2.81

0.14

0.23

1.78

3.57

0.26

1.62

0.05

0.03

0.00

0.14

0.09

0.20

0.03

0.04

0.02

0.00

0.54

0.24

0.58

1.67

0.51

1.04

0.27

0.41

0.05

0.05

0.03

0.15

0.09

0.05

0.00

0.03

0.05

0.00
Stipules Wood Misc

$\begin{array}{lll}0.13 & 0.00 & 0.09\end{array}$

$\begin{array}{lll}0.06 & 0.00 & 0.03\end{array}$

$\begin{array}{lll}0.14 & 1.01 & 0.14\end{array}$

$\begin{array}{lll}0.00 & 0.00 & 0.31\end{array}$

$\begin{array}{lll}0.19 & 0.00 & 0.04\end{array}$

$\begin{array}{lll}0.17 & 0.12 & 0.21\end{array}$

$\begin{array}{lll}0.14 & 0.00 & 0.02\end{array}$

$\begin{array}{lll}0.28 & 0.00 & 0.14\end{array}$

$\begin{array}{lll}0.19 & 0.00 & 0.04\end{array}$

$\begin{array}{lll}0.21 & 0.00 & 0.13\end{array}$

$\begin{array}{lll}0.37 & 0.00 & 2.22\end{array}$

$\begin{array}{lll}0.25 & 0.00 & 0.03\end{array}$

$\begin{array}{lll}0.24 & 0.00 & 0.18\end{array}$

$\begin{array}{lll}0.24 & 0.00 & 0.06\end{array}$

$\begin{array}{lll}0.14 & 0.12 & 0.06\end{array}$

$\begin{array}{lll}0.16 & 0.00 & 0.00\end{array}$

$\begin{array}{lll}0.18 & 0.00 & 0.22\end{array}$

$\begin{array}{lll}0.16 & 0.00 & 0.16\end{array}$

0.20

0.22

$0.00 \quad 0.11$

$\begin{array}{ll}0.00 & 0.08\end{array}$

$\begin{array}{lll}0.23 & 0.00 & 0.07\end{array}$

0.25

0.05

$0.00 \quad 0.05$

$0.00 \quad 0.08$

$\begin{array}{lll}0.22 & 0.00 & 0.27\end{array}$

$\begin{array}{lll}0.02 & 0.10 & 0.21\end{array}$

$\begin{array}{lll}0.21 & 0.00 & 0.16\end{array}$

$\begin{array}{lll}0.25 & 0.10 & 0.16\end{array}$

0.22

$0.00 \quad 0.15$

0.23

$0.16 \quad 0.19$

$0.52 \quad 0.13$

$0.00 \quad 0.11$

$0.00 \quad 0.12$

0.19

0.14

$0.00 \quad 0.18$

$\begin{array}{lll}0.13 & 0.00 & 0.01\end{array}$

$\begin{array}{lll}0.16 & 0.00 & 0.21\end{array}$

$\begin{array}{lll}0.26 & 0.00 & 0.14\end{array}$

$\begin{array}{lll}0.10 & 0.00 & 0.15\end{array}$

$\begin{array}{lll}0.11 & 0.00 & 0.13\end{array}$

$\begin{array}{lll}0.25 & 0.00 & 0.07\end{array}$

$\begin{array}{lll}0.06 & 0.00 & 0.01\end{array}$

$\begin{array}{lll}0.15 & 0.00 & 0.08\end{array}$
Total

litterfall

1.13

1.33

3.33

2.27

1.76

3.78

3.65

1.90

1.23

3.57

6.68

1.53

3.44

1.30

1.39

1.21

1.54

1.61

1.34

1.33

1.43

1.18

1.03

2.01

1.28

1.73

3.53

2.01

2.65

2.45

1.70

1.47

0.97

0.56

1.81

1.92

1.55

0.73

0.88

0.88

1.51 
Propagules \&

Date Block Treatment Basket Leaves

12/24/2012 1 Agriculture 11.08

12/24/2012 1 Agriculture 20.46

$12 / 24 / 2012 \quad 2 \quad$ Agriculture 110.69

$\begin{array}{lllll}12 / 24 / 2012 & 2 & \text { Agriculture } & 2 & 0.38\end{array}$

12/24/2012 3 Agriculture 1101.36

12/24/2012 3 Agriculture 2

12/24/2012 1 Control

12/24/2012 1 Control

12/24/2012 2 Control

12/24/2012 2 Control 2

12/24/2012 3 Control

12/24/2012 3 Control

12/24/2012 1 Urban

12/24/2012 1 Urban

12/24/2012 2 Urban

12/24/2012 2 Urban

12/24/2012 3 Urban

12/24/2012 3 Urban

1/10/2013 1 Agriculture

1/10/2013 1 Agriculture

1/10/2013 2 Agriculture

1/10/2013 2 Agriculture

1/10/2013 3 Agriculture

1/10/2013 3 Agriculture

1/10/2013 1 Control

1/10/2013 1 Control

1/10/2013 2 Control

1/10/2013 2 Control

1/10/2013 3 Control

1/10/2013 3 Control

1/10/2013 1 Urban

1/10/2013 1 Urban

$1 / 10 / 2013 \quad 2 \quad$ Urban

1/10/2013 2 Urban

$1 / 10 / 2013 \quad 3$ Urban

1/10/2013 3 Urban

1/24/2013 1 Agriculture

1/24/2013 1 Agriculture

$1 / 24 / 2013 \quad 2$ Agriculture

1/24/2013 2 Agriculture

1/24/2013 3 Agriculture
Flowers

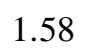

0.02

0.03

0.10

1.62

0.28

0.52

0.89

0.40

1.05

0.84

0.96

1.24

0.61

0.54

0.63

0.52

1.36

0.15

1.23

1.14

0.73

0.47

0.37

0.63

0.84

0.16

1.04

1.17

0.72

0.42

1.22

0.39

1.06

1.70

0.15

0.43

1.18

0.60
0.16

0.17

0.03

0.00

0.08

0.09

0.03

0.23

0.31

0.00

0.00

0.37

0.02

0.04

0.16

0.09

0.32

0.03

0.33

0.00

0.05

0.00

0.05

0.26

0.12

0.00

0.03

0.28

0.00

0.13

0.05

0.34

0.10

0.05
Stipules Wood Misc

$\begin{array}{lll}0.24 & 0.04 & 0.10\end{array}$

$\begin{array}{lll}0.12 & 0.00 & 0.01\end{array}$

$\begin{array}{lll}0.13 & 0.00 & 0.08\end{array}$

$\begin{array}{lll}0.24 & 0.00 & 0.02\end{array}$

$\begin{array}{lll}0.43 & 0.12 & 0.05\end{array}$

$\begin{array}{lll}0.16 & 0.00 & 0.01\end{array}$

$\begin{array}{lll}0.08 & 0.00 & 0.19\end{array}$

$\begin{array}{lll}0.12 & 0.00 & 0.07\end{array}$

$\begin{array}{lll}0.06 & 0.00 & 0.06\end{array}$

$\begin{array}{lll}0.21 & 0.00 & 0.09\end{array}$

$\begin{array}{lll}0.13 & 0.00 & 0.08\end{array}$

$\begin{array}{lll}0.12 & 0.00 & 0.08\end{array}$

$\begin{array}{llll}0.21 & 0.00 & 0.04\end{array}$

0.23

0.05

$\begin{array}{ll}0.00 & 0.03\end{array}$

$0.00 \quad 0.04$

0.03

$\begin{array}{ll}0.00 & 0.04\end{array}$

0.18

0.04

$0.32 \quad 0.14$

$\begin{array}{ll}0.00 & 0.19\end{array}$

0.03

$0.84 \quad 0.16$

$0.34 \quad 0.16$

0.13

$0.00 \quad 0.15$

$\begin{array}{lll}0.12 & 0.00 & 0.99\end{array}$

0.08

0.08

$\begin{array}{ll}0.09 & 0.07\end{array}$

$\begin{array}{ll}0.00 & 0.17\end{array}$

$\begin{array}{lll}0.07 & 0.00 & 0.09\end{array}$

0.09

$\begin{array}{ll}0.56 & 0.06\end{array}$

0.00

0.27

0.15

0.12

0.05

0.14

0.02

$0.00 \quad 0.14$

$0.00 \quad 0.17$

$0.00 \quad 0.18$

$\begin{array}{ll}0.00 & 0.27\end{array}$

$0.00 \quad 0.10$

$3.08 \quad 0.19$

$\begin{array}{ll}0.00 & 0.17\end{array}$

$\begin{array}{lll}0.11 & 0.00 & 0.13\end{array}$

0.11

$\begin{array}{ll}0.00 & 0.09\end{array}$

0.06

$\begin{array}{ll}0.00 & 0.06\end{array}$

$\begin{array}{lll}0.08 & 0.00 & 0.05\end{array}$

0.09

$0.07 \quad 0.15$

0.08
Total

litterfall

3.03

0.60

0.93

0.74

3.57

0.60

0.95

1.11

0.51

1.43

1.14

1.18

1.72

1.19

0.63

0.70

1.53

1.60

1.22

1.95

1.52

2.17

0.74

0.95

0.79

1.60

0.29

1.54

1.76

1.23

0.58

4.67

0.86

1.30

2.03

0.31

0.91

1.60

0.75 
Propagules \&

Total

Date Block Treatment Basket Leaves

Flowers

Stipules Wood Misc

litterfall

\begin{tabular}{|c|c|c|c|c|c|c|c|c|c|}
\hline $1 / 24 / 2013$ & 3 & Agriculture & 2 & 1.59 & 0.15 & 0.05 & 0.00 & 0.10 & 1.90 \\
\hline $1 / 24 / 2013$ & 1 & Control & 1 & 0.69 & 0.15 & 0.02 & 0.00 & 0.03 & 0.89 \\
\hline $1 / 24 / 2013$ & 1 & Control & 2 & 0.94 & 0.00 & 0.09 & 0.00 & 0.11 & 1.14 \\
\hline $1 / 24 / 2013$ & 2 & Control & 1 & 0.65 & 0.03 & 0.01 & 0.00 & 0.19 & 0.88 \\
\hline $1 / 24 / 2013$ & 2 & Control & 2 & 0.89 & 0.00 & 0.06 & 0.00 & 0.05 & 1.00 \\
\hline 1/24/2013 & 3 & Control & 1 & 0.71 & 0.03 & 0.05 & 0.00 & 0.01 & 0.81 \\
\hline $1 / 24 / 2013$ & 3 & Control & 2 & 1.37 & 0.05 & 0.11 & 0.03 & 0.06 & 1.61 \\
\hline $1 / 24 / 2013$ & 1 & Urban & 1 & 0.58 & 0.00 & 0.00 & 0.00 & 0.09 & 0.67 \\
\hline $1 / 24 / 2013$ & 1 & Urban & 2 & 1.37 & 0.03 & 0.04 & 0.00 & 0.02 & 1.47 \\
\hline $1 / 24 / 2013$ & 2 & Urban & 1 & 1.00 & 0.05 & 0.10 & 0.00 & 0.05 & 1.20 \\
\hline $1 / 24 / 2013$ & 2 & Urban & 2 & 0.97 & 0.05 & 0.05 & 0.00 & 0.10 & 1.17 \\
\hline $1 / 24 / 2013$ & 3 & Urban & 1 & 0.52 & 0.00 & 0.00 & 0.00 & 0.03 & 0.55 \\
\hline $1 / 24 / 2013$ & 3 & Urban & 2 & 1.28 & 0.05 & 0.05 & 0.00 & 0.06 & 1.44 \\
\hline 2/8/2013 & 1 & Agriculture & 1 & 1.06 & 0.68 & 0.07 & 0.00 & 0.08 & 1.90 \\
\hline 2/8/2013 & 1 & Agriculture & 2 & 1.07 & 0.00 & 0.00 & 0.00 & 0.05 & 1.12 \\
\hline 2/8/2013 & 2 & Agriculture & 1 & 0.74 & 0.03 & 0.07 & 0.00 & 0.05 & 0.89 \\
\hline 2/8/2013 & 2 & Agriculture & 2 & 0.29 & 0.10 & 0.03 & 0.00 & 0.20 & 0.62 \\
\hline 2/8/2013 & 3 & Agriculture & 1 & 0.85 & 0.29 & 0.16 & 0.00 & 0.14 & 1.44 \\
\hline 2/8/2013 & 3 & Agriculture & 2 & 0.86 & 0.26 & 0.05 & 0.00 & 0.13 & 1.30 \\
\hline 2/8/2013 & 1 & Control & 1 & 0.37 & 0.00 & 0.03 & 0.00 & 0.03 & 0.43 \\
\hline 2/8/2013 & 1 & Control & 2 & 0.83 & 0.08 & 0.07 & 0.06 & 0.14 & 1.18 \\
\hline 2/8/2013 & 2 & Control & 1 & 0.85 & 0.03 & 0.04 & 0.00 & 0.05 & 0.97 \\
\hline 2/8/2013 & 2 & Control & 2 & 0.77 & 0.05 & 0.09 & 0.00 & 0.07 & 0.97 \\
\hline 2/8/2013 & 3 & Control & 1 & 0.34 & 0.00 & 0.03 & 0.00 & 0.01 & 0.38 \\
\hline 2/8/2013 & 3 & Control & 2 & 1.19 & 0.10 & 0.02 & 0.83 & 0.11 & 2.25 \\
\hline 2/8/2013 & 1 & Urban & 1 & 0.38 & 0.11 & 0.04 & 0.09 & 0.17 & 0.78 \\
\hline 2/8/2013 & 1 & Urban & 2 & 1.39 & 0.09 & 0.05 & 0.00 & 0.06 & 1.58 \\
\hline 2/8/2013 & 2 & Urban & 1 & 0.44 & 0.05 & 0.05 & 0.00 & 0.09 & 0.62 \\
\hline 2/8/2013 & 2 & Urban & 2 & 0.42 & 0.05 & 0.02 & 0.00 & 0.14 & 0.62 \\
\hline 2/8/2013 & 3 & Urban & 1 & 0.44 & 0.00 & 0.02 & 0.00 & 0.13 & 0.59 \\
\hline 2/8/2013 & 3 & Urban & 2 & 0.37 & 0.00 & 0.15 & 0.00 & 0.15 & 0.67 \\
\hline 2/22/2013 & 1 & Agriculture & 1 & 1.13 & 0.37 & 0.18 & 0.00 & 0.05 & 1.73 \\
\hline 2/22/2013 & 1 & Agriculture & 2 & 1.15 & 0.00 & 0.15 & 0.00 & 0.11 & 1.41 \\
\hline 2/22/2013 & 2 & Agriculture & 1 & 0.29 & 0.00 & 0.05 & 0.00 & 0.03 & 0.38 \\
\hline 2/22/2013 & 2 & Agriculture & 2 & 1.29 & 0.06 & 0.15 & 0.00 & 0.09 & 1.58 \\
\hline 2/22/2013 & 3 & Agriculture & 1 & 1.22 & 0.05 & 0.04 & 0.00 & 0.07 & 1.38 \\
\hline 2/22/2013 & 3 & Agriculture & 2 & 2.69 & 0.09 & 0.10 & 0.00 & 0.07 & 2.95 \\
\hline 2/22/2013 & 1 & Control & 1 & 0.40 & 0.02 & 0.27 & 0.00 & 0.01 & 0.69 \\
\hline 2/22/2013 & 1 & Control & 2 & 0.51 & 0.15 & 0.15 & 0.06 & 0.07 & 0.94 \\
\hline 2/22/2013 & 2 & Control & 1 & 0.54 & 0.10 & 0.13 & 0.00 & 0.03 & 0.79 \\
\hline 2/22/2013 & 2 & Control & 2 & 0.27 & 0.05 & 0.04 & 0.00 & 0.07 & 0.43 \\
\hline
\end{tabular}


Propagules \&

Date Block Treatment Basket Leaves

2/22/2013 3 Control

2/22/2013 1 Urban

2/22/2013 1 Urban

2/22/2013 2 Urban

2/22/2013 2 Urban

2/22/2013 3 Urban

2/22/2013 3 Urban

3/12/2013 1 Agriculture

3/12/2013 1 Agriculture

3/12/2013 2 Agriculture

3/12/2013 2 Agriculture

3/12/2013 3 Agriculture

3/12/2013 3 Agriculture

3/12/2013 1 Control

3/12/2013 1 Control

3/12/2013 2 Control

3/12/2013 2 Control

3/12/2013 3 Control

3/12/2013 3 Control

3/12/2013 1 Urban

3/12/2013 1 Urban

$3 / 12 / 2013 \quad 2$ Urban

3/12/2013 2 Urban

3/12/2013 3 Urban

3/12/2013 3 Urban

4/1/2013 1 Agriculture

4/1/2013 1 Agriculture

4/1/2013 2 Agriculture

4/1/2013 2 Agriculture

4/1/2013 3 Agriculture

4/1/2013 3 Agriculture

4/1/2013 1 Control

4/1/2013 1 Control

4/1/2013 2 Control

4/1/2013 2 Control

4/1/2013 3 Control

4/1/2013 3 Control

4/1/2013 1 Urban

4/1/2013 1 Urban

4/1/2013 2 Urban

Flowers

$1 \quad 0.73$

$2 \quad 1.20$

$1 \quad 0.95$

$2 \quad 0.43$

$1 \quad 1.05$

$2 \quad 1.35$

$1 \quad 0.61$

$2 \quad 0.84$

$1 \quad 0.41$

$2 \quad 1.40$

$1 \quad 0.67$

20.56

$1 \quad 1.60$

$2 \quad 1.34$

$1 \quad 0.84$

$2 \quad 1.11$

$1 \quad 2.27$

$2 \quad 0.45$

$1 \quad 0.43$

$2 \quad 0.46$

$1 \quad 1.38$

$2 \quad 0.76$

$1 \quad 0.98$

20.43

$1 \quad 0.89$

$2 \quad 0.87$

$1 \quad 1.78$

$2 \quad 0.87$

$1 \quad 0.80$

$2 \quad 0.32$

$1 \quad 2.26$

$2 \quad 2.10$

$1 \quad 1.70$

$2 \quad 1.48$

$1 \quad 0.62$

$2 \quad 0.51$

$1 \quad 0.52$

$2 \quad 1.00$

$1 \quad 1.89$

$2 \quad 1.52$

$1 \quad 0.89$
0.04

0.20

0.09

0.11

0.07

0.14

0.00

0.00

0.32

0.00

0.04

0.03

0.10

0.26

0.03

0.01

0.02

0.00

0.06

0.11

0.02

0.00

0.06

0.03

0.00

0.13

0.24

0.00

0.02

0.21

0.12

0.30

0.00

0.01

0.06

0.01

0.02

0.13

0.00

0.00

0.11
Stipules Wood Misc

$\begin{array}{lll}0.03 & 0.00 & 0.04\end{array}$

$\begin{array}{lll}0.07 & 0.00 & 0.13\end{array}$

$\begin{array}{lll}0.08 & 0.00 & 0.09\end{array}$

$\begin{array}{lll}0.02 & 0.00 & 0.02\end{array}$

$\begin{array}{lll}0.13 & 0.00 & 0.02\end{array}$

$\begin{array}{lll}0.14 & 0.00 & 0.17\end{array}$

$\begin{array}{lll}0.00 & 0.00 & 0.02\end{array}$

$\begin{array}{lll}0.29 & 0.00 & 0.08\end{array}$

$\begin{array}{lll}0.13 & 0.00 & 0.03\end{array}$

$\begin{array}{lll}0.07 & 0.00 & 0.06\end{array}$

$\begin{array}{lll}0.08 & 0.00 & 0.04\end{array}$

$\begin{array}{lll}0.15 & 0.00 & 0.16\end{array}$

$\begin{array}{lll}0.06 & 0.00 & 0.10\end{array}$

$\begin{array}{lll}0.10 & 0.00 & 0.15\end{array}$

$\begin{array}{lll}0.07 & 0.08 & 0.09\end{array}$

$\begin{array}{lll}0.06 & 0.00 & 0.05\end{array}$

$\begin{array}{lll}0.10 & 0.00 & 0.12\end{array}$

$\begin{array}{lll}0.04 & 0.00 & 0.08\end{array}$

$\begin{array}{lll}0.04 & 0.00 & 0.00\end{array}$

$\begin{array}{lll}0.04 & 0.00 & 0.13\end{array}$

$\begin{array}{lll}0.14 & 0.00 & 0.04\end{array}$

$\begin{array}{lll}0.03 & 0.00 & 0.02\end{array}$

$\begin{array}{lll}0.10 & 0.00 & 0.08\end{array}$

$\begin{array}{lll}0.08 & 0.00 & 0.11\end{array}$

$\begin{array}{lll}0.03 & 0.04 & 0.06\end{array}$

$\begin{array}{lll}0.13 & 0.00 & 0.08\end{array}$

$\begin{array}{lll}0.15 & 0.01 & 0.06\end{array}$

0.02

0.10

$\begin{array}{ll}0.17 & 0.04\end{array}$

$\begin{array}{ll}0.18 & 0.07\end{array}$

$\begin{array}{lll}0.10 & 0.00 & 0.08\end{array}$

0.16

0.17

$0.00 \quad 0.08$

$0.00 \quad 0.14$

$\begin{array}{lll}0.12 & 0.00 & 0.07\end{array}$

0.02

0.20

$\begin{array}{ll}0.01 & 0.02\end{array}$

$\begin{array}{ll}0.00 & 0.08\end{array}$

$\begin{array}{lll}0.11 & 0.00 & 0.02\end{array}$

$\begin{array}{lll}0.10 & 0.00 & 0.03\end{array}$

$\begin{array}{lll}0.10 & 0.13 & 0.08\end{array}$

$\begin{array}{lll}0.14 & 0.01 & 0.05\end{array}$

$\begin{array}{lll}0.04 & 0.00 & 0.03\end{array}$

$\begin{array}{lll}0.19 & 0.00 & 0.03\end{array}$
Total

litterfall

0.83

1.59

1.22

0.59

1.27

1.80

0.63

1.22

0.89

1.52

0.83

0.90

1.87

1.85

1.11

1.23

2.51

0.57

0.53

0.75

1.58

0.82

1.21

0.65

1.02

1.21

2.24

1.10

1.17

0.71

2.63

2.70

1.89

1.54

0.95

0.66

0.67

1.43

2.09

1.59

1.22 
Propagules \&

Date Block Treatment Basket Leaves

\begin{tabular}{|c|c|c|c|c|c|c|c|c|c|}
\hline 4/1/2013 & 2 & Urban & 2 & 0.79 & 0.08 & 0.08 & 0.00 & 0.03 & 0.98 \\
\hline 4/1/2013 & 3 & Urban & 1 & 1.90 & 0.00 & 0.05 & 0.00 & 0.01 & 1.96 \\
\hline 4/1/2013 & 3 & Urban & 2 & 0.64 & 0.36 & 0.15 & 0.00 & 0.05 & 1.19 \\
\hline 4/18/2013 & 1 & Agriculture & 1 & 1.96 & 0.05 & 0.11 & 0.00 & 0.09 & 2.21 \\
\hline 4/18/2013 & 1 & Agriculture & 2 & 0.82 & 0.00 & 0.06 & 0.00 & 0.19 & 1.07 \\
\hline 4/18/2013 & 2 & Agriculture & 1 & 1.47 & 0.01 & 0.03 & 0.03 & 0.06 & 1.60 \\
\hline 4/18/2013 & 2 & Agriculture & 2 & 1.67 & 0.00 & 0.03 & 0.00 & 0.18 & 1.88 \\
\hline 4/18/2013 & 3 & Agriculture & 1 & 2.83 & 0.15 & 0.11 & 0.00 & 0.09 & 3.18 \\
\hline 4/18/2013 & 3 & Agriculture & 2 & 1.70 & 0.27 & 0.13 & 0.00 & 0.29 & 2.39 \\
\hline 4/18/2013 & 1 & Control & 1 & 0.89 & 0.00 & 0.01 & 0.00 & 0.02 & 0.92 \\
\hline 4/18/2013 & 1 & Control & 2 & 1.93 & 0.00 & 0.04 & 0.00 & 0.04 & 2.01 \\
\hline 4/18/2013 & 2 & Control & 1 & 1.54 & 0.00 & 0.07 & 0.00 & 0.03 & 1.64 \\
\hline 4/18/2013 & 2 & Control & 2 & 0.85 & 0.00 & 0.06 & 0.00 & 0.10 & 1.01 \\
\hline 4/18/2013 & 3 & Control & 1 & 1.87 & 0.00 & 0.13 & 0.00 & 0.00 & 2.00 \\
\hline 4/18/2013 & 3 & Control & 2 & 1.36 & 0.08 & 0.03 & 0.56 & 0.11 & 2.15 \\
\hline 4/18/2013 & 1 & Urban & 1 & 0.85 & 0.05 & 0.06 & 0.00 & 0.20 & 1.17 \\
\hline 4/18/2013 & 1 & Urban & 2 & 1.27 & 0.12 & 0.02 & 0.01 & 0.08 & 1.49 \\
\hline 4/18/2013 & 2 & Urban & 1 & 0.97 & 0.01 & 0.02 & 0.00 & 0.04 & 1.04 \\
\hline 4/18/2013 & 2 & Urban & 2 & 1.10 & 0.02 & 0.08 & 0.00 & 0.07 & 1.26 \\
\hline 4/18/2013 & 3 & Urban & 1 & 1.80 & 0.00 & 0.02 & 0.00 & 0.05 & 1.87 \\
\hline 4/18/2013 & 3 & Urban & 2 & 1.67 & 0.05 & 0.07 & 0.02 & 0.10 & 1.91 \\
\hline 5/3/2013 & 1 & Agriculture & 1 & 2.10 & 0.02 & 0.27 & 0.00 & 0.08 & 2.47 \\
\hline 5/3/2013 & 1 & Agriculture & 2 & 1.51 & 0.00 & 0.11 & 0.00 & 0.15 & 1.77 \\
\hline 5/3/2013 & 2 & Agriculture & 1 & 1.50 & 0.29 & 0.29 & 0.00 & 0.05 & 2.13 \\
\hline 5/3/2013 & 2 & Agriculture & 2 & 1.52 & 0.00 & 0.30 & 0.00 & 0.22 & 2.05 \\
\hline 5/3/2013 & 3 & Agriculture & 1 & 1.85 & 0.00 & 0.03 & 0.00 & 0.04 & 1.93 \\
\hline 5/3/2013 & 3 & Agriculture & 2 & 1.11 & 0.00 & 0.07 & 0.16 & 0.05 & 1.39 \\
\hline 5/3/2013 & 1 & Control & 1 & 1.30 & 0.02 & 0.03 & 0.00 & 0.05 & 1.40 \\
\hline 5/3/2013 & 1 & Control & 2 & 0.99 & 0.02 & 0.06 & 0.15 & 0.02 & 1.24 \\
\hline 5/3/2013 & 2 & Control & 1 & 2.33 & 0.00 & 0.25 & 0.59 & 0.22 & 3.39 \\
\hline 5/3/2013 & 2 & Control & 2 & 1.38 & 0.00 & 0.11 & 0.34 & 0.15 & 1.99 \\
\hline $5 / 3 / 2013$ & 3 & Control & 1 & 2.61 & 0.00 & 0.13 & 0.00 & 0.01 & 2.74 \\
\hline 5/3/2013 & 3 & Control & 2 & 1.51 & 0.03 & 0.20 & 0.00 & 0.10 & 1.84 \\
\hline 5/3/2013 & 1 & Urban & 1 & 2.10 & 0.02 & 0.07 & 0.00 & 0.11 & 2.30 \\
\hline 5/3/2013 & 1 & Urban & 2 & 1.18 & 1.19 & 0.15 & 0.00 & 0.06 & 2.58 \\
\hline 5/3/2013 & 2 & Urban & 1 & 2.12 & 0.00 & 0.25 & 0.00 & 0.04 & 2.41 \\
\hline 5/3/2013 & 2 & Urban & 2 & 2.03 & 0.02 & 0.39 & 0.00 & 0.04 & 2.48 \\
\hline 5/3/2013 & 3 & Urban & 1 & 2.58 & 0.04 & 0.17 & 0.00 & 0.07 & 2.86 \\
\hline 5/3/2013 & 3 & Urban & 2 & 1.85 & 0.15 & 0.40 & 0.02 & 0.14 & 2.57 \\
\hline 5/30/2013 & 1 & Agriculture & 1 & 1.56 & 0.09 & 0.36 & 0.06 & 0.16 & 2.23 \\
\hline 5/30/2013 & 1 & Agriculture & 2 & 2.99 & 0.00 & 0.31 & 0.05 & 0.47 & 3.82 \\
\hline
\end{tabular}

Total

itterfall

19

07

88

64

00

15

1.04

91

13

93

39

39

84

41

57

82 
Propagules \&

Date Block Treatment Basket Leaves

5/30/2013 2 Agriculture $2 \quad 1.53$

5/30/2013 3 Agriculture 112.76

5/30/2013 3 Agriculture $\quad 2 \quad 0.99$

5/30/2013 1 Control $\quad 1 \quad 2.16$

5/30/2013 1 Control $\quad 2 \quad 3.62$

5/30/2013 2 Control $\quad 1 \quad 1.45$

5/30/2013 2 Control $\quad 2 \quad 1.61$

5/30/2013 3 Control $\quad 1 \quad 1.81$

5/30/2013 3 Control $\quad 2 \quad 2.44$

5/30/2013 1 Urban $\quad 1 \quad 2.43$

5/30/2013 1 Urban $\quad 2 \quad 2.42$

$\begin{array}{lllll}5 / 30 / 2013 & 2 & \text { Urban } & 1 & 1.72\end{array}$

$\begin{array}{lllll}5 / 30 / 2013 & 2 & \text { Urban } & 2 & 1.82\end{array}$

5/30/2013 3 Urban $\quad 1 \quad 3.67$

$\begin{array}{lllll}5 / 30 / 2013 & 3 & \text { Urban } & 2 & 2.07\end{array}$

6/14/2013 1 Agriculture 113.50

6/14/2013 1 Agriculture 22.71

6/14/2013 2 Agriculture 112.30

6/14/2013 2 Agriculture $2 \quad 1.67$

6/14/2013 3 Agriculture 112.84

6/14/2013 3 Agriculture 20.68

6/14/2013 1 Control $\quad 1 \quad 2.50$

6/14/2013 1 Control $\quad 2 \quad 2.55$

$\begin{array}{lllll}6 / 14 / 2013 & 2 & \text { Control } & 1 & 2.12\end{array}$

6/14/2013 2 Control $\quad 2 \quad 2.13$

6/14/2013 3 Control $\quad 1 \quad 1.53$

6/14/2013 3 Control $\quad 2 \quad 2.10$

6/14/2013 1 Urban $\quad 1 \quad 1.81$

$\begin{array}{lllll}6 / 14 / 2013 & 1 & \text { Urban } & 2 & 1.80\end{array}$

6/14/2013 2 Urban $\quad 1 \quad 2.01$

$\begin{array}{lllll}6 / 14 / 2013 & 2 & \text { Urban } & 2 & 2.29\end{array}$

6/14/2013 3 Urban $\quad 1 \quad 3.31$

6/14/2013 3 Urban $\quad 2 \quad 1.84$

6/28/2013 1 Agriculture 112.33

6/28/2013 1 Agriculture $2 \quad 3.61$

6/28/2013 2 Agriculture 112.21

6/28/2013 2 Agriculture $2 \quad 1.83$

6/28/2013 3 Agriculture 112.12

6/28/2013 3 Agriculture $2 \quad 4.01$

6/28/2013 1 Control $\quad 1 \quad 1.03$
Flowers

0.51

1.23

0.04

0.05

0.70

0.60

0.01

0.01

0.00

0.12

0.00

1.58

0.00

0.02

0.00

0.02

0.03

0.02

0.00

0.18

0.97

0.42

1.00

1.16

0.02

0.00

0.00

0.00

0.00

0.03

0.01

0.00

0.00

0.02

0.75

0.00

0.03

0.00

0.23

0.32

1.76
Stipules Wood Misc

$\begin{array}{lll}0.47 & 0.00 & 0.16\end{array}$

$\begin{array}{lll}0.48 & 0.00 & 0.58\end{array}$

$\begin{array}{lll}0.62 & 0.00 & 0.21\end{array}$

$\begin{array}{lll}0.63 & 0.00 & 0.18\end{array}$

$\begin{array}{lll}0.12 & 0.00 & 0.12\end{array}$

$\begin{array}{lll}0.38 & 0.23 & 0.08\end{array}$

$\begin{array}{lll}0.45 & 0.02 & 0.73\end{array}$

$\begin{array}{lll}0.22 & 0.00 & 0.12\end{array}$

$\begin{array}{lll}0.12 & 0.00 & 0.32\end{array}$

0.36

0.56

0.37

0.41

0.33

0.30

0.64

0.35

0.11

0.37

0.33

0.50

0.41

0.40

0.41

0.30

0.26

0.21

0.33

0.18

0.21

0.41

0.37

0.12

0.28

0.23

0.16

0.21

0.27

0.52

0.13

0.35

$0.00 \quad 0.15$

$\begin{array}{ll}0.00 & 0.37\end{array}$

$0.04 \quad 0.09$

$\begin{array}{ll}0.00 & 0.07\end{array}$

$\begin{array}{ll}0.00 & 0.17\end{array}$

$\begin{array}{ll}0.00 & 0.37\end{array}$

$0.19 \quad 0.14$

$\begin{array}{ll}0.00 & 0.23\end{array}$

$0.03 \quad 0.52$

$0.00 \quad 0.18$

$\begin{array}{ll}0.00 & 0.33\end{array}$

$0.00 \quad 0.17$

$0.13 \quad 0.16$

$0.00 \quad 0.26$

$0.05 \quad 0.09$

$0.00 \quad 0.21$

$0.00 \quad 0.13$

$0.00 \quad 0.05$

$\begin{array}{ll}0.00 & 0.07\end{array}$

$\begin{array}{ll}0.00 & 0.32\end{array}$

$0.00 \quad 0.11$

$0.00 \quad 0.06$

$0.00 \quad 0.15$

$0.00 \quad 0.43$

$\begin{array}{ll}0.00 & 0.16\end{array}$

$0.18 \quad 0.17$

$\begin{array}{ll}0.03 & 0.47\end{array}$

$0.00 \quad 0.08$

$0.00 \quad 0.11$

$0.00 \quad 0.15$

$0.04 \quad 0.16$

$0.00 \quad 0.12$

Total

litterfall

3.56

3.82

3.62

1.85

3.11

4.91

2.66

1.97

2.25

3.07

3.36

4.50

2.20

2.34

4.34

3.06

4.11

3.39

2.84

2.52

4.49

1.80

4.15

4.27

2.66

2.52

1.79

2.50

2.30

2.14

2.49

2.81

3.86

2.31

3.66

4.27

2.53

2.21

3.01

4.66

3.26 
Propagules \&

Date Block Treatment Basket Leaves

6/28/2013 1 Control $\quad 2 \quad 2.90$

Flowers

$$
0.61
$$

6/28/2013 2 Control

6/28/2013 2 Control

6/28/2013 3 Control

6/28/2013 3 Control

$\begin{array}{lll}6 / 28 / 2013 & 1 & \text { Urban } \\ 6 / 28 / 2013 & 1 & \text { Urban }\end{array}$

$6 / 28 / 2013 \quad 2$ Urban

6/28/2013 2 Urban

6/28/2013 3 Urban

6/28/2013 3 Urban

7/22/2013 1 Agriculture

$7 / 22 / 2013 \quad 1$ Agriculture

$7 / 22 / 2013 \quad 2$ Agriculture

7/22/2013 2 Agriculture

7/22/2013 3 Agriculture

7/22/2013 3 Agriculture

7/22/2013 1 Control

7/22/2013 1 Control

7/22/2013 2 Control

7/22/2013 2 Control

7/22/2013 3 Control

7/22/2013 3 Control

$7 / 22 / 2013 \quad 1$ Urban

$7 / 22 / 2013 \quad 1 \quad$ Urban

$7 / 22 / 2013 \quad 2$ Urban

$7 / 22 / 2013 \quad 2$ Urban

$7 / 22 / 2013 \quad 3 \quad$ Urban

7/22/2013 3 Urban

7/31/2013 1 Agriculture

$7 / 31 / 2013 \quad 1$ Agriculture

7/31/2013 2 Agriculture

$7 / 31 / 2013 \quad 2$ Agriculture

$7 / 31 / 2013 \quad 3$ Agriculture

7/31/2013 3 Agriculture

7/31/2013 1 Control

7/31/2013 1 Control

7/31/2013 2 Control

7/31/2013 2 Control

7/31/2013 3 Control

$\begin{array}{ll}2 & 2.90 \\ 1 & 2.03 \\ 2 & 2.64 \\ 1 & 1.52\end{array}$

1.57

0.04

0.06

1.41

0.03

0.02

0.00

0.04

0.08

0.21

0.31

0.75

0.42

0.44

0.62

1.66

0.39

0.88

0.06

0.19

1.73

1.08

0.71

0.44

0.37

0.00

0.10

0.30

0.08

0.84

0.20

0.66

1.24

3.76

0.26

0.09

0.12

0.17

0.22
Stipules Wood Misc

$\begin{array}{lll}0.22 & 0.05 & 0.13\end{array}$

$\begin{array}{lll}0.32 & 0.51 & 0.10\end{array}$

$\begin{array}{lll}0.11 & 0.00 & 0.11\end{array}$

$\begin{array}{lll}0.15 & 0.08 & 0.20\end{array}$

$\begin{array}{lll}0.17 & 1.34 & 0.06\end{array}$

$\begin{array}{lll}0.22 & 0.00 & 0.18\end{array}$

$\begin{array}{lll}0.35 & 0.00 & 0.15\end{array}$

$\begin{array}{lll}0.21 & 0.00 & 0.06\end{array}$

$\begin{array}{lll}0.35 & 0.00 & 0.08\end{array}$

$\begin{array}{lll}0.28 & 0.00 & 0.20\end{array}$

$\begin{array}{lll}0.18 & 0.00 & 0.24\end{array}$

$\begin{array}{lll}0.11 & 0.00 & 0.54\end{array}$

$\begin{array}{lll}0.28 & 0.00 & 0.21\end{array}$

$\begin{array}{lll}0.30 & 0.00 & 0.68\end{array}$

0.28

$\begin{array}{ll}1.24 & 0.36\end{array}$

$\begin{array}{lll}0.31 & 0.38 & 0.52\end{array}$

$\begin{array}{lll}0.11 & 1.01 & 0.12\end{array}$

0.15

0.27

$0.23 \quad 0.26$

$0.32 \quad 0.21$

$\begin{array}{llll}0.24 & 0.09 & 0.23\end{array}$

$\begin{array}{lll}0.22 & 0.00 & 0.11\end{array}$

$\begin{array}{llll}0.23 & 0.00 & 0.21\end{array}$

$\begin{array}{lll}0.28 & 0.17 & 0.24\end{array}$

0.24

0.41

$\begin{array}{ll}0.00 & 0.23\end{array}$

$\begin{array}{ll}0.27 & 0.17\end{array}$

$\begin{array}{lll}0.54 & 0.00 & 0.25\end{array}$

0.10

0.28

$\begin{array}{ll}0.00 & 0.23\end{array}$

$0.01 \quad 0.29$

$\begin{array}{lll}0.22 & 0.25 & 0.46\end{array}$

$\begin{array}{llll}0.08 & 10.04 & 1.43\end{array}$

$\begin{array}{llll}0.36 & 0.00 & 0.29\end{array}$

$\begin{array}{lll}0.24 & 0.00 & 0.46\end{array}$

$\begin{array}{lll}0.39 & 0.81 & 0.77\end{array}$

$\begin{array}{llll}0.37 & 0.00 & 0.69\end{array}$

$\begin{array}{lll}0.07 & 0.00 & 0.20\end{array}$

$\begin{array}{lll}0.12 & 0.00 & 0.23\end{array}$

$\begin{array}{llll}0.23 & 3.04 & 0.36\end{array}$

$\begin{array}{lll}0.20 & 3.75 & 0.27\end{array}$

$\begin{array}{llll}0.16 & 0.00 & 0.06\end{array}$

$\begin{array}{llll}0.08 & 0.00 & 0.31\end{array}$
Total

litterfall

3.90

4.52

2.90

2.01

5.31

3.52

3.77

1.94

2.55

2.79

5.11

6.54

5.53

6.46

5.91

6.45

5.91

6.11

4.84

4.56

2.90

5.55

5.82

4.70

4.48

5.21

5.62

4.73

5.12

17.04

4.16

3.68

8.17

5.40

6.00

3.47

5.37

6.28

2.20

4.51 
Propagules \&

Date Block Treatment Basket Leaves

$\begin{array}{lllll}7 / 31 / 2013 & 1 & \text { Urban } & 2 & 3.34\end{array}$

$\begin{array}{lllll}7 / 31 / 2013 & 2 & \text { Urban } & 1 & 3.28\end{array}$

$\begin{array}{lllll}7 / 31 / 2013 & 2 & \text { Urban } & 2 & 4.12\end{array}$

$\begin{array}{lllll}7 / 31 / 2013 & 3 & \text { Urban } & 1 & 5.24\end{array}$

7/31/2013 3 Urban $\quad 2 \quad 3.80$

8/14/2013 1 Agriculture 112.80

8/14/2013 1 Agriculture $2 \quad 5.54$

8/14/2013 2 Agriculture 11.47

8/14/2013 2 Agriculture 223.20

8/14/2013 3 Agriculture 115.05

8/14/2013 3 Agriculture 22.97

8/14/2013 1 Control $\quad 1 \quad 2.64$

8/14/2013 1 Control $\quad 2 \quad 2.43$

8/14/2013 2 Control $\quad 1 \quad 2.69$

$\begin{array}{lllll}8 / 14 / 2013 & 2 & \text { Control } & 2 & 1.71\end{array}$

8/14/2013 3 Control $\quad 1 \quad 2.11$

8/14/2013 3 Control $\quad 2 \quad 7.85$

8/14/2013 1 Urban $\quad 114$

8/14/2013 1 Urban $\quad 2 \quad 2.33$

8/14/2013 2 Urban $\quad 1 \quad 3.30$

8/14/2013 2 Urban $\quad 2 \quad 2.62$

8/14/2013 3 Urban $\quad 1 \quad 2.81$

$\begin{array}{lllll}8 / 14 / 2013 & 3 & \text { Urban } & 2 & 2.45\end{array}$

8/30/2013 1 Agriculture 112.78

8/30/2013 1 Agriculture $2 \quad 3.90$

8/30/2013 2 Agriculture 112.74

8/30/2013 2 Agriculture $2 \quad 2.52$

8/30/2013 3 Agriculture 112.81

8/30/2013 3 Agriculture $\quad 2 \quad 2.69$

8/30/2013 1 Control $\quad 1 \quad 2.11$

8/30/2013 1 Control $\quad 2 \quad 2.38$

8/30/2013 2 Control $\quad 1 \quad 2.22$

$\begin{array}{lllll}8 / 30 / 2013 & 2 & \text { Control } & 2 & 0.67\end{array}$

8/30/2013 3 Control $\quad 1 \quad 1.25$

8/30/2013 3 Control $\quad 2 \quad 1.63$

8/30/2013 1 Urban $\quad 1 \quad 1.81$

$\begin{array}{lllll}8 / 30 / 2013 & 1 & \text { Urban } & 2 & 2.45\end{array}$

$\begin{array}{lllll}8 / 30 / 2013 & 2 & \text { Urban } & 1 & 0.77\end{array}$

$\begin{array}{lllll}8 / 30 / 2013 & 2 & \text { Urban } & 2 & 2.55\end{array}$

8/30/2013 3 Urban $\quad 1 \quad 3.15$
Flowers

0.15

0.07

0.08

0.06

0.03

0.12

8.20

0.07

1.96

0.35

0.61

0.99

0.03

0.25

0.14

0.24

0.05

0.84

0.29

0.32

0.25

0.25

0.02

0.31

0.63

0.11

1.35

0.64

0.86

2.03

0.52

2.07

0.20

0.21

0.15

0.29

0.33

0.43

0.35

0.29

0.13
Stipules Wood Misc

$\begin{array}{lll}0.13 & 0.60 & 0.48\end{array}$

$\begin{array}{lll}0.19 & 0.00 & 0.10\end{array}$

$\begin{array}{lll}0.23 & 0.00 & 0.12\end{array}$

$\begin{array}{lll}0.25 & 0.00 & 0.19\end{array}$

$\begin{array}{lll}0.12 & 0.08 & 0.13\end{array}$

$\begin{array}{lll}0.10 & 0.00 & 0.25\end{array}$

$\begin{array}{lll}0.26 & 0.39 & 0.40\end{array}$

$\begin{array}{lll}0.23 & 0.16 & 0.40\end{array}$

$\begin{array}{lll}0.29 & 0.00 & 0.21\end{array}$

$\begin{array}{llll}0.29 & 0.00 & 0.45\end{array}$

$\begin{array}{lll}0.37 & 0.00 & 0.42\end{array}$

$\begin{array}{lll}0.18 & 0.00 & 0.67\end{array}$

$\begin{array}{lll}0.17 & 0.06 & 0.09\end{array}$

$\begin{array}{lll}0.17 & 0.05 & 0.35\end{array}$

$\begin{array}{lll}0.29 & 0.00 & 0.15\end{array}$

$\begin{array}{lll}0.33 & 0.00 & 0.25\end{array}$

$\begin{array}{lll}0.13 & 0.00 & 0.06\end{array}$

$\begin{array}{lll}0.33 & 0.03 & 0.32\end{array}$

0.28

0.20

0.50

0.63

0.13

0.16

0.11

0.15

0.26

0.25

0.25

0.28

0.11

0.20

$\begin{array}{ll}2.01 & 0.57\end{array}$

$0.15 \quad 0.42$

$0.00 \quad 0.20$

$\begin{array}{ll}0.04 & 0.32\end{array}$

$0.00 \quad 0.32$

$0.00 \quad 0.39$

$\begin{array}{ll}0.07 & 0.25\end{array}$

$0.08 \quad 0.14$

$\begin{array}{ll}0.00 & 0.22\end{array}$

$0.00 \quad 0.42$

$0.00 \quad 0.40$

$0.00 \quad 0.54$

$0.00 \quad 0.11$

$0.00 \quad 0.21$

$0.00 \quad 0.20$

$0.22 \quad 0.18$

$0.00 \quad 0.13$

$0.00 \quad 0.18$

$0.00 \quad 0.31$

$0.04 \quad 0.26$

$0.03 \quad 0.16$ $\begin{array}{llll}0.25 & 0.00 & 0.17 & 3.26\end{array}$

$\begin{array}{llll}0.10 & 0.00 & 0.10 & 3.47\end{array}$

Total

litterfall

3.91

3.69

3.72

4.61

5.59

4.27

12.06

6.40

3.93

4.29

6.45

4.81

2.99

3.24

3.26

2.53

2.35

9.37

4.90

3.42

4.25

3.85

3.28

3.31

3.84

4.38

4.56

3.82

4.30

5.53

2.85

4.86

3.02

1.51

1.66

2.36

2.73

3.25

1.55 
Date Block Treatment Basket Leaves

9/13/2013 1 Agriculture $\quad \begin{array}{lll}1 & 2.97\end{array}$

9/13/2013 1 Agriculture $2 \quad 3.61$

9/13/2013 2 Agriculture 11.92

9/13/2013 2 Agriculture $2 \quad 2.22$

9/13/2013 3 Agriculture 112.83

9/13/2013 3 Agriculture 23.52

9/13/2013 1 Control $\quad 1 \quad 2.82$

9/13/2013 1 Control $\quad 2 \quad 3.23$

9/13/2013 2 Control $\quad 1 \quad 1.53$

$\begin{array}{lllll}9 / 13 / 2013 & 2 & \text { Control } & 2 & 0.97\end{array}$

9/13/2013 3 Control $\quad 1 \quad 1.49$

9/13/2013 3 Control $\quad 2 \quad 2.23$

9/13/2013 1 Urban $\quad 1 \quad 2.40$

9/13/2013 1 Urban $\quad 2 \quad 0.93$

$\begin{array}{lllll}9 / 13 / 2013 & 2 & \text { Urban } & 1 & 3.49\end{array}$

$\begin{array}{lllll}9 / 13 / 2013 & 2 & \text { Urban } & 2 & 0.91\end{array}$

$\begin{array}{lllll}9 / 13 / 2013 & 3 & \text { Urban } & 1 & 1.75\end{array}$

9/13/2013 3 Urban $\quad 2 \quad 2.19$

9/27/2013 1 Agriculture 113.35

9/27/2013 1 Agriculture $2 \quad 3.87$

9/27/2013 2 Agriculture $\quad 1 \quad 1.41$

9/27/2013 2 Agriculture 22.41

9/27/2013 3 Agriculture 1

9/27/2013 3 Agriculture

9/27/2013 1 Control

9/27/2013 1 Control

9/27/2013 2 Control

9/27/2013 2 Control

9/27/2013 3 Control

9/27/2013 3 Control

9/27/2013 1 Urban

9/27/2013 1 Urban

9/27/2013 2 Urban

9/27/2013 2 Urban

9/27/2013 3 Urban

Propagules \&

Flowers Stipules Wood Misc

0.61

1.53

2.74

1.16

0.80

2.97

1.42

4.72

2.65

1.95

0.25

0.09

0.29

0.65

0.74

0.83

3.32

1.73

1.69

5.04

1.82

0.39

0.49

0.13

$\begin{array}{ll}0.06 & 0.18\end{array}$

$\begin{array}{lll}0.19 & 3.56 & 0.43\end{array}$

$\begin{array}{lll}0.13 & 0.71 & 1.24\end{array}$

$\begin{array}{lll}0.33 & 0.00 & 0.32\end{array}$

$\begin{array}{lll}0.19 & 0.03 & 0.85\end{array}$

$\begin{array}{lll}0.17 & 0.00 & 0.62\end{array}$

$\begin{array}{llll}0.25 & 0.21 & 0.59\end{array}$

$\begin{array}{lll}0.09 & 0.02 & 0.38\end{array}$

$\begin{array}{lll}0.10 & 0.00 & 0.27\end{array}$

$\begin{array}{lll}0.12 & 0.00 & 0.75\end{array}$

$\begin{array}{lll}0.19 & 0.00 & 0.44\end{array}$

$\begin{array}{lll}0.13 & 0.00 & 0.05\end{array}$

0.21

$0.00 \quad 0.34$

$\begin{array}{lll}0.06 & 0.00 & 0.24\end{array}$

$\begin{array}{llll}0.08 & 0.00 & 0.39\end{array}$

$\begin{array}{llll}0.23 & 0.00 & 0.29\end{array}$

$\begin{array}{lll}0.31 & 0.00 & 0.42\end{array}$

$\begin{array}{lll}0.17 & 0.00 & 0.25\end{array}$

$\begin{array}{lll}0.17 & 0.00 & 0.37\end{array}$

$\begin{array}{lll}0.37 & 0.00 & 0.25\end{array}$

$\begin{array}{lll}0.18 & 0.00 & 0.29\end{array}$

0.36

$0.00 \quad 0.33$

$\begin{array}{lll}0.33 & 0.00 & 0.37\end{array}$

Total

litterfall

2.54

8.68

8.43

3.73

4.09

6.59

5.99

8.03

6.24

4.35

1.85

1.77

3.06

3.35

2.14

4.83

4.96

3.89

4.43

9.02

6.16

2.49

3.60

1.50

0.33

$\begin{array}{ll}0.00 & 0.33\end{array}$

5.08

3.64

2.79

0.17

$0.10 \quad 0.25$

6.70

0.06

$\begin{array}{ll}0.00 & 0.31\end{array}$

6.61

2.66

0.40

0.53

$0.00 \quad 0.58$

5.75

0.20

$0.00 \quad 0.41$

2.87

0.08

$\begin{array}{lll}0.02 & 0.00 & 0.13\end{array}$

1.55

0.14

$\begin{array}{ll}0.00 & 0.28\end{array}$

2.77

$\begin{array}{lll}0.21 & 0.00 & 0.41\end{array}$

6.65

4.59

0.12

$0.00 \quad 0.45$

5.96

0.2

$0.00 \quad 0.45$

4.36

$\begin{array}{lll}0.42 & 0.00 & 0.58\end{array}$

6.41

$\begin{array}{lll}0.02 & 0.00 & 0.23\end{array}$

4.03

$\begin{array}{lll}0.14 & 0.00 & 0.33\end{array}$

4.77 


\section{Appendix C: Stable isotope data}

Collection of ecosystem components and stable isotope measurements are described in Chapter 3. 


$\begin{array}{cccccccc}\text { Sample type } & \text { Block } & \text { Treatment } & \text { Tree ID } & \text { Date } & \text { d15N } & \text { Molar C:N } & \text { d13C } \\ \text { Green leaves } & 1 & \text { Ambient } & 56 & 8 / 30 / 2013 & 7.16 & 57.3 & -30.07 \\ \text { Green leaves } & 1 & \text { Ambient } & 58 & 8 / 30 / 2013 & 62.32 & 56.8 & -31.18 \\ \text { Green leaves } & 2 & \text { Ambient } & 28 & 8 / 30 / 2013 & 549.96 & 49.7 & -31.01 \\ \text { Green leaves } & 3 & \text { Ambient } & 3 & 8 / 30 / 2013 & 1106.33 & 54.6 & -28.39 \\ \text { Green leaves } & 3 & \text { Ambient } & 6 & 8 / 30 / 2013 & 1296.07 & 66.1 & -30.20 \\ \text { Green leaves } & 3 & \text { Ambient } & 9 & 8 / 30 / 2013 & 21.15 & 68.5 & -30.19 \\ \text { Green leaves } & 1 & \text { Ambient } & 56 & 10 / 13 / 2013 & 26.12 & 56.6 & -29.78 \\ \text { Green leaves } & 1 & \text { Ambient } & 58 & 10 / 13 / 2013 & 18.62 & 66.7 & -29.68 \\ \text { Green leaves } & 1 & \text { Ambient } & 59 & 10 / 13 / 2013 & 31.39 & 57.2 & -29.11 \\ \text { Green leaves } & 1 & \text { Ambient } & 60 & 10 / 13 / 2013 & 20.65 & 43.9 & -31.76 \\ \text { Green leaves } & 1 & \text { Ambient } & 62 & 10 / 13 / 2013 & 3.72 & 57.4 & -29.86 \\ \text { Green leaves } & 2 & \text { Ambient } & 38 & 10 / 13 / 2013 & 11.15 & 62.1 & -31.31 \\ \text { Green leaves } & 2 & \text { Ambient } & 39 & 10 / 13 / 2013 & 3.74 & 67.8 & -30.14 \\ \text { Green leaves } & 2 & \text { Ambient } & 40 & 10 / 13 / 2013 & 6.85 & 68.1 & -32.33 \\ \text { Green leaves } & 3 & \text { Ambient } & 3 & 10 / 13 / 2013 & 101.94 & 57.6 & -29.33 \\ \text { Green leaves } & 3 & \text { Ambient } & 5 & 10 / 13 / 2013 & 87.46 & 60.0 & -30.82 \\ \text { Green leaves } & 3 & \text { Ambient } & 6 & 10 / 13 / 2013 & 37.27 & 64.7 & -30.74 \\ \text { Green leaves } & 3 & \text { Ambient } & 7 & 10 / 13 / 2013 & 17.19 & 77.5 & -30.13 \\ \text { Green leaves } & 3 & \text { Ambient } & 8 & 10 / 13 / 2013 & 393.75 & 99.0 & -30.57 \\ \text { Green leaves } & 3 & \text { Ambient } & 9 & 10 / 13 / 2013 & 11.25 & 67.6 & -31.07 \\ \text { Green leaves } & 1 & \text { Ambient } & 56 & 5 / 22 / 2014 & 208.72 & 54.1 & -30.55 \\ \text { Green leaves } & 1 & \text { Ambient } & 58 & 5 / 22 / 2014 & 180.33 & 55.4 & -30.57 \\ \text { Green leaves } & 1 & \text { Ambient } & 62 & 5 / 22 / 2014 & 18.40 & 56.0 & -29.26 \\ \text { Green leaves } & 2 & \text { Ambient } & 38 & 5 / 22 / 2014 & 173.96 & 53.6 & -30.81 \\ \text { Green leaves } & 3 & \text { Ambient } & 5 & 5 / 22 / 2014 & 392.23 & 61.1 & -30.91 \\ \text { Green leaves } & 3 & \text { Ambient } & 6 & 5 / 22 / 2014 & 1152.14 & 58.2 & -31.94 \\ \text { Green leaves } & 3 & \text { Ambient } & 7 & 5 / 22 / 2014 & 407.50 & 62.2 & -30.75 \\ \text { Green leaves } & 3 & \text { Ambient } & 10 & 5 / 22 / 2014 & 160.45 & 51.7 & -32.05\end{array}$




\begin{tabular}{|c|c|c|c|c|c|c|c|}
\hline Sample type & Block & Treatment & ID & Date & $\mathrm{d} 15 \mathrm{~N}$ & Molar C:N & $\mathrm{d} 13 \mathrm{C}$ \\
\hline Green leaves & 1 & Fertilized & 65 & 8/30/2013 & 3628.10 & 43.7 & -31.21 \\
\hline Green leaves & 1 & Fertilized & 75 & 8/30/2013 & 54.47 & 51.6 & -29.15 \\
\hline reen leaves & 2 & Fertilized & 30 & 8/30/2013 & 931.86 & 50.6 & -28.00 \\
\hline Green leaves & 2 & Fertilized & 33 & 8/30/2013 & 10.44 & 50.4 & -30.40 \\
\hline Green leaves & 2 & Fertilized & 36 & 8/30/2013 & 355.55 & 52.0 & -31.62 \\
\hline reen leaves & 3 & Fertilized & 21 & 8/30/2013 & 19.73 & 50.7 & -31.0 \\
\hline reen leaves & 3 & Fertilized & 22 & 8/30/2013 & 69.15 & 57.7 & -30.8 \\
\hline Green leaves & 3 & Fertilized & 86 & 8/30/2013 & 259.83 & 60.2 & -30.0 \\
\hline Green leaves & 1 & Fertilized & 63 & 10/13/2013 & 686.40 & 46.8 & -28.8 \\
\hline Green leaves & 1 & Fertilized & 65 & 10/13/2013 & 2337.56 & 40.8 & -31.3 \\
\hline leaves & 1 & Fertilized & 66 & 10/13/2013 & 40.28 & 46.8 & -31.2 \\
\hline Green leaves & 1 & Fertilized & 67 & 10/13/2013 & 2221.77 & 44.3 & -29.0 \\
\hline leaves & 1 & Fertilized & 69 & 10/13/2013 & 302.10 & 43.5 & -29.8 \\
\hline aves & 1 & Fertilized & 75 & $10 / 13 / 2013$ & 12.80 & 58.7 & -30.60 \\
\hline aves & 2 & Ferti & 31 & 10/13/2013 & 8.54 & 60.7 & -29.8 \\
\hline leaves & 2 & Ferti & 32 & 10/13/2013 & 514.74 & 53.6 & -28.1 \\
\hline Gree & 2 & Fertilized & 33 & 10/13/2013 & 10.04 & 63.0 & -29.80 \\
\hline Green leaves & 2 & Fertilized & 36 & 10/13/2013 & 215.44 & 54.3 & -31.4 \\
\hline aves & 2 & Fertilized & 36 & 10/13/2013 & 234.83 & 53.5 & -31.6 \\
\hline Green leaves & 3 & Fertilized & 19 & 10/13/2013 & 692.01 & 89.7 & -30.3 \\
\hline Gree & 3 & & 20 & $10 / 13 / 2013$ & 29.96 & 75.7 & -30.1 \\
\hline Green leaves & 3 & Fertilized & 21 & 10/13/2013 & 1680.00 & 89.4 & -29.9 \\
\hline Green leaves & 3 & Fertilized & 22 & 10/13/2013 & 146.29 & 57.1 & -30.4 \\
\hline Green leaves & 3 & Fertilized & 24 & 10/13/2013 & 418.40 & 55.5 & -30.3 \\
\hline Gree & 3 & Fertilized & 26 & 10/13/2013 & 147.39 & 46.7 & -32.2 \\
\hline Green leaves & 1 & Fertilized & 65 & $5 / 22 / 2014$ & 1039.08 & 41.9 & -31.8 \\
\hline Green leaves & 1 & Fertilized & 66 & $5 / 22 / 2014$ & 549.75 & 42.8 & -30.2 \\
\hline Green leaves & 1 & Fertilized & 68 & $5 / 22 / 2014$ & 816.91 & 45.0 & -30.6 \\
\hline leaves & 2 & Fertilized & 33 & $5 / 22 / 2014$ & 160.51 & 56.5 & -31.3 \\
\hline Green leaves & 2 & Fertilized & 36 & $5 / 22 / 2014$ & 1435.36 & 45.5 & -31.8 \\
\hline Green leaves & 3 & Fertilized & 19 & $5 / 22 / 2014$ & 2378.06 & 69.4 & -30.8 \\
\hline Green leaves & 3 & Fertilized & 20 & $5 / 22 / 2014$ & 170.24 & 66.2 & -29.8 \\
\hline Green leaves & 3 & Fertilized & 21 & $5 / 22 / 2014$ & 7244.92 & 64.6 & -31.1 \\
\hline Green leaves & 3 & Fertilized & 22 & $5 / 22 / 2014$ & 1146.88 & 50.1 & -31.0 \\
\hline Green leaves & 3 & Fertilized & 23 & $5 / 22 / 2014$ & 2028.45 & 54.0 & -29.4 \\
\hline Green leaves & 3 & Fertilized & 26 & $5 / 22 / 2014$ & 554.99 & 52.3 & -31.4 \\
\hline Green leaves & 3 & Fertilized & 27 & $5 / 22 / 2014$ & 1949.02 & 64.6 & -29.9 \\
\hline Green leaves & 3 & Fertilized & 86 & 5/22/2014 & 1940.45 & 63.6 & -30.0 \\
\hline
\end{tabular}




\begin{tabular}{lcccccccc}
\multicolumn{1}{c}{ Sample type } & Block & Treatment & ID & Date & d15N & d13C & Molar C:N & mass \\
& & & & & & & & \\
Litter & 1 & Ambient & 153 & $8 / 7 / 2013$ & 4294.83 & -29.10 & 135.9 & 1.54 \\
Litter & 2 & Ambient & 33 & $8 / 7 / 2013$ & 1106.58 & -28.87 & 107.0 & 2.20 \\
Litter & 3 & Ambient & 130 & $8 / 7 / 2013$ & 14155.76 & -29.26 & 136.9 & 1.58 \\
Litter & 1 & Ambient & 98 & $8 / 30 / 2013$ & 11347.63 & -28.22 & 86.6 & 2.54 \\
Litter & 2 & Ambient & 176 & $8 / 30 / 2013$ & 1020.82 & -28.89 & 92.3 & 2.68 \\
Litter & 3 & Ambient & 93 & $8 / 30 / 2013$ & 2386.35 & -28.99 & 85.1 & 2.57 \\
Litter & 1 & Ambient & 189 & $9 / 27 / 2013$ & 7000.52 & -28.88 & 84.3 & 3.13 \\
Litter & 2 & Ambient & 24 & $9 / 27 / 2013$ & 943.61 & -29.14 & 60.0 & 4.21 \\
Litter & 3 & Ambient & 43 & $9 / 27 / 2013$ & 2951.14 & -29.51 & 73.4 & 3.31 \\
Litter & 1 & Ambient & 124 & $10 / 27 / 2013$ & 5794.11 & -28.80 & 65.7 & 3.92 \\
Litter & 2 & Ambient & 1 & $10 / 27 / 2013$ & 1032.91 & -28.84 & 72.7 & 3.75 \\
Litter & 3 & Ambient & 164 & $10 / 27 / 2013$ & 5211.55 & -29.78 & 53.8 & 3.99 \\
Litter & 1 & Fertilized & 94 & $8 / 7 / 2013$ & 6122.27 & -29.74 & 113.3 & 1.91 \\
Litter & 2 & Fertilized & 41 & $8 / 7 / 2013$ & 18997.70 & -29.49 & 111.9 & 2.00 \\
Litter & 3 & Fertilized & 125 & $8 / 7 / 2013$ & 16777.32 & -29.41 & 128.2 & 2.02 \\
Litter & 1 & Fertilized & 131 & $8 / 30 / 2013$ & 9590.68 & -29.27 & 58.1 & 3.46 \\
Litter & 2 & Fertilized & 187 & $8 / 30 / 2013$ & 12688.53 & -29.78 & 71.2 & 3.32 \\
Litter & 3 & Fertilized & 178 & $8 / 30 / 2013$ & 11183.18 & -29.19 & 92.4 & 2.91 \\
Litter & 1 & Fertilized & 101 & $9 / 27 / 2013$ & 5188.09 & -29.36 & 58.4 & 3.99 \\
Litter & 1 & Fertilized & 156 & $10 / 27 / 2013$ & 5764.79 & -29.69 & 55.6 & 4.32 \\
Litter & 2 & Fertilized & 196 & $10 / 27 / 2013$ & 3276.97 & -28.19 & 51.8 & 5.08 \\
Litter & 3 & Fertilized & 136 & $10 / 27 / 2013$ & 4170.64 & -28.82 & 49.7 & 3.44
\end{tabular}




\begin{tabular}{|c|c|c|c|c|c|c|c|}
\hline Sample type & Block & Treatment & ID & Date & $\mathrm{d} 15 \mathrm{~N}$ & d13C & Molar C:I \\
\hline Fine roots & 1 & Ambient & 118 & 5/22/2014 & 262.77 & -26.99 & 76.4 \\
\hline Fine roots & 1 & Ambient & 138 & 5/22/2014 & 554.21 & -26.53 & 78.5 \\
\hline Fine roots & 2 & Ambient & 142 & 5/22/2014 & 359.12 & -27.70 & 67.5 \\
\hline Fine roots & 1 & Fertilized & 147 & $5 / 22 / 2014$ & 611.24 & -27.58 & 62.1 \\
\hline Fine roots & 1 & Fertilized & 135 & 5/22/2014 & 1473.95 & -26.59 & 86.5 \\
\hline Fine roots & 2 & Fertilized & 133 & 5/22/2014 & 1988.60 & -27.88 & 80.1 \\
\hline Fine roots & 3 & Fertilized & 154 & 5/22/2014 & 3128.24 & -27.22 & 121.7 \\
\hline
\end{tabular}




\begin{tabular}{|c|c|c|c|c|c|}
\hline Sample type & Block Treatment & ID & Date & $\mathrm{d} 15 \mathrm{~N}$ & Molar C:N \\
\hline Sediment & 1 Ambient & $0-1 \mathrm{~cm}$ & $8 / 14 / 2013$ & $1072.82-27.20$ & 37.0 \\
\hline Sediment & 1 Ambient & $1-2 \mathrm{~cm}$ & 8/14/2013 & $217.62-27.09$ & 31.0 \\
\hline Sediment & 2 Ambient & $0-1 \mathrm{~cm}$ & $8 / 14 / 2013$ & $187.60-27.97$ & 30.2 \\
\hline Sediment & 2 Ambient & $1-2 \mathrm{~cm}$ & 8/14/2013 & $30.78-27.85$ & 31.4 \\
\hline Sediment & 3 Ambient & $0-1 \mathrm{~cm}$ & 8/14/2013 & $1245.51-27.35$ & 28.4 \\
\hline Sediment & 3 Ambient & $1-2 \mathrm{~cm}$ & 8/14/2013 & $366.25-27.44$ & 33.0 \\
\hline Sediment & 1 Ambient & $0-1 \mathrm{~cm}$ & $10 / 13 / 2013$ & $1060.63-26.85$ & 29.0 \\
\hline Sediment & 1 Ambient & $1-2 \mathrm{~cm}$ & $10 / 13 / 2013$ & $1077.19-26.63$ & 30.9 \\
\hline Sediment & 2 Ambient & $0-1 \mathrm{~cm}$ & $10 / 13 / 2013$ & $207.30-27.50$ & 31.4 \\
\hline Sediment & 2 Ambient & $0-1 \mathrm{~cm}$ & $10 / 13 / 2013$ & $265.53-27.32$ & 28.9 \\
\hline Sediment & 2 Ambient & $0-1 \mathrm{~cm}$ & $10 / 13 / 2013$ & $308.11-27.71$ & 31.1 \\
\hline Sediment & 2 Ambient & $1-2 \mathrm{~cm}$ & $10 / 13 / 2013$ & $81.20-27.32$ & 30.5 \\
\hline Sediment & 3 Ambient & $0-1 \mathrm{~cm}$ & $10 / 13 / 2013$ & $654.38-27.13$ & 27.5 \\
\hline Sediment & 3 Ambient & $1-2 \mathrm{~cm}$ & $10 / 13 / 2013$ & $374.65-27.00$ & 34.7 \\
\hline Sediment & 2 Ambient & $0-1 \mathrm{~cm}$ & $5 / 22 / 2014$ & $163.83-27.89$ & 29.8 \\
\hline Sediment & 2 Ambient & $1-2 \mathrm{~cm}$ & $5 / 22 / 2014$ & $69.01-27.53$ & 31.6 \\
\hline Sediment & 1 Fertilized & $0-1 \mathrm{~cm}$ & 8/14/2013 & $1277.25-27.32$ & 33.4 \\
\hline Sediment & 1 Fertilized & $1-2 \mathrm{~cm}$ & $8 / 14 / 2013$ & $517.29-27.41$ & 33.7 \\
\hline Sediment & 2 Fertilized & $0-1 \mathrm{~cm}$ & 8/14/2013 & $1386.55-27.51$ & 30.1 \\
\hline Sediment & 2 Fertilized & $1-2 \mathrm{~cm}$ & 8/14/2013 & $327.13-27.15$ & 34.9 \\
\hline Sediment & 1 Fertilized & $0-1 \mathrm{~cm}$ & 10/13/2013 & $304.84-27.14$ & 30.8 \\
\hline Sediment & 1 Fertilized & $1-2 \mathrm{~cm}$ & 10/13/2013 & $321.71-27.19$ & 35.7 \\
\hline Sediment & 2 Fertilized & $0-1 \mathrm{~cm}$ & $10 / 13 / 2013$ & $837.97-27.70$ & 30.1 \\
\hline Sediment & 2 Fertilized & $1-2 \mathrm{~cm}$ & $10 / 13 / 2013$ & $283.23-27.53$ & 30.4 \\
\hline Sediment & 3 Fertilized & $0-1 \mathrm{~cm}$ & $10 / 13 / 2013$ & $2331.90-27.42$ & 34.1 \\
\hline Sediment & 3 Fertilized & $1-2 \mathrm{~cm}$ & $10 / 13 / 2013$ & $1319.63-27.42$ & 41.1 \\
\hline Sediment & 2 Fertilized & $0-1 \mathrm{~cm}$ & $5 / 22 / 2014$ & $496.81-27.97$ & 29.4 \\
\hline Sediment & 2 Fertilized & $1-2 \mathrm{~cm}$ & 5/22/2014 & $288.74-27.52$ & 31.6 \\
\hline
\end{tabular}




\section{BIBLIOGRAPHY}

Adame, M.F., Zaldívar-Jimenez, A., Teutli, C., Caamal, J.P., Andueza, M.T., LópezAdame, H., Cano, R., Hernández-Arana, H.A., Torres-Lara, R., Herrera-Silveira, J.A., 2013. Drivers of mangrove litterfall within a karstic region affected by frequent hurricanes. Biotropica, 45:147-154.

Aké-Castillo, J.A., Vázquez, G. Lopez-Portillo, J., 2006. Litterfall and decomposition of Rhizophora mangle L. in a coastal lagoon in the southern Gulf of Mexico. Hydrobiologia, 559: 101-111.

Alongi, D. M., 2009. The Energetics of Mangrove Forests. Springer, New York.

Alongi D.M., Boto K.G., \& Robertson A.I., 1992. Nitrogen and phosphorus cycles. In: Robertson A.I. \& Alongi D.M. (eds) Tropical mangrove ecosystems, American Geophysical Union, Washington, DC

Arreola-Lizárraga, J.A., Flores-Verdugo, F.J. and Ortega-Rubio, A., 2004. Structure and litterfall of an arid mangrove stand on the Gulf of California, Mexico. Aquatic Botany, 79:137-143.

Ball, M.C., 1988. Ecophysiology of mangroves. Trees 2: 129-142.

Benner, R. \& R. E. Hodson, 1985. Microbial degradation of the leachable and lignocellulosic components of leaves and wood from Rhizophora mangle in a tropical mangrove swamp. Marine Ecology Progress Series 23: 221-230.

Boto, K. G. \& Wellington, J. T., 1983. Phosphorus and nitrogen nutritional status of a northern Australian mangrove forest. Marine Ecology Progress Series 11: 63-69.

Bouillon, S., 2011. Storage beneath mangroves. Nature Geoscience 4: 282-283 
Bouillon, S., Dahdouh-Guebas, F., Rao, A. V. V. S., Koedam, N., Dehairs, F., 2003;

Sources of organic carbon in mangrove sediments: variability and possible ecological implications. Hydrobiologia 495: 33-39.

Bouillon, S., Connolly, R. M., Lee, S. Y., 2008. Organic matter exchange and cycling in mangrove ecosystems: Recent insights from stable isotope studies. Journal of Sea Research 59: 44-58.

Bowen, J. L., Valiela, I., 2008. Using $\delta^{15} \mathrm{~N}$ to assess coupling between watersheds and estuaries in temperate and tropical regions. Journal of Coastal Research 24: 804813.

Capella, J., 2008. Environmental setting. In: Field, R. (ed.) Jobos Bay Estuarine Profile. Revised June 2008 by Angel Dieppa. Jobos Bay National Estuarine Research Reserve. https://coast.noaa.gov/data/docs/nerrs/Reserves_JOB_SiteProfile.pdf. Last accessed December, 2015.

Cebrián J., M. Williams, J. McClelland, \& I. Valiela, 1998. Ecology Letters 1: 165-170.

Chale, F. M. M., 1993. Degradation of mangrove leaf litter under aerobic conditions. Hydrobiologia 257: 177-183.

Chen, R., \& Twilley, R. R., 1999. Patterns of mangrove forest structure and soil nutrient dynamics along the Shark River estuary, Florida. Estuaries, 22: 955-970.

Clough, B.F., Dixon, P., Dalhaus, O., 1997. Allometric relationships for estimating biomass in multi-stemmed mangrove trees. Australian Journal of Botany, 45: 1023-1031.

Corredor, J. E., \& Morell, J. M., 1994. Nitrate depuration of secondary sewage effluents in mangrove sediments. Estuaries, 17: 295-300. 
Corredor, J. E., Howarth, R. W., Twilley, R. R., Morell, J. M., 1999. Nitrogen cycling and anthropogenic impact in the tropical interamerican seas. Biogeochemistry 46: 163-178.

Corstanje, R., Reddy, K.R., Portier, K.M., 2006. Typha latifolia and Cladium jamaicense litter decay in response to exogenous nutrient enrichment. Aquatic Botany, 84: 70-78.

Craine, J. M., C. Morrow, \& N. Fierer, 2007. Microbial nitrogen limitation increases decomposition. Ecology 88: 2105-2113.

Davis, S. E., C. Corronado-Molina, D. L. Childers, \& J. W. Day, 2003. Temporally dependent $\mathrm{C}, \mathrm{N}$, and P dynamics associated with the decay of Rhizophora mangle L. leaf litter in oligotrophic mangrove wetlands of the Southern Everglades. Aquatic Botany 75 199-215.

Darby, F.A. Turner, R. E., 2008. Below- and aboveground biomass of Spartina alterniflora: response to nutrient addition in a Louisiana salt marsh. Estuaries and Coasts 31: 326-334

Das, S. \& J. R. Vincent, 2009. Mangroves protected villages and reduced death toll during Indian super cyclone. Proceedings of the National Academy of Sciences of the United States of America. 106: 7357-7360.

Day, J.W., Conner, W.H., Ley-Lou, F., Day, R.H., Navarro, A.M., 1987. The productivity and composition of mangrove forests, Laguna de Terminos, Mexico. Aquatic Botany, 27, 267-284.

Day, J.W., Coronado-Molina, C., Vera-Herrera, F.R., Twilley, R., Rivera-Monroy, V.H., Alvarez-Guillen, H., Day, R., Conner, W., 1996. A 7 year record of above-ground 
net primary production in a southeastern Mexican mangrove forest. Aquatic Botany, 55: 39-60.

Debusk, W. F. \& K. R. Reddy, 2005. Litter decomposition and nutrient dynamics in a phosphorus enriched everglades marsh. Biogeochemistry 75: 217-240.

Deegan, L.A., Bowen, J.L., Drake, D., Fleeger, J.W., Friedrichs, C.T., Galvan, K.A., Hobbie, J.E., Hopkinson, C., Johnson, D.S., Johnson, J.M., LeMay, L.E., 2007. Susceptibility of salt marshes to nutrient enrichment and predator removal. Ecological Applications, 17, S42-S63.

Deegan, L. A., Johnson, D. S., Warren, R. S., Peterson, B. J., Fleeger, J. W., Fagherazzi, S., Wollheim, W. M., 2012. Coastal eutrophication as a driver of salt marsh loss. Nature 490: 388-392.

Donato, D. C., Kauffman, J. B., Murdiyarso, D., Kurnianto, S., Stidham, M., Kanninen, M., 2011. Mangroves among the most carbon-rich forests in the tropics. Nature Geoscience 4: 293-297.

Downing, J. A., McClain, M., Twilley, R., Melack, J. M., Elser, J., Rabalais, N. N., Lewis, W.M., Turner, R. E., Corredor, J., Soto, D., Yanez-Arancibia, A., Kopaska, J. A., Howarth, R. W., 1999. The impact of accelerating land-use change on the $\mathrm{N}$-cycle of tropical aquatic ecosystems: Current conditions and projected changes. Biogeochemistry 46: 109-148.

Drake, D. C., Peterson, B. J., Deegan, L. A., Harris, L. A., Miller, E. E., \& Warren, R. S., 2008. Plant nitrogen dynamics in fertilized and natural New England salt marshes: a paired 15N tracer study. Marine Ecology Progress Series 354: 35-46. 
Ewel, J. J., Whitmore, J. L., 1973. The Ecological Life Zones of Puerto Rico and the U. S. Virgin Islands. Forest Service Research Paper ITF-18.

Faithful, J. W., J. Brodie, A. Hooper, P. Leahy, G. Henry, W. Finlayson \& D. Green, 2007. Plot-scale runoff of nutrients and sediment under varying management regimes on a banana and cane farm in the wet tropics, Queensland. Australian Centre for Tropical Freshwater Research, Report No. 07/10.

Feller, I. C., 1995. Effects of nutrient enrichment on growth and herbivory of dwarf red mangrove (Rhizophora mangle). Ecological Monographs 65: 477-505.

Feller, I. C., Whigham, D. F., O'Neill, J. P., \& McKee, K. L., 1999. Effects of nutrient enrichment on within-stand cycling in a mangrove forest. Ecology, 80: 21932205.

Feller, I. C., Whigham, D. F., McKee, K. L., Lovelock, C. E., 2003. Nitrogen limitation of growth and nutrient dynamics in a disturbed mangrove forest, Indian River Lagoon, Florida. Oecologia 134: 405-414.

Feller I. C., C. E. Lovelock, C. Piou, 2009. Growth and Nutrient Conservation in Rhizophora mangle in response to fertilization along latitudinal and tidal gradients. Smithsonian Contribution to the Marine Sciences. 38: 345-358.

Field, R. M., 2008. Introduction and Summary. In: Field, R. (ed.) Jobos Bay Estuarine Profile. Revised June 2008 by Angel Dieppa. Jobos Bay National Estuarine Research Reserve. https://coast.noaa.gov/data/docs/nerrs/Reserves_JOB_SiteProfile.pdf. Last accessed December, 2015.

Hopkinson, C. S., Day, J. W., 1980. Modeling the relationship between development and storm water and nutrient runoff. Environmental Management 4: 315-324. 
Holguin, G., P. Vazquez, Y. Bashan, 2001. The role of sediment microorganisms in the productivity, conservation, and rehabilitation of mangrove ecosystems: an overview. Biology and Fertility of Soils 33: 265-278.

Howarth, R. W. 2008. Coastal nitrogen pollution: A review of sources and trends globally and regionally. Harmful Algae 8: 14-20.

Howarth, R. W. \& R. Marino, 2006. Nitrogen as the limiting nutrient for eutrophication in coastal marine ecosystems: Evolving views over three decades. Limnology and Oceanography 51: 364-376.

Howarth, R.W., Billen, G., Swaney, D., Townsend, A., Jaworski, N., Lajtha, K., Downing, J.A., Elmgren, R., Caraco, N., Jordan, T., Berendse, F., 1996. Regional nitrogen budgets and riverine N \& P fluxes for the drainages to the North Atlantic Ocean: Natural and human influences. In: Howarth, R. W. (ed.) Nitrogen Cycling in the North Atlantic Ocean and its Watersheds (pp. 75-139). Springer Netherlands.

IFIA 2015. International Fertilizer Industry Association. http://ifadata.fertilizer.org/ucSearch.aspx Last accessed: September 2015.

Karberg, N. J., N. A. Scott, \& C. P. Giardina, 2008. Methods for estimating litter decomposition. In Hoover, C. M. (ed.) Field Measurements for Forest Carbon Monitoring, Springer, New York: 103-111.

Kauffman, J. B., Heider, C., Cole, T. G., Dwire, K. A., Donato, D. C., 2011. Ecosystem carbon stocks of Micronesian mangrove forests. Wetlands 31: 343-352. 
Keuskamp, J. A., H. Schmitt, H. J. Laanbroek, J. T. A. Verhoeven, \& M. M. Hefting, 2012. Nutrient amendment does not increase mineralisation of sequestered carbon during incubation of a nitrogen limited mangrove soil. Soil Biology \& Biochemistry 57: 822-829.

Keuskamp, J. A., M. M. Hefting, B. J. J. Dingemans, J. T. A. Verhoeven, \& I. C. Feller, 2015(a). Effects of nutrient enrichment on mangrove leaf litter decomposition. Science of the Total Environment 508: 402-410.

Keuskamp, J. A., I. C. Feller, H. J. Laanbroek, J. T. A. Verhoeven, \& M. M. Hefting, 2015(b). Short- and long-term effects of nutrient enrichment on microbial exoenzyme activity in mangrove peat. Soil Biology \& Biochemistry 81: 38-47.

Killingbeck, K. T., 1996. Nutrients in senesced leaves: Keys to the search for potential resorption and resorption proficiency. Ecology 77: 1716-1727.

Knorr, M., S. D. Frey, \& P. S. Curtis, 2005. Nitrogen additions and litter decomposition: A meta-analysis. Ecology 86: 3252-3257.

Komiyama, A., Ong, J. E., Poungparn, S., 2008. Allometry, biomass, and productivity of mangrove forests: A review. Aquatic Botany 89: 128-137.

Kraus et al., 2003. Tannins in nutrient dynamics of forest ecosystems - a review. Plant and Soil 256: 41-66.

Kristensen, E., Bouillon, S., Dittmar, T., Marchand, C., 2008. Organic carbon dynamics in mangrove ecosystems: A review. Aquatic Botany 89: 201-219.

Kristensen, E., Flindt, M.R., Ulomi, S., Borges, A.V., Abril, G., Bouillon, S., 2008. Emission of $\mathrm{CO}_{2}$ and $\mathrm{CH}_{4}$ to the atmosphere by sediments and open waters in two Tanzanian mangrove forests. Marine Ecology Progress Series, 370: 53-67. 
Kristensen, E., Mangion, P., Tang, M., Flindt, M.R., Holmer, M. and Ulomi, S., 2011. Microbial carbon oxidation rates and pathways in sediments of two Tanzanian mangrove forests. Biogeochemistry, 103: 143-158.

Kuzyakov, Y., 2002. Separating microbial respiration of exudates from root respiration in non-sterile soils: a comparison of four methods. Soil Biology and Biochemistry, 34(11), pp.1621-1631.

Lovelock, C.E., 2008. Soil respiration and belowground carbon allocation in mangrove forests. Ecosystems, 11: 342-354.

Lovelock, C.E., Feller, I.C., Ball, M.C., Engelbrecht, B.M., Ewe, M.L., 2006. Differences in plant function in phosphorus-and nitrogen-limited mangrove ecosystems. New Phytologist, 172, 514-522.

Lovelock, C.E., Ruess, R.W., Feller, I.C., 2006. Fine root respiration in the mangrove Rhizophora mangle over variation in forest stature and nutrient availability. Tree physiology, 26: 1601-1606.

Lovelock, C. E., Ball, M. C., Martin, K. C., Feller, I., C., 2009. Nutrient enrichment increases mortality of mangroves. PLoS ONE 4, e5600. doi:10.1371/journal.pone.0005600.

Lugo, A. E., Snedaker, S. C., 1976. The ecology of mangroves. Annual Review of Ecology and Systematics, 39-64.

Mackey, A. P., and G. Smail, 1996. The decomposition of mangrove litter in a subtropical mangrove forest. Hydrobiologia 332: 93-98. 
Martinuzzi, S., Gould, W. A., Lugo, A. E., Medina, E., 2009. Conversion and recovery of Puerto Rican mangroves: 200 years of change. Forest Ecology and Management 257, 75-84.

McKee, K. L., D. R. Cahoon, \& I. C. Feller, 2007. Caribbean mangroves adjust to rising sea level through biotic controls on change in soil elevation. Global Ecology and Biogeography 1-12.

Middleton, B. A. \& K.L. McKee, 2001. Degradation of mangrove tissues and implications for peat formation in Belizean island forests. Journal of Ecology. 89: 818-828.

Morell, J. M., \& Corredor, J. E., 1993. Sediment nitrogen trapping in a mangrove lagoon. Estuarine, Coastal and Shelf Science, 37: 203-212.

Mumby, P. J., A. J. Edwards, J. E. Arias-Gonzalez, K. C. Lindeman, P. G. Blackwell, A. Gall, M. I. Gorczynska, A. R. Harborne, C. L. Pescod, H. Renken, C. C. C. Wabnitz, G. Llewellyn, 2004. Mangroves enhance the biomass of coral reef fish communities in the Caribbean. Nature 427: 533-536.

Naidoo, G. (2009). Differential effects of nitrogen and phosphorus enrichment on growth of dwarf Avicennia marina mangroves. Aquatic Botany, 90: 184-190.

Nadelhoffer, K. J., Downs, M. R., \& Fry, B., 1999. Sinks for 15N-enriched additions to an oak forest and a red pine plantation. Ecological Applications, 9: 72-86.

Nedwell, D. B., Blackburn, T.H., \& Wiebe, W.J., 1994. Dynamic nature of the turnover of organic carbon, nitrogen and sulphur in the sediments of a Jamaican mangrove forest. Marine Ecology Progress Series, 110: 223-231. 
NERRS, 2015. NOAA National Estuarine Research Reserve System (NERRS). Systemwide Monitoring Program. Data accessed from the NOAA NERRS Centralized Data Management Office website: http://www.nerrsdata.org/. Last accessed September, 2015.

Nixon, S.W. and Fulweiler, R. W., 2009. Nutrient pollution, eutrophication, and the degradation of coastal marine systems. In: Duarte, C.M. (ed). Global Loss of Coastal Habitats. Fundacion BBVA, Bilbao, Spain. 175 pp.

Nixon, S. W., B. A. Buckley, S. L. Granger, M. Entsua-Mensah, O. Ansa-Asare, M. J. White, R. A. McKinney \& E. Mensah, 2007. Anthropogenic enrichment and nutrients in some tropical lagoons of Ghana, West Africa. Ecological Applications 17: S144-S164.

NERRS, 2015. NOAA National Estuarine Research Reserve System (NERRS). Systemwide Monitoring Program. Data accessed from the NOAA NERRS Centralized Data Management Office website: http://www.nerrsdata.org/;. Last accessed September, 2015

NOAA-NERR, 2015. http://nerrs.noaa.gov/reserves/jobos-bay.html Last accessed March, 2016.

Odum, W. E. \& E. J. Heald, 1975. Mangrove forests and aquatic productivity. In Hasler, A. D. (ed.) Coupling of Land and Water Systems. Springer, New York: 129-136.

Onuf, C. P., Teal, J. M., Valiela, I.,1977. Interactions of nutrients, plant growth and herbivory in a mangrove ecosystem. Ecology 58, 514-526. 
Ortiz-Zayas, J. R., Cuevas, E., Mayol-Bracero, O. L., Donoso, L., Trebs, I., FigueroaNieves, D., McDowell, W. H., 2006. Urban influences on the nitrogen cycle in Puerto Rico. Biogeochemistry 79, 109-133.

Pendleton, L., Donato, D.C., Murray, B.C., Crooks, S., Jenkins, W.A., Sifleet, S., Craft, C., Fourqurean, J.W., Kauffman, J.B., Marbà, N. and Megonigal, P., 2012. Estimating global "blue carbon" emissions from conversion and degradation of vegetated coastal ecosystems. PloS one, 7, e43542. DOI: 10.1371/journal.pone.0043542

Pool, D. J., Lugo, A. E., Snedaker, S. C., 1975. Litter production in mangrove forests of southern Florida and Puerto Rico. In: Walsh, G. E., Snedaker, S. C., and Teas, H. J. (ed.) Proceedings of the International Symposium on Biology and Management of Mangroves. Institute of Food and Agricultural Sciences, University of Florida, Gainesville, Florida, USA. p. 213-237.

Qiu, S., A. J. McComb, R. W. Bell, J. A. Davis, 2005. Response of soil microbial activity to temperature, moisture, and litter leaching on a wetland transect during seasonal refilling. Wetlands Ecology and Management 13: 43-54.

Rabalais, N.N., Nixon, S. W., eds. (2002). Dedicated Issue, Nutrient Over-enrichment in Coastal Waters: Global Patterns of Cause and Effect. Estuaries 25.

Reef, R., Feller, I. C., Lovelock, C. E., 2010. Nutrition of mangroves. Tree Physiology 30: $1148-1160$.

Rivera-Monroy, V. H., \& Twilley, R. R., 1996. The relative role of denitrification and immobilization in the fate of inorganic nitrogen in mangrove sediments (Terminos Lagoon, Mexico). Limnology and Oceanography, 41: 284-296. 
Robertson, A. I.,1988. Decomposition of mangrove leaf litter in tropical Australia. Journal of Experimental Marine Biology and Ecology 116: 235-247.

Robinson, C.T. \& Gessner, M.O., 2000. Nutrient addition accelerates leaf breakdown in an alpine springbrook. Oecologia, 122: 258-263.

Schindler et al. 1971. Eutrophication of lake 227, experimental lakes area, northwestern Ontario, by addition of phosphate and nitrate. Journal of the Fisheries Research Board of Canada 28, 1763-1782.

Schlesinger, W. H., E. H. DeLucia, W. D. Billings, 1989. Nutrient-use efficiency of woody plants on contrasting soils in the Western Great Basin, Nevada. Ecology 70: 105-113.

Saenger, P. and Snedaker, S.C., 1993. Pantropical trends in mangrove above-ground biomass and annual litterfall. Oecologia, 96, 293-299.

Sherman, R. E., Fahey, T. J., Martinez, P., 2003. Spatial Patterns of Biomass and Aboveground Net Primary Productivity in a Mangrove Ecosystem in the Dominican Republic. Ecosystems 6, 384-398.

Short, F.T., 1987. Effects of sediment nutrients on seagrasses: literature review and mesocosm experiment. Aquatic Botany, 27, 41-57.

Smith, T. J., Whelan, K. R. T., 2006. Development of allometric relations for three mangrove species in South Florida for use in the Greater Everglades Ecosystem restoration. Wetlands Ecology and Management 14, 409-419.

Sprent, P., 1993. Applied Nonparametric Statistical Methods. Chapman \& Hall, London. 
Steinke, T.D. and Ward, C.J., 1988. Litter production by mangroves. II. St Lucia and Richards Bay. South African Journal of Botany, 54, 445-454.

Tam, N. F. Y., \& Wong, Y. S., 1995. Mangrove soils as sinks for wastewater-borne pollutants. Hydrobiologia, 295: 231-241.

Tam N. F. Y., Wong, Y. S., Lan, C. Y., Wang, L. N., 1998. Litter production and decomposition in a subtropical mangrove swamp receiving wastewater. Journal of Experimental Marine Biology and Ecology 226: 1-18.

Turner, R.E., Howes, B.L., Teal, J.M., Milan, C.S., Swenson, E.M., Goehringer-Toner, D.D., 2009. Salt marshes and eutrophication: An unsustainable outcome. Limnology and Oceanography, 54, 1634 - 1642.

Twilley, R. R., Rivera-Monroy, V. H., 2005. Developing performance measures of mangrove wetlands using simulation models of hydrology, nutrient biogeochemistry, and community dynamics. Journal of Coastal Research 40: 79_ 93.

Twilley, R. R., Lugo, A. E., Patterson-Zucca, C., 1986. Litter production and turnover in basin mangrove forests in Southwest Florida. Ecology 67: 670-683.

Twilley, R.R., Pozo, M., Garcia, V.H., Rivera-Monroy, V.H., Zambrano, R., Bodero, A., 1997. Litter dynamics in riverine mangrove forests in the Guayas River estuary, Ecuador. Oecologia, 111: 109-122.

Valiela, I., 2006. Global Coastal Change. Blackwell Publishing, Malden, MA. 368 p.

Valiela, I., Teal, J. M., Persson, N. Y., 1976. Production and dynamics of experimentally enriched salt marsh vegetation: Belowground biomass. Limnology and Oceanography 21, 245-252 
Valiela, I., \& Cole, M. L., 2002. Comparative evidence that salt marshes and mangroves may protect seagrass meadows from land-derived nitrogen loads. Ecosystems 5: 92-102.

Vandegehuchte, M. W., Guyot, A., Hubau, M., DeGroote, S. R. E., De Baerdemaeker, N. J. J., Hayes, M., Welti, N., Lovelock, C. E., Lockington, D. A., \& Steppe, K., 2014. Long-term versus daily stem diameter variation in co-occurring mangrove species: Environmental versus ecophysiological drivers. Agricultural and Forest Meterology 192-193: 51-58.

Verhoeven, J. T., Arheimer, B., Yin, C., \& Hefting, M. M., 2006. Regional and global concerns over wetlands and water quality. Trends in Ecology \& Evolution 21: 96103.

Vitousek, P. M.,1984. Litterfall, nutrient cycling, and nutrient limitation in tropical forests. Ecology, 65: 285-298.

Whigham, D. F., Verhoeven, J. T. A., Samarkin, V., Megonigal, P. J., 2009. Responses of Avicennia germinans (black mangrove) and the soil microbial community to nitrogen addition in a hypersaline wetland. Estuaries and Coasts 32:926-936.

Wigand, C., P. Brennan, M. Stolt, M. Holt, \& S. Ryba, 2009. Soil respiration rates in coastal marshes subject to increasing watershed nitrogen loads in southern New England, USA. Wetlands 29: 952-963.

Woodroffe, C.D., 1982. Litter production and decomposition in the New Zealand mangrove, Avicennia marina var. resinifera. New Zealand Journal of Marine and Freshwater Research 16: 179-188. 
Woodroffe, C.D., Bardsley, K.N., Ward, P.J. and Hanley, J.R., 1988. Production of mangrove litter in a macrotidal embayment, Darwin Harbour, NT, Australia. Estuarine, Coastal and Shelf Science 26: 581-598.

Zitello, A. G., Whitall, D. R., Dieppa, A., Christensen, J. D., Monaco, M. E., Rohmann, S. O., 2008. Characterizing Jobos Bay, Puerto Rico: A watershed modeling analysis and monitoring plan. NOAA Technical Memorandum NOS NCCOS 76. $81 \mathrm{pp}$. 